University of Nebraska - Lincoln

DigitalCommons@University of Nebraska - Lincoln

Digitized Afghanistan Materials in English from

the Arthur Paul Afghanistan Collection

Afghanistan: The Arthur Paul Afghanistan Collection at the University of Nebraska-Omaha

3-17-2009

\title{
An account of the kingdom of Caubul, and its dependencies, in Persia, Tartary, and India (1842)
}

Mountstuart Elphinstone

Follow this and additional works at: https://digitalcommons.unl.edu/afghanenglish

Part of the Asian Studies Commons

Elphinstone, Mountstuart, "An account of the kingdom of Caubul, and its dependencies, in Persia, Tartary, and India (1842)" (2009). Digitized Afghanistan Materials in English from the Arthur Paul Afghanistan Collection. 157.

https://digitalcommons.unl.edu/afghanenglish/157

This Article is brought to you for free and open access by the Afghanistan: The Arthur Paul Afghanistan Collection at the University of Nebraska-Omaha at DigitalCommons@University of Nebraska - Lincoln. It has been accepted for inclusion in Digitized Afghanistan Materials in English from the Arthur Paul Afghanistan Collection by an authorized administrator of DigitalCommons@University of Nebraska - Lincoln. 


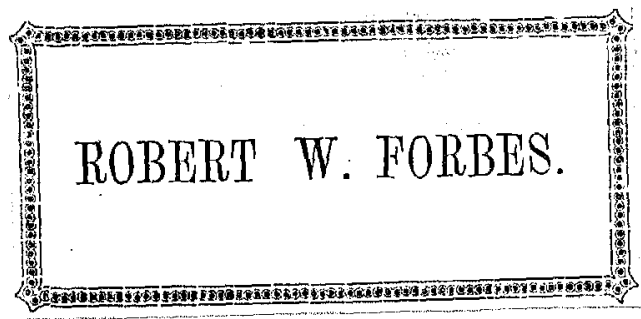

$\sqrt{ } n$ 
<smiles>C1CCCC1</smiles> 


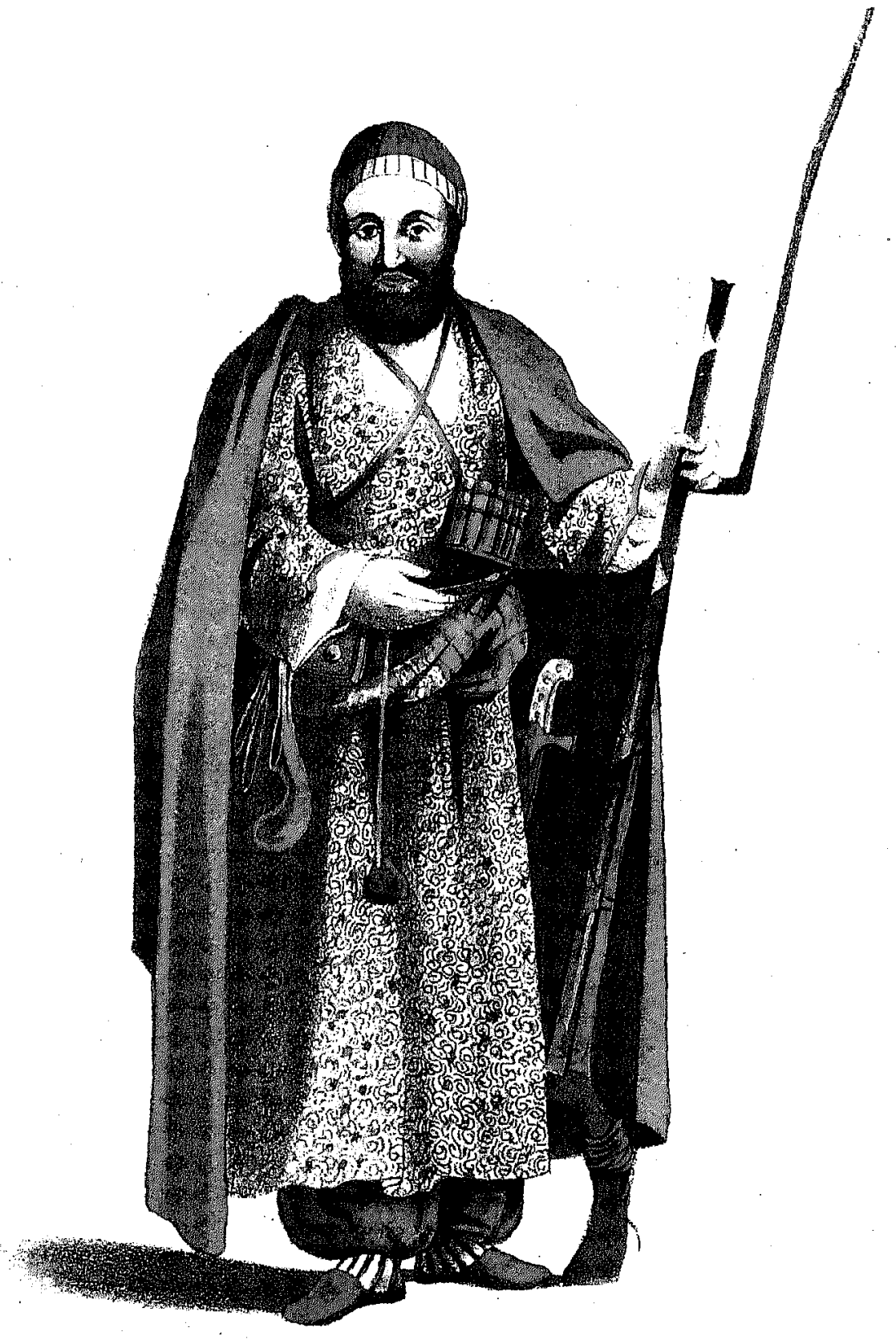

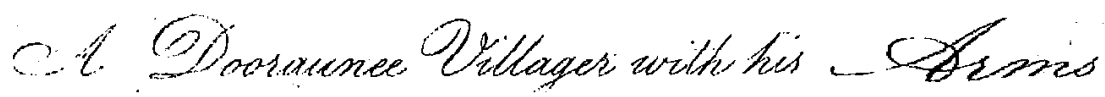

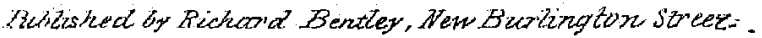

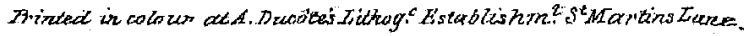




\section{AN ACCOUNT}

$$
\text { op Tria }
$$

\section{KINGDOM OF CAUBUL,}

AND ITS DEPENDENCIES,

IN PERSIA, TARTARY, AND INDIA;

COMPRISING

A VIEW OF THE AFGHAUN NATION, AND

A HISTORY OF THE DOORAUNEE MONARCHY.

BY TIIE

HON. MOUNTSTUART ELPHINSTONE.

NEW AND REVISED EDITION.

IN TWO VOLUMES.

VOL. II.

\section{LONDON:}

RICHARD BENTLEY, NEW BURLINGTON STREET,

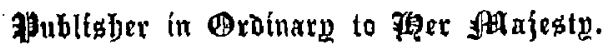





\section{CONTEN'TS}

OF THE SECOND VOLUME.

\section{BOOK III.}

\section{CHAPTER I.}

PARTICULAR ACCOUNT OF THE AFGHAUN TRIBES.

Eastern tribes.-The Berdooraunees.-Extent and boundaries.General character of the people.-Goondees or associations.-Description of the Berdooraunee country. . . . Page I

EUSOFZYES.

Description of their country.-Valley of Chumla.-Valley of Swaut. - Boonerre.-The Judoons of Dumtour.- History of the Eusofzyes.Their emigration from Khorassaun, and settlement in their present seats.-Manners in former days.-Division of the lands of the tribe. Singular custom of Waish, or interchange of lands. Anarchy of the Eusofzyes.-Form of government in a Eusofzye Oolooss.-Detailed account of the distractions in a Eusofzye clan.-Account of a particular feud.-Effects of this anarchy.-Wars between Ooloosses.-Varieties in the governments of Eusofzye Ooloosses.-Despotism established by Kaussim Khaun of Deer. - Numbers of the Eusofzyes.Condition of the Fakeers or Villains.-Artizans attached to a division of an Oolooss.-Customs levied by Ooloosses.-Houses, food, dress, and manners of the Eusofzyes.-Their character . . 9

TURCOLAUNEES.

Description of Bajour.-Description and numbers of the inhabitants. -Government of the Turcolaunees.-Manners and character . 35 a 2 
OTMAUNKHAIL.

Face of the country.-Govelnment, manners, and character of the people.-Number's - Page 38 upper momunds.

Face of the country.-Currapa pass.-Numbers.-Government.Employment of the population .

KHYBEREES.

Face of the country.-Divisions and numbers of the Khyberees.Khyber pass.-Pensions for securing it.-Depredations.-Appearance, manners, and character

TRIBES OF PISHAWER.

Face of the country.-Divisions and numbers.-History of the Glioreeakhail.-Dependence on the King.-Internal government, dress, manners, and character . . . . . . 45

RHUTTUKS.

Numbers.-Face of the country.-Plains on the north.-Divisions and numbers.-Government and character.-Mountains in the south. Baurilss

BUNGUSHES AND OTHER TRIBES,

Face of the country of the Bungushes.-Government and character. -Toorees.-Jaujees.-Esaukhail.—Sheotuk. - Bunnoo. - Dour.Khost.-Tunnees in Drugye.-Vizeerees . . . 50

\section{CHAPTER II.}

\section{EASTERN TRIBES CONIINUED.-TRIBLS OF DAMAUN.}

Limits.-Divisions.-Tribe of Murwut.-Damaun Proper and its divisions.-Country of the tribes of Gundehpoor and Dowlutkhail.Country of the Meeaunkhail, Bauboors, and Stooreeaunees.-Produce of Damaun.-General character of the tribes of Damaun.-Remarkable temporiury magistracy of the Chelwushtee or Dictator . 55 . 
DOWLUTKHAIL.

Establishment of despotism in a free tribe illustrated by the history of the Dowlutkhail.-Usurpation of Kuttaul.-His deatl..-Successful usurpation of his son Surwur.-Gundehpoors.-Meeaunklail.Bulkhteeaurees, a Persian tribe, united with the Meeaunklaail.Bauboors.-Stooreeaunees.-Forsake pasturage for tillage.-General confederacies of all the tribes. - Famous tribes of Soor and Lodi. Damaun much frequented by pastoral hordes . . . 62

\section{CHAPTER III.}

MOUNTAIN TRIBES,-ZMURRETS.- SHEERAUNEES.

Face of the country.-Dress, manners, and habits of the people.Peculiar government, founded partly on respect for birth, and partly on superstition.-Chelwushtees.-Moollahs.-Predatory character of the Sheeraunees.-Their wars.-Countries west of the Sheernunees. -Murhails of Spusta.-Tribes of Kuppeep and Hureepaul . 73

VIZREREES,

Face of the country.-Predatory chruacter of the people.-Manners and habits of life.-Peculiar custom relating to marriage. - The Jadrauns.-Countries west of the Vizeerees, \&c.-Dumtaunees of Waunel1

\section{CHAPTER IV.}

WESTERN AFGHAUNS, DOORAUNEES, CITY OF CANDAHAR, TERENNS, AND BARAICHIS.

General description.-Impression made on the western tribes by the monarchy.-Pastoral tribes . . . . . . 84

DOORAUNEES.

Extent and boundaries.-Description of the country (in five divisions).-1 st. That west of long. $63^{\circ}$ east.-2nd. That from long. $63^{\circ}$ east to the meridian of Candahar.- 3 rd. That in the hills south of the Paropamisan range.-4th. That round Candahar.-5th. That in the 
south-east of the Dooraunee country.-Animals in the Dooraunee country.-Name and early history of the Dooraunees.-Divisions.Populzyes. -Baurikzyes. - Atchikzyes.-Alizyes. - Allekkozyes.Iskhaukhzyes.-Maukoos and Khougaunees.-Population of the Dooraunee country. - Internal government of the tribe.-The King Chief.-Favourable effect of the competition between the crown and the nobles. - Internal government of each clan.-Agricultural Dooraunees.-Form of villages. - Houses and furniture.--Shops.-Public apartment.-Employments.-Castles of petty Kbauns.-Character of that class.-Humsauyehs or Denizens.-Pastoral Dooraunees.-Description of a black tent.-Camps.- Shepherds in scattered tents. Charms of the pastoral life.-Way of life of the shepherds of Toba.Composition of a camp.- Employments of the people.-Dress of the Dooraunees. Food.-Appearance.-Manners and condition.-Hospitality.-Character.-Esteemed by the other tribes.-Account of the clan of Atchikzyes.-Account of Candahar . . . 88

BAIAICHES.

Deseription of Shoraubuk. - Camels used to ride on and to plough. -Cooddools or houses of hurdles . . . . . . . 134

TEREENS.

Division into white and black.-Description of Pisheen.-Syuds of Pisheen.-Speen or white Tereens in Tull and Chooteeallee . 136

CHAP'TER V.

GHILJIES, CITIFS OF GHUZNEE AND CAUBUL, WURDUKS AND CAUKFR.

GHILJIES.

Boundaries.-Description of the country. - Valley of the Turnuk. - Tract under the Paropamisan hills. Tract south of the valley of the Turnuk.-Tract south of latitude 320.-Mummye.-Bason of the Aubistaudeh. - City of Ghuznee.-Ghiljie country under the range of Solimaun.-City of Caubul.-Divisions of the tribe of Ghiljie.-Hotukees.-Tokhees. -Turrukees.-Unders. - Kharotees, - Alikhails. -Solimaunkhails.-Suhauks.-Sheerpaws.-Difference between the eastern and western Ghiljies,-Government of the tribe.-Former power of the Ghiljie Kings.- Loose government at present.-Example 
of the Kulunderkhail, a clan of the southern Solimaunkhail.-Manners.-The Ahmedzyes.-Character of the Ghiljies.-Particular account of the Kharotees.-Mountains.-Valleys.-Produce.-Government.-Birth little regarded.-Employment.-The pastoral Kharotees, how led to that mode of life . . . Page 137

CAUKERs.

Boundaries.-Face of the country.-Burshore.-Shawl.-Punnees in Seewee.-Tribe of Lonee.-Zawura.-Tull and Chooteeallee.Boree.-Zhobe.-Divisions of the tribe of Caulser.-Account of a clan of the western Caukers.-Government.-Destruction of a Beloche army by Tahmas Khaun of Dozhulkh.-Powers of the Khaun of the clan of Sunnateea.-Manners.-Eastern Caukers exemplified by an account of Boree.-Other Caukers . . . . 162

\section{CHAPTER VI.}

NAUSSERS.

The Naussers have no country.-Wandering life.-Detailed account of their marches.-Battles with the Vizeerees.-Life in Damaun. Employment.-Manners.-Causes of their enjoying a free government, though a pastoral tribe

\section{BOOK IV.}

THE PROVINCES.

CHAPTER I.

DULKH, OR BACTRIA AND THE UZBEKS

CHAPTER II. 
. CHAPTER III.

HERAUT

Page 215

CHAPTER IV.

SEES'MUN

CHAPTER V.

BLLOCHISTAUN AND LOWER SIND.

. 223

CHAPTER VI.

UPIER SIND, MOULTAUN, LEIA, AND THE COUNTHIES BETWEEN LEIA AND CASHMER

CHAPTER VII.

CASHMEER.

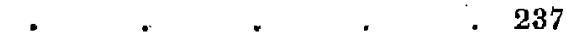

\section{BOOK V.}

THE ROYAL GOVERNMENT OF CAUBUL.

\section{GHAPTER I.}

OF THE KING.

Succession to the crown.-Royal Family. - King's title.-His powers.-Domestic and foreign policy of the government of Caubul. -Its character.-Present state. . . . . 243

\section{CHAPTER II.}

ADMINISTRATION OF THE GOVERNMENT.

The Vizeel-The other ministers. - The houselold .

$\therefore 251$ 
CHAPTER III.

OF THE DIVISION OF THE KINGDOM INTO PROVINCES .

255

CHAPTER IV.

OF THE REVENUE

CHAPTER V.

JUSTICE AND POLICE OF THE KINGDOM - 262

CHAPTER VI:

THE MILITARY ESTABLIBHMENT.

Dooraunees.-Gholaums, or King's guards.-Karra Nokur.-Eeljauree.-Dawatullub, or volunteers. - Principal military officers.Arms and Equipment.-Discipline and mode of war.-Civil wars

. 266

CHAPTER VII.

THE REIIGIOUS ESTABLISEMENT

- 277

\section{APPENDIX A.}

HISTORY OF THE KINGDOM OF CAUBUL FROM THE FOUNDATION OF THE DOORAUNEE MONARCHY.

AHMED SHAUH.

Early history of the Dooraunees.-Ahmed Shauh assumes the crown.-Form of his government, and its policy, internal and external.-Ahmed Shaul takes Ghuznee, Caubul, and Peshawer.- 
Abmed Shaul's first expedition to India.-Defeated at Sirhind.-The Punjaub annexed to the Dooraunee monarchy.-Ahmed's first expedition to Persian Khorassaun.-Second expedition to Persian Khorassaun, reduction of the province.-Second expedition to India: conquest of Cashmeer.-Third expedition to India : capture of Dehli.Mahratta war.-Revolt of Nusseer Khaun, chief of the Beloches.Suppressed.-State of the Punjaub.-Fourtl expedition to India.Second capture of Dehli.-Battle of Panniput.-Fifth expedition to India. - Sixtl and last expedition to India.-Third expedition to Persian Khorassaun.-Death and Character of Ahmed Shauh.-His policy towards the different classes of his subjects . Page 279

TIMOUR SHAUH.

Fruitless plots to oppose the accession of Timour Shauh.-Timour Shauh's system of government.-Insurrections.-Conspiracy of Feizoollah Khaun.-Expedition to the Moultaun.-War with the King of Bolkhaura.-Death of Timour Shauh . . . 300

\section{SHAUH ZEMAUN}

Accession of Shauh Zemaun.-Opposed by Prince Hoomayoon.Prince Hoomayoon defeated.-Bulkh invaded by the Uzbeks.-Troubles in other parts of the country.-Rebellion of Prince Mahmood.Troubles in Belochistaun.-Defeat and seizure of Prince Hoomayoon. -Character and projects of Shauh Zemaun.-Power of the Vizeer Wuffadar Khaun.-His character.-Shauh Zemaun sets out to invade the Punjaub.-Khorassaun invaded by the King of Persia.-Shaulı Zemaun invades the Punjaub.-Alarm throughout India.-Rebellion of Prince Mahmood.-Second invasion of the Punjaub.-Attempt on Heraut by Mahmood.-Flight of Mahmood to Bokhaura.-Shauh Mahmood joined by Futteh Khaun.-Enters the Afglaun dominions. -Talses Candahar.-Misconduct of Shauh Zemaun.-His flight.Shauh Zemaun betrayed.-Blinded and imprisoned . . 308

\section{SFAUH MAHMOOD.}

Joy of the people on the accession of Mahmood.-Disorders of Mahmood's government.--Prince Shujah proclaimed King at Peshawer.-Defeated.-Ghiljie rebellion.-Danger of the Dooraunee monarchy.-Second rising of the Ghiljies.-Final suppression of the Ghiljie rebellion.-Second defeat of Prince Shujah.-Weakness of the government.-Conquest of Persian Khorassaun by the Persians,- 
Discontent of the people.-Character of Mookhtaur Ooodowlah, and of the Meer Waez,-Battle between the Sheealss and Soonnees.Mahmood deposed

- Page 325

\section{SHAUH SHUJAH.}

Reduced state of the power of the crown.-Wise measures of the new government.-Rebellion of Prince Kyser.-Intrigues of Futteh Khaun.-Dissensions between the King and the Vizeer Mookhtaur Oodowlah. The vizeer's expedition to reduce Cashmeer.-Intrigues and commotions excited by Futteh Khaun.-Attack on Heraut by the Persians.-Increased dissension between the King and the vizeer. -Escape of Shauh Mahmood.-Rebellion of the vizeer.-Defeat and deatl of the vizeer.-Mahmood and Futteh Khaun take Candahar.Are defeated

\section{APPENDIX B.}

MR. DURIE'S NARRATIVE

\section{APPENDIX C.}

ACCOUNT OF SOME NEIGHBOURING COUNTRIRE.

Caufiristaun.-Budukhshaun.-Kaushkaur . . 373

\section{APPENDIX D.}

EXTRACT FROM LIEUTENANT MACARTNEY'S MEMOIR.

Construction of the map.-Face of the country.-Hindoo Koosh, or Great Snowy Ridge.-Pamer Ridge.-Budukshaun Ridge.-_Teera, or Khyber Range.-Sohmaun Ridge.-Groups of hills extending easiward from the Solimaun Ridge down towards the Indus.Groups of hills extending westward from the Solimaun Ridge.Kohistaun, north of the Caubul river.-Ranges of hills east of the Indus.-Table land of Little Tibet and the hills extending northwest to Yarkund.-Rivers. - The river Ammu, or Oxus.-The Kokcha, or Budukhshaun river.-The Aksurrai.-The Hissar, or Kafimihan river.-The Zurufshan.-The Murghab river.-The river 
Sirr.-The river Sind, or Indus.-The Abba Seen.-The Kama river.-The Ghur Sheen.-The Swan river.-The Koorm river.The Jelum, Behut, or Vidusta (Hydaspes).-The Chunab (Acesines). - The Ravee (Hydraotes). - The Beyah, or Beyas (Hyphasis).The rivers of Khorassaun. - The Hirmund, or Helbund. - The Urghundab river.-The Khashrood.-The Turnuk,-The Furrahrood.-The Poolimalan, or Hirat river

\section{APPENDIX E.}




\section{A C COUN T}

OF THE

\section{KINGDOM OF CAUBUL.}

\section{BOOK III.}

PARTICULAR ACCOUNT OF THE AFGHAUN TRIBES,

\section{CHAPTER I.}

EASTERN TRIBES.- -THE BERDOORAUNEES.

I Now proceed to a particular description of the tribes, among which so great a diversity will be observed, that it is necessary to remind the reader, that they are all of the same race, speak the same language, and form one nation.

All the preceding account applies to every tribe, unless where it has been limited at the time, or where it is contradicted in the following description.

I shall begin with an account of the Berdooraunees, and among them of the tribe of Eusofzye. Though the Eusofzyes afford an unfavourable specimen of the 
character and manners of the Afghauns, yet they display many of the peculiarities of their nation in more perfection than any other tribe. When the whole of their institutions have been explained, those of the other Berdooraunees may be shown as modifications of the same system, and those of the southern and western tribes may be rendered intelligible, by comparing them with this standard.

The tribes which inhabit the north-eastern part of the Afghaun country, enclosed between the range of Hindoo Coosh, the Indus, the Salt Range, and the Range of Solimaun, are comprehended in the general name of Berdooratunees, first given to them by Ahmed Shauh. They consist of the Eusofzyes, Otmaun Khail, Turcolaunees, Khyberees, the tribes of the plain of Peshawer, and those of Bungush and Khuttuk.

Before I describe each of these tribes, I shall notice the principal points in which they differ from all the other Afghauns.

It has already been mentioned, that the eastern Afghauns appear to have received their civilization from India, and this observation applies particularly to the Berdooraunees. From the early period at which the Kings of Ghuznee and Caubul obtained possession of Hindostan, the north-eastern part of Afghaumistaun has been always the thoroughfare between those empires; and the inhabitants have imitated the manners of the country where the arts of life were probably most advanced, and which was, besides, in general, the residence of the sovereign and his court. These habits were probably earliest introduced into the cities, and the tribes upon the great roads, but they have proved most permanent in the 
more retired parts of the country; the others still continued to be most frequented, after the connection with India was destroyed, and the presence of the Dooraunee court and army has introduced a disposition to adopt the language and manners of Khorassaun. On the whole, however, the manners of India, mixed with those peculiar to the Afghauns, still prevail amongst all the Berdooraunees.

The Berdooraunees are divided into numerous little societies. As they are all agricultural, they are crowded into a less space than could be occupied by any of the tribes, which are in part or entirely pastoral; and as they continue to increase, each tribe finds itself more and more straitened every day; hence arise disputes and battles about land and water, and constant jealousy of neighbouring tribes. The effects of a crowded population are also observable in individuals. Every man is obliged to pay constant attention to the means necessary for his own subsistence, and has little regard to the convenience or the rights of his neighbours. In consequence, we find the Berdooraunees brave, but quarrelsome ; active, industrious, and acute, but selfish, contentious, and dishonest. They are more bigoted and intolerant than the other Afghauns, and more under the influence of their Moollahs. They are also more vicious and debauched, and some among them are, in all respects, the worst of the Afghauns.

These characteristics are variously modified, according to the situations of the different tribes. They are less strongly marked among the scattered inhabitants of the mountains, than among those of the plains and valleys. The free tribes are most turbulent; 
those under a powerful chief most litigious. The general custom of the Afghauns also modifies the practice of the Berdooraunees. This custom, for example, makes them hospitable, though their own situation has made them selfish; but their hospitality by no means equals that of the restern tribes.

The custom of joining in associations for mutual defence, obtains among all the Berdooraunees, except the Eusofzyes. It evidently originates in the continual strife which prevails among them ; "why the Eusofzyes, who appear to require it the most, should be without it, I confess myself unable to explain; but the fact is corroborated by all the information I possess on the subject.

These confederacies have some resemblance to the Sodalitia of the Saxon times. Individuals enter into engagements to support each other, either in specific enterprises, or in all cases that may arise. These alliances are called Goondees, and they may include any number of persons. The connection between two persons in the same Goondee, is reckoned stronger than that of blood. They are bound to give up all they have, and even their lives, for each other. A Goondee between two chiefs, is not dissolved even by a war between their tribes; they may join in the battle, but as soon as the contest is over, their friendship is renewed.

Goondees also take place between tribes. The whole of the Berdooraunees, except the Eusofzyes, Otmaunkhail, Turcolaunees, and Khuttuks, were formerly united into two great confederacies, distinguished by the names of Garra and Saumil, and were bound to assist each other in all contests; but the 
alliance has relaxed of late, and the whole confederates are never now engaged in one war.

The Berdooraunees possess the hills and valleys under Hindoo Coosh, and those connected with the range of Solimaun, together with the plains of Bajour and Peshawer. The ridge of Hindoo Coosh, it will be remembered, is covered with perpetual snow; the hills beneath have bare summits, but their sides are clothed with woods of firs, oaks, walnuts, wild olives, and many other trees; and still lower, it has been observed that all the fruits and flowers of Europe grow wild. The forests on the mountains are full of wild beasts, of which tigers, leopards, wolves, bears, and hyenas are the most remarkable. The Caufirs occupy the highest of the habitable hills, and those who are near the Afghauns, have been converted to the Mahommedan religion, and pay tribute to the nearest tribe. The lower hills are frequented by Hindoo subjects of the Afghauns, who feed large herds of buffaloes and flocks of goats. The lowest hills are, however, in some cases, inhabited and cultivated by the Afghauns themselves. The sides of the valleys, when cultivated, bear wheat and barley, which depend entirely on the rain; but the bottoms are irrigated from the streams by which they are always divided, and yield all the productions of the plains. These are wheat, rice, Indian corn, barley, pulse, sugar-cane, tobacco, and cotton; but these are by no means everywhere in equal quantities. Wheat, maize, and rice are nearly equal in Peshawer, while the former preponderates in Bajour, and the latter in Swaut.

The commonest animals are oxen, which are every 
where used for tillage, and in most parts for carrying burdens. Asses and mules are also employed in carriage, but they, as well as horses, are uncommon in the valleys of Hindoo Coosh; and even sheep are rare in Bajour, Upper Swaut, and Boonere.

The climate varies from that of the snowy mountains to that of the hot plain of Peshawer. Most, even of the habitable mountains, have snow on their tops, from four to six months in the year. Of the valleys, Upper Swaut has a delightful climate, never hotter than the dog-days in England, and never very cold. Lower Swaut, being confined by hills, is hotter than Peshawer, as is Bajour in summer, for the same reason; but in winter its elevation makes it somewhat colder, and snow lies for three or four days every year.

The Eusofzyes are a very numerous tribe, divided into many little communities, chiefly under democratic constitutions. They possess the extensive country between the Otmaunkliail mountains and the Indus, Hindoo Coosh, and the river of Caubul, composed of the northern part of the plain of Peshawer, and the valleys of Punjcora, Swaut, and Boonere. They also possess Drumtour, on the eastern side of the Indus.

The Eusofzye part of the plain of Peshawer extends along the banks of the Indus, and the river of Caubul, from Torbela to Hushtnugger. The breadth of it, between the mountains on its north and the rivers, varies from two miles to ten. It is all very rich, but less so in the centre than at either extremity. Immediately to the north of this plain is a chain of mountains, beyond which is a broad valley called Cbumla, extending from Lower Swaut to the Indus, 
and bounded on the north by the mountains of Boonere.

The valley of Swaut opens on the plain above mentioned; it is divided through its whole extent by the river Lundye, which at first runs south-west from the mountains to Tootookaun Mutkunee, where the river of Punjcora joins it from the north-west. From this point, its course is southerly. The valley of the Lundye, down to its junction with the river of Punjcora, is called Upper Swaut; and below the junction it is called Lower Swaut. The upper part of Punjcora is mountainous, and thinly peopled, but the lower part of the valley, and, generally speaking, all to the south of the river, is rich and highly cultivated. Deer, the residence of the chief, is in the upper part, and contains about five hundred houses.

Upper Swaut is a valley about sixty miles long, and from ten to sixteen broad. The level ground on both sides of the river is extremely fertile.

Lower Swaut has almost all the advantages of Upper Swaut, with the addition of much greater fertility. It is equal in length to the other, but broader; and is watered by the same river, the course of which winds more, and is more favourable to irrigation.

Lower Swaut is highly peopled; and the chief place, Allahdund, is a considerable town. Swaut is divided from Boonere by steep hills, thinly inhabited by Baubees, an inconsiderable tribe of Afghauns.

Boonere is a rugged country, composed of a number of little valleys, all opening on the river Burrindoo, which runs through the centre of Boonere, and enters the Indus near Derbend, about twenty miles 
above Torbela. The banks of the Burrindoo are tolerably fertile, and produce rice; but they are not above a mile broad; some of the wider valleys also produce the better sorts of corn, but the general produce is a small grain called Ghoosht by the Afghauns, and Cungunnee by the Hindostaunees. * It all depends on rain, and much of it is grown on the slopes of the hills, which are formed into terraces one above another, and are cultivated with the hoe. The hills which bound. Boonere on the north-west, fill up the space between that valley, Hindoo Coosh, and the Indus.

The Judoons east of the Indus, possess Drumtore, or Drumtour, a narrow valley along the rivulet of Door, which runs south-west, and falls into the Indus near Torbela. The country seems to resemble Lower Swaut, though it probably is not so fertile.

The mountains are high, and on one side at least produce oaks, pines, walnuts, wild olives, and other hill trees; but none of the European fruits or flowers are found here, and every thing begins to have some resemblance to the produce of India. The trees on the plain are few. The country is well inhabited, and contains some very populous villages.

The Eusofzyes have possessed these countries for apwards of three hundred years; and though most of thern have heard that their origin is from the west, few possess any knowledge of the original residence and former fortunes of their tribe. The following account is abstracted from a history of the Eusofzyes, written in a mixture of Pushtoo and Persian, in the year 1184 of the Hejira (A.D. 1771). The ori- 
ginal history is of considerable length, and though nixed with such fables as the superstitious and romantic notions of the country suggest, it has a consistency and an appearance of truth and exactness, which would entitle it to credit, even if it were not corroborated by the Emperor Bauber, who is one of the principal actors in the events which it describes, and is besides one of the most correct bistorians in Asia.

The original seats of the Eusofzyes were about Garra and Noshky, the last of which places at least is on the borders of the Dushtee Loot, or Great Salt Desart, and now held by the Beloches under Kelauti Nusseer ; their numbers at that time must have been very inferior to what they are now; as they only formed a branch of the tribe of Khukkye ; the other branches of which were the Guggeeaunees, the Turcolaunees, and the Mahommedzyes. They were expelled from Garra and Noshky, about the end of the thirteenth or beginning of the fourteenth century of the Christian æra, and soon after settled in the neighbourhood of Caubul. Before they had been long there, they afforded their protection to Meerza Ulugh Beg, the son of Meerza Aboosaid, of the house of Timour; and were very instrumental in raising him to the throne of Caubul, which had before been held by his ancestors, but which probably was lost in consequence of the calamities which befel the house of Timour, on the death of Meerza Aboosaid.* Ulugh Beg, on his first accession, treated the Eusofzyes with the greatest distinction; he was, indeed, dependent on their assistance for the support of his throne;

* See D'Herbelot, article Abou Said. 
but the turbulent independence of the Fusofzyes was not suited to an intimate connection with a sovereign, and their insolence increasing with their prosperity, they insulted Ulugh Beg's authority, plundered his villages, and even filled his capital with tumult and confusion. Ulugh Beg, whose power was now strengthened by the accession of many Moguls, who flocked to his standard, resolved to rid himself of his troublesome allies; he began by fomenting dissensions between the Eusofzyes and Guggeeaunees (for the Khukkyes had now broken into independent clans), and soon after attacked them at the head of that tribe and his own army. He was defeated at first ; but having cut off all the chiefs of the tribe at a banquet, during an insidious peace which he had the art to conclude with them, he plundered the Eusofzyes of all their possessions; and drove them out of Caubul. The Eusofzyes, reduced to extreme distress, took the way to the neighbourhood of Peshawer.

That country wras then in a very different state from that in which it is at present. The tribes who now possess it were then in Khorassaun, and the plain of Peshawer, with several of the neighbouring countries, were possessed by tribes which have since either entirely disappeared, or have changed their seats. Lughmaun was in the hands of the Turcolaunees, who are now in Bajour; the tribes of Khyber and the Bungushes had already occupied their present lands, but all the lower part of the valley of the Caubul, all the plain of Peshawer, with part of $\mathrm{Ba}$ jour, Chuch, Huzaurel, and the countries east of them, as far as the Hydaspes, belonged to the Afghaun tribe of Dilazauk, which is now almost extir- 
pated. The country between the Dilazauks and the range of Hindon Coosh, on both sides of the Indus, formed the kingdom of Swraut, which was inhabited by a distinct nation, and ruled by Sultaun Oveiss, whose ancestors had long reigned over that country.

On the first arrival of the Eusofzyes, they threw themselves on the generosity of the Dilazauks, who assigned them the Doaubeh for their residence; but as fresh bodies arrived, they found their lands too confined, and, as their strength increased, they seized on the Dilazaulk part of Bajour, and engaged in a war with that tribe, in which they deprived them of all their possessions north of the Caubul river. They also expelled Sultaun Oveiss from his former possessions, and forced him to retire to the Caufir country, where he founded a new monarchy, which was enjoyed for some generations by his descendants.

During these wars, Ulugh Beg had died, and the kingdom of Caubul had fallen into the hands of the famous Emperor Bauber, who was then rising into notice. He several times attacked the Eusofzyes, but made no great impression on them, as they always found a secure retreat among their hills. At last, Bauber made peace with them, and secured them in his interests, by marrying a daughter of their Khaun. Bauber himself describes these campaigns in his Commentaries, and confirms the story of his marriage.

The operation of which I have given a summary, occupy the greater part of a pretty large volume in the Afghaun bistory; but the details would not repay the room they would occupy, and I can exhibit in a few words the little light they throw on the manners and character of the Eusofzyes. 
The whole tribe was under one Khaun during these conquests, and his power seems to have been much greater than what the modern Khauns enjoy. The people, however, seem still to have been turbulent and unruly; their first quarrel with the Guggeeaunees originated in an elopement with the affianced bride of a chief of that tribe, and was pursued by the Guggeeaunees with the same implacable spirit which such an outrage would excite at this day. The custams of Naunawautee, and of respect to guests, seem to have existed then as at present, and to have been sometimes infringed, as they are still. One anecdote may be mentioned, which shows the manners of the times in a strong light.

After a great battle between the Eusofzyes and Dilazauks, Mullik Ahmed, the chief of the Eusofzyes, was deputed to the Dilazauks to sue for peace. On his arrival among that tribe, they resolved to sacrifice him to their resentment for the loss of their relations, who had fallen in the battle; but Mullik Ahmed's situation, and perhaps the beauty of his person, excited the compassion of the wife of the Dilazauk chief, who informed him of his danger, and concealed him until the indignation of her clansmen had subsided; they then repented of a resolution so much at variance with the respect which the Afghaun customs exact towards a guest and suppliant; and when Mullik Ahmed discovered himself, they received him with distinction, and prepared an entertainment in honour of him. The bard who sung to them while they were seated at the feast, appears to have been less generous than the rest, for, as he sung the wars and victories of the tribe, he introduced the subject of the late 
battle, and in some extemporary verses, urged the chiefs to put to death their enemy, who was in their power. This advice was now thought so base, that they rose in indignation, and stoned the bard out of the assembly. Mullik Ahmed was allowed to return to his tribe, where, being asked his opinion of the Dilazaulks, he declared the bard was the only wise man among them.

In their behaviour to other tribes or nations, they appear to have united the ferocity and craft of savages with the moderation of a more advanced stage of civilization. They are stated to have given quarter to Afghauns taken in battle, through respect to their origin; from whence it may be inferred, that they gave none to Swautee prisoners: yet they treated the inhabitants of the conquered countries with mildness, and they seem to have firmly adhered to the maxim of never engaging in more than one war at a time.

When they had completed their conquests, they proceeded to divide the countries they had acquired. They assigned Hushtnuggur to the Mahommedzyes, who had arrived from Khorassaun about that period; and in their possession it still remains. The Guggeeaunees also had been expelled from the neighbourhood of Caubul by the Emperor Bauber, and had been reconciled to the Eusofzyes, who allotted to them the Doaubeh, which they still hold, and part of Bajour, from which they have since been expelled. All the rest of the country remained to the Eusofzyes, who, however, engaged to provide for certain inferior tribes; the principal among these, were the Otmaunkhail, to whom they assigned their present territory in the mountains east of Bajour. Punjcora, which 
seems then to have been part of Bajour, remained to the Eusofzyes, and the rest was some years afterwards occupied by its present possessors the Turcolaunees, or Turkaunees, who probably took it from the Deggaums.

The interior division of the lands among the subordinate branches of the tribe of Eusofzye, and among the individual members of those branches, is not recorded : it may, however, be easily ascertained from the present state of property. in the Eusofzye country, and it will be found to involve some very singular institutions. The tribe of Eusofzye is divided into two great branches, Eusof and Munder, the first of which acquired Swaut, Punjcora, and Boonere, and the latter the plain north of the Caubul river, with the valley of Chumla. The Eusof is again divided into three separate and now independent clans, the Accozyes, Moollezyes, and Lawezyes, of whom the former obtained Swaut and Punjcora, and the two latter Boonere. The complete property of the soil was vested in each clan, and the Swautees who remained were reduced to the condition of villains, or, as the Eusofzyes call them, Falseers.* This is the state in which things are at this day.

Each of these clans divided its lands among its Khails $\dagger$ at a general meeting of the clan, and this arrangement was repeated throughout all the subor-

* This phrase is used among the Uzbelrs for the peasantry. It is used here for the subjects of the tribe, who, in other parts of the Afghaun country, are called Ryots. In Persian they are termed Eel Ryots.

$\uparrow$ For an explanation of the divisions of an Afghaun tribe, see the Note and Table in Chapter II. of the second Book. 
dinate divisions. Each of the Khails received its lands in perpetuity; but a different arrangement was adopted within itself. The lands of each of its divisions were allotted only for a certain number of years, and were to be changed at the end of that period for those of some other, so that each might share equally in the fertility or sterility of the soil. Thus, each independent division of the Khauzoozyes retains the lands assigned to it at the original distribution; but the subdivisions interchange their lands, in a manner which I shall endeavour to illustrate by the example of the Naikpeekhail, a division of the Khail of Khauzoozye, and clan of Accozye, which is now an independent Oolooss, divided into six clans.

The lands of the Naikpeekhail are divided into two parts, equal in extent, but, of course, not exactly equal in fertility; the Oolooss is also divided into two parts, which draw lots every ten years for the choice of land. If the lot falls on the half which is already possessed of the best share, it retains its possession; but if it falls on the other half, an immediate exchange takes place. The two half Ooloosses meet every ten years to draw lots, at a village which lies on the borders of the two shares of lands. Vast numbers of people attend to witness the ceremony; but as the exultation of the victors, and the anger of the vanquished party, would produce tumults in such an assembly, the Mulliks put off drawing the lots on various pretences, till the people get impatient, and return to their homes. When the crowd is dispersed, the chief of the whole Naikpeekhail draws the lots, and announces the result, which is received in the victorious party with public distributions of charity, 
firing of matchlocks, aud all other marks of rejoicing. The change of lands is accomplished without much trouble or confusion; each clan of one half Oolooss is paired with a clan of the other, and the two thus paired, cross over into each other's lands.

When the lot has determined that the half Ooloosses are to retain their former lands, the three clans of each cast lots among themselves for a new distribution of their share, which is divided into three portions.

On the two last occasions, when lots were drawn among the Naikpeekhail, the half which had the worst share was successful each time, and, in consequence, there have been two complete interchanges of land within the last fourteen years. It is impossible not to suppose that the uncertain tenure on which the lands are held under this institution, must be a great bar to improvement : but, in spite of this obstacle, the Eusofzye country is cultivated with great industry and success, and the villages, water-courses, and other immoveable property, are as good as in most parts of Afghaunistaun. It might also be expected, that there would be a civil war in the Oolooss, as often as the land was to be exchanged; and, in fact, at the expiration of the last term but one, the half of the Naikpeekhail which was in possession of the best lands, refused to submit to the usual custom of drawing lots. The Mulliks of the other half complained loudly of this injustice, and called on all the other Accozyes to prevent the subversion of the ancient custom of the tribe; so many Ooloosses declared in their favour, that their opponents were forced to give way, and to draw lots as usual.

This custom is called Waish. It prevails through 
the whole of the Eusofzyes, and also among the Mahommedzyes. The period for which the lands are to be retained, however, varies throughout. In Bnunere, for instance, the Waish is performed annually. Among the Jadoons, a branch of the Eusofzyes, individuals interchange among themselves, but there is no Waish among clans. With the Otmaunkhail, on the contrary, the whole tribe cast lots every twenty years. Among the Gundehpoors in Damaun, also, the lands are divided into six shares, corresponding to the number of clans in the tribe, and all the clans draw lots for the order in which they are to choose their shares. The period at which this ceremony is to be renewed, is not fixed permanently as among the Eusofzyes, but while one Waish is taking place, it is determined in the council of the tribe, when the next is to happen; the term is generally from three to five years. What is most surprising is, that all these transactions take place among the lawless Gundehpoors, without quarrels or bloodshed.

None of the eastern Afghauns but those already mentioned, and two or three clans of the Oorookzyes, have this custom. There are some traces of its baving prevailed among some tribes in Khorassaun, but the only remaining instance of its existence that has reached me, is among the Baraiches, where village sometimes draws lots with village, or man with man, but without any Waish among clans.*

* This custom is stated by Volney to be still practised in Corsica. It appears, by the following observation of Tacitus, to have prevailed among the ancient Germans; but whether it was only individuals that moved, or whole societies, depends on the reading of a disputed passage. Agri pro numero cultorum ab universis per "vices"

VOL. II. 
What has already been said, will have prepared the reader for the utmost weakness of the government, if not for the absence of all government. A sense of independence, carried beyond the bounds which are essential to order, is characteristic of all the Afghauns; but most of their governments are despotisms, when compared with that of the Eusofzyes. The slender tie which holds their societies together, is derived from community of blood, and subordination to the representative of a common ancestor. Their government is patriarchal, but its effects are very different from those which have been attributed to that form of sovereignty. The head of the Khauzoozyes is the descendant of the eldest son of their common ancestor, but the last appearance of his power was in Naudir Shauh's reign, when all the Eusofzyes united to resist that conqueror. 'The head of the Naikpeekhail derives his authority from the same source. His powers do not require a long enumeration; he commands in war, subject to the resolutions of a council of the Mulliks, who in their turn are influenced by the opinion of the members of their clans. He sometimes interferes in disputes between two clans, but his success in accommodating their difference, depends

occupantur, quos mox inter se, secundum dignationem partiuntur; facilitatem partiendi camporum spatiæe præstant. Arva per annos mutant. Germania xxvi. If we rend "per vicos occupantur," as is recommended by many of the commentators, and as the sense seems to require, we shall have pretty nearly the mode of distribution which I have described: Cresnr also has the following passage:-Neque quisquam agri modum certum aut fines proprios habet, sed magistratus ac principes in annos singulos gentibus cognationibusque hominum, qui una coierunt, quantum eis et quo loco visum est attribuunt agri, atque anno post alio transire cogunt. 
more on his arguments than lis authority, and more on the caprice of the disputants than on either. Indeed the whole of his authority arises from his personal weight, and that is derived from his birth and his good conduct; he has no public revenue, and neither more wealth, more immediate clansmen, nor more hired servants than the head of any other clan. The heads of clans have not much more power; they are, however, referred to in disputes between individuals, particularly if they live in different villages; for each clan, instead of being assembled in one place, is scattered through different villages, which it shares with members of other clans, all, however, living in distinct quarters, and under separate chiefs. None of all these chiefs have authority equal to that of a constable in England.

It is hardly necessary to say that the Eusofzyes set the King at defiance ; they boast of their independence of him, and scarcely consider the tribes under his government as Afghauns. A famous saint among the Eusofzyes, is said to have left his tribe a blessing and a curse, "That they should always be free, but that they should never be united." Considering the Afghaun notion of freedom, he did not hazard much by the last part of his prediction.

I shall illustrate the above observations by an account of the proceedings of a part of the Ghalleekhail, one of the clans of the Naikpeekhail.

The part of the Ghatleekhail which I am to speak of, inhabits at present the village of Galoche, which is shared by portions of three other clans. Each clan live separately under its own chief (who is called Mushir, and who is subordinate to the Mullik of his 
own clan), and these quarters of the village are called Cundies. All the relations of each Cundy are to its own clan, and it does not seem more connected with the other Cundies in the same village, than if they lived in different parts of the country. The Mushir of each Cundy maintains a public apartment, where all councils are held ; here also the men meet to converse and amuse themselves; and here they receive guests and transact all public business, unmixed with the members of the other Cundies. Such an assembly of discordant materials into one spot, cannot take place without frequent convulsions. Accordingly, scarce a day passes without a quarrel: if there is a dispute about water for cultivation, or the boundaries of a field, swords are drawn, and wounds inflicted, which lead to years of anxiety and danger, and end in assassination. Each injury produces fresh retaliation, and hence arise ambuscades, attacks in the streets, murders of men in their houses, and all kinds of suspicion, confusion, and strife.

As these feuds accumulate, there is scarce a man of any consequence who is not upon the watch for his life. In every village are seen men always in armour, to secure them from the designs of their secret enemies, and others surrounded by hired soldiers, to the number of ten or twelve, and sometimes of fifty or a huudred.*

I have hitherto been speaking of quarrels between

* Anwur Khaun, the Mullik of the Ghalleelshail, always sleeps in his Hoojra, or public apartment, away from his women, surrounded by his male relations; his servants all sleep round, except four or five, who keep watch; all have their arms ready by them, and if one of them goes beyond the threshhold of the apartment, he must be guarded 
different clans, which one would think would unite the members of each more strongly among themselves. No such effect, however, appears. Even within the clans there is nothing like peace or concord; the slightest occasion gives rise to a dispute, which soon turns into an affray. The Mullik, or chief of the Cundy, interposes, remonstrates, soothes, threatens, and entreats; but his instances are often disregarded, and the quarrel continues till one party feels himself the weakest, and leaves the village.

An account of a particular quarrel, which I shall relate almost in the words of Mozirrib Khaun, will show the nature of the feuds and reconciliations among the Eusofzyes, the weakness of the chiefs, and the turbulence of the clansmen, better than any general remarks I can offer.

Mozirrib's father had a dispute with a man named Sirundauz, about the boundaries of their lands : high words passed, and in the end Mozirrib's father was wounded. Anwur Khaun, his brother, and uncle to Mozirrib, is the head of all the Ghalleekhail, yet he had no means of redress beyond those possessed by any other individual. A Jeerga was held on the occasion, which does not seem to have had much effect. A few days afterwards, when Anwur Khaun went to the Hoojra, accompanied by Mozirrib, then only sixteen, and ten or twelve of his relations, some well armed, and others having only their swords, they found Sirundauz there, with twenty of his friends in

by four or five armed men. I have been told by Mozirrib Khaun ( the nephew of Anwur Khaun, a lad about eighteen years old), that he has seen several attacks on this apartment by one of the Cundies of the same village, but they failed from the alertness of the defendants. 
full armour. This did not deter Anwur Khaun from reproaching himwith his behaviour; his attack brought on the usual consequences, a desperate affray took place, in which Mozirrib received a severe cut on his head, and Anwur Khaun was covered with wounds: many of his relations were also wounded. A son of Sirundauz, and another of his partisans, were killed. As Anwur Khaun had killed the first man, he was considered to be in the wrong, and was obliged to fly with all his family. At last he was wearied with his exile, and submitted to Sirtundauz, giving him his sister and his niece (a sister of Mozirrib's). Sirundauz behaved with courtesy; he said he considered Anwur's sister as his own, and restored her to her relations; but he jkept the other without marrying her (for the Naikpeekhail never marry a woman given in price ut blood), and from that day Mozirrib saw his sister no more. The pursuit of blood had indeed been put an end to, but no intercourse took place among the families; Sirundauz and Anwurnever meet when they can avoid it, and when they do, they turn their head saway. Mozirrib, in answer to a question, what he would do, if he met Sirundauz alone, replied, that he would instantly attack him, that he might anticipate the assault which Sirundauz would assuredly make on him. Such fury after a reconciliation would be blamed even among the Naikpeekhail, but says Mozirrib, "A man's heart burns for his relation that was killed."

Such is the life of the greater part of the Eusofzyes. Where the chief is powerful, fewer disorders occur, and the Naikpeekhail is among the worst, if not th: very worst, of the democratic clans ; but similar accounts are given of many other clans, and in most 
parts of the country the inhabitants live in perpetual fear, like savages, and plough and sow with their matchlocks and their swords about their persons.

It might be expected that the dangers of this state of anarchy would force the weak to throw themselves on the protection of others, who were stronger than themselves, and that by these means, there would be little real independence left among the people. It is probable that Kaussim Khaun, and some other chiefs (if such there be), as have established their authority over their tribes, may have derived some support from this principle; but among the Naikpeekhail and other democratic Ooloosses I can discover no trace of such a system.

The horrols of these domestic feuds are sometimes aggravated by a war with another Oolooss. Many causes occasion these wars, but the commonest are the seduction of a woman of one Oolooss by a man of another, or a man's eloping with a girl of his own Oolooss, and seeking protection from another. This protection is never refused, and it sometimes produces long and bloody wars. I shall show their nature, as usual, by the example of the Nailspeekhail.

The wife of a Fakeer of the Naikpeekhail eloped into the lands of the Bauboozyes. The Fakeer followed with some of his relations to kill his wife; and as he was lurking about for this purpose in the niglut, he was set upon and killed, with one of his relations, by the person who had carried off the girl, and some of his new protectors. When the news reached the Naikpeekhail, their Khaun sent a drummer to summon the Mulliks of the six clans, and consulted with them on the propriety of a war. The 
Mulliks returned to their clans, and conversed with the heads of Cundies, who took the sense of the people at meetings in the Hoojra ; all were eager for revenge, and in three days the whole Oolooss assembled in arms, and marched on the same night to an embankment which turned part of the river of Swaut into the lands of the Bauboozyes. They broke down the embankment, and erected a redoubt to prevent its being rebuilt.

The Bauboozyes, who saw the water cut off from their cultivation, immediately assembled, and marched against the redoubt. The Naikpeekhail were six thousand, and the Bauboozyes much more numerous. Both sides had some horse, and some hundred Jailumees (champions distinguished by a fantastic dress, and bound to conquer or die).

The rest were a mob, some in thick quilted jackets, some in plate armour, some in coats of mail, and others in leathern cuirasses; all armed either with bows or matchlocks, and with swords, shields, long Afghaun knives, and iron spears.

When the armies came in sight, they at first fired on each other; afterwards the Jailumees turned out, and engaged with the sword; at last the main bodies came into close combat. The brave men on each side were mixed together, and fought hand to hand; the cowards, who were much the greater number, hung back on both sides, but joined in the general clamour; every man shouted and reviled his adversaries with as loud a voice as he could. Even the women of the Fakeers (for those of the Eusofzyes could not appear in public) stood behind the line, beating drums, and distributing water to refresh the weary. At 
last botlı sides were exhausted, and retired to their homes.

Numbers on both sides were killed and wounded. It was, says my informant, a tremendous battle; songs were made on it, and the news went to Peshawer to the King.

It led, however, to no important result ; the redoubt remained, the lands of the Bauboozyes were ruined for want of water, the war continued for three years, many other Ooloosses joined each side, and the whole country up to the mountains was embroiled. At last many Khauns of neutral Ooloosses interposed, and meditated a peace.

Few prisoners are taken in these wars; those who are taken are at the disposal of the captors, who keep them for some time, and make them labour at their fields, but always release them at last without ransom.

The political state of almost the whole of the Eusofzyes, is shown by what I have said of one Oolooss. Some, however, are under a more aristocratic government. In those cases, the riches or abilities of the Khaun give him a weight which he does not possess among the Naikpeekhail. I am not, however, acquainterl with any instance of considerable power of the Khaun in any of the Eusofzyes, west of the Indus, except in Punjcora. The Judoons, a numerous branch of the Eusofzyes, who live east of the Indus, allow great power to their chiefs, and, in consequence, are exempt from the strife and bloodshed which prevails among the other Eusofzyes.

By far the most powerful Khaun among the Fiusofzyes is Kaussim Khaun of Deer in Punjcora, chief of the Mulleezyes. I have not the means of giving 
the particulars of the policy by which he attained his power. It is, however, certain that he possessed considerable treasures, and acquired large estates by purchase, or usurpation on his own relations. $\mathrm{He}$ next set himself to put down private revenge, and its concomitant disorders. He drove many offenders out of the tribe, and appropriated their lands to himself, He connected himself with neighbouring chiefs, and encouraged and assisted them in strengthening their power in their Ooloosses. He also reduced many of the nearest Caufirs, and exacted a tribute for himself; and, by means of these revenues, and the produce of his estates, he entertained men in his own pay, and acquired a decisive influence in the tribe. His greatest exploit, and that which contributed most to raise his reputation and strengthen his influence, was a successful war which he undertook against the-Sultaun of one of the four little kingdoms of Kaushkaur. Kaussin Khaun, after surmounting great difficulties in passing over the snowy mountains, took the capital, and, I believe, dethroned the prince : but he did not attempt to retain the country.

The whole of the Oolooss are now completely at his devotion. He can imprison, inflict corporal punish.ment, and even put to death. He has extirpated domestic feuds, and has established a good police, so that his government is far from being unpopular even among his Eusofzye subjects. All the Fakeers in Punjcora now belong to him, and pay him a tax; but he derives no revenue from his clan.

Kaussim Khaun has shown a disposition to encroach on some of the democratic Eusofzyes in his neigh- 
bourhood, but as yet without success. On these occasions it seems to have been his plan to form a party within the tribe.

It is impossible to enumerate all the little republics of the Eusofzyes. I have got the names of at least thirty of them, all as little connected with each other as the Naikpeekhail are with their neighbours; but it is probable the number of independent communities is still more considerable. The whole numbers of the Eusofzyes are reckoned by the Afghauns at 900,000 ; but, on a calculation of the extent and fertility of their country, I should be inclined to conjecture that their numbers, including all their Fakeers and dependants, did not exceed 700,000 souls.

The Fakeers are much more numerous than the Eusofzyes. The greatest part of them are Swautees, who remained in their country after it was conquered; a considerable number of Deggauns; some Hindkees (who have been driven by famine to emigrate from the Punjaub); a few Cashmeerees and IIindoos (classes which are led into all countries by the desire of gain); and some members of Afghaun tribes (who have migrated into the Eusofzye country in circumstances which have degraded them to the rank of Fakeers), from the rest of that body. Most of the Fakeers work in husbandry, and many feed herds of buffaloes on the mountains.

The Fakeers have no land; they are not considered as members of the commonwealth, nor allowed to be present at Jeergas. Every Fakeer is subject to the person on whose land he resides, who is called his Khawund, or master. He pays a tax to his master, 
and is also obliged to work for him gratis, like the villains in Europe. The master can also beat or even kill his Falreer, without being questioned for it. On the other hand, the Fakeer is sure of zealous protection from his master, who would enter into the most desperate quarrel rather than suffer another person to injure his Fakeer. The Fakeer is at liberty to pursue any trade, to work as a labourer for his own profit, and even to rent land as a Buzgur or Metayer; his master having no demand on him but for his established tax, some fixed dues, which will be mentioned hereafter, and a share of his labour. The treatment the Falkeers receive from their masters is generally mild. The master is deterred from severity by the disgrace which attaches to oppression, and still more by the right of the Fakeer to remove to the lands of another Eusofzye; a right which he can always exercise, as there is a great competition for Fakeers, and many men will always be found ready to receive and protect one who is disposed to change his master. The number of independent communities is also a protection to the Falseers; as one of them who had received any mortal injury (as the murder of his relation, or the seduction of his wife), could revenge himself by the death of his oppressor, and then secure himself by flying into the country of another Oolooss.

The masters have not the power of extorting money from their Fakeers. They levy fines on the settlement of a new Fakeer in their lands, and on the marriages of their Fakeers, and also as a punishment for murders and other crimes; but the amount, like that of the tax, is fixed by custom, and it would be 
reckoned gross oppression to levy more than was due. The Fakeers have their quarrels and their bloodshed, as well as the Eusofzyes, but in a far less degree. They are indeed an liumble unwarlike people, and seldom carry arms, though they are not forbidden to do so. Their houses are generally worse, and their dress is plainer, than that of the Afghauns. They are all frugal, and often amass considerable sums by the profits of their labour, particularly when they are artizans, and by the increase of their herds.

Besides the Fakeers employed in husbandry, there are many who work as masons, weavers, dyers, \&c. the Afghauns never practising any of these crafts. The situation of some of these tradesmen is peculiar. The blacksmiths, carpenters, and barbers, together with the drummers, are attached to particular Cundies, have a share of land, and work gratis for the Cundy, which they follow when it changes its residence. All the others remain fixed, and are paid by individuals; even the master of an artizan is obliged to pay him for his rork. Afghauns who coine from distant tribes, and whose connections are not known among the Eusofzyes, are obliged to settle as Fakeers ; but Eusofzyes, who move from one Oolooss to another, particularly if they have not been obliged by poverty to sell their lands, are received as equals, and a portion of land is assigned to them on condition of serving in war, like the members of the Oolooss. They are not, however, consulted on public affairs, but are under the protection of some individual who looks after their interests. Some of the Deggauns, who are reckoned a martial people, are 
also allowed to serve with Eusofzye Ooloosses, and their assistance is repaid by grants of lands, where they live together under chiefs of their own.

The state of the Fakeers is not exactly the same in all clans; in some they are exempt from paying a tax; and the amount of it, and of the fines, vary in other's.

Before I quit the general concerns of the Oolonss, I have to observe, that most tribes levy customs on gcods, that enter or pass through their country. The produce sometimes goes to the Ooloosses, but oftener to the chief.

Their trade out of their own limits, is not considerable. They export grain to Peshawer, and import some of the finer manufactures, but those in ordinary use are made at home.

What I have said of their government, has already thrown some light on the manners of the Eusofzyes; what remains, shall be added to a slight account of their customs and habits of life.

The houses in the Eusofzye country, have generally flat, terraced roofs. They consist of two rooms and an open porch. The inner room belongs to the wornen; the outer one is used for the men to sit in, and for the reception of visitors, but in hot weather the porch is used for these purposes. They sit on low beds, made of leather stretched over a wooden frame; five or six of which, with some quilts to sleep under, some earthen and wooden vessels, and some trunks for clothes, compose the whole furniture of a house. They have always two meals a-day; breakfast, which consists of bread, milk, and a sort of curds; and a dinner composed of bread, 
pulse, and other vegetables, with an addition of meat, but very rarely. In summer, when the days are long, they take a luncheon of hot bread at noon.

The ordinary dress of the men is a cotton tunic, made to fit the body down to the waist, and then lonse and full down to below the knees; it is either dark-blue, or dyed grey with the bark of the poniegranate tree. They also wear a large, Joose, white turban, a pair of cotton trowsers, and a pair of sandals; but their dress is not complete without a Loongee, * which hangs over the shoulder, and reaches below the middle, both before and behind. It is sometimes used for a cloak, and sometimes for a girdle. They have always a better suit of clothes for Fridays and great accasions. The tunic is then made longer and fuller below, and is puckered up about the waist in numerous plaits. The rest of the holiday clothes are of coloured silk, except the turban.

The women wear a gown close over the breast, and very wide below. They wear many gold and silver ornaments, like those used in India. Neither sex wear the long shirt which is so common among the other Afghauns. The women of the Eusofzyes are carefully concealed, and never leave their houses without putting on the cloak called a Boorka, which covers them from head to foot. The women do not work out of doors; those of the poorest men bring in water, but they always do so by night.

The villages are built in streets, but without any particular regard to order. They are, however, very neat and clean, and have many mulberry trees, and

* A large handkerchief of blue sillk and cotton mixed. 
other fruit trees planted up and down them. Every house has a little garden and a few vines.

Most of the labour being done by the Fakeers, none but the poorest Eusofzyes are obliged to work; the others sometimes take a share in the labours of their own fields, but it is rather for exercise, and to set an example, than to work in earnest. They, however, superintend the cultivation, and direct the operations of the Fakeers and hired labourers. When not so engaged, they go to the Hoojra, where, in winter, they spend the greater part of the day in conversing and smoking round a fire. Culleauns are kept there for public use, as few people smoke at home. They have sometimes boys, and sometimes women, to dance, and sing ballads and other songs. The Eusofzyes themselves seldom sing, and never play at any of those active games which delight the simple inhabitants of Khorassaun. Their only amusements are firing at marks with bows and arrows, or matchlocks, and exercising themselves in the use of the sword.

Living among a conquered people, like Spartans among Helots, and enjoying entire independence on all around, every Eusofzye is filled with the idea of his own dignity and importance. Their pride appears in the seclusion of their women, in the gravity of their manners, and in the high terms in which they speak of themselves and their tribe, not allowing even the Dooraunees to be their equals. Their independence and continual quarrels make them suspicious and irritable, render their manners repulsive, and take away the openness and plainness which pleases so much in the other Afghauns. They are generally stout men, 
but their form and complexion admits of much variety. In those whose appearance is most characteristic of their tribe, one is struck with their fair complexions, grey eyes, and red beards, by the military affectation of their carriage, and by their haughty and insolent demeanour. 'They are all brave and hospitable, though far inferior in this quality to the western tribes. They are, however, liberal to their own clansmen. If a man is reduced to poverty so as to be unable to hire a labourer, or to be obliged to sell his land, he is observed to fall into low spirits from wounded pride, and, if he is not soon relieved, quits his tribe, and goes on a pilgrimage to $\mathrm{Mecca}$, or sets out to try his fortune in India; but if he be a brave and respectable man, his wants are no sooner known, than a subscription is made for him, and he is placed in a situation which allows him to remain at home without shame. Another mode of obtaining relief is practised, but is rare, because it is considered a s degrading. It is brought about by the distressed person going round the villages in his neighbourhood, and stopping outside of each, and waving his Loongee. The signal is immediately understood, and never fails to produce a contribution.

The Eusofzyes of the upper countries are remarkably sober, and free from vices, but those of the plains are notorious for every sort of debauchery; vices which are not to be named, are practised universally with the most disgusting publicity ; and gambling, and the intoxication which is produced by opium, bang, and other drugs, are carried to the utmost excess. Nevertheless, these very tribes are remarkable for their religious zeal and intolerance, for their atvoL. Tr. 
tention to all the forms of devotion, and for the profound respect which they bear for Moollahs. The tyranny of these priests is there carried to an intolerable pitch. They connive at the notorious vices of the people, in which indeed they share themselves, but they abstain from going to the most innocent meetings at the Hoojras, as inconsistent with the sanctity of their character; and they punish an omission of the stated prayers, or a breach of the established fasts, by public exposure on an ass, and by severe corporal punishment.

Very different is their condition in the mountains, and particularly in Upper Swaut. They are far more really respectable there than in the plains; but as they are timid and unwarlike, they are held in contempt, and treated little better than Fakeers. Even reading is looked down on there as an unmanly accomplishment. Some men of the Naikpeekhail found a Moollah copying the Koraun, and not well understanding the case, they struck his head off, saying, "You tell us these books come from God, and here you are making them yourself." The other Eusofzyes of the village blamed the murderers, explained their mistake, and made them own they had been inconsiderate; such is the importance attached to the life of a Moollah among the Naikpeekhail.*

* The numbers of the Eusofzyes that are to be met with in India, recal my attention to the Afghaun emigrations, which I have omitted in the proper place. The frequency with which they emigrate, seems inconsistent with the love of their country, which I have ascribed to them; but the same thing takes place among the Highlanders, whose local attachments are known to be so strong. The cause is the same in both cases; the absence of trades among the Highlanders; and the 
Bajour is bounded on the west by the southern projection of Hindoo Coosh, and on the east by the hills of the Otmaunkhail. These ranges also close it on the north, so as to leave but a narrow opening into Punjcora; on the south it has the hills of the Upper Momunds. It is an undulating plain, about twenty-five miles long from east to west, and twelve from north to south. Several long and wide valleys run down to it from the surrounding mountains, which in other places are inaccessible, not more from their steepness than from the thick woods with which they are covered. The plain resembles that of Peshawer, which it equals in fertility; wheat is the

disgrace of engaging in them among the Afghauns, render land abso. lutely necessary to the support of each individual, and whoever is without land, must quit the country. In the west of Afghaunistaun, where marriages are late, and land plenty, emigration is rare; but the elst has poured out a continued stream of adventurers, for a period of great duration. These huve always taken the direction of Indin. The greater part of that country was many centuries in the possession of Afghaun dynasties, and, even after their fall, the Mogul armics were always recruited by foreigners in preference to watives. These causes filled India with colonies of the descendants of Afghauns; who are now called Patans, and who are found in all parts of Findostan and the Deccan, sometimes mixed witl the rest of the inhabitants, and sometimes collected under chiefs of their own, like the Nabobs of Furrukabad and Boparl, Curnoule and Cudduppa. The greatest colony is that founded chiefly by Eusofzyes, at no very remote period. I allude to the settlement of the Rohillas, whose wars with us have rendered their name so well known in England. An account of their establishment may be found in Hamilton's Rohilla Afghauns, and of their downfall in the Parliamentary Reports. Their constitution had nothing of the Afghaun democracy; the chiefs were the lords of the soil, and the other Afghauns their tenants, and generally their soldiers; but there, and every where, the common Afglauns showed an independence, and the chiefs a spirit of concilia- 
chief produce. It is divided by a stream which rises in the southern projection, receives a brook from each of the valleys, and, after joining the Daunishkool, in the country of the Upper Momunds, falls into the river of Swaut above Hushtnugger. The two chief towns, Bajour and Nawagye, contain each about one thousand houses. The plain is comected with Punjcora by a long valley which ascends to the latter district; it is called Berawul ; part of it is well cultivated, but the rest is occupied by a deep forest of various trees, among which are the oak, and perhaps the cedar.* The forest abounds in wild beasts, and

tion, peculiar to themselves. The turbulence and arrogance of these Ersofzye colonists, render them unpopular among the English gentlemen; who, on the otlier hand, are disliked by the Rohillas for the assistance they gave to the Nabob Vizier, in conquering their country; but all admit that the Rohillas are the bravest soldiers we have ever contended with in India. Their kindness to their Hindoo subjects cannot be denied; and the state of improvement to which they had brought their country, excited the admiration of our troops, and has been displayed with enthusinstic eloquence by Burke. The coldest phrases express that " it was cultivated like a garden, without one neglected spot in it." Even now it is among the richest parts of the British provinces. It consists of vast plains, covered with fields of corn, or orchards of Mangoe trees, and filled with populous towns and flourishing villages. The city of Barelly is one of the largest and finest in India; and an agreegble little town called Nugeena, where I was encamped for some weeks, contains at least 18,000 inhabitants, although $i t$ is in no map, and is scarcely heard of beyond the limits of Rohilcund. The residence of the Nabob is at Rampoor, the manners of which place still resemble those of the Berdooraunees. Pushtoo is the principal language, and one sees in the square before the Nabol's palace, fair, strong, and handsome young men, sitting or lounging on beds, with that air of idleness and independence which distinguishes the Eusofzyes.

* It is called Billundzye, and is said to be a very lofty tree, like a fir, but with red wood. 
is in most parts so thick as to exclude the sun, and almost to keep off the rain. Berawul is distinguished from the rest of Bajour, by its having a separate chief.

Bajour belongs to the Afghaun tribe of Turcolaunee, or Turkaunee, but it also contains other inhabitants; the upper hills being inhabited by converted Caufirs, the lower by Hindkees, and the plain by a mixture of all tribes' and nations, confounded under the common name of Roadbaurees. The number of the Turcolaunees amount to ten or twelve thousand families, and those of the other inhabitants may be guessed at thirty thousand souls.

The Turcolaunees are under the government of a chief, called by the peculiar name of Bauz, who has great power over his tribe. The Caufirs pay him tribute, the Hinclkees pay him a tax, and the Roadbaurees rent their land of him for a fith of its produce. This gives him a revenue of one hundred thousand rupees, by which he is enabled to keep up some hundred horse, and a considerable body of foot, of whom he furnishes five hundred to the royal army. He administers justice in his tribe, with power to banish, beat, or bind. He, however, seldom inter. poses, unless the public peace is disturbed, and he seldom calls a Jeerga.

This absolute government, and the want of Fakeers, make the character of the Turcolaunees a contrast to that of the Eusufzyes, whom they resemble in their food, lodging, and habits of life. Though brave, they are industrious, but cheerful and fond of amusement, 'They often meet to converse, sing, and play on the guitar; and they have even some of the active games 
of Khorassaun. The few I have seen, seemed to bear some resemblance to the Mussulmans of India, particularly of the Deckan: like them they were civil and obsequious, but boastful ; and lively, but burried and confused; like them also they spoke much, and used a great deal of gesture. Their dress is the Afghaun cameess, and a little cap of wrought silk. They fiequently invade the Caufirs for plunder, and to carry off slaves; the Caufirs retaliate, but only by ambuscades and surprises, being too weak for open war.

At present the Turcolaunees are broken into two divisions, in consequence of the government's being disputed between the two nephews of the late Bauz.

The hills of the Otmaunkhail separate Swaut from Bajour. They are divided from the lower ranges of Hindoo Coosh, to which they evidently belong, by the valley of Punjcora. They are of considerable but unequal height. The snow lies for five or six months on the highest. Their northern face, though steep, has a gradual ascent, but the southern face is abrupt and precipitous; cattle often fall from the cliffs, and are dashed to pieces. The northern side is partially cleared and cultivated. Almost the whole of the cultivation is carried on on terraces, * rising above each other on the slopes of the mountains.

Besides these hills, the Otmaunkhail have a slip of level country on the skirts of Bajour, and two long but narrow valleys which open into Lower Swaut.

* I have never seen these terraces in the Otmaunkhail country, but if they resemble those I have seen in the country under Sreenuggur, no mode of cultivation can be imagined that requires greater industry, and malies less returns. In that country, walls are made along the 
The Otmaunkhails come abroad so little, that I never saw one at Peshawer, and have met but one since I was there. They are on bad terms with their neighbours, who have given them the character of a barbarous and lawless horde: they describe them as tall, stout, and fair, but say that they often go naked from the waist upwards, that the women labour like the men, and that every thing among them shows the absence of civilization.

But the Otmaunkhail whom I have seen, was himself a mild and intelligent man, and gave the following account of his tribe.

They have a Khaun, who possesses great power, and punishes bloodshed by heavy fines, and by awarding compensation to the relations of the deceased.

They have frequent quarrels among themselves, but not so many as the Eusofzyes; and they are at war with the Turcolaunees.

Their dress is like that of Bajour, and in their' customs with respect to women, they do not differ much from their neighbours. They are a sober people, and have none of the vices of the Eusofzyes. They live in small villages of from ten to sixteen terraced houses. On the whole, they are probably less civilized than their neighbours, and the strength of their own country may tempt them to plunder, as it secures them impunity.

They are never reckoned at less than ten thou-

sides of the hills, and filled with soil from the lower part of the hill; the walls are from three to ten feet high, and the terraces about five yards broad. The walls are soon concealed by grass and other vegetation, and as they are never straight, but consult the bends in the surface of the hills, the effect is pleasing and picturesque. 
sand families, a great number, considering the nature of their country, but rendered more reasonable by the circumstance of their having no other subjects or Falkeers.

The hills of Otmaunkhail turn to the westward when they approach the Caubul river, and stretch in that direction nearly to the river of Kaushliar, where they are joined by other branches from the southern projection of Hindoo Coosh. All this part of the hills belongs to the Upper Momunds, who also possess the plain between their hills and the Caubul river, and part of the nearest hills and plain on the southern side of the same stream. The southern part of their country is included in Khyber, and for this reason the Upper Momunds are often counted among: the Khyberees.

The hills are generally low, but stony and rugged. Snow only lies on them for a few days, except on Caubul Suffer (a hill near the north bank of the river). They are bare, except in some places, where they have tlickets and scattered bushes of different kinds, and (in some hollows) the usual mountain trees. Many parts of them are uninhabited.

The wastes are covered with a bush called Murriz, which is like the top of a palm tree, but is no higher than a man.

The climate is cold for four months; but the heat of summer is extreme. The sumoom is often fatal, and the blasts from Maur Coh (one of the hills south of the river), are the dread of all travellers in the hot season.

The Currapa Pass, which leads from Peshawer to Jellallabad, is in the Momund country; it is some- 
times travelled, but as it abounds in rugged ascents and defiles, and as the Caubul river, there stony and rapid, must be often crossed, the southern road through Khyber, is generally preferred.

The numbers of the Upper Momunds are said to be ten thousand families; a population in which I can scarcely believe, as many parts of the hills are uninlabited, and others thinly peopled, while the population of the plains is probably composed in part of Hindkees.

The government is singular. The direct power of the Khaun is small, except in military expeditions, but his influence with the Mulliks is great, and their authority is strong in their clans. The Khaun takes no share in the administration of justice, the Mulliks settle disputes by means of Jeergas. The Khaun derives no revenue from the tribe, and has no greater share in the Momund country than any other individual, but he holds some lands of the King, and receives a pension besides; in return, he is answerable for the safety of travellers in the Currapa Pass, and furnishes from three to five hundred horse for the royal army. Travellers would be plundered who attempted to go through the Momund country alone, but a single Momund will pass a whole caravan.

Their dress and food are like those of Bajour, but their dwellings are hovels made of mats.

They live in very small hamlets, and the shepherds are scattered over the hills in single cottages, which are only inhabited in summer. Their large villages, Laulpoora, Kaumeh, and Goshteh, contain only terraced houses, and are considerable places. The two last are walled. They are inhabited by 
chiefs and their retainers (who are not generally Momunds), and by Hindkees.

Most of the country people are employed in agriculture, and some in feeding flocks on the uninhabited parts of the hills. In winter, these employments are suspended, and they fill up their time at home, with Inaking mats, sandals, \&c., from the leaves of the dwalf palm. They export their mats to Peshawer, and also carry grain to the large villages, receiving returns in salt, cotton, cloth, coarse silks, and some other articles.

Two Khails of the Upper Momunds, live in black tents, keep camels, and move in spring with their flocks to the upper part of the Heelinund in Khorassaun. These are the only moving hordes among the Berdooraunees.

The Khyberees live among the heads of the numerous branches which issue from the northern and eastern faces of Speenghur, or Sufaid Cols. They derive their name from the valley or pass of Khyber, which extends on the right of the Caubul river, between Peshawer and Jellallabad, and forms the northern border of their possessions; they are bounded on the west by the uninhabitable summits of Sufaid Coh; on the south they have the Bungush country, and on the north-east the plain of Peshawer; but, on the south-east, they extend along the Range of $34^{\circ}$, nearly to the Indus.

The country is very diversified. The upper part is situated on the steep side of a lofty mountain, and the lower among bare and rugged hills, and rich but narrow valleys.

The climate varies from great cold to excessive 
heat. In general it is cool, but the lower valleys are hot, from the stagnation of the air occasioned by the mountains which surround them, and the low bare hills are there, as every where, intolerably hot in summer.

The Khyberees consist of three independent tribes, exclusive of the Upper Momunds. These are the Afreedees, Shainwaurees, and Oorookzyes. Altogether they are about 120,000 souls. The Shainwaurees are the least numerous, but they are the best people of the three, and most subject to the King's authority. The others are secured from subjugation by the strength of their country; but the importance of the Khyber pass (the great communication between Peshawer and Caubul), renders it necessary for the King to have some control over their proceedings. They accordingly receive great pensions, on condition of answering for the quiet of the road; but such are their habits of rapine, that they can never be entirely restrained from plundering passengers; and when there is any confusion in the state, it is impossible to pass through their country. The Khyber pass is about twenty-five miles long, over steep ridges, and through very narrow defiles. The road is often along the beds of torrents, and is extremely dangerous in the event of sudden falls of rain in the hills. In quiet times, the Khyberees have stations in different parts of the pass, to collect an authorized toll on passengers, but in times of trouble, they are all on the alert: if a single traveller endeavours to make his way through, the noise of his horse's feet sounds up the long narrow valleys, and soon brings the Khyberees in troops from the hills and ravines; but if they expect a cara- 
van, they assemble in hundreds on the side of a hill, and sit patiently, with their matchlocks in their hands watching its approach.

The Khyberees are lean, but muscular men, with long gaunt faces, high noses and cheek bones, and black complexions. They wear, in winter, at least, dark-blue turbans, and long dark-blue tunics, sitting close to the body, but reaching to the middle of the leg. They wear neat sanclals of straw, or the leaf of the dwarf palm; carry matchlocks, with a wooden fork attached to the barrel for a rest, swords, and short spears; and have altogether an appearance more strange and uncouth than any other Afghauns I. ever saw.

In their valleys they have terraced houses, but in the mountains, which they chiefly inhabit in summer, they have moveable huts of mat, like those of the Upper Momunds. They come down into the low hills in winter, where they cliefly live in caves cut out of the earthy part of the hills. They are extremely impatient of heat.

They are excellent marksmen, and are reckoned good hill soldiers, though of no great account in the plain. They are often employed in this surt of warfare, as far from their country as Kote Kaungra in the eastern extremity of the Punjaub. They are, however, more disposed to plunder than war, and will fall on the baggage of the army they belong to, if they find it unguarded. It was thus they behaved to Shauh Shujah in the heat of the battle of Eshpaun, and by these means lost him the day.

On the whole, they are the greatest robbers among the Afghauns, and I imagine have no faith or sense 
of honour, for I never heard of any body hiring an escort of Khyberees to secure his passage through their country, a step which always ensures a traveller's safety in the lands of any other tribe.

The plain of Peshawer, which lies immediately to the south of the Eusofzyes, is nearly circular, and about thirty-five miles in diameter. It is surrounded by mountains on all sides, except the east, where a narrow slip of barren country runs along the banks of the Caubul river to the Indus. This slip is about fifteen miles broad, and lies between the mountains of Boonere and the Range of latitude $34^{\circ}$, which bounds the plain of Peshawer on the south; on the south-west of the plain are the hills of the Khyberees, round the lofty peak of Suffaid Coh; on the west are the hills of the Otmaunkhail and the Upper Momunds, over which are seen far higher mountains.

The soil of the plain is a rich black mould. The surface is wavy, but the whole plain lies so much lower than the surrounding countries, that the water reaches almost every part of it, and secures it a perpetual verdure. This abundance of water is even sometines felt as an inconvenience in the lower parts of the plain, and particularly in the town, part of which is flooded in the spring rains.

The following are generally called the tribes of Peshawer :

The Mahommedzyes.

Guggeeaunees.

Momunds.

Khulleels, and

Dawoodzyes. 
The Mahommedzyes and Guggeeaunees live on the Eusofzye side of the Caubul river: their settlernent has already been related. Their manners resemble those of the Eusofzyes; but they are in obedience to the King, and under strict subjection to their own chiefs. The chief place of the Mahommedzyes is Hushtnugger, which may either be considered as one very large town, or as eight contiguous villages.

The Mahommedzyes are reckoned at eight thousand, and the Guggeeaunees at five thousand families.

The three others form the Ghoree or Ghoreeakhail. About the middle of the fifteenth century, they were settled to the west of Ghuznee, along the river Turnuk, and in Bauber's time (about A. H. 915), the Momunds at least seem to have been to the south of Ghuznee. They appear at that period to have been partly, if not entirely, pastoral.

They descended to Peshawer in the reign of Caumraun, the son of Bauber, and with the assistance of that prince, drove the Dilazaulis across the Indus. Of that numerous and powerful tribe; there are now only two or three villages to the west of the Indus. There, are, however, some thousand Dilazauks on the Indian side of the river.

From their residence in an open plain, these tribes must always have been in complete dependence on the King. They are, indeed, the most subject of the Afghaun tribes, and are, in consequence, exposed to oppression, which they bear with a good deal of impatience. The chief injury which they suffer, is from the troops foraging in their fields while the King is at Peshawer. They have twice rebelled, and are said 
to have had a design of expelling the King's governor, and initating the independence of the Eusofzyes, which they certainly admire and envy.

The chiefs of the tribes are here called the $\mathrm{Ur}$ baubs; their powers vary in the different tribes; they are greatest among the Momunds. Trifling disputes between individuals are settled by the chief, or by a Jeerga, but all important causes are investigated by the Cauzy, or the Sirdar of the city. In general there is great tranquillity in Peshawer, but in summer, when the King and his troops are absent, strong signs of the turbulence of the Berdooraunees break out, and tribes often fight about water for their fields.

The houses, food, and habits of life of the tribes of Peshawer, resemble those of the Eusofzyes. The dress has also some resemblance, being a mixture of that of the Indians with that of the Afghauns. In winter they generally wear dark-blue coats of quilted cotton, which are thrown aside as the summer advances, when a large Afghaun shirt, and a white or blue turban, form the dress of the greater number of the people. A Loongee, either twisted round the waist, or worn over the shoulder, is always part of their attire. Though not destitute of the Berdooraunee spirit of contention, their manners are generally mild, obliging, and inoffensive. Their minds are extremely active and acute, and they are less simple, and more given to fraud and chicane, than most of the Afghauns.

I have already mentioned that Peshawer is the favourite winter retreat of the Kings of Caubul. Shauh. Shujah was particularly fond of this place 
and its inlabitants, who repaid his partiality by a strong and steady attachment.

The division of Momunds which resides in the plain, is reckoned to amount to twelve thousand families. It has no connection except in blood with the Upper Momunds. The Khulleels are six thousand families, and the Dawoodzyes ten thousand. The rest of the inhabitants of the plain are Hindkees. The whole population must exceed 300,000 souls.

The slip of barren country between the Indus and the plain of Peshawer, is divided between the Khuttuks and Eusofzyes. The former have the countly south of the river of Caubul, which is generally rocky or stony, but is not without some smooth and green meadows, particularly towards the river, where there are some beautiful spots shaded with tamarisk and the Indian tree called Seessoo. The country becomes rougher as one approaches the Indus. The villages are few, but large. The chief place is Acora, a large town with a neat mosque, and a handsome bazar built of stone.

The Khuttuks occupy a considerable extent of country ; their lands stretch from the Caubul river to the Salt range, a distance of about seventy miles. The breadth is about thirty-five miles. Their general boundary on the east is the Indus; though a branch of them possesses the town and territory of Mukkud on the Indian side; on the west they have the tribes of Peshawer, the Khyberees of the Range of $34^{\circ}$, and the Bungushes; on the south they have Bumnoo, and the Lohaunees of Daumaun. They are in two divisions, which are quite distinct; though the chiefs are cousins. 
The Khuttuks are probably over-rated by the Afghauns, who reckon the northern division at ten thousand, and the southern at fourteen thousand families. The Khauns in both divisions have great power over their clans, but the northern division is as much subject to the King as the tribes of Pcshawer; while the southern Khaun, secured by his mountains, maintains a greater degree of independence.

The people of the northern clan are praised for their honesty and their orderly conduct. They are tall, well-looking, and fairer than any of the tribes of Peshawer, but in their dress and manners they have a great resemblance to the people of India.

The country of the southern Khuttuks is various, but all mountainous; the southern part is the most so. It consists of stony, barren mountains, separated by deep and abrupt valleys, and is thinly inhabited by the predatory clans of Baurik and Saughur. It is impossible to imagine any thing more dreary than this part of the country; nothing is seen but rude and bare mountains, confusedly heaped together, nothing heard but the salt torrents that rush down the valleys. The scene is not rendered less forlorn by the straw hovels which are scattered by twos and threes on the summits of the mountains, and even these are met with but once or twice in a space of twenty miles. The savage inhabitants either fly from the traveller, or hover on the mountains, watching opportunities to attack him. The sight, however, is sometimes cheered by a patch of corn on the face of a bill, or by a green valley discovered far off from a height: the narrow valleys, though rough and dismal, are roman. VOL. II. 
tic; and the banks of the torrents are sometimes renclered pleasing by a clump of wild olives. Further north, the country is still crossed by ranges of high, steep, and rocky mountains; but among them are spacious and well cultivated plains. The principal of these are Maulgeen, Lauchee, and Teeree, which last place is the residence of the Khaun. They produce wheat and Bajree.

They export a great deal of rock-salt, dug from the Salt-range, principally in the neighbourhood of Teeree.

None of our party saw the Bauriks, except at a distance, nor had we any communication with them, but what arose from their attacks on our stragglers. We, however, learned, that though they were Khuttuks, they were independent on both Khauns, and lived in a state of anarchy.

The Khuttuks immediately to the north of the Bauriks, were dark men, dressed like some of the people in Hindostan, but ruder in their manners. In their intercourse with us, they were mild and inoffensive, and such, I hear, is their general character.

The clan of Bungush has the hills of the Khyberees on the north, the Khuttuks on the east and southeast, some of the Vizeerees on the south, and the Toorees on the west.

Their country consists of a long valley, widening into a plain about twelve miles in diameter. The valley is called Upper, and the plain Lower Bungush. The plain is fertile and well watered; the uncultivated parts are covered with dwarf palrn, but there are few trees, except in some pleasing gardens about Cohaut, the residence of the chief. This has been a neat little 
town, but has been reduced, by the distractions in the tribe, to the size of a considerable village. Upper Bungush is well watered, and productive in the bottoms, but the hills are steep and rugged.

Both the Khuttuk and Bungush countries have great variety of climate. Some parts of the hills are covered with snow as late as March, while others are scarcely whitened in the depth of winter; and some are never visited by snow. In general, the hills and valleys are colder as they are nearer the Solimauny mountains. The plains, though colder than Peshawer, have seldom, if ever, falls of snow.

The people of Lower Bungush, are very obedient to their Khaun and to the King, those of Upper Bungush less so.

They have something of the appearance of the tribes of Peshawer, but dress like Khyberees. The family of Bungush, which has made so great a figure in India, and from which are sprung the Nabobs of Furrukabad, is descended from a peasant of Upper Bungush.

West of Upper Bungush are the Toorees, inllabiting a continuation of the same valley. The country and produce are, of course, much the same. The people are independent of the King, and, what is surprising among Afghauns, they are Sheeahs; many of the Upper Bungush also belong to this sect.

Farther up the same valley, which continues to stretch west nearly parallel to the Koorrum, are the Jaujees, the inveterate enemies of the Toorees. Their valley runs up the steep side of the range of Solimaun, and is narrower, poorer, and colder than that of the Toorees. The sides of the valley are covered 
with pines; the chief animals are goats. The inha. bitants live in houses half sunk in the ground, wear Afghaun shirts of blanket, and burn fires day and night for the greater part of the year. One road from the Indus to Caubul runs up this long valley, and after passing the Jaujee country, issues through a defile in the highest ridge of the Solimauny range, into the high countries nortl-east of Ghuznee.

Neither the Jaujees nor Toorees are included among the Berdooraunees, and the following tribes are generally reckoned amongst those of Damaun; they differ, however, from those tribes in so many puints, that it will be more convenient to mention them here.

These are the Esaukhail, the Sheotuks, the Bunnossees, the people of Dower, and the Khostees; the three first lie to the south of the Khuttuk country, and the others to the south of the. Toorees; they have Damaun on the south.

The country of the Esaukhail stretches along the bank of the Indus for upwards of thirty miles. It is about twelve miles broad, and is bounded by high hills on the other three sides. It is a very fertile, well-watered, populous, and highly cultivated country. The water-courses are so numerous, and so broad and deep, as greatly to obstruct the roads. The villages are thickly planted, and most of them very large; most of the houses are thatched. Some large islands on the Indus belong also to the Esaukhail; many of them are under cultivation, and the rest are clearing and improving. 'The chief produce of the whole country is wheat.

'The Esaukhail disregard the royal authority; and 
have little government within themselves. They plunder weak travellers, and steal from those who are too strong to be plundered.

Beyond the hills on the west of the Esaukhail lies a plain, cultivated by a tribe called Sheotuk, respecting which I have no information.

Farther west, and higher up is Bunnoo, a very extensive plain, watered by the Koorrum, full of villages, and covered with corn fields. It is hot in summer, but in winter it has ice that will bear a man. It produces rice, wheat, barley, and Indian corn in abundance, and sugar-cane, tobacco, turmeric, ginger, and a few esculent vegetables; there are no fruits but melons, mulberries, citrons, lemons, and limes. The hills are bare, or only covered with bushes; on the plains are very large tamarisk trees, and some of the thorny bushes common in India. Among the wild animals are wild boars, wild sheep, and the animal called Pauzen in Persia; but the most extraordinary are the wild dogs, which exactly resemble tame ones, and go in packs of four or five couple.

The people are of various clans, not connected by blood, and without any common government. They live in perpetual contention. They pay some regard to the King's authority, and a great road passes through their country; but travellers have often a great deal of trouble, from the importunities of the people of every village, which it is not quite safe to reject.

Above Bunnoo, and divided from it by hills, is the long but narrow valley of Dower, which stretches up to the country of the Jadrauns, on the ridge of the Solimauny mountains. It is a populous country, full 
of walled villages, always at war with each other. There can be little or no government, since a powerful person can seize the children of a weak one, and sell them for slaves. They are remarkable for their disgusting vices, and indeed there is nothing to praise in their manners. Those of Bunnoo are not much better, and the Moollahs, as usual in such countries, have great power, which they do not fail to abuse.

To the north of Dower, between it and the Koorrum, lies Khost, a small country, peopled like Dower and Bunnoo, by many small clans of various descent. It lies as high as Dower, but is separated from it by hills. It is in obedience to the King, and is governed by one of its own chiefs, who acts as deputy to the King's Sirdar ; nevertheless it is torn by internal dissensions. The whole valley is divided into two factions, called the Tor Goondee and Speen Goondee (i. e. the black and white leagues), which are perpetually at war about the quarrels of one or other of their member's.

East of Khost is Drugye, a small country inhabited by a tribe called 'Tunnee, of which I know nothing but the name.

The hills which surround the four last countries, are inhabited by the mountain tribe of Vizeeree. 


\section{CHAPTER II.}

\section{EASTERN TRIBES-CONTINUED.}

DAMAUN, in its most extended sense, comprehends all the country between the Salt-range, the Solimauny mountains, the Indus, and Sungur in Upper Sind. I have already disposed of the part of it which lies to the north of the Koorrum and Gombela, and now proceed to the remainder. This may be divided into three parts. The plain of the Indus, generally inhabited by Beloches, and called Muckelwaud*; the country of the Murwuts ; and the plains and low hills (about the roots of the mountains) which constitute Damaun Proper.

Muckelwaud extends along the Indus for about one hundred and twenty miles. Its mean breadth is from twenty-five to thirty miles. It is a plain of hard smooth clay, quite flat, bare of grass, but sprinkled with bushes about a foot high, and still more thinly scattered with separate bushes of tamarisk, and of the thorny shrub called in India Kureel; with here and there a tree of the sort called Jaut, from fifteen to twenty feet high. The soil, when much trodden on, turns into a very minute whitish dust. It seems to be composed of the slime of the river, which in

* This is a Beloche or Hindkee name, little used, and perhaps unknown to the Afghauns. 
summer inundates this country for a great extent; at the same time the mountain streams, swelled by the melted snow, pour down and cover all the flats with water. It is seldom very deep, but it seems to lie long from the appearance of the ground, which is like that at the bottom of a drained pond; it is full of holes, and marked with channels by the water in all parts, and near the river these become considerable ravines.

The banks of the river are covered with thick jungle of low tamarisk, sometimes mixed with long grass, and sometimes with thorny bushes: abounding in wild boars, hog-deer, and all sorts of game. Round the villages are often large woods of dates, the only tall trees on the plain. Where there is cultivation, it is rich; but by far the greater part of the plain is waste, owing to the thinness of the population and the badness of the government. The southern part of the plain has most jungle; the north is sandy. Camels of the same kind with those of India are bred here in great numbers.

The principal town, Dera Ismael Khaun, is the residence of the governor, a Beloche appointed by Mahommed Khaun, the King's governor of this province, and Lya.

The people are Juts and Beloches, dark in complexion, and lean and meagre in form; their ordinary dress in summer is of dark coloured cotton; and in winter greyish or striped great coats of coarse woollen cloth, and quilted silk caps. They are perfectly submissive and obedient to the King and his representative.

The country of the Murwuts is composed of sandy and arid plains, divided by ranges of hills. It de- 
pends entirely on rain for cultivation, and in many parts the inhabitants are even obliged to carry water for several miles to supply their families.

Half the Murwuts are fixed and employed in agriculture. The rest wander about with their herds of camels; living chiefly in temporary huts of branches of trees, with a wall of thorns, and a roof of straw; some few have black tents of the worst description. They are tall, fair men, and wear a pair of loose trowsers, something thrown over their shoulders, and a handkerchief tied round their heads.

Their country is about thirty-five miles square, stretching from Bunnoo to Muckelwaud, and from near the foot of the Solimauny mountains to the short range of hills which separates Largee from the Indus. It is, however, thinly peopled. In the narrow slip between the short range of hills just mentioned and the Indus, live the small tribe of Khyssore.

Damaun Proper, which lies to the south of the Murwuts, and extends along the foot of the Solimauny mountains, there inhabited by the Vizeerees, Sheeraunees, and Zmurrees, is of equal length with Muckelwaud, but of various breadth, from eight or ten miles to thirty and upwards. It is inhabited by the Dowlutkhail and Gundehpoors, the Meaunkhail, Bauboors, and Stooreeaunees; which tribes, with the exception of the Gundelipoor, are included in the general name of Lohaunee. The Esaukhail, Murwuts, and Khyssores also are comprehended under this denomination.

Immediately to the south of the Murwuts, are the Gundehpoors and Dowlutkhails, of which the former 
are most easterly. Their country is like Muckelwaud, but better cultivated; particularly that of the Dowlutkhail, which in ordinary years employs all the water of the Gomul in its cultivation. The Gundehpoors have several large villages, of which the chief are Colauchee, Tukwaura, and Lonee. Tuck is the chief town of the Dowluthhail.

West of the Dowlutkhail are the 'Tuttorees, Meeaunees, Bitnees, and some other small tribes subject to the Dowlutkhail ; their country resembles that just described, but is more arid, and worse cultivated, and towards the west it is hilly.

The great road to Caubul runs past Tuck. It follows the course of the Gomul for a considerable distance, and is called, from one pass in it, The Road of Gholairee.

To the south of the Dowlutkhail, are the Meeaun khail, whose country is a little less flat than those I lave been describing, and whose chief place is Deraubund.

The chief road from Candahar issues from the hills at Zirkunnee near Deraubund. It goes by Zawa, through a mountainous and difficult country.

'To the south of the Meeaunkhail, is the country of the Bauboors, resembling that just described. The valley of Deheneh opens on it from the range of Solimaun, and pours out a stream which waters the cultivation; one road to Khorassaun passes through this valley, but it is not so much frequented as that of Gholairee.

To the south the Bauboors have the country of the Stooreeaunees, part of which is in the plain of $\mathrm{Da}$ maun, and like that of the Bauboors, but rougher to- 
wards the south, and far more dry and unfertile. The rest consists of the low range of grey sandstone, which rums parallel to the range of Solimaun, with part of the mountains and unproductive country beyond it. The chief town of the Bauboors is Choudwa, and that of the Stooreeaunees, Oormuk.

The produce of all these countries is the same as that of India; Bajra, Joarry, and wheat are the commonest grains. Many dromedaries are bred here, or at least by the tribes whose residence is partly in Damaun. They are much darker in colour than the common camel, have shorter and stronger limbs, and are far better calculated for work among hills. The grass of many parts of Damaun is excellent and abundant, and attracts many of the pastoral tribes during the winter season. The climate is then cool and agreeable, but the heat of summer is extreme.

The peculiarities common to the tribes of Damaun will be best shown by comparing them with the other division of the eastern Afghauns. 'They differ from the Berdooraunees in appearance, being large bony men, often fair, and always wearing long hair and beards. They have less of the look of Indians than the others, though their summer dress is nearly the same as that of India. Instead of the long wide shirt and cap of the Afghauns, they wear a close dress of white cotton, tied across the breast, and reaching a little below the knee; even in winter they wear turbans, but they are extremely large and loose, while those of the Indians are rolled close round their head, in a regular shape that has little grace or elegance. At that season, they also wear brown and grey woollen great coats, and posteens. Their houses, 
food, and habits of life resemble those of the Berdooraunees, but they live more on flesh, croot, and other produce of their flocks, and they have less form than many of the others, playing at all games, and allowing their women to appear in public without the least restraint. Many of them are pastoral, and almost all are merchants or carriers. Part of every tribe goes up every spring to Khorassaun; from this and other reasons, they have a greater mixture of the manners of that country than the Berdooraunees, though they retain strong marks of their original connection with Hindoostaun. They are generally simple and honest, less litigious than the tribes with which I am comparing them, less bigoted and intolerant, and less addicted to every kind of vice and debauchery.

Being still more remote from the seat of the royal authority, they are under little control from the government; and some of them seem, till within these fifty years, to have lived in as much anarchy as the Eusofzyes. But this has been corrected in the greater part of them by the election of temporary magistrates, invested with sufficient powers to preserve the public peace, but prevented by the short duration of their office from applying it to any purpose inconsistent with the freedom of the tribe. This magistracy is, indeed, the feature in the tribes of Damaun which most distinguishes them from the other Afghauns. It prevails among all these tribes except two, and also in the neighbouring mountain-tribe of Sheeraunee. It is also in use among the Ghiljies of Kuttawauz and the Nassers, but among no other people of whom I have information.

These magistrates are in some tribes elected by the 
Mulliks, in others by the heads of families. They are chosen for their personal qualities, the number of their relations, and their general weight in the tribe, and are armed with power to maintain order, and to punish the breach of it by fines, and in some tribes, even by corporal punishment. They are selected from each Khail in fixed proportions, which were at first designed to make up the number of forty (whence these officers are called Chelwashtees*), and they are under the authority of one chief, called the Meer of the Chelwashtees, who is elected in the same manner as the rest. The duty of the Meer of the Chelwashtees, is to enforce the lawful orders of the Khaun, and to settle disputes by his own authority, and punish disorders even in the person of the Khaun himself. The whole tribe is always ready to support him, to which they bind themselves by an oath, when the Clielwashtees are elected. It is an office of much power and considerable profit, as all the fines levied by the Chelwashtees are divided among themselves. The power of the Meer is not so absolute over the other Chelwashtees, as to enable him to gratify his own revenge, or pursue his own interest, at the expense of any of the members of the tribet. His office is generally annual, but sometimes he is only elected to preside over a march, or to command in a war, and his power ends with the occasion which gave rise to it. It is

* Chelwasht, in Pushtoo, signifies forty.

$\uparrow$ One tribe, the Meeaunkhail, has four Meers, all of equal power, but the inconvenicnce of this arrangement is sometimes felt from their dissensions, which it is necessary to remedy by an assembly of the Mulliks, who decide the dispute, and fine the Meer who is most in the wrong. 
sometimes allowed to expire, particularly in times of great tranquillity; but the disorders, which immediately commence again, soon make the tribe regret it, and determine them to restore it.

This magistracy does not exist in tribes where the Khaun has power enough to restrain the turbulence of the people. It is evidently intended to remedy the bad effects of the weakness of the hereditary chieis, and is the first step from a patriarchal governmerit to a republic in its usual form.

Damaun also furnishes an example of the transition from a patriarchal government to a military despotism; but as this change is not so easy and natural as the other, and as it was partly effected by external causes, it will require to be explained at greater length.

The Dowlutkhail had formerly a hereditary Khaun, who seems to have been held in great veneration by the tribe. By degrees, however, his authority grew weak, and the government fell first into the hands of the Mulliks, and afterwards of the people. The Dowlutkhail were now in the same state of anarchy that I have described among the Eusofzyes. They had no Chelwashtees, and all hereditary authority was completely disregarded. They were, however, obliged to nominate some person to manage their affairs with the King's Sirdar, and although this person had little power, he had more than any other individual, and was called the Khaun. He was chosen out of all the families of the tribe indiscriminately, but the choice sometimes fell on the descendants of the ancient Khauns. This was the case about the beginning of the last generation, when Kuttaul Khaun 
held the office, and so much ingratiated himself with Muddud Khaun, then Sirdar of Damaun, that he formed the design of making himself master of the tribe, by means of that chief's assistance. He at first assiduously courted popularity, and persuaded the Dowlutkhail to engage in the reduction of some little tribes in their neighbourhood.

He was entrusted with the command, and thus obtained a pretext for raising troops, which the contributions of the Dowlutkhail, and his exactions from the conquered tribes, gave him the means of maintaining. By these means he collected about three hundred Beloches and Sindees, and proceeded to build a fort, after which he thought himself secure, assumed the right to levy a revenue from the public Ryots, and began to tyrannize over his own tribe.

The tribe was at first struck with dismay, and submitted to his oppression, till at length he openly assumed the character of a sovereign, and ordered the people to pay their duty at his court every morning. Two of the Mulliks, to whom he first proposed this homage, refusing to comply, Kuttaul told them, that if they did not attend in the course of two mornings, their heads should be hung up over their own doors by the third.

The Mulliks withdrew, and hastily assembling the tribe and the Ryots, pointed out Kuttaul's designs, and engaged them in a conspiracy against him, which was confirmed by solemn oaths. Next morning the whole assembled in arms, and besieged Kuttaul in his fort. After a siege of three days, in which many people were killed, the water in the fort was exhausted, and the garrison was obliged to evacuate 
it ; and Kuttaul escaped on horseback, accompanied by some trusty attendants on foot. His flight was soon discovered, his enemies set off in all directions to pursue him, and eight of them took the road by which Kuttaul was flying. His attendants were soon fatigued, and one man alone remained with him. Kuttaul (says one of my informants) at this time wore a robe which was given him by a Dervise, and by the virtue of which he had obtained his present greatness ; in the precipitation of his flight this robe fell off, and immediately his remaining attendant became lame, and lagged behind; soon after his pursuers appeared; Kuttaul's courage had left lim with his robe, and he had recourse to humble entreaties for mercy ; some of his pursuers answered, that they were sworn, and others that he had never shown mercy to them, and at last one of them ran him through with a spear. Kuttaul's family were all seized. Gool Khaun, one of the principal conspirators, was put at the head of the tribe, and thus was baffled the first attempt at the subversion of the liberties of the Dowlutkhail.

Surwur Khaun, the eldest son of Kuttaul, was at this time only sixteen, but he was well educated, and endowed with great natural capacity. By the assistance of his mother, he effected his escape from prison, and, by a train of reasoning which could only have occurred to an Afghaun, he was led to go straight to Zuffer, the brother of Gool Khaun, and throw himself on his protection. He reached this chief's house, without discovery, and Zuffer, in the true spirit of Afghaun honour, immediately resolved to protect him, even at the risk of his brother's destruction. 
He accordingly fled with him to the Murwut country, and soon after began to intrigue at Caubul for assistance from the court. Their intrigues were soon successful, and Abdooreheem Khaun* was sent with four thousand men to restore Surwur to his father's office.

In the mean time, Gool Khaun had begun to be heartily tired of his magistracy. The tribe had turned into a turbulent democracy, over which he exercised a feeble and precarious, yet invidious authority; a sedition had broken out about the property left by Kuttaul, which Gool Khaun wished to appropriate to hinself. The Dowlutkhail began to murmur at his government; and one of them had drawn his sword on him, and asked, if he thought they had killed Kuttaul to make him their master? He was, therefore, equally terrified at the prospect of Surwur's success, and at the continuance of the democracy; and listened with pleasure to an overture which Surwur made to him, and which seemed to present the only safe retreat from his perilous situation. Accordingly, when Surwur approached, Gool Khaun's management, supported by the terror of the royal arms, disposed the Dowlutkhail to submit ; and Surwur taking a solemn oath to forget past injuries, they consented to receive him as their chief. This appearance of forgiveness was kept up till all the leading men had been got up together, when eighteen of them were seized and put to death. Gool Khaun was spared, but on a subsequent quarrel, Surwur put him also to death.

* The same who was afterwards declared King by the Ghiljieg.

VOL. II. 
His government was now established; all those that could oppose him, had been made away with, and nobody in the tribe had the courage to rebel. He continued to strengthen himself, and to put the murderers of his father to death as they fell into his hands, till twelve years ago, when all his enemies were extirpated, and his power was at its height. Since then he has governed with great justice and moderation; his steady and impartial administration is popular among the Ryots, but odious to the Dowlutkhail, whose independence it restrains.

Surwur now maintains about five hundred soldiers in his own pay, all the customs and the revenue derived from the Ryots are his, but he takes nothing from the Dowluthhail.

Like Kaussim Khaun of Deer, he cannot rest without reducing the free tribes around under his dominion. His chief designs have been against the Gundehpoors, who are his nearest neighbours. They are little less numerous than the Dowlutkhail, with all their Ryots, but Surwur can always impede their operations by bribing some of their Mulliks; and even when they engage heartily in a war, there is a great difference between villagers under the temporary authority of a Chelwashtee, and the troops of an established government like Surwur Khaun's.

The general jealousy of Surwur's designs, however, induces the Meeaunkhail and Baubers, usually the bitter enemies of the Gundehpoors, to unite with them in their struggles against that ambitious chief, and these means have hitherto been sufficient to keep his power within due bounds. 
The Dowlutkhail, with all their Ryots and conquered tribes, amount to eight thousand families.

The Gundehpoors have a hereditary Khaun, and hereditary Mulliks, but their power is very slight, and the tribe leads a lawless life, plundering strangers, stealing from the flocks of the wandering tribes which come into their neighbourhood, and continually quarrelling among themselves. Their weapons on these occasions are sticks of wild olive, so that murders are rare; but when one happens, it entails a deadly feud on the family, as is usual among the Afghauns. Their public affairs are conducted by an assembly of all the heads of families in the tribe, those who cannot attend, sending some of their family to represent them.

When they have a war with Surwur, all disputes are laid aside, a Chelwashtee is named, who sends a drummer round each village, to proclaim the time and place where the tribe is to assemble in arms, and any man that fails to attend is fined.

The Gundehpoors are great merchants, fifty or sixty go every year to Khorassaun, and four times as many to India; but this circumstance has little effect in civilizing them, and they have a degree of rudeness and brutality in their appearance and manners which $I$ never saw in any other tribe.

The Meeaunkhail are about three thousand families, of which number a fourth is composed of Bukh. teeaurees. Of this tribe, which is said to have come originally from the banks of the Tigris, and which is very numerous in the south-west of Persia, there are about seven or eight hundred families at Deraubund, and about five hundred at Murgha. Those at Derau- 
bund are completely incorporated with the Meeaunkhail. They have a share in their councils, gains, and losses, and are almost identified with the tribe. The others are connected with them, and, though not united with the Meeaunkhail, they send succours to that tribe in its wars in Damaun.

The Khaun of the Meeaunkhail has little power; he has an eighth of all customs collected at Deraubund, but no share in the collections from the Ryots. Public affairs are managed by a number of Mulliks, who take care to consult the interest and disposition of their Khails, but do not refer to them on every question that arises.

The Khaun has lately been endeavouring to imitate Surwur, but with little success; he too entertained some Beloches, built a fort, and began to encroach on his tribe; but he was opposed by the Mulliks, his power was circumscribed, and, by the last accounts, some farther attempt of his led the tribe to besiege him in his fort ; and he may, perhaps, ere now, have shared the fate of Kuttaul.

One half of the Meeaunkhail moves every spring to Khorassaun. No entire Kliail moves, but half of each; the Mulliks do not often move, but send a member of their family to command the moving division of the Khail. They have also Chelwashtees of their own, who have no authority among the settled people, except in time of war, when the Chelwashtees of both descriptions have a concurrent jurisdiction.

The moving Meeaunkhails, when in Damaun, encamp in the neighbourhood of Deraubund, and send the camels to feed on the shrubby plain of Muckel- 
waud. They pay a small sum on each camel to Mahommed Khaun for this privilege.

Their method of distributing the emoluments and duties of the tribe among its members, deserves to be noticed, as the same is probably observed by all the tribes of Damaun.

The tribe is divided into four parts, one of which is Bulkhteeauree, and three Meeaunkhail. The customs, after deducting the Khaun's share, are divided into four parts, and each division of the tribe gets a share, which is afterwards distributed among the subdivisions; but as the number of persons in each of these is not the same, the division is unequal. The revenue is assessed in the same manner, and eight Chelwashtees are taken from each division.

The Bauboors are a civilized tribe, much addicted to merchandise, and, on the whole, the richest and most flourishing of the tribes of Damaun.* Their Khaun has considerable power, and they are reckoned among the quietest and most honest of the Afghaun tribes. Their late chief was raised by Timour Shauh to the high office of Ameen ool Moolk, and enjoyed a large share of the confidence of that monarch. It is rare to see a man of any tribe but the Dooraunees elevated to such a station.

The Bauboors of the plain are about four thousand families.

A large division of the Bauboors lives in Sehra, beyond the mountains of Solimaun. It is contiguous to the country of the Sheeraunees, with whom those

* There are some persons among them who have fortunes of $30,000 l$, an immense trensure for that country, yet their property is quite secure. 
Bauboors are much connected, and whom they resemble in their manners and customs.

The Stooreeaunees were, till lately, all pastoral. Their country, indeed, afforded little temptation to agriculture. They conquered it not long ago from the Beloches of Damaun, and used to make it their winter station, and move their camps and flocks in summer to the lands of the Moossakhail Caukers. These migrations were rendered inconvenient or impracticable, by a quarrel which the Stooreeaunees had about twenty-five years ago with a clan of Caukers, through whose lands they were obliged to pass. Half the tribe on this sold its flocks, and betook itself to tillage. The other half endeavoured to keep up its ancient custom, but was soon compelled to imitate the rest; and after some disputes between the new settlers and the old, the whole tribe became agricultural, except two clans, which still adhere to a pastoral life, and move their little camps in spring to Spusta, on the south-western skirts of Solomon's throne.

Many of the Stooreeaunees, however, are still merchants and carriers, a life approaching to that of a wandering shepherd. Their carriage is mostly on bullocks and asses. Their numbers are about four thousand families. Their government agrees exactly with the model of an Afghaun aristocracy. The Cauzy, however, is so important an office, that complaints are made to him directly in the absence of the Khaun. The Cauzy is appointed by the Khaun, and the Moollah of each village by the Mooshir. The son of the last incumbent is preferred, if he is fit for the employment.

The condition of the Ryots is nearly the same in 
all these tribes. They are generally Juts and Beloches, with some Hindoos. They have no land, and they are under the person on whose estate they live, in the same manner as the Fakeers of the Eusofzyes. In Damaun, however, they cannot pass from one man to another, without their master's consent, which is generally obtained by a present, either from the Ryot, or from the person who wishes to receive him. They can, however, quit the tribe to which they belong whenever they please. Surwur alone endeavours to prevent his Ryots from leaving him.

The whole of Damaun is subject to the King, but his authority is loosely exercised, and he seems quite indifferent to every thing but his revenue. The tribes are bound to furnish him with a body of horse, for which he generally takes a commutation in money. $\mathrm{He}$ also levies the Jezzeea, or tax on Hindoos, throughout Damaun. The tribes of Damaun seem attached to the King so long as he does not interfere with them, but they look with horror on the prospect of being brought under his government, and changing their present independence for submission to a master.

An attempt was once made by Mahommed Khaun to reduce the Meeaunkhail ; and he took many of their villages, and forced their Khaun to fly. The fugitive Khaun went to his inveterate enemies the Gundehpoors; and, although the tribes have many wars among themselves, and are all jealous of Surwur, the whole, including the Murwuts and Esaukhail, rose on this occasion as one man, made Surwur their chief, and did not desist till they had compelled Mahommed Khaun to abandon his design. 
There are still to be found in Damaun some families of the tribes of Sooree and Lodi, to the first of which belonged the dynasty of Ghore, at one time the most powerful in Asia; the second for a long time gave Kings to Hindoostaun.

Besides the tribes I have mentioned, all Damaun and Muckelwaud are filled in winter with camps of Solimaunkhails, Kharotees, Naussers, and other wandering tribes, who come there to avoid the rigour of their native climates. Those who have camels move into Muckelwaud, but those with sheep remain in Damaun. 


\section{CHAPTER III.}

MOUNTAIN TRIBES.

I AM now to speak of the tribes which inhabit the range of Solimaun; and, as J propose to begin from the south, I ought first to describe the Zmurrees (who inhabit that part of the mountains which is to the west of the Stooreeaunees) ; but, as that tribe closely resembles the Sheeraunees, I shall proceed to describe the latter, respecting whom I am better informed. I must, however, notice that the Zmurrees are allowed to be exempt from the habits of rapine, for which the Sheeraunees are so remarkable.

The Sheeraunees inhabit the mountains north of those of the Zmurrees. Their country overlooks that of the Bauboors and Meeaunkhails, and they have the Vizeerees on the north: their western boundary will be mentioned hereafter.

Great part of this country is occupied by the lofty mountain of Tukhti Solimaun, and the hills which surround its base. Many parts of it are nearly inaccessible; one of the roads is in some places cut out of the steep face of the hill, and in others supported by beams inserted in the rock; and with 
all this labour is still impracticable for loaded bullocks.

The population is scattered in villages. of from twenty to forty houses, through the valleys and the lower parts of the mountains. They cut out the sites of their houses in the slopes of the hills, so that on three sides the earth forms the lower part of the wall. Each cottage contains but one room, and has only one entrance, which is closed at night with a branch of a thorny tree. Even in winter they have nothing to sliut out the cold ; but sleep on black carpets round the fire, wrapt up in their sheep-skin cloaks. Their forests furnish them with plenty of fire-wood, and their houses are lighted with branches of a particular sort of fir which burns like a torch.

The Sheeraunees are generally of middling stature, thin, but stout, hardy, and active. They have bold features, grey eyes, high cheek-bones; and their general appearance is wild and manly. The dress of the common Sheeraunees consists of a coarse black blanket tied round their middle, and another thrown over their shoulders. They wear sandals, the soles of which are made of bullocks' hides, rudely prepared by steeping in the ashes of the tamarisk tree; and their dress is completed by a few yards of white cotton cloth loosely twisted round their heads. The dress of the richest is not much finer than this. The chief is thought magnificent, because he dresses in Moultaun sillk.

Their usual food is bread made of Indian corn, butter, and croot. This last, however, is a luxury seldom enjoyed but by those who keep sheep. Wheaten bread is only produced on festivals. The 
flesh principally eaten is mutton. They never kill beef; but when a bullock happens to die, they cut its throat with the usual Mahommedan ceremonies, and eat it without scruple, though the flesh of animals that die of disease is strictly prohibited by the Koraun.

They eat wild olives fresh from the tree, and dried olives, which they are obliged to boil. They also eat wild pomegranates (though they are very sour and harsh), the seed of the Julghoozeh pine, and several sorts of berries which grow wild in their mountains.

The Sheeraunees marry late. They differ from the other Afghauns in this respect, that the father of the bride gives a dowry, instead of receiving a price for his daughter. The women only work at domestic employments, and at reaping the harvest.

Money is very scarce among them, their trade being principally carried on by barter.

They have no domestic servants nor slaves, and no artificers : about a dozen of Hindoos keep shops, and sell grain, cloth, treacle, tobacco, clarified butter, and a few of the coarsest manufactures of the plains; and a small number of settlers from Damaun practise the trades of smiths and weavers.

The principal employment of the Sheeraunees is agriculture, which is carried on in the valleys; some places under the hills produce grain without watering, but all the rest of their lands are irrigated by means of dams thrown across the hill streams. There is no man in the tribe but the chief (and the Moollahs) who does not labour.

They have two harvests, one of which consists of red rice, Indian corn, Moong, and tobacco. It is 
sown in summer, and reaped in autumn: when it is off the ground, they sow wheat and barley, which is cut in the beginning of summer.

Theil common stock consists of bullocks, but there are some shepherds who live scattered in small hamlets over the summits of the mountains, and some even in tents. Their bullocks are very small, always black, and without humps. 'They have a few goats and some asses; but no mules, buffaloes, or camels. There are not twenty horses in the whole country.

The chief of the Sheeraunees is called the Neeka, (which in Pushtoo means the grandfather). He has very great authority in his tribe, which is partly derived from lis being the cliosen head of the oldest family, and partly from the belief of the Sheeraunees, that he is under the immediate guidance and protection of Providence. He has a large estate, and consequently employ:s many people in husbandry, but he lhas no domestic servants. He receives a lamb annually from every man in the tribe who has sheep, and a calf from those who have many cattle. No force is employed to realise this tax, but it is readily paid, from the conviction of the people that some great misfortune (the death of a child, for instance) will fall on every person who refuses to pay.

Though men often redress their own injuries by mere force, yet the Neelsa is the only regular dispenser of justice. He hears the parties, and, after saying a prayer, decides the cause by the inspiration of the Divinity. His order is always obeyed, from the dread of supernatural punishment.

The Sheeraunees have also Chelwashtees, but they seem intended rather to supply the place of the 
Neeka in distant parts, than to strengthen his power. They are appointed by the Neeka, and act under his orders. The Sheeraunees have little internal dissension.

There is a Moollah in every village, who receives a tythe of the produce of its lands and flocks. The simplicity of the Sheeraunees is shown in a strong light by one of the functions of this priest, which is to sew the shrouds for the dead. A great many of the Sheeraunees learn to read the Khoraun, though none but Moollahs learn to read Pushtoo, and none Persian. They are very punctual in their prayers, but apparently feel little real devotion.*

The Sheeraunees are at war with all the tribes that pass through their country in their annual migrations. They may, indeed, be said to be at war with all the world, since they plunder every traveller that comes within their reach ; and besides, make incursions into parts of Damaun with the inhabitants of which they have no quarrel. While I was in their neighbourhood, they stopped the body of a Dooraunee of rank, which was going through their country to be buried at Candahar, and detained it till a ransom had been paid for it.

All, however, agree that their faith is unblemished, and that a traveller who hires an escort of Sheeraunees, may pass through their country in perfect security.

* I have seen a Sheeraunee performing his Namauz, while some people in the same company were talking of hunting ; the size of deer happened to be mentioned, and the Sheeraunee, in the midst of his prostrations, called out that the deer in his country were as large as little bullocks, and then went on with his devotions. 
The Neeka commands in their wars, and before any expedition all the troops pass under his turban, which is stretched out for the purpose by the Neeka and a Moollah. This they think secures them from wounds and death; and they tell stories of persons who have lost their lives from neglecting or disdaining this ceremony. Their arms are a matchlock and a sabre.

Among the hills to the west of the range of Solimaun, are Gosa, inhabited by the Moossakhail Caukers, which lies west of the Zmurrees; Sehra, a high barren plain among mountains, inhabited by the hill Bauboors; and still farther north are Spusta, and the country of the Kuppeep and Hurreepaul tribes; on the west of all these countries are hills which separate them from Zhobe.

Spusta is a wavy plain, covered with wild olives. It is high, cold, and barren, and is inhabited in summer by the Murhails, a pastoral tribe, who move in winter into Damaun. They live entirely in tents, and have 'the manners of the other shepherd tribes. Though poor, they carry on some little trade; their stock is sheep, goats, asses, and a few oxen, used only for carriage. Their Khaun is powerful, though under the Neeka of the Sheeraunees, and their Moollahs have authority enough to punish offences against the Mahommedan Ritual. The tribes of Hurreepaul and Kuppeep resemble the Sheeraunees, of which tribe they are branches; and their residence is in the hills and valleys at the western base of Tukhti Solimaun.

The extensive country of the Vizeerees lies to the north of that of the Sheeraunees, and stretches up to the northward for one hundred miles, till it reaches 
MANNERS AND HABITS OF THE VIZEEREES. 79

Sufaid Coh; the low hills which separate the little country about Khost and Bunnoo, have been mentioned as belonging to the Vizeerees; but, from the parallel of Sirufza to near the source of the Koorrum, they share the mountains with the Jadrauns, the latter having the west face of the range, and the Vizeerees the east.

The greater part of their country consists of mountains covered with pine forests, but containing some cleared and cultivated spots. The lower hills are bare, or only covered with bushes and low trees.

The Vizeeree country is little visited, except by passengers, who shun the inhabitants as much as they can ; and I have found it impossible to meet with a Vizeeree out of his own country. The following account is derived from travellers ; it is superficial, and may be incorrect.

The Vizeerees have no general government ; they are in little societies, some under powerful Khauns, and others under a democracy; they are all remarkable for their peaceable conduct among themselves, and have neither wars between clans, nor much private dissension. Though they are notorious plunderers, the smallest escort secures a traveller an hospitable reception through the whole tribe. They are particularly remarkable for their attacks on the caravans, and migratory tribes to the west of the pass of Gholairee. No escorts are ever granted or applied for there; the caravan is well guarded, and able to deter attacks, or to fight its way through. No quarter is given to men in these wars; it is said that the Vizeerees would even kill a male child that fell into their hands; but they never molest women; and if 
one of that sex wanders from her caravan, they treat ber with kindness, and send guides to escort her to her tribe. Even a man would meet with the same treatment, if he could malke his way into the house of a Vizeeree; the master would then be obliged to treat him with all the attention and good-will which is due to a guest. The Vizeerees who are fixed, live in small hamlets of thatched and terraced houses; in some places (about Kannegoorrum for example), they live in caves cut out of the rocks. Some of these rise above each other in three stories, and others are so high as easily to admit a camel. But most of the tribe live in black tents, or moveable hovels of mats, or tempoiary straw huts; these go up to the high mountains in spring, and stay there till the cold and snow drive them back to the low and warm hills. Their principal stock is goats; they also breed many small but serviceable horses; and what would not be expected in such a country, they are fond of horsemanslip. The Vizeerees are said to be tall and muscular, of fair complexions and high features. Their whole dress is a high conical black cap, a loose great coat of black blanket, fastened round the waist with a girdle of the same material, and sandals of straw rope, or untanned leather. From this attire, and from the descriptions which are given of their shaggy hair and beards, and their hairy limbs, their appearance may be conceived to be wild and terrible. Their arms are generally an Afghaun knife and a shield; and every man carries a matchlock, at the use of which they are very expert. Their own country affords materials for these arms; it abounds in iron ore, which the Vizeerees work up into ar'ms, and export to 
the plains. Their manners are haughty, and their voices loud, distinct, and commanding; but they are gentle and good-tenpered in their intercourse with their guests, and with each other. Such is their veracity, that if there is a dispute about a stray goat, and one party will say it is his, and confirm his assertion by stroking his beard, the other instantly gives it up without suspicion of fraud.

Their amusements are listening to songs (for they never deign to sing themselves), and dancing a sort of Pyrrhic dance, in which they go through some warlike attitudes, and leap about, flourishing their swords.

The food of the Vizeerees is the flesh of sheep, oxen, or camels, which they eat half raw, with croot and unleavened bread of the worst description.

The women are not required to labour. They wear a long thick shift of red cotton, with sandals like the men, and have as many gold and silver ornaments as their husbands can 'afford. A most extraordinary custom is said to prevail among them, which gives the women the choice of their husbands. If a woman is pleased with a man, she sends the drummer of the camp to pin a handkerchief on his cap with a pin which she has used to fasten her hair. The drummer watches his opportunity, and does this in public, naming the woman, and the man is immediately obliged to marry her, if he can pay her price to her father.*

[* Besides Dr. Honisberger, who passed through their country with the Johaunee caravan, the Vizeerees have been visited by $\mathrm{Mr}$.

VOL. II, 
The Jadrauns have the Vizeerees on the east, the Kharotees and the country dependent on Ghuznee on the west, and the Jaujees on the north. Their dress and manners are said to be like those of the Vizeerees. Towards the Koorrum, they cultivate some of the inferior sorts of grain, but towards the Kharotees, they wander with their goats through the thick pine forests, and are (as a Kharotee observed of them), in appearance and habits of life, more like mountain bears than men. They are not an extensive tribe, and their country is never visited by travellers. They have wars with the Kharotees, and plunder travellers on the road from Caubul through Bungush, near the pass of Peiwaur. I need scare say that they are never to be met with out of their hills.

The countries along the western side of Tulkhti Solimaun, which accompany those which I have been describing in their progress towards the north, do not call for any particular notice. To the north of the Hurreepaul is the country near the junction of the Gomul and Zhobe, sometimes pastured on by wandering Caukers. North of it is Wauneh, a low plain situated on the hills that slope down to the valley of the Gomul. It is an open tract, inhabited by a small tribe called Dumtauny, and much frequented in summer by shepherds of the Solimaun Khail and Kharotee tribes; some of the

Masson, who is well known for his discoveries of coins and antiquities of the Bactrian and other dynasties. It is much to be regretted that his extensive and enterprising travels have not been communicated to the public.-1838.] 
tribes dependent on the Dowlutkhail, also drive up their flocks to Wauneh in winter. North of Wauneh is Oorghoon, the country of the Fermoollees; and then a tract belonging to Kharotees, and other clans of Ghiljies, of all which I shall hereafter have occasion to speak at large. 
WESTERN AFGHAUNS, DOORAUNEES, CITY OF CANDAHAR, TEREENS, AND BARAICHES.

THe countries hitherto described consist of flat and low-lying plains, or of strongly marked ranges of mountains. The plains are hot and fertile, generally populous, and almost all inhabited by fixed residents. The mountains are high and rugged, the tops covered with forests, and the sides pierced by deep valleys : inbabited by tribes separated from each other, and only known to the rest of the world by their assaults on strangers who penetrate to their haunts, or by their incursions into the neighbouring plains. Those which we are now to review have an opposite character. They are mostly high and bleak downs, interspersed with moderate hills, in some places desart, and in others ill-cultivated; bare, open, bet- ter fitted for pasturage than for the plough; and much inhabited by shepherds in moveable camps. The characters of the hilly and plain countries run into each other; nor is there any more marked line of separation between the characters of their inha. bitants. Both are simple, honest, and peaceable; and though there is a difference in the degree in which those qualities are possessed by different tribes, 
there are none who would be remarkable among Asiatic nations for the want of them. The western tribes, especially those of Khorassaun, understand Persian much more generally than the Eastern ones do Hindostaunee; and their dress, arms, and habitations, while they retain their national peculiarities, approach to those of Persia. The character of the people, however, is essentially different from that of the Persians; and perhaps the difference is more striking than that between the Eastern Afghauns and the Indians, though that also is great. Scattered over an extensive country, the Western Afghauns are too distant from each other to acquire either the vices or the habits of strife which belong to a crowded population : each horde drives its flock over its extensive lands, or the still wider range of unappropriated pasture; without a rival, and often without a neighbour. In the same manner, each society of the fixed inhabitants cultivates the banks of a river, or the ground commanded by a caureez, at a distance from all other agricultural people; and individuals of those societies are prevented from quarrelling about their shares by the abundance of waste land, and the facility with which the surplus of their population can be provided for in pasturage. This thinness of the population, while it retards the progress of the arts of life, is doubtless equally effectual in checking the increase of the vices which abound in populous countrięs; and accordingly we find among the Western Afghauns a sort of primitive simplicity, which reminds us rather of the scriptural accounts of the early ages, than of any thing which has been observed by moderns in nations where society is still in its in- 
fancy. In some parts of this tract the character of the people seems to have undergone some change, in consequence of the impression made on the governments of their tribes by the neighbourhood of the monarchy. Among the Ghiljies and Dooraunees, the hereditary chiefs of the tribes have successively founded great kingdoms, of which the latter still subsists. Among the Dooraunees, the heads of clans also form the nobility, who enjoy the great offices of the court, the state, and the army; and they appear in the double character of patriarchal chiefs, and of wealthy and powerful noblemen, deriving command and influence from the King's authority, and from their own riches and magnificence. In this situation many of the republican institutions of the tribes disappear, but other circumstances contribute to preserve the importance of the clansmen, and to prevent their sinking into entire dependence on their lord. A degree of order and tranquillity is secured, superior to what is ever attained in the democratic tribes, at the same time that all the peculiar virtues of those tribes are preserved; and on the whole, the effect of this kind of government on the people who live under it, appears to be more favourable than any one we shall have to consider.

Though the kingdom has passed away from the Ghiljies, it has still left its traces, and the effect of the former high stations of the Khauns is still observable among them; it is not, however, sufficient to prevent anarchy; and a popular government seems gradually to be forming, which will take the place of the old aristocracy in maintaining the public tranquillity. 
The principal feature in which the Western Afghauns differ from the Eastern, is formed by the numerous pastoral tribes. These, though they have all some common points of resemblance, such as their living in tents, and moving with the seasons, differ among themselves in other particulars which will appear in the details. The difference principally relates to the distance between their summer and winter stations, and to the degree in which they combine agriculture with pasturage.

The summer station is called Eilauk, and the winter station Kishlauk, two words which both the Afghauns and Persians have borrowed from the Tartars. The tents almost universally used among the Afghanns are of a kind of black blanket, or rather of coarse black camlet, such as is used for the same purpose in the greater part of Persia. It is called Kizhdee in the Afghaun language, Seeahchaudur in Persian, and Karraooee in 'Turkish : both of these last phrases mean "black tents," the term generally given to them by Europeans.

The tents of the tribes that move little are always larger and better than those of the very migratory people.

The latter have often fine tents, which they leave at the stations where the climate is most severe, carrying lighter ones on their journeys to the places where shelter is less required.

It must not be inferred that all the Western Afghauns are shepherds: on the contrary, although the space given up to pasture may be much more extensive than that employed in agriculture, yet the number of citizens and villagers must, I should 
imagine, considerably exceed that of the wandering hordes.

Many parts of the country, particularly round the cities, are as highly cultivated as any part of the world : in remoter districts some well cultivated tracts are to be met with; and even the most deserted regions afford occasional marks of the industry of the husbandmen.

In treating of this country I shall begin at the west (where the greatest contrast will be found to what has been already mentioned), and proceed eastward, till, as I approach the division formerly described, some traces will appear of the manners already known to the reader as peculiar to the eastern Afghauns. In pursuance of this plan, I shall begin with the Dooraunees and their southern neighbours, the Baraiches and Tereens; and then stretch east with the Ghiljies, till I reach the valley of the Caubul river and the mountains of Solimaun. The Caukers, whose lands extend from those of the Tereens to the mountains just mentioned, will end all the part of my account which is connected with geography; and the pastoral and unsettled tribe of Nausser will conclude the description of the Afghauns.

The length of the country of the Dooraunees may be loosely said to be 400 miles; and except in the north-west, the general breadth is from 120 to 140 miles.

It is bounded on the north by the Paropamisan mountains, inhabited by the Eimauks and Hazaurehs; on the west it has a sandy desart of various breadth, beyond which are the Persian dominions: on the south-west it has Seestaun and a desart, which sepa- 
rates it from Belochistaun; its southern boundary is formed by Shoraubuk and the hills of Khaujeh Amraun, which separate it from the Tereens and Caukers; and on the east it has no natural boundary, but joins to the lands of the Ghiljies, into which the valley of Urghessaun, part of the Dooraunee territory, runs for a considerable extent. The number of square miles in the Dooraunee country is probably superior to that in England; but it includes some large spaces of desart, and the inhabited country is probably little superior to Scotland in extent, and inferior in population. 'The population is by no means evenly spread, nor is the face of the country through all its extent the same. The part which lies west of longitude $63^{\circ}$ east (a slip not exceeding seventy or eighty miles in breadth), is situated between the sandy desart already described and the Paropamisan mountains, and partakes of the nature of both of those tracts. In general it consists of arid and uncultivated plains, crossed by ranges of hills running westward from the Paropamisan mountains into Persian Khorassaun; but though its general appearance be waste and barren, most parts of it supply water and forage to the pastoral hordes that frequent it; and it is not destitute of many wellwatered and pleasant valleys, and some fertile plains surrounded by mountains. In those tracts are many villages, but the only town in this part of the country is Furrah, on the river of that name, which was once a place of great extent, and is still a considerable walled town. This appears to be the ancient Parra, by which name indeed the Afghauns still distinguish it. 
The southern part of the tract I lave been describing is by no means so mountainous as the northern; and it seems not improbable that it may once have been a fertile region, and may have been encroached on by the desart, like the contiguous country of Seestaun. This opinion is supported no less by the magnificent ruins which are still to be seen, than by the recorded accounts of the fertility and extent of Seestaun, to which the tract in question is said to have belonged.*

From longitude $63^{\circ}$ east, a tract of very considerable extent stretches eastward for upwards of two hundred miles to the meridian of Candahar. Its general breadth is near 100 miles. Its boundaries are ill defined; for, on the north, the hills sometimes run into the plain, and the southern parts of the inhabited country are not easily distinguished from the desart on which they border. The whole extent approaches to the nature of a desart. The southern parts are sandy, and the northern consist of hard earth, mixed sometimes with rocks, and even with low hills; but all is equally unproductive: scarce a tree is to be found in the whole region, but the plains are covered with low bushes, of which the principal are those called jouz and tirkheh by the Afghauns; and two lower bushes from which kali is produced. Yet this discouraging abode is by no means destitute of inhabitants. The banks of the Furrah rood, the Khaush rood, and other streams, are well cultivated, and produce wheat, barley, pulse, and abun-

* Seestaun is said to have contained 120,000 ploughs. For an account of the ruins seen by Captain Christie, see Mr. Kinneir's Geo. graphy of Persin. 
dance of excellent melons. Even at a distance from the streams, some patches of cultivation are watered by means of caureezes; and scarce any part of the country, especially of the north, is so bad as not to afford herbage and water in the cool season to numerous camps of Dooraunees, who drive their flocks in summer into Seeahbund, the country of the Tymuneès. There are villages among the cultivated lands, but none of them are large; and certainly the mass of the inhabitants are scattered over the face of the country in tents. Some parts of this country also appear to liave lost a great deal of their fertility. The soutl-eastern part of it contains the brooks of Dolnree and Cuddenye, which within the last century were considerable streams throughout the year, but which are now dry, except.in spring.

The banks of the Helmund, though within the tract of which I have described the limits, must be entirely excepted from all the above observations. That river, even after it has left the hills, continues to be accompanied on each side by a stripe of fertile and cultivated land, the southern part of which forms the singular country of Gurmseer. 'This district occupies a hollow stretching along both banks of the Helmund from the neighbourhood of Girishk to Seestaun. It seems in ancient times to have been an extensive territory, and to have been ruled by an independent prince; but it is now confined in general to a quarter of a mile on each side of the river, and its whole breadth nowhere exceeds two miles, beyond which the sandy desart extends for many a day's journey. The Gurmseer itself is moist, and sometimes even marshy; many parts of it are cultivated, 
and afford plentiful returns to the husbandman. In those spots are castles and fortified villages, but the greater part is covered with herbage, rushes, and tamarisk bushes, among which are many camps of shepherds.

To the northward of the desart tract last described is a hilly region dependent on the Paropamisan range. It differs greatly from the countries we have hitherto been considering, being formed of ranges of hills, including fertile plains. The hills are covered with woods of the shnee tree, the wild almond, wild fig, wild pomegranate, the oriental plane, and the walnut tree. The plains are rich, are well watered by caureezes and springs, and produce abundance of wheat, barley, and rice, together with madder and the artificial grasses. The wild trees of the.plains are tamarisk and mulberry, and a few willows and poplars, but the numerous orchards are composed of all the fruit trees of Europe. Many pastoral camps are also found in this tract, probably in the hilly parts of it; and though it contains many good villages, yet a great proportion even of the agricultural inhabitants live in black tents. The climate is always temperate, but in winter the northern parts suffer from cold. Zemeendawer, the most westerly part of this division of the country, deserves particular mention on account of its fertility. It is joined on the north-west by Seeahbund, a mountainous region abounding in cool and grassy valleys, which, though it belongs to the Tymunee Eimauk, requires to be mentioned here, as affording a summer retreat to so large a proportion of the Dooraunee shepherds.

The country round Candahar is level, naturally of 
tolerable fertility, irrigated both by water-courses from the rivers and by caureezes, and most industriously cultivated. It in consequence abounds with grain, and its gardens contain good vegetables and excellent fruit, besides melons, cucumbers, \&c. which are cultivated in the fields, as is usual in Khorassaun. Madder, assafcetida, spusta (luceme) and shuftul (a kind of clover) are also abundant. The tobacco of Candahar has a great reputation. The country near the hills is probably the most fertile, and that round the town best cultivated; the country to the west is sandy at no great distance from the city, and that to the south becomes dry and unproductive within a march of Candahar: that to the east is fertile and much better cultivated than the rest of the valley of the Turnuk, which will hereafter be described.

The principal feature of the south-east of the Dooraunee country, which alone remains to be described, is the chain of Khojeh Amraun. This, though not a mountain of the first rank, is high enough to bear snow for three months, and to be cold all the year. It is chiefly inhabited by shepherds, who belong to the Achukzye clan of Dooraunees. Its summits and sides abound in shnee trees and a sort of gigantic cypress, called by the Afghauns obushteh. Judging by the wildness of the inhabitants, and their predatory habits, one would suppose these hills very difficult of access; but, though steep on the south-east side, I believe they slope gradually down to the country on their nortli-west, and are cultivated in different places from near the summit to the foot. The Dooraunee country, in the direction of this range, begins to the north-east of Shoraubuk, where it is sandy and 
unproductive. Further north and east, it has wellwatered spots among barren hills. Of this nature is Rabaut, a tract covered with tamarisk, supporting many flocks, and yielding some grain. Still further to the north-east the sand ceases, and is succeeded by a rugged and stony country, in which are some streams and some plains of tolerable fertility. The most remarkable of these is Murgha, where is the castle of Ahmed Khaun Noorzye, and which is watered by the stream of Cuddenye: most of this tract is well adapted to pasture. On the southern side of the range of Khojeh Amraun, opposite to Murgha, lies Toba, an extensive country, the west of which belongs to the Achukzyes, while the eastern part, which extends almost to Zhobe, belongs to the Caukers. To the north of Murgha lies Urghessaun, so called from the river which waters it. It is a valley of tolerable fertility between high hills. It is full of tamarislss, is partially cultivated, and contains a considerable number of castles belonging to Baurikzye Khauns, but by far the greater part of the inhabitants are pastoral. It ends to the east in a range of hills, which separate it from a high plain, still inhabited by Dooramees, and watered by the upper course of the Urghessaun, and by the Sauleh Yesoon, from which stream the country receives its name. It is well suited to pasture, but little cultivated.

The wild animals of the Dooraunee country ar'e wolves, hyænas, jackals, foxes, hares, and many kinds of deer and antelope. In the hills there are bears and leopards, and in the Gurmseer (on the Helmund) are many wild boars and goorkhuls, or wild asses. The wild birds are eagles, hawlss, and some 
other large birds of prey. Swans (in spring), wild geese, and wild ducks, storks, and cranes, owls, crows, magpies, pigeons, cupks*, sooseest, quails, \&c. \&c. The tame animals are camels, buffaloes, (but not numerous, and chiefly to be found on the Helmund and near Candahar,) horses, mules, and asses; black cattle, sheep, and goats, dogs and cats. The tame birds are fowls, pigeons, and rarely ducks and geese.

Such is the country of the Dooraunees, a tribe which still rules the whole of the Afghaun nation, whose government has been obeyed from the neighbourhood of the Caspian Sea to that of the Ganges, and the effects of whose power have been felt over Persia and Tartary, and even at the remote capital from which I write these pages. $\ddagger$

The Dooraunees were formerly called the Abdaulees, till Ahmed Shauh, in consequence of a dream of the famous saint at Chumkunee, changed it to Dooraunee, and took himself the title of Shauh Dooree Dooraun. I have been able to learn little or nothing of their early history : some accounts describe the mountains of Toba as their most ancient abode; more numerous traditions represent them as having descended into the plains of Khorassaun from the mountains of Ghore, which belong to the Paropamisan group, but leave it uncertain whether that tract was their original seat, and by what causes their emigration was occasioned. $\$$ The tribe is divided into two

* The same bird which is called chicore by the natives and fireeater by the English in Bengal.

t A bird of the same species with the last, but smaller.

\$ Poona, the capital of the Marattas.

Hanway, with great probability, though I know not on what authority, states them to have been settled to the east of Heraut early in the ninth century. 
great branches, Zeerulk and Punjpaw'; but those divisions are now of no use whatever, except to distinguish the descent of the different clans : that of Zeeruk is reckoned by far the most honourable. From these branches spring nine clans, of which four belong to Zeeruk, and tive to Punjpaw.

ZeERuk.

Populzye

Alleklroyze

Baurikzye, Atchilzye
PunjaAw.

Noorzye,

Alizye,

Iskhaukzye,

Khougannee,

Maukoo.

The Populzye is the most eminent of these clans, as it gives a King to all the Afghauns. The royal family is sprung from the little division of Suddozye, which had long been the Khaunkhail, or head family, of the Populzyes, and indeed of all the Dooraunees. It is probable that the Suddozyes were the eldest branch of the Dooraunee tribe, and in consequence possessed their superiority from the first formation of the society; but the earliest testimony of their enjoying it, is a patent from one of the first of the Suffavee Kings of Persia, appointing the chief of the Suddozyes to the command of the Abdaulees. The privileges they enjoyed were greater than the patent of a King could ever have obtained from such a tribe. Their persons were sacred, no retaliation nor punishment could be inflicted on any of them, except by a member of their own family : nor could even the head of the Abdaulees himself, pass sentence of death upon a Suddozye. This circumstance, and the King's being the head of them, have made the Suddozyes be con- 
sidered as a separate clan, though a branch of the Populzyes.

Their principal residence is in the neighbourhood of Sheher Suffa, in the lower part of the valley of the Turnuk. Some also reside at Candahar, and a considerable colony has found its way to the distant city of Moultaun, to which they have probably been driven by some political events in their tribe.

The rest of the Populzyes chiefly reside in the hilly country north of Candahar. They are a numerous clan, generally reckoned by the most moderate natives at twelve thousand families.* Though some of them are shepherds, by much the greater number are engaged in agriculture. They are reckoned the most civilized of the Dooraunee clans. The grand vizier ought always to be a member of the Baumizye division of them, and it is from among the Populzyes that most of the great officers of state were chosen by Ahmed Shauh.

The next clan to the Populzye, which it far exceeds in numbers, is the Baurikzyes. This great clan inhabits the country south of Candahar, the valley of Urghessaun, the banks of the Helmund, and the dry plains which that river divides. Those near Candahar, and many of those in Urghessaun, and on the Helmund, are led by the fertility of their soil to agriculture, and the industry of others has even produced caureezes and cultivation in the midst of the desart; but the greater part of the tribe is composed of shepherds. They are a spirited and warlike clan, and, as Futteh Khaun is

* I give the numbers of the clans to show their relative importance. and not from any confidence in their individual accuracy.

VOL. II. 
now their chief, they make a much more conspicuous figure than any other tribe among the Afghauns. At present, the grand vizier, and almost all the great officers of the state, are Baurikzyes, and they owe their elevation to the courage and attachment of their clan.

Their numbers are not less than thirty thousand families.

The Atchikzyes were a branch of the Baurilkzyes, but were separated by Ahmed Shauh to reduce the formidable numbers of that clan. They are now under a separate chief, and entirely unconnected with the clan from which they spring. They inhabit the range of Khojeh Amraun, from the Lora to the Cuddenye, together with some of the adjoining plains, and are the wildest of the Dooraunees: their only employments are pasturage and plunder.

The Noorzyes are equally numerous with the Baurikzyes; but as they are scattered through the hills in the west, and the desart tract in the south, of the Dooraunee country, they by no means make so great a figure in the Afghaun nation. They are however a martial tribe, and those on the frontier towards Seestaun find constant exercise for their courage and enterprize in the mutual depredations in which they are engaged with the Beloche borderers. Almost the whole of them are shepherds, who spend the winter in the grassy spots which are found in the barren region they inhabit, and who retire in the middle of spring to Seeahbund.

The Alizyes inhabit Zemeendawer, and are mostly agricultural. Their numbers are rated at fifteen thousand families. 
The Allekkozyes are only ten thousand families. In their country and habits they resemble the clan last mentioned, from which they are separated by the Helmund.

The Iskhaukzyes live between Zemeendawer and the desart, and their country shares the characters of those on which it borders ; being hilly and fertile on the north, and flat and barren on the south. The people are employed in equal numbers on agriculture and pasturage. Their numbers are about ten thousand families.

The Maukoos and Khougaunees are small clans, who have no distinct lands ; many live at Candahar, and some are mixed with the Noorzyes. They used to have separate chiefs, but none have been appointed since the commencement of the present troubles in the state, and the clans are likely soon to be extinguished.

Though the lands allotted to the Dooraunee clans are separated and defined as above described, the clans by no means live unmixed with each other, like different tribes; on the contrary, men of one clan frequently acquire lands by purchase or by grants in the midst of another ; and some countries, as the Gurmseer, and the country round Candahar, are inhabited by almost all the clans in nearly equal proportions.

The whole population of the Dooraunee country may safely be estimated at 800,000 souls. It may perhaps approach to a million, but on such subjects it is difficult to speak with confidence. The Dooraunees themselves must be reckoned considerably more than half. It is universally asserted that Naudir Shauh numbered the tribe, when lie was fixing their 
lands and the proportion of men they were to furnish, and found them to consist of sixty thousand families; but, supposing such a census to have been made, it must have fallen much under the real numbers, as many persons, of the shepherds especially, must have been overlooked. The Dooraunees have certainly been in a flourishing situation since that time, and their circumstances have been very favourable to the increase of their population; so that the number of 100,000 families must now be considered as within bounds.

The government of the Dooraunees differs widely from that of the republican tribes I have already described, though it is evident that it has originally been framed on the same model.

The difference seems chiefly to be occasioned by the more immediate connection of the Dooraunees with the King, and by the military tenure on which they hold their lands. The King is the hereditary chief of the tribe, and this circumstance derives peculiar importance from the veneration in which the Dooraunees hold the house of Suddozye. He is also their military commander, and that more effectually than is the case in the other tribes. With these last, the military service which they owe to the crown is an innovation, introduced after they had occupied their lands, which they had conquered or brought under cultivation without aid from any external power, and without an acknowledgment of dependence on any superior : but the lands of the Dooraunees were actually given to them on condition of military service, and the principal foundation of their right to the possession is a grant of the King. The whole of their 
own country had been conquered by Naudir Shauh, and part of it was restored, with a large portion of that of the Ghiljies, on the express condition that they should furnish a horseman for every plough; and the performance of this engagement to the Persian monarch has ever since been exacted by the Afghaun dynasty which bas succeeded to his rights and pretensions.

The officers of the horse thus raised are the civil magistrates of the country allotted to maintain them,*

* So far the system resembles that adopted by the Emperor for his Hungarian frontier, and thus described by Mr. Townson ; "This long tract of land which surrounds Hungary on the south and on the enst, has about 520,000 inhabitants, the fifth part of which is military. It is divided into five principal divisions, as those of the Banat; of Croatia, of Dalmatia, of Sclavonia, and of Transylvania: these are again divided into provinces or regimental districts, and these into companies. As this is quite a military government, there are no civil mngistrates, but military ones : a regimental district may be considered as a county, and it has, instead of a lord lieutenant, a colonel ; and a district of a company, which may be considered as a processus, instead of a judex nobilium, a captain; and so likewise with the inferior officers, who supply the places of inferior civil magistrates." This plan, however, was adopted by the Hungarian government as a check to the encroachments of the Turks. Its object was to secure the zealous service of a warlike body particularly interested in the defence of the frontier. That of the Dooraunee government, on the contrary, was merely taken up as a convenient way of paying part of the army for general service. For these reasons, the government of Hungary is strict in providing for the actual residence of every holder of land : it also provides for the actual service of the holder's sons, and it forbids the transfer of the land without express permission. The Dooraunee government, on the contrary, shows no anxiety on any of these heads, which it lenves to the discretion of individuals. Residence is no object, and transfer does not signify, where all the population is military, and where there is none of that discipline which renders it so desirable to retain an old soldier. The government by tribes among the Dooraunees, constitutes the principal contrast 
and this system is reconciled to that of the Oolooss government, by making the military divisions correspond to those of the tribe, and by maintaining all the relations of the hereditary chiefs; thus the head of a clan commands the troops which it furnishes, and the subordinate officers are the Mullilks and Mushirs of khails and subdivisions under him, each commanding the contingent of his own portion of the Oolooss.

It is obvious that this military command must render the power of the Sirdars greater than that of the chiefs of other tribes, and their authority is further strengthened by the wealth and splendour which they derive from the situations about the court, where all great offices are in the hands of Dooraunees. As these advantages are conferred by the King, it might be expected that the Sirdars would be kept by them in a state of entire subservience to the government; and this is rendered the more natural, as the people hold their lands directly of the Crown, and consequently have not that dependence on their chiefs which characterized the feodal system. The independence of the Sirdars is, however, maintained by the influence over their clans, which they derive from their birth, and from the patriarchal institutions of the Afghaun tribes. This is at once sufficient to establish their importance, for the dynasty of Sud-

between them and the land-holders on the Hungarian frontier, and, even with them, the character of an officer is not quite sunk in that of a hend of a tribe. The heads of Dooraunee clans are called by the military title of Sirdar (general), while those of the other tribes have that of Khotun, (chieftain) : the former referring to their rank in the IKing's army, and the latter to their luereditary relation to their tribe. 
dozye is mainly upheld by the Dooraunees, and the crown would be transferred without a struggle from one member of it to another by a general combination of that tribe; consequently, the King is, in a great measure, dependent on the good will of the Dooraunee chiefs, and is obliged to conciliate that order by bestowing on it a large portion of power and honour, though in reality he views it with jealousy, and is continually employed in indirect attempts to undermine it. The powers of the parties are pretty nearly balanced. In disputed successions, the chief may often lead his clan to the candidate for whom he is best disposed, yet no Dooraunee clan has ever risen against the family of Suddozye on aceount of the personal injuries or disgust of its Sirdar : on the other hand, though the King has been known to exercise the power of nominating men not descended from the head family to be Sirdars, and even of appointing a man of one clan to be Sirdar of another; yet in these cases he seems to have pushed his authority further than the Dooraunees were willing to submit to : chiefs so appointed were obeyed with reluctance, and the clan waited impatiently for a rebellion, headed by a Suddozye, to throw off their new chief, and the King who appointed him, and to receive their hereditary Khaun with open arms. The clans near Candahar probably look up most to the King, while those who inhabit remote and unfrequented countries (as the Noorzyes and the Atchikzyes), are more attached to their Sirdars. Even in those tribes the Sirdar derives a great part of his power from the King, but he exercises it subject to less control than the chiefs of tribes near the royal residence, and he is less apt 
to be eclipsed, or set aside, by the immediate intervention of the sovereign,

The effect of this competition is highly favourable to the happiness of the people. It is of great consequence both to the King and the nobles to obtain popularity; and consequently, although particular circumstances have invested the government of the Dooraunees with powers unknown to those of other tribes, yet there are few communities where the wishes and opinions of the governed are more attended to. Among other privileges, they are exempt from all payment of revenue, itself the great source of oppression in Asiatic nations. No troops are allowed to maraud in their lands, or indeed in any part of Afghaun Khorassaun. The only shape in which they feel the government, is in its demands for the service of their fixed contingent of troops, and in its interposition to preserve the public peace, by which they are themselves the principal gainers.

Each of the great clans of the Dooraunees is governed by a Sirdar, chosen by the King out of the head family. The subdivisions are under Khauns appointed out of their head families by the Sirdars; and the Mulliks and Mushirs of the still smaller divisions are, in most cases, elected from the proper families by the people, subject to the Sirdar's approval ; but in others, appointed by the Sirdar, with some regard to the wishes of the people. When different subdivisions live in one village, they have separate quarters, aud each lives under its own Mullik or Mushir ; but none of the dissensions between quarters, which have been shown to rage among the Eusofzyes, are ever known here, and all live in harmony, like people of one family. 
The powers of the various chiefs among the Dooraunees, though very efficient as far as they go, are simple, and the occasion for exercising them is limited, compared to those of tribes more independent of the King. There are no wars with other tribes, nor disputes between clans of the same tribe, in which the chiefs can show their importance by directing the operations of their people; nor have their clans any of those subjects for consultation and debate, in which the chiefs of independent tribes display their policy and their influence. The general tranquillity is secured by the King's government, and the duties of the Sirdars and Khauns are confined to the adjustment of disputes between individuals. When these cannot be made up by the mediation of the elders, they are brought before the Jeerga by the Mullik; and its decrees are, if necessary, supported by the Sirdar. Mulliks of other quarters, and even of other villages, sometimes assist at these Jeergas.

Though the spirit of revenge for blood is no less felt here than elsewhere, yet retaliation is much repressed by the strength of the government. The Dooraunees, however, never put a man to death for killing another in expiation of a murder previously committed: as long as the murders on both sides are equal, they think natural justice satisfied, though they banish the second murderer, to preserve the quiet of their own society. If the offended party complains to the Sirdar, or if he hears of a murder committed, he first endeavours to bring about a compromise, by offering the Khoon Behau, or price of blood; but if the injured party is inexorable, the Sirdar lays the affair before the King, who orders 
the Cauzy to try it ; and, if the criminal is convicted, gives him up to be executed by the relations of the deceased. This last mode of adjustment through the Sirclar is the most usual among towns, and in civilised parts of the country. Private revenge prevails most in the camps of shepherds, who wander in the hills and desarts, remote from all seats of authority and of justice ; but even there disputes seldom go beyond regular encounters with sticks and stones; and throughout all the Dooraunees, blood is scarcely ever shed in domestic quarrels. It is looked on as flagitious to draw on a countryman, and a tradition even exists of an oath imposed on the people of the tribe by the Suddozyes of ancient days, which bound them for ever to abstain from the use of swords in disputes among themselves.

Civil disputes are either settled by the elders of the village and the friends of the parties, by the arbitration of Moollahs, or by the decision of the nearest Cauzy. When the Sirdar, or other chief, is absent from the tribe, his duties are performed by a Naib, or deputy, of his own appointing, generally a brother or a son, but always a near relation. When the King is not in the Dooraunee country, his place is supplied by the prince who has the government of Candahar.

I have mentioned that the Dooraunees are partly pastoral, and partly agricultural ; this, of course, makes a difference in the babits and manner of life of different parts of the tribe. I shall first describe those who live in villages, taking my observations generally from the neighbourhood of Candahar.

It is a common form of the Dooraunee villages to have four streets leading into a square in the centre. 
There is sometimes a pond, and always some trees in this space; and it is here that the young men assemble in the evenings to pursue their sports, while the old men look on, and talk over the exploits of their youth, or their present cares and occupations.

The houses are constructed of brick, burnt or unburnt, and cemented with mud, mixed with chopt straw. The roofs are sometimes terraces laid on beams, but far more frequently are composed of three or four low domes of brick joining to one another. An opening is left in the centre of one of the domes, and over it is a chimney made of tiles, to keep out the rain. This sort of roof is recommended by its requiring no wood for rafters, a great consideration in a country where timber is so scarce. Most dwelling-houses have but one room, about twenty feet long and twelve broad.

There are two or three out-houses adjoining to the dwelling-house, built exactly in the same manner, and designed for the sheep and cattle ; for the lay, straw, grain, firewood, and implements of husbandry. Most houses have a little court-yard in front of the door, where the family often sit when the weather is hot. The room is spread with Gulleems,* over which are some felts for sitting on. The villages are generally surrounded with orchards, containing all the fruittrees of Europe, and round them are scattered a few mulberry trees, poplars, planes, or other trees, of which the commonest are one called Marandye, and another tree, with broad leaves, called Purra.

The shops in the Dooraunee villages are generally

* A kind of woollen carpet without nap, generally striped with different shades of red, or with red and some otlier colour. 
very few, and are never kept by Afghauns. For instance, in the village of Bulledee, near Candahar, which consists of about two hundred houses, there are three shops, where grain, sugar, and other eatables, are sold; one fruit-shop; and one shop where knives, scissors, combs, looking-glasses, and such articles are to be had. There is a carpenter almost in every village, as well as a blacksmith, and sometimes a weaver or two; the nearer to the city, the fewer are the artisans. Cloths are made by the women, who sometimes also weave blankets. There is at least one mosque in every Dooraunee village, and often more; the Moollah, who reads prayers in it, receives a portion of grain from every man in the village, besides what he earns by teaching children to read.

In most villages, and generally in the square (where there is one), is a public apartment, where all the men of the village assemble to converse and amuse themselves.

The chief occupation of all the villagers is agriculture. They sow their great harvest (which is of wheat, barley, and some other grains) in November, and reap it early in June : another harvest, chiefly of pulse, is then sown, and is reaped in the end of September. Melons, cucumbers, \&c., are also sown in June, and the artificial grasses in spring; all is irrigated.*

Their stock is chiefly bullocks for agriculture, of which every family has three or four pair : most men have sheep, which supply them with mutton, milk, and wool ; they have also some cows for milk. The sheep

* The seasons vary with the situation of the lands : those I have mentioned refer to Canclahar. 
are driven to the hills or wastes in the morning, and return at night. Some, who are more given up to pasturage, go out in summer with their flocks to the hills, where they live in tents ; in winter they find abundance of herbage in the plains. The beasts of burden most used are asses, but camels are always used for long journeys, and many are kept to be hired out to merchants. Horses and mules are also bred, particularly in the country of the Iskhaulszyes.

The better sort of Dooraunees have their lands cultivated by Buzgurs, by hired labourers, or by slaves. They act themselves as superintendants, often putting their hand to any work where they are wanted, like middling farmers in England. The poorer Dooraunees are often Buzgurs, but seldom labourers, that employment falling chiefly to the Taujiks, or to the Afghaun Humsauyehs.

A large proportion of the husbandmen live in tents, which are either of black blanket, as will be soon described, or of thick black felt supported by twigs twisted together, and bent over, so as to form an arch. The agricultural families, who live in tents, do not move beyond their own lands, and that only for the benefit of a clean spot, or to be near the part of the grounds where the cultivation of the season is chiefly carried on.

Almost every village surrounds, or joins to, the castle of a Khaun. These castles are encompassed by a wall of no strength, and generally intended more for privacy than defence. 'They, however, have sometimes round towers at the corners; and, when inlabited by great lords, they sometimes mount swivels on the walls, and have a small garrison, besides the 
relations and immediate retinue of the Khann, who, in general, are their only inhabitants. They are built in a square, the inside of which is lined with buildings; on one side is the great hall and other apartments of the Khaun, on the others are lodgings for his relations, his servants, and dependents, storehouses for his property, and stabling for his horses. The open space in the centre is usually a mere bare court-yard, but, in some instances, it contains a little garden. The principal gardens are always on the outside of the castle, and the flocks, and herds of horses or camels, which belong to the Khaun, are kept at distant pastures, and attended by servants who live in tents.

At one of the gates of every castle is a Mehmaunkhauneh, or house of guests, where travellers are entertained, and where the people of the village often come, to talk with the strangers, and hear the news.

The Khaun's apartments are furnished according to the fashion of the country, and though, as may be expected, the poorer Khauns live in great simplicity, yet the richer have rooms painted with various patterns, and spread with fine carpets and felts.

The Khauns themselves (I here speak of the common run of Khauns over the country) appear to be sober, decent, moderate men, who, though very plain, have still horses and servants, and are superior to the common Dooraunecs in dress and manners. They are generally an industrious and respectable set of men, attached to agriculture, and anxious to improve their lands, treating their inferiors with mildness and good-will, and regarded by them with respect and esteem. 
The title of Khaun is never given in public documents, but to the nobles who hold it by the King's patent, but the courtesy of the country gives it to the description of men I have been mentioning; as the title of Laird (Lord) in Scotland is given to a class of country gentlemen, who, in their rank in society, and their relation to the common people, bear no slight resemblance to the petty Khauns of the Dooraunees.

Before I quit the agricultural part of the Dooraunees, I ought to say something of the Taujiks, and other people, not belonging to the tribe, who, for the most part, reside with this class of the community.

The Taujiks bear a large proportion to the Dooraunees themselves.

Neither they nor the Afghaun Humsauyehs pay any tax, or are subject to the servitude to which the Eusofzyes have reduced their Falseers; they are not considered as equals, but the superiority claimed by the Booraunees, rests rather on their more noble descent and superior courage, than on any legal advantage they possess in the society.

The Afghaun Humsauyehs mix well with the Dooraunees, and as they never come among them overburdened with property, they are in a situation rather to profit by their hospitality, than to suffer by their rapacity.

The pastoral part of the Dooraunee population is chiefly to be found in the hilly tract between Heraut and Seestaun, and in the waste plains of the south. The people to the south-east of Candahar are also much employed in pasturage. There are other shepherds in many of the agricultural parts of the 
country, as there are husbandmen in those most devoted to pasture.

The moving tribes north of Candahar remain in the plains in winter, and retire to the hills in summer; those south of Candahar find a refuge from the heat in the hills of Toba; but the greatest emigrants are the tribes beyond the Helmund, who almost universally retire to Seeahbund and Bauyaghuz, in the Paropamisan mountains, before the middle of spring. After that period, scarce an inhabitant is to be met with in the plains. This emigration lasts for three or four months.

All the shepherds, with the exception of those on the Upper Helmund, live in Kizhdees, or black tents, which it is therefore necessary now to describe more particularly.

The Kizhdees of the common people are from twenty to twenty-five feet long, ten or twelve feet broad, and eight or nine feet high. They are-supported by a row of poles, generally three in number, and are pitched like common tents, in such a manner that the lowest part of the cloth which forms the roof, is four or five feet from the ground. The space is closed by a curtain, which hangs down from the edge of the roof, and is tied to tent-pins driven into the ground for the purpose. They are composed of coarse black camlet, sometimes single and sometimes double, which affords excellent shelter from the weather; the threads of the blanket swell as soon as they are wetted, so that its texture, naturally close, soon becomes impervious to rain.

The tents of Khauns, and of people in good circumstances, are of a superior description to this, 
being large enough to contain a numerous assembly, and so high as easily to admit a camel. Many of the Dooraunees line their tents with felt, which makes a much more comfortable residence in winter, and the floors of all are spread with Gulleems and felts. The tents of the common people are divided by a curtain into an apartment for the men, and another for thc women; and the poorest Dooraunees have at least one other tent for their sheep. Besides these, the poor erect temporary huts of basket-work, plastered with mud, for their sheep; and some of the Humsauyehs themselves inhabit similar dwellings. A common Kizhdee costs about two tomauns, or four pounds sterling.

The camps consist of from ten to fifty tents ; one hundred is a number very unusually large. They pitch in one or two lines, according to their number, and the nature of the ground. The Mullik's tent is in the middle of the line. To the west of every camp is a space marked out with stones, which serves for a mosque, and at some distance there is often a tent for guests.

A large camp is called a Khail, and a small one Keellee.

The above is their order of encampment in winter, when they pitch their camps around the castles of their chiefs. At that season they drive their flocks to a distance to pasture, and ele out their green forage with hay, straw, vine leaves, and other dry fodder. In the cold parts of the country they often trust almost entirely to this sort of food, and to such plants as the sheep can browse on among the snow. The greater part of the shepherds of those tracts, VOI. II. 
however, descend into the plains in winter, or retire into sheltered valleys, and feed their flocks on the sunny sides of the hills.

In-spring, when grass is plenty in all places, and the season for lambing render's it inconvenient to drive the flocks far from home, the shepherds break up their camps and disperse over the country, pitching by twos and threes, wherever they meet with an agreeable spot. Many such spots are found in the beginning of spring, even in the worst parts of the Dooraunee country, and the neighbourhood of the high hills, especially affords many delightful retreats in sequestered valleys, or in green meadows on the borders of running streams.

The delight with which the Dooraunees dwell on the description of the happy days spent in these situations, and the regrets which are excited by the remembrance of them when in distant countries, can only be believed by those who have seen them; while the enthusiasm with which they speak of the varieties of scenery through which they pass, and of the beauties and pleasures of spring, is such as one can scarce hear, from so unpolished a people, without surprise.

Though these camps are so small, and situated in such retired situations, we must not suppose that their inhabitants live in solitude. Many other camps are within reach, and the people belonging to them often meet to hunt, by chance or by appointment. Sheepshearing feasts and ordinary entertainments, also bring men of different carnps together; and they are, besides, often amused by the arrival of an itinerant tradesman, a wandering ballad-singer, or a traveller who avails himself of their known hospitality. 
This sort of life is perhaps seen in more perfection in the summer of Toba, which belongs to the Atchikzyes. That extensive district is ciiversified and well wooded. The grass is excellent and abundant, and is mixed with a profusion of flowers, and the climate is so mild as scarcely to render shelter necessary either by night or day. This agreeable country is covered in summer with camps of Dooraunees and Tereens, who all live on the most friendly terms, visiting at each other's camps, and making frequent hunting parties together. They often invite each other to dinner at their camps, where the strangers repair in their best clothes, and are received with more ceremony and attention than is usual in the more familiar intercourse of immediate neighbours. On these occasions companies of twelve or fifteen assemble to dine in the open air, pass the evening, with part of the night, in games, dancing, and songs, and separate without any of the debauchery and consequent brawls which so often disturb the merriment of the common people in other countries. Their fare at that period is luxurious to their taste ; lamb is in season, and croot, maust, $\dagger$ curds, cream, cheese, butter, and everything that is produced from milk, are in abundance. Thus they pass the summer; at last winter approaches, snow begins to fall on the tops of the hills, and the shepherds disperse to their distant countries, to Urghessaun, to Pisheen, to Rabaut, and to the borders of the desart.

* The hardened curd already described.

$\dagger$ A sort of soft curd, which is slightly acid, but very agreeable to the taste. It is called dhye in India, and yourt in Turkey. 
Yet this peaceful and social disposition must not be inagined to animate the pastoral tribes on all occasions: those who inhabit the frontier towards Persia and Belochistaun, are fierce and active in their border wars. Even the Atchilzzyes, whose country is the scene of the tranquil and simple life I have been describing, are the most warlike and by far the most predatory of the Dooraunee tribe. This may seem inconsistent, but it is by no means the first instance of the union of a predatory and martial spirit with the innocence of a pastoral life, and even with a great degree of sensibility to the charms of romantic scenery and of social enjoyment. All Greece, in the age of Homer, furnished examples of the same apparent inconsistency. The Scottish border, in modern times, bore the same character, and the songs of its inhabitants alternately exult in the pillage and havoc of a foray, and breatle the softest and tenderest sentiments of love and purity. Even the Arcadians themselves, from whom we draw all our notions of the golden age of slsepherds, were a warlike race; and it was the mutual depredations of the little cantons into which Arcadia was divided, that at length drove her shepherds from their flocks and mountains to the safety of walled towns.*

To return to the composition of Dooraunee camps ; each camp is composed of men of one family, but there are in each a number of Humsauyehs, chiefly Caukers and Ghiljies. They have sometimes Taujiks, and more frequently Eimaulss, among them, who work as smiths, carpenters, and (metayers) buzgurs.

* I hope I shall not be understood to represent the Afghauns as at all resembling the Arcadians of pastoral poetry, 
The existence of these last in the camps may seem surprising; but all the moving hordes of Dooraunees cultivate a little ground, and they leave the charge of it to their buzgurs while they are absent from their own country. They even carry on a little husbandry at their eilauks or summer stations, but it does not seem to go much beyond raising melons, and a very small quantity of grain.

They all give a share of the increase of their flocks to the per'son in whose lands they encamp while out of their own country.

Far the greatest part of their flocks consist in sheep. They also keep goats, the numbers of which are great or small in proportion to the sheep, as the country is more or less hilly. In some parts onethird of the flock is composed of groats, in others they only keep a few goats to lead the sheep in grazing. Those near the desart, and those in easy circumstances, have camels on which they carry their tents and baggage; they sell the males and retain the females for breeding. The poor use bullocks and asses. Almost every man has a horse, and a great number of them keep greyhounds. The men have very little employment: one man, or two at most, are enough to take care of all the sheep of a camp, and even this is often done by a shepherd hired from among the Humsauyehs. Their little cultivation is carried on by Buzgurs, who are generally Humsauyehs also. Their busiest time is in spring; the flocks are then sent out to feed at night, and require twice the usual number of shepherds ; it is then, also, that they have their lambs to take care of, and their sheep to shear; but these labours are of no long 
duration. They shear the sheep again in the end of autumn. During their marches, which never exceed five or six miles, they have their cattle to load and drive, and their tents to pitch; but all in-door work is done by the women, who also make their clothes, and often weave their guleems, the camlet for their tents, and a showy kind of rug, which they use for covering horses. Most of their caps, boots, \&c. \&c. are purchased in the towns, whither some of the shepherds repair occasionally to sell their croot and clarified butter, their felts and blankets, and their lambs and he-camels.

Having detailed the points in which the inhabitants of villages and those of camps differ from each other, I resume the description of those which they have in common.

The people about towns, most of those in villages, and all those of the shepherds who are in easy circumstances, wear a dress nearly resembling that of Persia; which, though not very convenient, is remarkably decorous, and, with the addition of a beard, gives an appearance of gravity and respectability to the lowest of the cornmon people.* See the frontispiece.

* It consists of a cotton shirt, over which is a tunic sitting close to the body; with skirts reaching half way down the leg, which come quite round, and cross each other in front. This is called the ulkhaulik. It is generally made of chintz, and that of Masulipatam, which comes from India by the circuitous channel of Persia, is most admired: over this is a tunic called the kubba, shaped very like the other, and either made of a coarse brown woollen cloth, or of a very strong cloth made of cotton, and called cudduk. This upper garment is sometimes of a bright colour, but generally clark and bottle-green is the commonest colour. It is tied across the breast, but the strings are concealed, and a row of covered silk buttons 
rood.

The poorer Dooraunees, particularly among the shepherds, wear the wide shirt and mantle represented in the frontispiece to the first volume.

The poor only change their clothes on Fridays, and often only every other Friday; but they bathe once a week at least, and their prayers require them to wash their faces, beards, hands, and arms, many times in the course of every day.

The little Khauns over the country wear the Persian dress; their kubbas or coats are made of silk, satin, or a mixture of silk and cotton called gurmsoot, and sometimes of brocade; and they all wear shawl girdles, and a shawl round their cap. Their cloaks also are of broad cloth, often red, or of sillk of different colours.

The food of the rich is nearly the same as that of

runs down one side of the front, with a row of silk loops on the other, though at much too great a distance to button. The sleeves are closed with a long row of buttons and loops, which run up the inside of the arm. They wear wide, coloured trousers of silk or cotton, short stockings in winter, and Persian shoes, which are round and broad at the toes, and narrow towards the heels: they are shod with iron, like the German boots, and the inner part on which the heel rests has a piece of wood to fit it, covered with a thin plate of ivory, in which some figures are inlaid in black. The slooes are made of brown leather, well tanned.

The head-dress is a cap, about six inclees high, made of quilted silk or chintz: there is another way of malking this cap, besides that represented in the frontispiece.

A loongee or coarse shawl, is always worn round the waist as a girdle, and the old men often twist another loongee round their caps like a turban.

Many people of the lower order wear the ulkhaulik, or under tunic only, without the kubba, and all wear a cloals over the rest of their dress: in summer it is made of some light cloth, and in winter of sheep skin or felt. 
the same class in Persia, fat, highty spiced pilaws, various linds of. ragouts, and joints of meat stewed in rich sauces. Most Europeans, I think, would relish this cookery, but I have heard the mixture of sweel things with all sorts of dishes in Persia complained of, and I suppose the same objection applies here. Their drink is sherbet, which is made of various fruits, and some kinds of it are very pleasant.

The food of the common people is bread, croot, clarified butter, and occasionally flesh and cheese. The shepherds and the villagers, in spring, also use a great deal of curds, cheese, mill, cream, and butter. ${ }^{*}$ They also eat vegetables, and a great deal of fruit. Those in camps only get melons, but the settled inhabitants have all our best English fruits.

The shepherds eat much more butcher's meat than the husbandmen: even these have it occasionally, and no entertainment is ever given without flesh. Mutton is the kind most generally eaten. They eat it fresh in summer, but in winter they have a sort of smoke-dried flesh which they call Laund, or Lundye. They almost universally boil their meat, and make a very palatable soup, which is eaten with bread at the beginning of their dinner. When they vary from this standing dish, they stew their meat with onions, or make it into pilaw. Some of the shepherds have a way of baking mutton like that used in the south-

* The clarified butter keeps long without spoiling. The cream is either common cream, or a preparation called Kymauk, which is made from boiled railk, and is something like clouted cream. The bread is generally leavened and baked in ovens, of which there is one in every liouse and tent. They also eat unleavened bread toasted on an iron plate lilse what is used for oat calkes in Scotland. 
sea islands. They cut the meat into pieces, and inclose it in the skin of the sheep, which they put into a hole in the earth, and surround with redhot stones. Meat thus dressed is said to be juicy and well tasted.

I describe the dress and food in so much detail, because it is applicable, with some modifications, to all the western Afghauns.

The appearance of the Dooraunees is prepossess- 。 ing ; they are stout men, with good complexions and fine beards, of which they always encourage the growth, though the young men clip them into shape; they always shave a stripe down the middle of the head, and most men crop the remainder ; some, however, wear long curls, and some of the shepherds allow their hair to grow to its full length all over their heads.

There is great variety of feature among the Dooraunees; some have round plump faces, and some have traits in no way strongly marked; but most of them have raised features and high cheek bones. Their demeanour, though manly, is modest, and they never discover either ferocity or vulgarity.

They never go armed, except on journeys, when they carry a Persian sword, and perhaps a matchlock; shields are out of use, and bows are only kept for amusement. Those in good circumstances have plate and chain armour, carbines with firelocks, pistols, and lances. They often have a long bayonet, of a peculiar construction, fixed to their matchlocks.

They have no feuds among themselves, nor with 
their neighbours, except in the south-west, and, consequently, their only opportunity of showing their prowess is in national wars, in which their reputation has always stood very high. The strongest, and by far the most efficient body in the regular army, is composed of the contingent of this tribe, and in an invasion of their country, the safety of the monarchy would depend on the voluntary courage of the Dooraunees.

The Dooraunees are all religious; there is not a village, or a camp, however small, without a Moollah and there probably is rot a man (except among the Atchikzyes) who omits his prayers. Yet they are perfectly tolerant, even to Sheeahs; except among those very Atchikzyes, who are themselves so indifferent to the forms of religion. The Mooliahs in the country are quiet and inoffensive people. Few of the lower order can read, but almost all the Dooraunees understand and speak Persian, and many can repeat passages from the most celebrated poets in that language, and in their own.

Their customs relating to marriage are nearly the same as those of the other Afghauns. They usually marry when the man is eighteen or twenty, and the girl from fourteen to sixteen.

The employments of the women have been alluded to. They are almost as regular as the men in their prayers. Their husbands treat them kindly, and it is not uncommon for a woman to have a great ascendancy over her husband, and even to be looked up to in the family for her wisdom. A lady of this kind assumed the absolute command of a caravan 
with which Mr. Foster* travelled, and that gentleman profited in no small degree by her protection.

The men and women live and eat together when the family is by itself, but at their parties they are always separate. Their visitors, their sports, and all their meetings are apart.

The men often assemble in the mosque, the Hoojra, or the Mehmaunkhauneb, where they smoke, take snuff, and talk of their crops, their flocks, the Jittle incidents of their society, or of the conduct of the great, and the politics of the kingdom. Hunting and shooting are also favourite amusements, and it is among the Dooraunees and other western Afghauns, that the games and sports which have been so fully described, are by far the most practised and enjoyed. They dance the Attunn almost every evening, and they never have a meeting without songs and tales.

From the account I have given, the condition of the Dooraunees must be admitted to be happy, as long as it is not rendered otherwise by causes foreign to the usual habits of their lives. The present confusions, one would think, must disturb those near the cities and great roads, though it may not reach the inhabitants of retired parts of the country; but the evidence of Mr. Durie, who was at Candahar in 1811, and who chiefly saw the neighbourhood of that city, and the highway from it to Caubul, leads to an opposite conclusion. "The people of the Khyles," says Mr. Durie, "both men and women, are very happy, as far as I saw, and in the towns too, they appear to be very happy, only when any kind of contest takes place among the chiefs, it is then that plunder takes

* See his Travels, pages 95, 97, \&e. vol. ii. 
place." In fact, all evidence represents the Dooraunees in the country to be quite secure from the effects of the struggles among the chiefs, and, in the towns, it is probable that the storm produced by those struggles, passed over the heads of the people among whom Mr. Durie lived, and that it was only when a city was taken almost by assault, that they suffered from the revolutions which surrounded them.

The hospitality so conspicuous amongst all the Afghauns, is particularly so with the Dooraunees. Every stranger is welcome wherever he goes. The smallest and poorest camp has its arrangements for the reception of guests, and the greatest nobleman is not exempted from the necessity of providing food and lodging for all who approach his castle.

In most villages, travellers go to the mosque, or Hoojra ; and in common times the first person they meet entertains them. In times of scarcity, they are supplied either by a subscription from the inhabitants, or, much more frequently, by the person whose turn it is to entertain a guest : bread, croot, and clarified butter, are always provided, to which flesh and soup are added, if a sheep has been killed in the village. If an entertainment is going on at any house in the village, the traveller is immediately invited to it, and received with the same attention as if he were a friend and neighbour; and when he retires to rest, he is provided with covering by the person who is allotted to be his host.

This hospitality is not limited to Afghauns, or even to Mahommedans; a Hindoo who came into a Dooraunee village, would meet with the same reception, although his religion would not allow him to eat 
with his entertainers, even if they had no scruples in his company.

Mr. Durie, who passed through the country during a great scarcity, was every where fed and furnished with tobacco, though often it cost his entertainer a great deal of trouble to procure the last article for him, as the crop of it had entirely failed throughout the country. When his feet were sore with walking, they gave him butter to rub them with, and pressed him to stay a day or two. He was sometimes obliged to go round the camp, and receive the contributions of the inhabitants himself; but though he was often known to be a Christian, and at all times must have been a foreigner of a very singular appearance and behaviour, he never met with a refusal or a taunt, and nobody ever showed a disposition to laugh at the oddness of his appearance. Nor did this proceed from dulness or want of observation, for, on the same occasions, the very women used to question him about his travels, and to slow great curiosity about India and the English.

It is strange that the next quality of the Dooraunees I have to mention, should be their love of rapine, but of that defect they are less guilty than most other tribes. Almost all the people I have conversed with, say that none of them plunder the roads, except the Atchikzyes, and some few wretches who take advantage of troubled times to molest travellers; but some accounts of good authority contradict these statements. I think it probable that the people of those parts of the country which are out of sight of the government, are always addicted to robbery, and that during civil war, the 
number of these marauders is greatly increased. It ought also to be observed, that during troubled times the exercise of private revenge, and all other disorders, subsist, with greater chance of impunity, and, therefore, to a greater extent than when the government is settled. In short, their virtues and vices are those of their country, and they appear to have more of the first, and fewer of the last, than any other tribe.

The Dooraunees are distinguished from the other Afghauns by their consciousness of superiority, combined with a sense of national dignity, which gives them more spirit, courage, and elevation of character than the other tribes, at the same time that it renders their behaviour more liberal and humanized. They are extremely attached to their country, and have a sort of reverence for Candahar, which they say contains the tombs of their ancestors : the bodies of their great men are carried thither to be buried, even from Cashmeer and Sind. They travel little, and always long to return home; they never come to India as merchants or adventurers, and are seldom found settled out of their native country. They are a great deal more popular with the other tribes than one would expect among a people so jealous of superiors; the oppressions of their government, and irregularities of their troojs, are often felt and exclaimed against; but all acknowledge their natural superiority, and even the tribes in rebellion treat Douraunees with respect. There is not an inhabitant of the Caubul dominions who would hesitate between the Dooraunees and Ghiljies, or who does not look with dread to the chance of the ascendancy of the latter tribe. 
Even the Ghiljies themselves, though animated by the rancour of unsuccessful rivalry, though inveterate against the government, and though really subject to oppression, acknowledge the merits of the Dooraunees as individuals, and place them above all the Afghauns in hospitality as well as in courage.*

The Atchikzyes differ so much from the other Dooraunees, that I have reserved them for a separate description.

They are by no means a numerous tribe, most accounts fixing their numbers at five thousand families. In my opinion, they do not exceed three thousand.

They are all herdsmen or shepherds; and though they cultivate a little land, it is not on it that they depend for subsistence. Their flocks are kept in the range of Khojeh Amraun, and the high country of

* The following dialogue was taken down almost at the moment when it passed between a Ghiljie and me. He had left his country in the mountains of Solimaun on account of a murder, and had joined a party of banditti who lived in the south of Seestaun, and used to plunder the Dooraunee country. I asked him if they killed Doornunees who fell into their hands? He said, "We never let one escape; and now, if I had an opportunity, I would not give one time to dink water ;" and after a pause, "Are we not enemies ?" I asked him what sort of people the Dooraunees were. "Good people. They dress well; they are hospitable; they are not treacherous; yet we would go among them and serve them, eat their salt, and then set fire to their houses: our hearts burn because we have lost the lingdom, and we wish to see the Dooraunees as poor as ourselves. They say, 'Come, let us be united.' You have taken our kingdom, killed our brothers, and led away our women prisoners, and sliall we unite with you?"

Other Ghiljies, while they praise their manners, said they were full of dissimulation and guile. 
Toba, and their herds of camels in the sandy tract north-east of Shoraubuk. They have also many horses, so that you scarcely ever meet an Atchilkzye on foot.

Their Sirdar has more power than most of the Dooraunee chiefs; but even that power, with his utmost exertions, is not sufficient to check the predatory spirit of his tribe. No traveller can enter their country without being plundered, and they often make nightly expeditions into the lands of their neighbours to steal. Skill in theft, and boldness in robbery, are great qualities among them; and a great deal of the conversation of the young men turns on the exploits of this kind which they have performed or projected. Their robberies, however, are never aggravated by murder.

Their dress is like that of the pastoral Dooraunees; but in winter they make their whole dress, shirts, trousers, caps, and all, of felt.

They live almost entirely on mutton or goat's flesh. They eat little grain, and they have scarce any black cattle among them.

They wear their clothes unchanged for months, their beards unclipped, and their hair long and shaggy. They are very large and strong men.

Their manners are rough and barbarous, but they are not quarrelsome among themselves. Their cudgelling-matches are fierce, when they have them; but they arise in disputes about property, and not in high words or offences to personal pride.

They are not hospitable; they have no mosques; and seldom pray, or trouble themselves about religion : the few Moollahs they have say their Namauz 
at home. All tribes are loud in their complaints against them, and the Dooraunees will hardly acknowledge them for clansmen.

They are, however, excellent soldiers. The talents, courage, and fidelity of their late Sirdar, Goolistaun Khaun, were long the support of Shauh Shujah's cause, in defence of which he lost his life; and his justice and moderation are still gratefully remembered by the inhabitants of Peshawer and Caubul, who have at different times been under his government.

The city of Candahar is large and populous. Heraut and Candahar are the only cities in the Dooraunee country, and, except Furra, probably the only places which even merit the name of a town. The ancient city is sometimes said to have been founded by Lohrasp, a Persian King, who flourished in times of very remote antiquity, and to whom also the founding of Heraut is attributed. It is asserted by others, with far greater probability, to have been built by Secunder Zoolkurnyme ; that is, by Alexander the Great. The traditions of the Persians here agree with the conjectures of European geographers, who fix on this site for one of the cities called Alexandria.

The ancient city stood till the reign of the Ghiljies, when Shauh Hoossein founded a new city, under the name of Husseinabad. Nadir Shauh attempted again to alter the site of the town, and built Nadirabad; at last Ahmed Shauh founded the present city, ${ }^{*}$ to which he gave the name of Ahmed Shauhee, and the title of Ashrefool Belaud, or the noblest of cities; * In 1753 or 1754 .

VOL, II. 
by that name and title it is still mentioned in public papers, and in the language of the court; but the old name of Candahar still prevails among the people, though it has lost its rhyming addition of Daurool Kurrar, or the abode of quiet. Ahmed Shauh himself marked out the limits of the present city, and laid down the regular plan which is still so remarkable in its execution : he surrounded it with a wall, and proposed to have added a ditch; but the Dooraunees are said to have objected to his fortifications, and to have declared that their ditch was the Chemen of Bistaun (a meadow near Bistaun, in the most western part of Persian Khorassaun). Candahar was the capital of the Dooraunee empire in Ahmed Shauh's time, but Timur changed the seat of government to Caubul.

I am utterly at a loss how to fix the extent of Candahar, or the number of inhabitants it contains. I have always heard that Candahar was larger than Heraut; but Captain Christie, who resided for a month at Heraut, considers the numbers of its inhabitants to be one hundred thousand, a number which I cannot reconcile with the comparison I have heard between Candahar and Peshawer.*

The form of Candahar is an oblong square, and as it was built at once on a fixed plan, it lias the

* I feel much greater hesitation in every thing I have to say of towns which I have not seen than in my accounts of the country; the inhabitants of the country are less given to falsehood, and a comparison with neighbouring regions renders it easier to detect them when they are disposed to exaggerate; nor is it so easy to invent n consistent account of the produce and character of a country as to mag: nify the size and heighten the magnificence of a town. [Mr. Conolly 
advantage of great regularity. Four long and broad bazars meet in the middle of the town, and at the place of their junction there is a circular space of about forty or fifty yards in diameter, covered with a dome, into which all the four streets lead.

This place is called the Chaursoo; it is surrounded with shops, and may be considered as the public market-place; it is there that proclamations are made, and that the bodies of criminals are exposed to the view of the populace. Part of the adjoining bazar is also covered in, as is usual in Persia and in the west of the Afghaun dominions.

The four bazars are each about fifty yards broad; the sides consist of shops of the same size and plan, in front of which runs an uniform veranda for the whole length of the street. The shops are only one story high, and the lofty houses of the town are seen over them. There are gates issuing into the country at the end of all the bazars, except the northern one, where stands the King's palace, facing the Chaursoo.

Its external appearance is clescribed as not remarkable, but it contains several courts, many buildings, and a private garden. All the bazars, except that leading to the palace, were at one time planted with trees; and a narrow canal is said to have run down the middle of each; but many of the trees have

estimates the population of Heraut at 45,000. He did not enter Candahar, but heard in the neighbourhood that it was one-third larger than Heraut. Mohun Lal, who estimates Heraut at 4000 houses, says of Candahar, that the majority of the inhabitants are Afghauns, and that there are 2000 families of Persians. The whole number must, therefore, be greater than in Hermut.-1838.] 
withered, and if the canals ever existed, they are now no longer visible. The city is, however, ver'y well watered by two large canals drawn from the Urghundaub, which are crossed in different places by little bridges. From these canals, small water-courses run to almost every street in the town, which are in some streets open, and in some under ground. All the other streets run from the four great bazars. Though narrow, they are all straight, and almost all cross each other at right angles.

The town is divided into many Mohullas, or quarters, each of which belongs to one of the numerous tribes and nations which form the inhabitants of the city. Almost all the great Dooraunees have houses in Candahar, and some of them are said to be large and elegant.

There are many caravanserais and mosques; but of the latter one only, near the palace, is said to be liandsome. The tomb of Ahmed Shauh also stands near the palace; it is not a large building, but has a handsome cupola, and is elegantly painted, gilt, and otherwise ornamented within. It is held in high veneration by the Doornunees, and is an asylum against all enemies, even the King not venturing to touch a man who has taken refuge there. When any of the great lords are discontented, it is common for them to give out that they intend to quit the world, and to spend their lives in prayer at the tomb of Ahmed Shauh; and certainly, if ever an Asiatic king deserved the gratitude of his country, it was Ahmed Shauh.

On the whole, Candahar, though it is superior to most of the cities in Asia in its plan, is by no means 
magnificent. It is built for the most part of brick, often with no other cement than mud. The Hindoos, as usual, have the best houses of the common people, and they adhere to their custom of building them very high. The streets of Candahar are very crowded from noon till evening, and.all the various trades that have been described at Peshawer, are also carried on there, except that of water-sellers, which is here unnecessary, as there are reservoirs every where, furnished with leathern buckets, fitted to handles of wood or horn, for people to draw water with. Ballad-singers and story-tellers are also numerous in the bazars, and all articles from the west are in much greater plenty and perfection than at Peshawer.

Contrary to what is the case with other cities in Afghaunistaun, the greater part of the inhabitants of Candahar are Afghauns, and of these by far the greater number are Dooraunees. But their condition here bears no resemblance to that of their brethren in the country. The peculiar institutions of the Afghaun tribes are superseded by the existence of a strong government, regular courts of law, and an efficient police. The rustic customs of the Afghauns are also in a great measure laid aside; and, in exteriors, the inhabitants of Candahar a good deal resemble the Persians; the resemblance is, however, confined to the exterior, for their characters are still marked with all the peculiarities of their nation. The other inhabitants are Taujiks, Eimauks, Hindoos, Persians, Seestaunees, and Beloches, with a few Uzbelss, Arabs, Armenians, and Jews.

There are many gardens and orchards round Candahar, and many places of worship, where the inha- 
bitants make parties more for pleasure than devotion. 'Their way of life is that of the other inhabitants of towns, which has already been explained.

Shoraubuk, the country inhabited by the tribe of Baraich, is situated between the Dooraunee lands on the north, and the mountains belonging to the Brahoee Beloches on the south; the range of Khojeh Amraun (there called Roghaunee and Speen Taizeh), separates it from Pisheen on the east, and the great sandy desart extends round all its western frontier. The south-western part is inluabited by Beloches, to whom Noshky, forty or fifty miles from Shoraubuk, belongs.

It is cut by the river Lora, near which are some trees and bushes, but the rest is a bare plain of hard clay, quite flat, and very arid.* The whole country is about sixty miles square. The number of inhabitants is two thousand five hundred, or three thousand families. They are divided into four clans, under four Khauns, who have great power. The King receives four hundred horse from the tribe, and takes no farther concern in its affairs.

They have many camels that feed on their numerous and extensive wastes, are used to ride on, and are almost the only animal used to draw the plough.

They live in Cooddools, or large, arched huts of wattled tamarisk branches, covered with hurdles of basket work, and plastered with clay. The rich, however, have often houses; and all spend the spring in tents on the borders of the desart, which is their

* [The irrigation from the Lora appears from Mr. Conolly to be much more extensive than is here supposed, so that Shoraubuk is in reality a well-watered and productive tract.-1 838.] 
greatest pleasure. Their dress, food, and manners are like those of the rudest Dooraunees, but they often eat camels' flesh, and even horse flesh. They are a very simple and inoffensive people.

Adjoining to the Baraiches on the east, is Pisheen, the country of the Tereens. 'That tribe is divided into two great branches; the Tor (or black) Tereens, and the Speen (or white) Tereens. It is the Tor Tereens who inhabit Pisheen.

Pisheen is divided from the Dooraunee country on the north by hills; other hills cut it off from the Caukers on the east; and on the south, it is divided from Shawl by the range of Tukkatoo, which stretches east from the table-land of Kelaut. Its greatest length is about eighty miles from north-east to southeast, its greatest breadth about forty miles.

Pisheen is much higher than Shoraubuk. Its surface is much more uneven, and it is much better cultivated. It also is divided by the. Lora. Bullocks are a great deal more used to plough than camels, though these are numerous.*

The principal employment of the people is agriculture, but a great proportion of them is occupied in trade between Candahar and Upper Sind, and in the business of carriers.

Their manners have a great resemblance to those of the Dooraunees, witl whom they are closely connected both by descent and friendship.

The Khaun is on the same footing as a Dooraunee Sirdar; but the King never interferes with him,

* [Pisheen was visited by Mr. Conolly, and is of less extent and less fertility than is here supposed. It is only 60 miles long and 30 broad.-1838.] 
except to call for the service of his contingent, or his personal attendance at court.

The number of inhabitants of Pisheen may be guessed at eight or ten thousand families.

A great part of the population consists of Syuds, whose habits and employments are the same as those of the Tereens. In common with the whole of the prophet's family, they have the reputation, and, in consequence, perhaps the merit, of courage and good morals. The Tor Tereens, the Syuds, and some Cauker Humsauyehs, are the only people in Pisheen. The Speen Tereens possess the long valley of Zawura, and the open plains of Tull and Chooteeallee, countries which extend from near Pisheen to the range of Solimaun, within a march or two of Upper Sind. They are separated from the Tor Tereens by a portion of the Cauker country, but they are under the authority of the common Khaun, who makes an annual journey to assemble their share of the Tereen contingent, or to receive the fine which they generally pay in preference to personal service. Their manners are those of the Tor Tereens, greatly mixed with those of the Caukers, in the midst of whom they reside. 


\section{CHAPTER V.}

THE GHILJES, CITIES OF GIUUNES AND CAUBUL, WURDUKS, AND CAUIKERS.

Tux lower part of the valley of the Turnuk has been described as belonging to the Dooraupees; a ruined bridge to the east of Toot, which is called Poolee Sungee (or the stone bridge), lies between their territory and that of the Ghiljies, and the boundary line will not be very incorrect, if it be drawn through that point, north and south, from the Paropamisan mountains, to the bills on the right of the Urghessaun. The north-western boundary may be said to be formed by the Paropamisan mountains, though some hilly tracts dependant on that range, are included in the Ghiljie lands; and, on the other hand, a narrow tract of sixty miles long, is cut out of them between Caubul and Ghuznee, and belongs to the Wurduks. On the north, the river of Punjsheer divides it for some distance from the Cohistaun of Caubul; but after that river has joined the river of Caubul, the Ghiljie country crosses it, and occupies both banks as far east as the heights above Jellallabad, where it meets the country of the Berdooraunees. The rest of its eastern frontier is formed by the mountains of Solimaun. Its southern limits are ill defined; on the south-east it has 
Wauneh, and some other barren tracts about the Gomul: on the south-west it is divided by hills from Urghessaun, and in the intermediate portion of the southern frontier, the pasture grounds of the Ghiljies are sometimes intermixed with those of the Caukers, and sometimes separated from them by wastes of considerable extent; but as they are desarts for which no one would contend, there is little reason to regret the impossibility of assigning with precision the shares of the two tribes.

The country comprehended within these limits is various. The valley of the Turnuk, enclosed between the Paropamisan mountains on its northwest, and the hills which run from Mookkoor to Kellaee Abdooreheem on its south-east, is a plain diversified by swells and hollows; its length is upwards of sixty miles, and its breadth under twenty. It is high and ill watered, and the last defect increases with its height, so that near Mooklsoor, it is scarcely fitted either for agriculture or pasture; of the remainder, the central part on the river is partially cultivated; beyond that, on each side is infertile; it is covered with bushes alone, has few caureezes, and fewer villages, and is only used as pasture land in summer by tribes who withdraw to other climates when the cold sets in. The villages which have flourished in this district, suffered greatly in the Ghiljie rebellion, and are now in a state of decay; Kelaut, the largest of them, which is considered as a town, and is the residence of the chief of the clan of Tokhee, contains only two or three hundred houses. The northern part under the lills affords more grass, and is full of camps in the season. 
The tract dependant on the Paropamisan mountains, is inhabited by predatory Tokhees, and, from the character of the inhabitants, one would expect it to be rough and poor; it seems, accordingly, to be composed of hills destitute of water, and perhaps of soil, with valleys too narrow to admit of much cultivation. The inhabitants live in tents, and are supported by their flocks.

To the south of the range of hills which runs from Mookkoor to Kellaee Abdooreheem, is a tract of country, of which the part to the north of the $32 \mathrm{nd}$ parallel of latitude, is crossed by hills enclosing plains, which in many places are watered by caureezes, and in others support numerous hordes of shepherds. Among the best cultivated spots, are Hullataugh, Ghoondaun, and Puttunye; but Kellaee Abdooreheem Khaun alone deserves particular notice, as being the capital of the clan of Hotulsee, and the chief fort of the descendants of the Ghiljie Kings. It is, however, a place of no strength, and is surrounded by black tents, with a few houses. It stands in a small district called Ghwurra Murgha; which is divided by hills from the valley of the Urghessaun, into which the stream that passes Kellaee Abdooreheem, nevertheless makes its way.

The Ghiljie country to the south of latitude $32^{\circ}$, consists chiefly of sandy plains, and high stony tracts, or barren hills : that in the south-east, near the junction of the Coondoor, and the Gomul, is of the last description ; but there, in the midst of lofty and inaccessible mountains, is the little valley of Mummye, where Abdooreheem Khaun (the head of the Ghiljies, and their King during the rebellion,) has found 
a secure retreat from the real or imagined resentment of the Dooraunee government. It is inhabited by shepherds in tents, but Abdooreheem has founded a fort, and is making a garden, and, perhaps, introducing agriculture.

From the meridian of Mooklkoor to the hills on the right bank of the Gomul, and from Ghwashta to Ghuznee, is the bason of the Aubistaudeh, an open country of various fertility, and in different states of improvement: the districts of Mookkoor, Karra-baugh, and Naunee, to the west of Ghuznee, are naturally infertile, and thinly inhabited: the testimony of the natives assigns one hundred and twenty forts or cistles to Mookkoor, and one hundred to Karra-baugh; and, as almost every village in the Ghiljie country is a fort, and none in this part contains more than five or six families, the account is probably correct.

The country to the south of these districts, and that called Kuttawauz, which extends from Ghwashta to within twenty miles of Ghuznee, are open, partially cultivated, and watered by caureezes, and by some brooks that run into the Aubistaudeh. The borders of that lake are covered with low tamarisks; and a plane tree, a poplar, or a willow may be found here and there near a caureez; but there is no natural wood, and the country is naked and uniform.

Divided from this tract by the Gomul, and the hills on its right bank, are the woody mountains and narrow plains of the Kharotees; but I shall leave them for a fuller description hereafter.

Immediately to the south of Ghuznee is the rich district of Shilgur, which, with the country round the city, is highly cultivated, and abounds in villages 
and gardens. Though it has little natural wood, many plane trees and poplars are planted, for the salre of the timber ; the want of which article is, however, felt in all this country, and is remedied in building by the use of the arched roof.

Ghuznee itself, which eight centuries ago was the capital of an empire reaching from the Tigris to the Ganges, and from the Jaxartes to the Persian Gulf, is now reduced to a town containing about fifteen hundred houses, besides suburbs without the walls. The town stands on a height, at the foot of which flows a pretty large stream. It is surrounded by stone walls, and contains three bazars of no great breadth, with high houses on each side, and a covered Chaursoo, besides several dark and narrow streets. Some few remains of the ancient grandeur of the city are still to be seen in its neighbourbood, particularly two lofty minarets, which stand. at some distance from each other, and are of different heights, the least upwards of one hundred feet high. The tomb of the great Sultan Mahmood is also standing, about three miles from the city. It is a spacious, but not a magnificent building, covered with a cupola. The doors, which are very large, are of sandal wood, and are said to have been brought by the Sultan as a trophy from the famous temple of Somnaut in Guzerat, which he sacked in his last expedition to India. The tomb-stone is of white marble, on which are sculptured Arabic verses from the Koraun, and at its head lies the plain but weighty mace, which is said to have been wielded by the monarch himself. It is of wood, with a head of metal so heavy that few men can use it. There are also some thrones, or chairs, inlaid 
with mother-of-pearl, in the tomb, which are said to have belonged to Mahmood. The tomb-stone is under a canopy, and some Moollahs are still maintained, who incessantly read the Koraun aloud over the trate.

There are some other ruins of less note, among which are the tombs of Behlole Dauna (or Behlole the wise) and that of Hukeem Sunauee, a poet still greatly esteemed in Persia; but nothing remains to show the magnificence of the palaces of the Gaznavide kings, (which at one time were the residence of Ferlaume, the Homer of Asia), or of the mosques, bathis, and carananserais which once adorned the capitat of the East. Of all the antiquities of Ghuznee, the rnost useful is an embankment across a stream, which was built by Malımood, and which, though damaged by the fury of the Ghoree kings at the capture of Ghuznee, still supplies water to the fields and frardens round the town. The immediate environs of the city are inhabited by Taujiks and Hazaurehs; and the valley which is contiguous to them on the north, belongs to the Wurduls; but the country between the hills which bound that valley on the east and the mountains of Solimaun, is inhabited by the Chiljies. It is crossed by several high ranges of hills: but anong them are found the rich valley of Gurdaiz (which contains a town of many hundred houses), the plain of Khurwaur, and the still more extensive plains of Zoormool and Logur. These districts are surrounded with hills, but are fertile, well watered, and well cultivated : the three first belong to the Ghiljies, though a large portion of the inhabitants are Taujiks: Logur is divided between the 
Ghiljies and the Taujik tribe of Burrukee, but Altamoor on the east of Logur, and the high, cold barren valley of Speiga, which runs up from Logur towards the ridge of Solimaun, afford pasture to the flocks of the Ghiljie clan of Ahmedzye. The highly cultivated lands for twenty miles round Caubul are occupied both by Ghiljies and Taujiks, but the numbers and manners of the Taujiks prevail, and the whole is formed into a separate government distinct from the Ghiljies. I shall, however, notice it in this place, as it is situated in the midst of the Ghiljie lands.

The city of Caubul is enclosed on three sides by a semicircle of low hills, along the top of which runs a weak wall. There is an opening towards the east, which is enclosed by a rampart, and here the principal road enters through a gate, after passing a bridge over the river. The Balla Hissaur, which stands on the part of the hill north of this entrance, is a kind of citadel, and contains the King's palace, in which are several halls distinguished with the royal ornament of a gilded cupola. There is an upper citadel used as a state prison for princes of the blood.

In the centre of the city is an open square, whence issue four bazars two stories high, arched over like those already mentioned. Most of the buildings of Caubul are of wood, a material recommended by its power of resisting the frequent earthquakes with which the place is visited.

Caubul, though not an extensive city, is compact and handsome. The descriptions I have given of other towns will suffice for it, if it be recollected that it is the seat of the court and the grand emporium 
of trade. The abundance and arrangement of its bazars have been already a theme of praise to an European traveller.* The city is divided by the stream which bears its name, and is surrounded, particularly on the north and west, by numerous gardens and groves of fruit trees. The most pleasing spot about it is the tomb of the Emperor Bauber, which is situated at the top of a hill over the city, surrounded by beds of anemonies and other flowers, and commanding a noble prospect. The town itself, and the neighbouring meadows, fields, and orchards, watered by streams, interspersed with villages, and encompassed by mountains, all contribute to the grandeur and variety of the landscape.

The charms of the climate and scenery of Caubul have been celebrated by many Persian and Indian writers. The beauty and abundance of its flowers are proverbial, and its fruits are transported to the remotest parts of India. $\dagger$

The four 'Tuppehs of' districts immediately dependent on Caubul, (Bootkauk, Logur, Pughmaun, and Cohdaumaun), are all fertile, well watered, and cultivated with great industry and skill. Pughmaun, which lies to the west towards the Hazaureh country, is least fertile; and Logur to the south, which contains many low hills, has most pasture land; but Cohdaumaun, which lies north of the city, is the finest part of these districts, and perhaps of the lkingdom. It lies, as its name implies, on the skirts of the mountains, whence it derives an abundant supply of water;

* Mr. Foster.

$\uparrow$ [See also Sir A. Burnes's animuted and interesting description of Caubul and its neighboumhood,-1838.] 
and so numerous are the fruit trees produced in it, that the valley of Estaulef alone is reckoned to contain six thousand orchards: the city and its immediate neighbourhood is inhabited by a peculiar class of Taujiks called Caubulees, who are remarkable for their activity and ingenuity, and who have more than once made themselves of considerable importance in the revolutions of the state. The number of the inhabitants of the town may be about eight thousand.

The valley of the Caubul river, till it reaches Jellallabad, and meets the country already described as inhabited by the Berdooraunees, belongs exclusively to the Ghiljies. It would be tedious to describe all the little valleys which run up to Hindoo Coosh and to Suffaid Con, or to specify the cold and hot plains (above and beneath the mountains) which are cultivated by the Ghiljies, and the rugged summits which are fed on by their flocks; but this very enumeration will suggest the diversity of this abrupt and broken region.

The country of the Ghiljies forms a parallelogram, of which the length is about a hundred and eighty, and the breadth about eighty-five miles. The animals of the Ghiljie country are the same as those of the Dooraunee country.

The climate is everywhere cold, but least so in the lower part of the valley of the Turnuk: every where else, the winter is severer than that of England, and the summer not much hotter.

The Ghiljies were in former times by far the most celebrated of the Afghauns. In the beginning of the

VOL. II. 
last century this tribe alone conquered all Persia, and routed the armies of the Ottoman Porte:* after a hard struggle, the third Ghiljie King of Persia was expelled by Nadir Shauh; but some of the tribe remained independent in that country till very lately, if indeed they are even now sublued. They inhabited Khubeess and Nermaunsheer in the province of Kermaun. Some others still remain in Persia, mixed with the body of the people. The most famous that lias appeared since the downfall of their own monarchy, was Azaud Kham Solimaun Khail, who set up for King of Persia, and is well known as the most formidable of Kereem Khaun's competitors. It is said, both by the Persians and Afghauns, that their long struggle for the throne ended in a faitluful friendship, and that Azaud lived for many years in safety and honour at the court of his successful rival. The fact is consistent with Kereem Khaun's character; and in a country where there is such a dearth of good faith and generosity, one would fain hope that it is authentic. Azaud Kbaun's son now resides in Lughman. There are also many Ghiljies in the Uzbek service, who bear a ligh reputation; they probably were sent to Bolkhara by Nadir, or emigrated in con-

* See Hanway's Trnvels, and Jones's Histoire de Nadir Clrah, the first of which contains a very full and interesting account of all the successes and disasters of the Ghiljies in Persia. There is also a particular history of the Ghiljie conquest, drawn up from the notes of a Père Krusinki, who was in Isphahaun at the time; but the easy faith of the good Jesuit, and the lively imagination of his French editor, have produced an historical romance, which, though not destitute of information, requires as much knowledge to distinguish between the truth and the falsehood, as would have sufficed for the production of a correct history. 
sequence of the depression of their tribe. The manner in which they lost their kingdom, and the bold rebellion by which they lately attempted to regain-it, will be found in the historical part of this account. Their pretensions to the sovereignty are now laid aside, and the moderation of the Dooraunee Government has in some measure disarmed the resentment which they felt for their reduction; but they still fondly recal the ancient grandeur of their tribe; and the royalty of the Shauh Allum Khail, and the hereditary stations of their Khauns, are yet acknowledged and respected by them all.

The character of the tribe is as various as the country it inhabits: a summary view of the whole, together with some details respecting the clans which differ most from the western tribes already described, will probably be sufficient to communicate all that is interesting of the information which I possess. An examination of the clans into which the Ghiljies are divided, and a statement of the part of the country which each inhabits, are, however, necessary to render this intelligible.

The Ghiljies are divided into the families of Toraun and Boorhaun, which branch into eight clans. Toraun is the eldest family, and consists of the clans of Hotukee and Tokhee; from the first of which were sprung the kings, and from the second the vizeers, of the Ghiljie dynasty.

To Boorhaun belong the clans of Solimaun Khail, Ali Khail, Suhauk, Under, and Turrukee. It is uncertain, even with the Ghiljies, to which branch .we ought to assign the remaining clan of Kharotee. To these clans may be added that of Sheerpau, though it 
is not a clan, but an association formed out of the other eight.

The Hotukees were formerly a numerous clan, but they are now reduced to 5000 or 6000 families. They are chiefly employed in agriculture and commerce, yet they generally live a great deal in tents, and feed many flocks: they ar'e mixed with the Tolshees in the tract south of the range of Mookkoor, in which the castle of Abdooreheem, their chief, is situated.

The Tokhees are reckoned 12,000 families; their principal place is Kelauti Ghiljie. Besides the country which they share with the Hotukees, they have the valley of the Turnuk to themselves. They have also the hilly country on the edge of the Paropamisan mountains.

The Turrukees have Mookkoor and the country around it, extending to the south as far as the southern border of the Ghiljies. They are called 12,000 families; many of them are pastoral, and of those some move in winter into the Dooraunee country, while other's wander as far as Damaun.

The Unders are also said to be 12,000 families. They cultivate the rich district of Shilgur and some of the adjoining country.

The Kharotees inhabit the hills between the Gomul and the range of Solimaun. They are about 6000 families.

The Alikhails are reckoned 8000 families; a number far too great, since they have little land except the plain of Zoormool, and even there are only half the population.

The Solimaun Khail is much more numerous than 
any other Ghiljie clan: its numbers are said to amount to 30,000 or 35,000 families. It is divided into four distinct Ooloosses, but may be taken in two parts, the southern and northern, with reference both to geographical and to political situation.

The Kyser Khail and Summulzye, or Ismaelzye, form the first of these divisions : they live to the south and east of Ghuznee, and it is they who share Zoormool with the Alikhail. They may be about 5000 families each; part of them move in winter to Wauneh. They are very independent both of the King and their own chiefs, as are their neighbours the Alikhail,*

The northern division consists of the Stauneezyes or Sooltaunzyes, and the Alimedzyes : the former, which are most numerous, inhabit the country north of the Wurduks, and are agricultural.

The Almedzyes are pastoral, and live in the east of Logur, in Altamoor and Speiga, but drive their flocks as far east as the hills over Jellallabad.

They are obedient to the King, and did not even take part in the Ghiljie rebellion.

The Suhauks are 5000 or 6000 families; one-third lives in Khurwar, and probably bears the same character with the southern Solimaun Khails: the rest are in Pughmaun, west of Caubul, and resemble the other Ghiljies in that neighbourhood.

The Sheerpaws (6000 families) are mixed with the Taujiks in the Coldamun, and along the northern bank of the Caubul river, as far as the eastern border

* Though I have mentioned the chief residence of each clan of the southern Solimaun Khail, it must be observed that they are a good deal mixed. 
of the Ghiljies. They are said to be the superfluous population of the other clans which emigrated from Candahar long before the rest of the tribe.

The Ghiljies of the west, as far nearly as to the meridian of Ghuznee, bear a close resemblance to the Dooraunees. This resemblance diminishes as we go eastward. The Hotnkees and Tolshees, in dress, manners, and custons, and in every thing which is not connected with their mode of government, exactly resemble the neighbouring Dooraunees. The Turrukees, though more similar to the Dooraunees than to any other tribe, mix something of the manners of the eastern Ghiljies, and this most in the southern part of the Turrukee country. The Unders resemble the eastern clans in every thing but their government.

The eastern Ghiljies differ widely from the Dooraunees, and will require a separate discussion. They even differ among themselves, those around Caubul bearing but a slight resemblance to those in the south, but there are some points in which the whole tribe differs from the Dooraunees, and which I shall state before I proceed to the partial diversities I have been alluding to.

The internal government of the Ghiljies is entirely different from that of the Dooraunees. The chiefs of the former have now lost the authority which they possessed under their own royal government. There is great reason to doubt whether that authority ever was so extensive as that which has been introduced among the Dooraunees on the Persian model. It is more probable that the power even of the King of the Ghiljies was small in his own country, and 
that the tumultuary consent of the people to support his measures abroad, was dictated more by a sense of the interest and glory of the tribe than by any deference to the King's commands. Some appearances, however, warrant a supposition that his power was sufficient to check murders and other great disorders. Whatever the power of the King may have been formerly, it is now at an end, and that of the aristocracy has fallen with it; and though it has left sentiments of respect in the minds of the common people, yet that respect is so entirely unmixed with fear, that it has no effect whatever in controlling their actions. No Khaun of a tribe or Mullik of a village ever interferes as a magistrate to settle a dispute, or at least a serious one; they keep their own families and their immediate dependents in order, but leave the rest of the people to accommodate their differences as they can. This may be presumed not to have been always the case, because it has not yet generally produced the compulsory trial by a Jeerga (or assembly of elders), which subsists among the Berdooraunees, so long habituated to strife; neither has it exasperated the tempers nor embittered the enmities of the Ghiljies, as it has with the people just mentioned.

The degree in which this want of government is felt is not the same throughout the tribe: among the people round Ghuznee and Caubul, the power of the King's governor supplies the place of internal regulation. In many tribes more distant from cities, the neighbourhood of one of the King's Cauzees, or the deputy of that magistrate, induces one party to have recourse to the Shirra, or Mahommedan law, 
an appeal which no Mussulman can decline. With the Hotukees, the Tokhees, and generally with the Ghiljies on the great roads, the authority which the chiefs derive from the Dooraunee government, and perhaps the respect still paid to their former rank, enables them to prevent general commotions, though they cannot suppress quarrels between individuals; but among the southern Solimaun Khail these disor. ders rise to feuds between subdivisions of a clan, and even to contests of such extent as to deserve the name of civil wars : yet even in the most unsettled tribes the decision of an assembly of Moollahs is sufficient to decide disputes about property, and one great source of quarrels is thus removed.

'Among the eastern Ghiljies, and especially among the Solimaun Khails, the power of the chief is not considerable enough to form a tie to keep the clan together, and they are broken into little societies (like the Eusofzyes), which are quite independent in all internal transactions. Their connexion with the King, however, makes a difference between their situation and that of the Eusofzyes, and, in consequence, each chief has power over the whole of his clan in all matters connected with the furnishing of troops to the King, or the payment of the royal revenue. This limited authority preserves some connexion between the different subclivisions under one Khaun, and often delays the breaking up of a clan after it has attained the number which naturally requires separate chiefs. It is obvious how great a difference the circumstances I have been stating must make in the lives of the Ghiljies and Dooraunees; but this will be more evident from a description of a village of the southern Solimaun Khail. 
The Kalunder Khail live in Kuttawauz, about thirty miles to the south of Ghuznee. They are almost all husbandmen, and scarce keep any cattle, those used in agriculture being generally hired from pastoral hordes, who pass the spring and summer in Kuttawauz. Their country is not rich, it only produces grain where there are caureezes, and yields but one harvest in the year: it will not bear wheat two years on the same ground, and even with the proper succession of crops it requires manure. 'The climate is very cold. Their village contains about a hundred families: some Humsauyehs assist in the cultivation of their fields, but reside in a village at some distance. Their wood and iron work is performed by travelling artizans.

Their land is their own property; or if they have the fiction of a feodal tenure from the King, it does not affect their rights, either in reality or in form: every man disposes of his land as he pleases, and at his death it is divided among his children. Small as it is, their village is an independent republic. It is indeed included in the Shummulzye division of the clan of Solimaun Khail, and the Khaun of that division collects the King's dues; but he interferes in nothing else; and were it not for his employment under the royal government, all connection between him and his division would long since have ceased. The village is divided into two Mohullas, or quarters, under two chiefs, Moraud aud Fyztullub. Moraud is the head of the whole village, and is called Mullik. Their authority is entirely confined to external affairs, and they never interfere in the disputes of the people, unless when one of them is armed with 
the temporary powers of a Chelwashtee. Quarrels are privately made up or allowed to continue till they become troublesome to the community, when one or both of the disputants are expelled the village : civil suits are settled by Moollalss. Public affairs are managed by the Mullik in consultation with Fyztullub; but in any transaction which might lead to war, or otherwise seriously affect the village, the Mullik assembles the elders and takes their advice : no questions of course are put to the vote, but the Mullik gathers the sense of the assembly, observes whether their views agree with his, and judges how far he may rely on their support, if he finds that their opinion is different from his own. When a war is resolved on, Chelwashtees are immediately appointed, and the command of them is invariably conferred on Fyztullub, who in consequence is called the Meer, a title which he retains at all times, as Moraud does that of Mullik. $\mathrm{He}$ is formally invested with his office by the Mullik, who binds a turban round his head in the presence of the whole village, of which he immediately assumes the control. He calls out the fighting men, posts sentinels, and makes all military arrangements; while he prevents internal disorder by imposing fines on all who break the peace. The Mullik loses his importance from the time the Chelwashtee is appointed: he still retains his superior rank and honour, but he interferes in nothing, and would be as liable to punishment as any other individual, if he engaged in any quarrel or disturbance. The custom of appointing Chelwashtees prevails all over Kuttawauz: it seems indeed to be rendered equally necessary in all parts of that country, by the 
feuds which subsist between neighbouring villages. I am, however, inclined to think that this state of things has not always existed, because the custom of fortifying the villages seems only coming in, and most. of those in Kuttawauz are still open.

Notwithstanding their domestic quarrels and feuds with other tribes, they are by no means a violent or irritable people. They generally live in tolerable harmony, and have their meetings and amusements like the Dooraunees, undisturbed by the constant alarm, and almost as constant frays, of the Eusofzyes. They are very hospitable, and have a regular officer whose duty it is to receive and provide for guests at the expense of the village. Instead of the Persian cubba of the Dooraunees, or the original* cameess of the Afghauns, (which is here only worn by old men,) the generality wear the Indian dress of white cotton, which has been clescribed as worn by the inhabitants of Damaun, to whom these Ghiljies bear some resemblance in their appearance and manners. 'Their dress is also distinguished from that of the tribes farther west by the use of white turbans. They also wear a cap like that of the Dooraunees, but much higher.

Their arms are the same as those of the Dooraunees, with the addition of a shield of buffalo's hide, or, when it can be procured, of the skin of a rhinoceros.

Most men have a stripe shaved in the middle of their heads, like the Dooraunees ; but those who set up for professed champions let all their hair grow: it is customary with each of those, when he is just

* The large loose shirt, 
about to close with the enemy, to drop his cap, and rather to give up his life than retreat beyond the spot where it has fallen.

I have mentioned that the Kalunder Khail are almost all husbandmen : there are, however, five or six families of shepherds among them, who, like the other numerous shepherds of Kuttawauz, leave their frozen plains during part of the year, for the low and sheltered country among the mountains on the banks of the Gomul. Wauneh, in particular, is a favourite retreat, and the small number of its owners, the Dumtaunees, alike prevents their resisting this invasion of their property, and their suffering by such an addition to their population. It is generally thought that men often quit the life of a shepherd for that of a husbandman, but never return from an agricultural to a pastoral life. The few shepherds of the Kalunder Khail, however, furmish an example to the contrary. The uncle of a man from whom I had the story, was possessed of land in Kuttawauz, but he married into a pastoral family, and being struck with the pleasures of a wandering life, he laid out a sum of money he had gained by some madder which he had cultivated, on the purchase of sheep, and joined the moving horde with which he was connected. The pleasures which seduced him must seem great even to the husbandmen, for those of the Kalunder Khail, at least, annually betake themselves to the imitation of a pastoral life. Every summer they pitch their tents at some distance from the fort, which is so entirely abandoned that the gates are locked: they remain in tents during the whole of the summer, moving occasionally within a moderate space round their fort. 
"The enjoyments of this season are great," (says one of my informants,) "but its pleasures are equalled, if not surpassed, by the idleness and repose of winter." Besides the shepherds who only move to the Gomul, there are others who prolong their march to Damaun. These are joined by merchants from the fixed inhabitants, and the whole number is considerable. Such are the manuers of the inliabitants of Kuttawauz, and probably of the Alizyes of Zoormool, the Suhauks of Khurwaur, and of all the southern Solimaun Khail: but the interposition of the village in checking disturbances is more marked in many divisions, and in some they even compel the parties to submit to a Jeerga, or to quit the village. In some clans, too, the form of government is more decidedly republican, and the sentiments of every individual must be taken before any measure of importance is decided on.

This is the case among the Ahmedzyes who possess the east of Logur, and all the southern part of the valley of the Caubul river, as far as Jellallabad. Yet as they are in perfect obedience to the King, the Khaun of the whole division, who is the representative of the sovereign, has much more influence than among the southern Solimaun Khail; and the whole division, though it consists of 12,000 families, looks up to him as its head in all cases.

The Ghiljies in the four Tuppehs of Caubul are a quiet, orderly, industrious set of people, entirely obedient to the King, and subject to the authority of their own Khauns. In dress, and in some respects in manners, they resemble the citizens of Caubul.

The King derives a moderate revenue from the whole of the Ghiljies; but it has almost all been 
allotted to different persons, so that little now comes into the royal treasury. Part is granted to the Khauns of the Ghiljies themselves ; part to the Dooraunee Sirdar who commands their contingent of troops; and a considerable portion was assigned to Abdooreheem Khaun, and has not been resumed since his rebellion.

In their character the Ghiljies are confessedly the second tribe in the Caubul dominions. They are more turbulent and less civilized than the Dooraunees, but they are a brave and respectable people. In their persons they are probably the largest, handsomest, and fairest of the Afghauns.

The dissimilarity of their country to that of the tribe they belong to gives the Kharotees the same claim to separate mention which has been allowed to the Atchikzyes among the Dooraunees. Their manners indeed do not differ so much from those of their brethren, but their interests are more distinct, and they really form a community only connected with the Ghiljies in name.

The Kharotees inhabit the country situated to the east of Kuttawauz, among the branches of the range of Solimaun. They have the principal ridge of that chain on the east, and a branch which it sends out separates them from Gurdaiz on the north; the Gromul is their boundary on the west, as it would be on the south, but for the interposition of the little territory of Wauneh. The Kharotee country encloses the little district of Oorghoon, belonging to the Poormoollees or Foormoollees, an independent tribe of Taujiks.

The Kharotees possess a few narrow plains and valleys, divided by high and inaccessible mountains. 
They count four towns, or rather villages, since Sirufza, the largest of them, only contains 500 houses. They amount to 5000 or 6000 families, most of whom follow agriculture.

Their country, though richer than Kuttawauz, produces but one harvest in the year, and is buried in snow for three months every winter. They have bullocks for the plough, but the nature of their country makes them prefer goats to sheep for the remaining part of their stock; yet they have many camels in the plains.

In most particulars they resemble the southern Solimaun Khail ; but the whole clan is united under the command of the hereditary Khaun, who has respect and weight, though little or no power. The Mulliks of villages are equally weak; but as men are obliged to submit their quarrels to a Jeerga, their want of power is not so much felt. One fact is alleged of them on good authority, which is so much at variance with the practice of the Afghauns that I am almost inclined to doubt its accuracy. It is that they pay more attention to wealth and popularity than to birth in the election of a Mullik. I can discover nothing in the situation of the Kharo. tees to account for this unusual neglect of hereditary superiority.

They are often at war with their rude neighbours, the Vizeerees and Jadrauns, and also with the Foormoollees, who are probably much more civilized than themselves. In this last war, which was occasioned by mutual murders, they give no quarter: "Our war," said a Kharotee, "is not for power, nor for glory, but for blood."

The climate compels the Kharotees to be entirely 
idle in winter : cven their fire-wood is stored before the end of autumn, and their only business is to clear away the snow from their roofs, or to make roads through it from house to house. The poorer Kharotees, who cannot afford four months of idleness, are driven to warmer climates, and carry with them the greatest part of the bullociss and camels of the tribe. They only go as far as the southern valley of the Gomul, and return in spring to their own country; but upwards of three hundred families have renounced their share in the land, and have become as thorough wanderers as the Naussers. This has taken place within no long period of time, and some of the first shepherds are still alive. The Kharotees account for the change very rationally. Their fields, they say, are so closely hemmed in by steep mountains that it is impossible for them to extend their cultivation, nor does the deep shade of the pines with which the mountains are covered permit the growth of any herbage which might maintain their flocks. The natural increase of their population therefore reduced them to distress. The lands of each person were divided, according to the Mahommedan law, among his sons, and the portion which fell to the share of each was soon too small to maintain a man. Many, therefore, abandoned their land to their brothers, and betook themselves to pasturage. They have now no connexion with the country of the Kharotees, as they spend the winter in Damaun and the summer near Ghuznee; but their separation is too recent to have broken the ties which bound them to their clan : they still acknowledge the common Khaun of the Kharotees, and when they pass their native country in 
their annual migrations, their relations assemble and bring them berries, the seeds of the Jelghoozeh pine, and other produce of the mountains, for which the shepherds make returns in little presents from $\mathrm{Da}$ maun. The manners of these shepherds exactly resemble those of the Naussers, which I shall soon describe, but they are even more destitute of all the comforts of life.*

A few words will suffice for the Wurduks, I have mentioned that they are bounded on the west by the Paropamisan mountains, and on the other three sides by the Ghiljies. Their country is a long hollow between the hills (which separate them from Logur and Khurwar) and the Paropamisan mountains, the latter are penetrated by some deep valleys also belonging. to the Wurduks. The river, inaccurately named from Ghuznee, rises in the south of their lands, and runs through the centre of the whole of their extent.

The Wurdulss are all agricultural. They are a quiet, sober people, perfectly obedient to the King, to whom they pay revenue, and furnish a large portion of troops. They have no war with their neighbours, and their own Moollahs, or the King's Cauzy at Logur, settle their internal disputes.

What remains unmentioned of the country inhabited by the Afghauns, belongs to the tribe of Cauker. Surrounded by the Beloches, or by remote tribes of Afghauns, it is nearly inaccessible to inquiry ; and though I have obtained particular accounts of some parts of it, and have heard many vague rela-

* It is one of their camps which is described in the narrative page 40.

VOL II. 
tions from travellers respecting the remainder, my notions on the subject are still indistinct, and I must forego the attempts $I$ have litherto made at minute description, both with regard to the Caukers and their country.

The boundary of the Cauker country, on the north, is the same as the southern boundary of the Ghiljies : on the north-west it lias Urghessaun, the part of Toba which belongs to the Atchikzyes, and Pisheen; on the west, the country of the Beloches; on the south, that of the Speen Tereens; and on the east, the range of Solimaun and some of the little countries at its base, which have been already described. The whole forms a square of about a hundred miles.

The west of the Cauker country is mountainous. Its most distinguishing feature appears to be the range which $I$ have mentioned as s'unning north and south, between longitude $68^{\circ}$ east and longitude $69^{\circ}$ east. Wcst of that range, the first place in the Cauker country, coming from the north, is Seeoona Dang, (a high, cold, and barren plain, suited only to pasturage,) and the Cauker part of Toba, which, though more mountainous, probably resembles the part already described as belonging to the Atchikzyes. Further south, this high plain ceases, but there are many valleys in the hills, and Tor Murgha, Burshore, Nareen, Togye, and Hunna, are particularly conspicuous among those which open to the west. Still further south, the hills in question are only separated from the table-land of Kelaut by the narrow valley of Bolaum. The valley of Burshore deserves more particular mention. 
It commences at the source of the Lora, and accompanies that river till its entrance into Pisheen. The valley is sunk between the high country of Toba on the north, and the mountains on the south. The upper part of it is narrow, and filled with thickets, but the lower part is fertile, inhabited by an agricultural people, and abounding in all the produce of Khorassaun: were it not possessed by a different tribe, one would be disposed to consider it as part of Pislieen, from which district it has no natural separation. The valley of Hunna opens into Shawl. Its head is near the Cotul or pass of Chupper, where the road crosses over a very high ridge into Zawura.

Shawl itself deserves some notice in this place, as it is inhabited by a tribe of Caukers called Cassye ; but, as it was granted by Ahmed Shauh to Nusseer Khaun the Prince of the Beloches, for his service at the siege of Tubbus, it is no longer to be considered as part of the Afghaun country. It resembles Pisheen, but excels it in fertility. The Cassyes are under the Beloche government, but they have a Khaun of their own, and are well treated and flourishing. If any other valleys open to the west, they are neither distinguished for their inhabitants, nor for the passage of roads through them, but only afford a winter retreat to the Cauker shepherds.

To the east the mountains of $68^{\circ}$ longitude send out branches which divide the greater part of the tract situated between them and the range of Solimaun.

One range appears to run to the south of Zhobe, and to divide that country from Boree, but I do not believe it reaches any of the branches of Solimaun. 
Another runs to the south of Boree, divides it, for a certain extent, from Zawura, Tull, and Chooteeallee, and forms the southern limit of the Caukers. To the south of Zawura, Tull, and Chooteeallee, a broad belt of hills certainly stretches across from the range of $68^{\circ}$ to that of Solimaun, and forms the boundary of Afghaunistaun on the side of Seestaun.

I shall hastily review the districts included between these ranges, beginning from the south, and stretching north till I again meet the known countries of the Ghiljies and Dooraunees. But before I enter the mountains, it will be proper to mention the Caulier clan of Punnee, who inhabit Seewee in the plains of Secstaun; divided from the rest of the tribe by mountains and by Beloches, the inveterate enemies of the Caulier name.

Secwee is entered by a traveller from Dauder, in the course of lis first march to the northward. It is a flat, dry plain of hardened clay, but in some places its natural defects are relieved by streams from the hills, and round the town of Seewee, at least, is highly cultivated. The Punnees still form part of the Afghaun nation, and are under a governor appointed by the King. It would be curious to ascertain the causes which have sent them to this spot, and which lave filled the southern provinces of India with men of the Punnee clan, whose emigration (from the period when they figure in the listory of the Deckan) must have taken place some hundred years ago.

The mountains to the north of Seewee are inhabited by Beloches (as are the southern parts of the range of Solimaun), but in the hills to the south of Chooteeallee we find some independent Afghauns, 
principally composed of the remains of the tribe of Lonee, which at one period made a great figure in the transactions of India. The history of the Dilazauks may throw some light on the fortunes of this tribe, and it is remarkable that most of the tribes of Afghauns who have anciently been distinguished in India, have nearly disappeared from their native country. It is natural to conclude that they have not merely poured forth their redundant population (as the Eusofzyes have more recently done into Rohilcund), but have been driven from their original seats, and compelled to enter on the adventures to which they owe their reputation abroad.

Zawura, Tull, and Chooteeallee may be considered as one valley, widening at last into a plain. Zawura, the upper part of the valley, commences near Chupper, and to the north-east of Dozhuk, It is at first confined between the mountains, but soon expands sufficiently to admit of a degree of cultivation, and even of one or two very considerable villages.

Tull is still wider, and the cessation of the hills whicly bounded it on the north, allows the plains of Boree and Chooteeallee to unite. The soil of Tull and Chooteeallee appears to resemble that of Seewee, but the climate is more favourable, and the cultivation is, perhaps, more extended.

Boree is frequently compared, botls in extent and fertility, to the plain of Peshawer: I have no opportunity of judging of the justice of the comparison ; but it may be presumed that Boree is fertile and well cultivated, as it is certainly populous, and inliabited entirely by husbandmen. A considerable stream runs through Boree towards the south-west, and the land is 
watered by some other brooks, and by a considerable number of caureezes. The productions of the country, and the manners of the people, are still the same as have been described in Khorassaun, though the dress begins to resemble that of India:

Between the hills to the north of Boree, and those on the 68 th line of longitude, is Hindoo Baugh, the source of the river Zhobe. From this place the Zhobe pursues a north-easterly course, till it joins the Gomul at Sirmaugha. I imagine the Zhobe to be at first a small brook in a narrow valley; it never becomes a considerable stream, but in an early part of its course it divides an extensive plain, abounding in tamarisk, partially cultivated, and producing wheat, barley, rice, and some other grains, but principally given up to pasturage, and scattered with large and numerous camps of shepherds. Some accounts, indeed, represent the whole of the inhabitants as living in tents, while others describe a fertile tract, covered with cultivation and villages ; and these apparent contradictions can only be reconciled by supposing them to apply to different parts of this extensive district.

The lower course of the Zhobe is through the barren mountains which surround the Gomul, and which are all connected with the range of Solimaun. The valley of the Zhobe is probably bounded on the north by the range of hills which I suppose to form the southern limit of Seeoona Daugh.

The space included between the border of Zhobe, that of Boree, and the range of Solimaun, affords room for the lands of the Hurreepauls and Bauboors, and for the wastes pastured on by the Moossalshail and Esote Caukers. 
The hills through all the Cauker country are appropriated to the numerous shepherds, and those to the west of the country, so often alluded to, contain many valleys and little plains, of which some are well cultivated, but most are occupied by pastoral camps.

In so large a tribe as the Caukers, we can scarce expect uniformity of manners, and the less so as they are divided into at least ten clans, many of which are again broken into numberless independent societies; and there is no efficient chief of the whole tribe. The Caukers of Burshore so closely resemble the Tereens, that it is unnecessary to malie any further observation concerning them; but no other part of the tribe that I know bears an exact resemblance to any of these which have been described; an account of a district in the west, and another of one in the east, with some observations on the intermediate clans, will, however, give a sufficient idea of their peculiarities.

Cunchoghye is a narrow valley in the western face of the mountain of Kund. The soil is fertile, and in most parts well cultivated. In spring the whole valley and the adjoining hills are green, and covered with flowers; and the inhabitants are busily employed till the end of autumn in the cultivation of two harvests, and in the care of their sheep and cattle; but in winter a frost of three months, and an occasional fortnight of snow, oblige them to indulge in the usual idleness of the season.

The little valley of Cunchoghye by degrees expands to a considerable extent, and stretches towards the south-west for upwards of thirty miles. The wide part of the valley (which is no longer called by its 
original name), contains some villages of forty or fifty houses, round which there is a good deal of cultivation; but the greater part of it is occupied by shepherds and their flocks.

All the inhabitants form part of the clan of Sunnutteea, the possessions of which extend along the western frontier of the Caukers, from Zawura to Seeoona Daugh. This large division is under one chief, who enjoys a very ample authority over his clan, or at least over the part of it in the neighbourhood of Cunchoghye; his own seat is at Oorguss, two marches from that place, and still nearer to the source of the Zhobe. His powers are principally derived from the King. The grandfather of the present Khaun, being reduced to great distress from the aggressions of the Tereens, and from the faction and insubordination of his own clansmen, resolved to appeal to Ahmed Shauh (and presented himself before him (as be was lunting on Toba) with fire on his head, the symbol of extreme distress among some Asiatic nations.*

The Shauh instantly listened to his complaint, issued a Rukkum commanding obedience to his orders, and sent a small body of troops into the country of the Tereens. That tribe immediately forbore its attacks, and the Sunnutteeas, impressed with respect for the royal orders, and perhaps alarmed at the neighbourhood of the troops, submitted to the au-

* This practice is well known to all who are acquainted with the customs of Constantinople, as a certain method of procuring an audience of the Grand Seignior. The Afghauns explain it to imply that the misery of the petitioner is as great as if he were actually plunged in fire. 
thority of their Khaun, which his successors have been able to maintain unimpaired to this day. Their power, however, is perhaps confined to the northern part of their clan; for Tahmas Khaun, a subordinate chief in the south, has so far surpassed them in his actions and reputation, that it is improbable that he still submits to dependence on their authority.

This warlike chief principally obtained his distinction by the success of a war with the Beloches, who lad been exasperated by the border incursions, which had long subsisted between them and the Caukers, to attack that tribe in a manner which gave the expedition the appearance of a national war. Six thousand Beloches were assembled at Shawl by the orders of Nusseer Khaun, the Prince of the Beloches; and the Caukers, alarmed at this serious invasion, retired with their flocks to Dozhukh, a stony plain, elevated on the highest part of the mountains west of Zawura, difficult of ascent in all places, and on most sides surrounded by innccessible precipices. The Beloches, aware of the strength of this place on the side of Shawl, proceeded up the valley of Hunna, crossed the ridge of $68^{\circ}$ longitude, passed through Zawura, and advanced up a narrow valley, which afforded the only practicable route to Dozhulkb. Tahmas Khaun allowed them to advance till they reached the last steep ascent, when they were surrounded, attacked, and cut off almost to a man, with Fauzil Khaun, their commander.

However he may be regarded by Tahmas, the chief of the Sunnutteeas exercises great authority 
over the rest of his clan; he derives no regular revenue from it, but when he comes to a village he receives presents, which are sometimes valuable; and as he neither lives in any state, nor has any hired soldiers, these perquisites, with the produce of his own Iands, are abundantly sufficient to maintain him. As the Sunnutteeas have now no foreign wars, and as they pay no revenue, and have not for some years been called on for their contingent of horse by the King, the exercise of their chief's powers is confined to the administration of justice.

The adjustment of the less serious clisputes is left to the Mullik of the village, who has here great powers, and can inflict any punishment short of death ; but in all his proceedings he must have the support of the elders of the village, and he never attempts to take any step of consequence without the concurrence of a Jeerga. The Mullik of Cunchoghye receives a fixed allowance of grain from every man in the village.

Under so strong a government, it is natural that there should be little strife; and the few frays that take place never lead to the employment of any mortal weapon. Theft and rapine are hardly ever known, the disposition of the people is peaceable, and (to use the expression of a Cauker to me) they enjoy their own, and are content.

The shepherds near Cunchoghye are scattered in small camps of four or five tents, over the wide valley and the neighbouring hills. In some seasons they are compelled by the failure of the herbage to unite into larger camps, and to move to the country of other tribes; while in their scattered state, a whole camp only 
contains a single family, and they have much leisure, no restraint, no government, and yet no crimes.

The dress, manners, and customs of Cunchoghye differ in no respect from those of the wilder parts of the Dooraunee country; and they are said to be the same which obtain throughout all the western clans of the Caukers. I shall illustrate the state of the eastern Caukers by a short account of Boree.

The extent and fertility of this plain, and the temperate climate which it enjoys, have already been noticed; and if, as I am informed, even the sheep are fed, not on wastes, but on the fallow lands, cultivation must have made as much progress as it can well attain.

The produce is nearly the same as that of the western countries; European fruits are still common, but madder and clover are not grown, and lucerne is rare.

Except that camels are very scarce, the animals are the same as those of the west.

The inhabitants live in villages of terraced houses, and some move during the summer into cooddools, pitched at a short distance from their villages; the chiefs live in little castles.

The dress of the men is still a cameess, but they wear a loongee turban, instead of a cap, throw another loongee over their shoulders, and wear pointed shoes, like those of India: sheepskin and felt cloaks are extremely uncommon. Their manners and amusements are those of the west.

There are twelve independent communities in Boree, though the people are all of one subdivision of 
the clan of Sauraun. Each of these has several villages, which are under separate Mooshirs, and apparently unconnected with the chief of the whole, except when all are united by a war.

The villages are often at war among themselves; they sometimes refer their disputes to an umpire, but oftener to the arbitration of the sword. Even within the village, the Mooshir exercises but little control : he would call a Jeerga to settle a dispute which happened near him, but at a little distance things are left to take their course.

The other divisions of the Caukers probably resemble those of Cunchoghye or Boree, as they are nearest the east or west; but in the central parts of the country, they are much ruder than either. There they wear a short close jacket and breeches of felt in winter, and in summer go naked from the middle upwards. This would not be reckoned extraordinairy in India, but, as it is contrary to the notions of decency entertained by the Afghauns, it must among them be regarded as a proof of a great want of civilization.

In some places the Caukers are said to live in caves, like the Khyberees, but even there they are entirely destitute of the predatory spirit of the tribe which they resemble in the rudeness of their habitations. In most parts, the shepherds, who are far more numerous than the husbandmen, are scattered in little camps, as in the west, but in Zhobe they are said to assemble in camps large enough to be described as towns of tents. There they are also said to keep almost as many oxen as sheep, and, if so, they are the only instance of wandering herds- 
men in Afghaunistaun. On the whole, the greater part of the Cauker country is mountainous and infertile; and the inhabitants are shepherds, rude in their manners, and ignorant of the arts of life; but simple, peaceable, and inoffensive. 


\section{CHAPTER VI.}

THE NAUSSERS.

AcL the tribes who have as yet been considered, possess some country of their own, the position of which has decided the order in which they were to be mentioned; but the Naussers have no land at all, and we are left at liberty to place them wherever it suits our convenience. They are chiefly distinguished from the other tribes by their wandering life, to which my observatious shall, therefore, be confined.

In spring we find them scattered in parties of three, four, or five tents, over the wastes in the countries of the Tokhees and Hotukees. Later in the year, they assemble in camps of one or two hundred tents, move about by short stages in quest of grass for their flocks; and as soon as the autumn begins to close, they hold their councils, strike their tents, and set off on their long migrations to the warm plains of Damaun.

The tribe marches through the hostile country of the Vizeerees in two divisions, and it is settled by the Khaun and the Mooshirs which is to march first. The rendezvous for each division is at Kunzoor on 
the Gomul, to which place all the hordes direct their march from their different Eilaulss in Khorassaun. In the beginning of this march, they pass through barren wilds, where they see nobody but their own companions; but as they approach Kunzoor, the roads are cholsed with other hordes flocking from various and distant stations to the rendezvous. Great confusion now arises; two hordes which are at war, are often crowded together in one narrow valley, and new quarrels are also occasioned by the impatience of different parties to get first through the passes in the hills. At last they join the confused mass of tents, men, and cattle, which are heaped together at Kunzoor.

The whole assemblage amounts to more than thirty thousand people, with all their numberless flocks and herds of camels, and indeed with all their possessions. The bustle and disorder of such a throng may well be conceived.

During the day, they issue forth in swarms to search for forage and fire-wood; and at nightfall, these unfrequented valleys resound with the confused voices of the multitude, the bleating and lowing of their flocks and herds, the hoarse roar of the camel, and the shouts and songs of the Naussers.

When the whole division is assembled, Chelwashtees are appointed, and they renew their progress towards Damaun.

The Vizeerees, in the mean time, are preparing for their reception with all the caution and secrecy of savage war; their clans are assembled in the depths of the mountains, and a single scout, perhaps, watches on the brow of a rock, and listens in the silence of 
that desolate region for the hum of the approaching crowd, till at length the Naussers are heard, and the valleys are filled with the stream of men and flocks that pours down the bed and banks of the Gomul. The word is then passed round to the Vizeerees, who hasten to the defiles by paths known only to themselves, and attack the disorderly crowd, or lie in ambush to cut off the stragglers, according to the remissness or vigilance they observe among. their enemies. During this time of danger, which lasts a week or ten days, the Naussers are in an unusual state of preparation; the power of the Chelwashtees suppresses all feuds, and arranges the order of march, and the means of defence; the whole division moves in a body; parties of chosen men protect the front, the flanks, and the rear, while the other Naussers drive on the sheep and camels, and hold themselves ready to repel any attack that may be made by their enemies. They had need, indeed, to be prepared, for the predatory disposition of the Vizeerees is sharpened by long enmity; and they give no quarter to any Nausser that falls into their hands. At length they reach the pass of Zirkunnee, issue out into the plains, and are spread over the whole of Damaun from the frontier of Upper Sind to the hills of the Murwuts. Each horde has a particular tract where it is accustomed to encamp, and round which it ranges as the supply of forage requires. They encamp in circles, within which they shut up their cattle at night. Their life is now idle and unvaried, except when enlivened by hunting, which they keenly pursue, and which is almost their only active employment. The women do all the 
labour, pitch the tents, gather the wood, bring in water, and cook the dinner; the men only saunter out with the sheep and camels, and for this labour a vel'y few men suffice. The rich hire out their cattle during their long halts, but the owner makes over the duty of accompanying them to some poor man, who gets a third of the hire for his labour.

The women are never concealed; but the same chastity and modesty which distinguish all rude tribes is common among them.

When the snow has melted on Solomon's throne, the chicfs of the Nausser camps send to the Khaun of the whole, to fix a time for a council : on the appointed day they all repair to his camp, determine theil route, appoint Chelwashtees, and soon after break up their camps, and commence their return to Khorassaun.

The Naussers, as has been seen, depend entirely on their flocks and herds; the fleeces of their sheep supply the materials for their tents, their carpets, and the sacks which hold their flour; their posteens and some other articles are made of sheep-skins: the mill of the ewe affords the cheese, butter, and croot, which is their usual diet, and its flesh is their only luxury.

The produce of their sheep, and the hire of their camels, also furnish the means of obtaining the few articles they require from without; and the carriage of their tents and other property, which are so material to wandering people, is entirely performed by the camels. Their sheep and camels are extremely numerous, and every part of their economy is adapted to

VOL. II. 
the moving life which is necessary to feed such a number of animals : their tents are small and light: their whole property is a suit or two of clothes, a few sacks of flour, with half a dozen earthen pots, and one or two of brass.

Their dress is between those of the east and the west, but their loose white turban seems to make it most resemble the former.

In their persons they are small, black, and ugly: they are barbarous in their manners, and rade and squalid in their general appearance.

They are, however, a remarkably honest and harmless people.

They are reckoned to amount to 12,000 families. Their govermment resembles that of the independent tribes, a circumstance which at first excites some surprise in a people entirely pastoral, but which is perhaps to be accounted for by the peculiarity of their situation. The effect of pastoral habits in introducing despotic power, has long been observed by writers on the history of human society, and their opinions have been strengthened by the example of alnost all the tribes of ancient Scythia and modern Tartary; but this obscrvation, and the reasonings of their authors who support it, appear to be derived from the practice of countries entirely pastoral, inhabited by several distinct and independent nations, where the simultaneous increase of the flocks of different tribes compels each to extend its limits, and leads to wars, which oblige each tribe to encamp and march in a body, and to secure the co-operation of all its parts by implicit submission to a common head. These reasons do not exist in a tribe placed in a kingdom 
chiefly inhabited by husbandmen, and feeding its flocks on waste lands at a distance from those adapted to agriculture; and for this reason perhaps it is that we find the Naussers enjoying the same liberty as most of the other Afghanns. The established government and the habits of the nation secure their peace, so that when stationary they scatter over an extensive tract, according to the inclination of each individual, and live almost entirely free from the restraint of government, while the temporary appointment of a Chelwashtee is sufficient to provide for the order and safety of their marches. The actual situation of the chief of the Naussers appears to me to afford proofs of the truth of this supposition. When the people are collected into camps, they are governed by their own Mooshirs, without any reference to the Khaun, and when they are scattered over the country, they subsist without any government at all; but when a march is contemplated, they immediately look to the Khaun, and where they have to pass an enemy's country, he is appointed head of the Chelwashtees, assumes an absolute authority, and becomes an object. of respect and anxiety to all the tribe. A proof of the importance of the Khaun during a march, is shown by the conduct of the Naussers at one time when Jurrus Khaun, their present chief, refused to accompany them in one of their migrations. He was anxious to remain in Damaun with 200 or 300 of his relations, to assist Surwur Khaun against the Vizeerees; but his resolution occasioned great distress in the tribe, who declared it was impossible to march without their Khaun. So earnest were their representations, that Jurrus was at last compelled to aban- 
don his former design, and to accompany them on their march to Khorassaun.

The Khaun and all the Mooshirs are elected from the head families, and would be deposed if found unfit for their offices. The Mullik (or Mooshir) settles all disputes, and can expel an offender the camp without a Jcergat he is also absolute with regard to the muvements and stations of the camp ; but any four or five people may go and advise him on that head, though, if lie is resolved, they must abide by his decision.

The Nanssers pay a tax to the King, which is at present allotted to Abdooreheem Khaun, and this circumstance appears to countenance a pretension which they often advance to a connection by blood with the Hotukees. The Hotukees say that the Naussers have been their Humsauyehs, but not their kindred : some even represent them as sprung from the Beloches; and though they speak Pushtoo, and strenuously maintain their descent from the Afghauns, their features and appearance certainly indicate a race distinct from that nation. 


\section{BOOK IV.}

PROVINCES.

\section{CHAPTER I.}

BULKH OR BACTRIA, AND THE UZBEKS.

Having completed my account of Afghaunistaun, I shall describe the other provinces and dependencies of the kingdom of Caubul. In this description I shall preserve the order in which they stand geographically, that relation being more permanent and more interesting to the reader than their fluctuating connection with the Dooraunee government. On this principle, I shall begin from the north; and, after describing Bulkh, shall proceed, by the Eimauks and Hazaurehs, to Heraut ; from which I shall pursue a south-easterly course, through Seestaun and Belochistaun, to Sind, and thence return towards the north, till I reach Cashmeer and the countries which connect that celebrated valley with the lands of the Berdooraunee tribes.

I have before alluded to the difficulty of naming the Afghaun province in Toorkistaun. Nor is it easier to determine the extent of the country which ought to be comprehended within its limits. At present, the only actual possession of the Afghauns in 
Toorkistaun is the district immediately round Bulkh; but the possessor of that city has always been considered as the rightful master of its dependencies, which include the tract having the Oxus on the north, the mountains of Hilldoo Coosh and Paropamisus on the south, Budukhshaun on the east, and (generally spealking) the desart on the west. The extent of this tract nay be near two hundred and fifty miles in length (from east to west), and from a hundred to a hundred and twenty miles in breadth (from north to south).

The southern part of this country is full of hills, connected with Hindoo Coosh. These are generally stony, but have many good and well-watered valleys. The neighbourhood of the hills secures a supply of water to the central part of the country, which is plain and fertile. The north towards the Oxus is sandy and barren. The east of the province, being near a mountainous country, is better than the west, which borclers on the desart, and partakes of its nature.

The descent from the great range of mountains is very rapid, and the lower parts of Bulkh towards the Oxus are much lower and hotter than those parts of Afghaunistaun which lie immediately to the south of the range. The province of Bulkh is famous for a strong and active breed of horses, which are exported in considerable numbers.

The whole province is divided into several districts from various causes. Some, though now united, have formerly been under different governments; and others have lately separated that formerly were one. The existing divisions are as follows (beginning from the 
west):-Meimuna, Andkhoo, and Shibbergaun; Bulkh Proper $(i . e$. the country immediately round the capital), Khoolloom, Huzrut Imaum, Koondooz, Khost and Inderaub, Taulikaun.

The three first cantons are of small extent and little consequence : though bordering on the desart, and perhaps deficient in water, their soil is good, and they might be brought under cultivation; but they are at present chiefly occupied by wandering shepherds of the Uzbek and Toorkomaun nations.

Bulkh requires further notice. The city which gives its name to the district is of the highest antiquity. It was lsnown to the Greeks in the time of Alexander by the name of Bactra; but it had been the capital of Persia at a far earlier period, laving. been fixed on as the royal residence by Ky Khoosroo, supposed to be the same as Cyrus the Great. All the Asiatics are impressed with an idea of its being the oldest city in the world, and in consequence distinguish it by the title of Omool Belaud, the mother of towns. This ancient metropolis is now reduced to insignificance. Its ruins still cover a great extent, and are surrounded with a wall, but only one corner is inhabited. Part of it is occupied by the citadel, where the Dooraunee governor resides, and which is inhabited by a few of the royal troops, and by some Hindoo dependents.

The country round the city is flat, fertile, and well cultivated. It is said to contain three hundred and sixty villages, and is watered by eighteen canals drawn from a celebrated reservoir (called the Bundee Ameer) in the Paropamisan mountains. I can give no particular description of these canals, but they must be 


\section{KITOOLLOOM-IIUZRUT IMAUM-IKOONDOOZ.}

considerable, and must water much cultivation, as one of them which has been granted by the King to a son of Meer Killich Ali, is reckoned to produce an annual revenue of seventy thousand rupees, which is nearly nine thousand pounds sterling. The west of this tract is covered with thick and deep woods of reeds, which, though complained of by the traveller, bespeak a rich soil and a well-watered country. What I have said must not be extended to the northern part of the country under Bulkh, which is sandy and barren as far as the Oxus.

Khoolloom, which lies south of Bulkh, is much more hilly and barren. Taush Koorghaun, its capital, is, however, a place of consequence, and contains near eight thousand houses.

Huzrut Imaum, which is now annexed to Khoolloom, is a poor and sandy country.

Koondooz is chiefly flat, though the southern part is occupied by hills stretching from Hindoo Coost, and forming many rich and beautiful valleys stocked with fruits of various kinds. The plain part of Koondooz is also very fertile, and watered by numerous streams from Hindoo Coosh. The country round the town, in particular, is cultivated like a garden, and is subject to inundation. The capital is a good town, and exceeds Taush Koorghaun in extent. Khost and [nderaub are small and mountainous, but fertile countries, on the northern face of Hirdoo Coosh. They are inhabited by Taujiks, and are now annexed to Koondooz.

Taulikaun is a narrow and hilly country in the north-east of Bulkh, and contiguous to Budukhshaun. It is, however, fertile and well inhabited. 
The ruling tribe of Bulkh, and indeed the principal part of the population, belong to the Uzbek nation. I shall, therefore, give some account of that people, without confining my observations to the part of it which inhabits the country under discussion; to whose local peculiarities I shall afterwards return.

The Uzbeks first crossed the Jaxartes about the beginning of the sixteenth century, and, pouring on the possessions of the descendants of Tamerlane, soon drove them from Bokhaura, Khoarizm, and Ferghauna, and spread terror and dismay to the remotest parts of their extended empire. They now possess, besides Bulkh, the kingdoms of Khoarizm (or Orgunge), Bokhaura, and Ferghauna, and perhaps some other little countries on this side of Beloot Taugh. I am told that they are to be found beyond Beloot Taugh, and as far east as Khoten at least; but of this I cannot speak with confidence. They belong to that great division of the human race which is known in Asia by the name of Toork, and which, with the Moguls and Manshoors, compose what we call the Tartar nation. Each of these divisions has its separate language, and that of the Toorks is widely diffused throughout the west of Asia. The Uzbeks, the natives of Chinese Tartary, as far at least as Khoten, and perhaps as far as Karrakoorrum, the Kuzzauks, * and other tribes beyond the Jaxartes,

* These Kuzzauks, who are a tribe of Toorks, must not be confounded with the Cossacks of the Don and the Black Sea, who seem to be factitious societies, formed from the neighbouring nations. The Uzbeks, who have hearc of thesc last, call them Kuzznuk-Ooorooss, or Russo-Cossacks. 
most of the inhabitants of Kipchak and Crimea, the Toorkomauns, and the ruling nations of the Persian and Turkish empires, speak Toorkee as their vernacular language: it is to be found in scattered words throughout Russia, and in whole classes of terms in the languages of Caubul, and Hindoostaun. It is thought to be spoken in most purity in Ferghauna. The speech of Turkey is notoriously corrupted by the intermixture of foreign terms; that of Persia has also suffered from the great use of the original language of the country among its Toorkee conquerors; and even the Uzbeks of Bokhaura are supposed to have refined and enriched their tongue at the expense of its purity.

Nothing can exhibit a more striking contrast to the government of the Afghauns than that of the Uzbelss. In Bokhaura and Fergbauna, at least, every thing is in the hands of the sovereign; there is no vestige of popular government, and scarcely any trace of aristocracy. The Uzbeks of those kingdoms are every where divided into Oorooghs, or tribes, but that division has no relation to the government: no separate jurisdictions exist even in the wandering hordes. There are no assemblies of the tribe, or its elders, as among the Afghauns, either for the conduct of its affairs, or for the settlement of disputes.

The country is divided into districts, under officers appointed by the sovereign. These are subdivided into smaller clistricts, in which the revenue is collected and justice administered by inferior officers. Subordinate to these are village governments, such as are found all over the east; and here, at length, some 
symptoms of popular influence and of attention to birth appear in the appointment of the Auksekaul, or head of the village. That officer is named by the sovereign, at the recommendation of the richest people of the village, and though their selection is influenced by the wealth and abilities of the candidates, yet they often continue the office for a long time in one family. The power of the Auksekaul is, however, inconsiderable; he is, indeed, rather an agent employed by the villagers than an officer on the part of the King.

Besides this chain of civil officers, and those who have commands in the army, the only people of consequence among the laity are those called Baues, whose authority and influence are entirely derived from their wealth. In like manner, in the army, every thing depends on the appointment of the government. We find Meengbaushees, Euzbaushees, Choraghaushees, (commanders of a thousand, of a hundred, and of ten,) which show that the division of the army is arbitrary, and does not proceed on the principle of leaving the contingent of each tribe, clan, or village, under its hereditary chief.

In Bokhaura, incleed, the men are said to be told off into messes of ten each, who have a tent, a boiler, and a camel between them, an arrangement in which it is evident that neither family connection nor individual freedom are at all regarded.

The Ulima, or members of the church, alone possess any influence not derived from the government, but their weight is very considerable.

The Uzbeiss had probably few laws or institutions 
of their own at the time of their conversion to Islaum, for they have adopted the provisions of the Mahommedan system in its utmost detail, applying it to every part of their civil government, and even of their private conduct. The revenue is collected exactly in the proportions directed in the Koraun, and one-tenth of its produce is applied to alms. Justice is administered by the Cauzy in strict conformity to the Shirra; and drinking wine, or even smoking tobacco, is as strictly forbidden, and almost as sevverely punished, as fraud or robbery. The King of Bokhaura's title is Commander of the Faithful; part of every day is spent by him in teaching the Mahommedan religion, and the greater part of every night in prayers and vigils. The same King reads prayers in his own mosque, and often performs the funeral service even for people of low rank; and Killich Ali $\mathrm{Beg}$, the present ruler of Bulkh, always walks in the streets; lest, if he rode, his feet might be higher than the heads of other true believers.

The great difference between the government of the Uzbeks and that of the Afghauns afforcls a field for speculation which could scarcely fail to be instructive : my information is too incomplete to allow of my attempting to account for it, even if I were otherwise qualified for such a task. It may, however, be observed, that the causes which have already been alludecl to, as conferring so much power on the chiefs of all Tartar tribes, must have operated to render the Uzbek people submissive; and the only difficulty is to ascertain how their obedience was transferred from those chiefs to the general governments. In the case of Bolkhaura we find that this was the result of a long 
exertion on the part of the government, which is stated to have, from ancient times, practised the policy of dividing and mixing the various tribes under its authority, and of keeping the great men from all employments that might give them influence over the people with whom they were connected by birth. It is probable some such policy was adopted by the other Uzbek governments, and several conjectures may be offered as to the means they possessed for carrying it into effect.

The Uzbeks entered their present seats as conquerors, and the power which their leader necessarily enjoyed while they were an army, continued when they again became a fixed nation. It is probable his power was strengthened by the Moollahs, who are generally the allies of the civil government, and whose aid in this case would be more than usually powerful :* and finally the country possessed by the $U_{z-}$ beks is generally plain, and consequently unfavourable to the preservation of the independence of small societies. The effect of this last circumstance in establishing the power of the general government is great, as we may judge from the state of the Uzbeks who inhabit strong countries. The hilly country of Hissaur, and the marshy one of Shelir Subz, being equally inaccessible to the cavalry of the King of Bolshaura, have alike defied his power, and remain under the chiefs of the tribes who inhabit them; but in all those states the people are equally

* This alliance with the civil government tends also to increase the power of the Moollahs. It was probably in consequence of a combination of this lind, that the Ulima of Constantinople acquired the great power they possess. 
enslaved, and among the whole Toorkes race, the Toorkomauns on the Oxus alone enjoy a pojular goversment.

The Uzbeks of Bulkh, who in all other circumstances resemble those beyond the Oxus, differ in this particular, that they are assembled in tribes under powerful chiefs. This peculiarity is probably occasioned by their being separated by mountains from the kingdom of Caubul, to which they belong, and from their bordering on the rival state of Bolkaura; which circumstances combined have prevented any encroachment by their own sovereign on the rights of the local chiefs : the people, however, are as subservient as elsewhere.

The Uzbeks are generally short and stout men. Their national features are broad foreheads, high cheek-bones, thin beards, and small eyes. Their complexion is clear and ruddy, their hair is generally black. The beauty of the 'Toorks is constantly spoken of by Persian poets, and though that quality does not strike us in their appearance, yet they unust be allowed to possess it, when compared with the hideous physiognomy of some of the other Tartars, whose long narrow eyes pointing upwards, together with the blackness of their complexions, give them an appearance scarcely human.

Their dress is a shirt and trowsers of cotton, a coat or tunic (called chuppaun) of silken or woollen cloth, tied on with a girdle; and over it a gown of woollen cloth, posteen, or felt. Some wear in winter a little cap of broad cloth, lined with fur, sitting close to the head, and others a pointed silken cap, called a calpauk, alone; but the national head-dress is a large 
white turban, worn in general over a calpauk. All wear boots at all hours; the poor have the same description as that used in Caubul, but those in easy circumstances have a kind called mulusee for constant use, and only put on the others in winter or on journeys. The muliusee is of thin and light sha. green leather, without heels or soles, so that the wearer is obliged to put on shoes when he goes out. All wear bandages ruund their legs instead of stockings; and every man las a knife hanging from his girdle, and a flint and steel for striking fire.*

Even the women wear boots. The rest of their dress is something like that of the men, but longer: they tie a silk handkerchief round their heads, throw a sheet of silk or cotton over all; wear golden and silver ornaments, and plait their hair into a long quene, which hangs down from the middle of the head like those of the Chinese.

The Uzbeks breakfast on tea and leavened bread, which, contrary to the usual practice of Asia, they eat stale, and keep for a fortnight. Their tea is made by boiling the leaves: it is mixed with milk and butter, or, more frequently, the oil made from the fat tails of the Doombeh sheep. The rich alone use sugar. The great meal is in the evening, and consists of pilaw, or flesh and broth, like that of the Afghauns. The rich, of course, have a variety of dressed dishes. The Uzbeks are known to be fond

* The plate represents the dress of the Uzbelss near towns. The face and figure is a good likeness of Mahommed Hussun, a native of Wurdaunzye, near Bolkhaura, whose father was an Uzbek, and his mother a Syud. An Uzbel of pure descent would perhaps have harsher fentures, and one who inhabited the desart, ruder garments. 
of horse-flesh, but as that food is expensive, they are in general obliged to be content with beef. 'The wealthy indeed fatten horses for the table all the year, and the poor generally get some of the same sort of provisions during winter.

The national beverage is kimmiz, an intoxicating liquor, well known to be prepared from mare's milk. The milk is put in the afternoon into a skin, such as is used in India for holding water, and is allowed to remain till within two or three hours of day-break, when it is beaten and rolled about till morning at least; but the longer the better. The liquor thus made is of a whitish colour and a sourish taste: it is only to be had in plenty during the two last months of summer, and those who can aftord it are generally drunk for the greater part of that period; but kimmiz is not sold, and those only can enjoy it who have mares enough to make it in the house. Another intoxicating liquor, called bozel, is more cheaply procured, but it is far more strictly forbidden: it is a fermented liquor made from different grains (particularly from Arzun), which resembles water-gruel in appearance, and is sour to the taste. It is also known in India and Arabia. Notwithstanding the use of these liquors, the Uzbeks are generally a sober people.

Part of the Uzbels live in houses, and part in camps. Their houses, villages, and towns exactly resemble those of the Afghauns, but their tents are widely different. The Uzbek tent is of the kind called Khirgah, which appears to be in use over all Tartary, in part of Persia, and even in part of China. It is round, and formed of lattice-work of thin laths, 
covered with black or grey felts. The roof is of four stouter laths, bent into the shape of a dome, and held together by a round piece of wood in the middle. The Khirgah far surpasses the black tent of the Afghauns, both in warmth and shelter, and it is scarcely more difficult to carry. It is commonly called by the Toorks, Karraooe, or black house : a camp is called Ouool, and consists of twenty to fifty tents.

A great part of the people of Bolkhaura reside in tents, and follow pasturage, to which indeed they are compelled by the unproductive desarts of which so much of their country is composed. Ferghauna, a richer country, which is secure of water from the neighbourhood of mountains, has few wandering tribes. In Khwarizm, and the countries between Bokliaura and the Caspian Sea, the wandering tribes greatly preponderate; but in the province of Bulkh they are very inferior to the fixed inhabitants: they breed sheep, camels, and horses; and so numerous are the latter, that there is scarcely a man in Toorkistaun so indigent as to walk on foot; even beggars travel on horseback, or at least upon camels and asses. As might be expected in such a people, the Uzbelss produce swarms of light cavalry, and are renowned for their exertions in predatory war. Their arms are a long and heavy lance and a shield ; few have swords, but many long knives or daggers. They charge in a body with shouts, which the Afghauns, who have engaged them, describe as loud and terrific. They form their armies in three divisions, so that they can rally twice; but the third repulse is entire defeat. They make brave soldiers, and are astonishingly patient of hunger, thirst, and fatigue.

VOL. II. 
The opinion commonly entertained of the ferocity and barbarism of the Uzbeks appears to be unjust, and is probably owing partly to our confounding them with the Calmuks and other rude Tartar tribes hetween them and Russia, and partly to the channels through which we have received our information regarding them. Their habit of selling slaves might have justified the prejudice against them, but this detestable traffic unfortunately was not confined to the Uzbeks. Their laws of war are certainly most barbarous. They give no quarter to any enemies but Sheealss or inficlels, whom they can sell for slaves, and men are sold in Bokhaura like cattle; but in other respects, by all that I can learn, both from Afghaun travellers, and from Taujiks of Bulkh and Bokhaura, I have reason to think the Uzbels as good a people as any in Asia.

They are said to be comparatively sincere and honest. They have few quarrels among individuals, and scarcely any murders; and there are few countries in the East where a stranger would be more at ease. Those who imagine the Uzbeks to be savage Tartars, wandering over wild and desolate regions, will be surprised to hear that the city of Bokhaura is equal in population to Peshawer, and consequently superior to any in England, except London. 'That it contains numerous colleges, which might accommodate from 60 to $600 *$ students each, and which have professors

* The college of Kolkul Taush, for instance, has 300 apartments, in each of which two students can be lodged. This account of the colleges, and some other information of which I have availed myself, is contained in an account transmitted by Meer Izzut Oollah's agent at Bokhaura, in a letter dated April, 1813. I must, however, guard 
paid by the King or by private foundations; that it abounds in caravanserais, where merchants of all nations meet with great encouragement; aud that all religions are fully tolerated by a prince and people above all others attached to their own belief. I now return to the history and present state of the province of Bullkl.

Besides the Uzbelss, there are many Taujiks in Bulkh, and many Arabs, who, though they now speak Persian, are still distinguished from Taujiks. Some few of the Arabs, however, retain their language.

The best accounts I can obtain, assign to the whole of the country to which $I$ have applied, the name of Bulkh, a population of one million.

Bulkh was conquered by Naudir Shauh, and seems to have fallen into the hands of Ahmed Shauh with little difficulty, and without the necessity of going against it in person. The city of Bulkh, and the country round it, where the only parts in the King's immediate possession; but all the Uzbek chiefs in the province, were in complete subjection to his authority, and even Budukhshaun is said to have paid him tribute. Before the death of Ahmed Shauh, or early in the reign of his successor, the chief of Koondooz threw off the Afghaun yoke, and successfully resisted three armies that were sent against him, though the last was of considerable strength, and

the reader against imagining that the colleges are at all like those of Europe. The sciences principally studied are theology and Mahommedan law, and in most of those which we value, the Uzbeks are far behind the Afglauns. Medicine, for example, is practised by travelling physicians brought up in other countries, and many people of Bolhaura come to Peshawer for education. 
commanded by Sirdauri Jehaun Khaun, the best general of the school of Alsmed Shauh. While Timour Shauh was at Bulkh in 1789, before his campaign against the King of Bolshaura, he compelled the chief of Koondooz to pay tribute, but was prevented effectually reducing him by the important war in which he was engaged. After this campaign, Bulkh appears to have been neglected, and to have suffered many calamities. The province was invaded, and the capital besieged by Shauh Moraud, King of the Uzbelss, and at one time the whole province, except the city of Bulkh and Khoolloon, was reduced under the authority of Allaverdee Khann Tauz, the chief of an independent Uzbel tribe, whose original possession was Koorghaun Tippel, on the northern bank of the Oxus. Bulkh was defended during that period by the Dooraunee Haukim, and Khoolloom by Killich Ali Beg, who was then beginning to rise to the importance he has since attained.

Killich Ali was descended from the chiefs of Khoolloom, and held the Uzbek title of Ataulik (equivalent to Vizeer) from the King of Caubul; but at his first accession to his government, he found his power very circumscribed. Flis abilities, however, soon enabled him, first to reduce his rebellious subjects, and afterwards to annex the petty states of Eibuk, Ghoree, Mozaur, Derra Guz, \&c., which lay in his neighbourhood to his own territory. He afterwards took the principal sliare in the expulsion of Allaverdee Tauz, and acquired the country of Huzrut Inaaum, which he delivered from that chief; on the same occasion, he gained an ascendancy in Koondooz, which he helped to deliver. He connected himself by marriage with 
the chief, and has since managed so dexterously, that Khaul Daud Khaun of Koondooz, though he possesses more power and resources than Killich Ali, is as much under his influence as one of his own deputies. He next made use of his power on the spot, and of all his influence at court, to acquire an ascendancy over the Haulkim of Bulkh; and as he had always been a zealous and useful servant of the crown of Caubul, he contrived, by seizing favourable occasions, to procure the transfer of some of the Haukim's powers to himself, and even to obtain the King's countenance, or connivance, in the open resistance which he offered to that officer. At length, in the year 1809, Prince Abbass, the King's nephew, who had escaped from confinement at Caubul, fled to Bulkh, and was received and supported by the Haukim. It may be supposed that Shauh Shujal was ready enough to issue orders to Killich Ali to act against a pretender to the throne ; and, accordingly, Killich Ali attacked and expelled the Haukim, and since that time he has had more real power in Bulkh than the King. 'The Dooraunee Haukim continues in posses. sion of the city and its dependencies, but he is chiefly supported by Killich Ali ; and all the rest of the province, except Taulikaun, is either under the government or the influence of the same chicf.

The King derives no benefit from the town, the revenues of which are consumed in grants to learned and religious men, in pensions to persons of other descriptions, in the expenses of the Haukim, and in the pay of the Cohneh Nokur, a description of troops peculiar to this province. They were originally raised at Caubul for permanent service in Bulkh, which, 
from the vicinity of the frontier of Bokhaura, always required a strong force. Not less than five thousand have been entertained from first to last, but the service was so unpopular, that although a bounty of five tomauns (equal to 10l.) was given to recruits, none but the lowest orders would enlist; and even of them so many have returned to Caubul, that the number of the Colinel Nokur is now under one thousand families. They are paid by assignments of land, which descend from father to son; and from the interest which this gives them in the country, they have acquired almost all the feelings of the natives. They bear much the same relation to the King that the Janissaries of Syria do to the Porte; and if Killich Ali Beg were to rebel, they would be more likely to adhere to him than to their own government.

This, however, is not an event very jilkely to happen, for though Killich Ali may be regarded as an independent prince, he is never deficient in respect to the King; and as the only advantage that monarch ever derived from Bulkh, was the protection of his frontier from the Uzbeks, he is probably not ill pleased to see the control of it in the hands of a chief so able to maintain its tranquillity, and so willing to acknowledge his dependence.

There are few princes in this part of Asia who enjoy so extensive and so well merited a reputation as Killich Ali. A traveller towards the west from Hindoostaun, hears the praises of his good government from the caravans long before he reaches the Indus; and all merchants who have passed through his country, speak with equal applause of the exemption from 
duties which he allows, and of the effectual protection he affords.

His army may consist of about twelve thousand horse, of which two thousand are in his own pay, and the rest are furnished by men who hold lands of him, on condition of military service. He could also draw about five thousand men from Koondooz. His revenue, after deducting the expense of his army, may be estimated at a lack and a half of rupees-about 19,000l. His eldest son had a grant of 9000l. with the title of Waulee, or Prince of Bullkh, from the King of Caubul. He is the head of the Uzbek tribe of Mooitunn, which includes the principal part of the inhabitants of Khoolloon. The following account; of his person and manners was communicated by the Resident at Dehli's agent, mentioned in a note on a former page.

Killich Ali Beg is about sixty years old; he is a handsome man, with a red and white complexion. He has a few grey hairs on his chin for a beard, small eyes, broad forehead, and Uzbek attire. On his head he wears a cap, and over it two turbans twisted up together. He wears an Uzbek shirt and a gown, over which is a girdle, wound round his loins, with a long knife stuck in it; and over the whole he generally has a robe of cotton or other cloth of some sober colour, such as ash-colour, or the like. He does not always wear boots, or muhusees, as the other Uzbeks do, but only when he rides; he carries a short stick in his hand, and takes a great deal of snuff.

He takes his seat in his public apartment every 
day about two hours after sun-rise. He sits on a carpet without pillows or cushions; his intimates, and those to whom he wishes to do honour, sit on the same carpet with him; but all other persons who come to him on business sit on the bare ground. Every man, as he enters, says Salaum Alaikoom, before he takes his seat. He inquires into every affair connected with the administration of the government himself; but those which involve law questions, he refers to the Cauzy. He does not put thieves to cleath, but hangs them up by the hand on an iron pin, fixed in a wall in the midst of the market place. Highway robbers and murderers he always put to death. He walks on foot through the bazars, and examines them every market day. He has more than once discovered light weights and overcharges by means of his own penetration, and he has now made regulations to prevent those abuses in future.

Killich Ali is honest, just, well disposed, kind to his subjects, judicious and discriminating in his treatment of his servants, economical in his expenses, vigilant and well informed in the affairs of his government. He gives bread and broth to a hundred poor persons daily.

Koondooz belongs to the Uzbek tribe of Kuttaghunn, the chief of which is Khauldaud Khaun. He could raise fifteen thousand men, and his revenue is about $30,000 l$.

Taulikaun is possessed by a small but warlike and independent tribe of Uzbelss, who molest the neighbouring countries of Koondooz and Budukhshaun with their incursions. They are too weak to make con. 
quests, and too spirited to submit themselves to a conqueror. Meimuna Andkhoo, Shibberghaun, and some other little districts, are independent, most of them under Persian chiefs, and with Persian inhabitants.*

[*The city of Bulkh has now fallen into the hands of the King of Bokhaura. Killich Ali is dead, and his sons, with all the other cliefs of the province, ns well as the adjoining country of lhulukbshaun, are completely subject to the Khaun of Koondooz. For these events and a complete account of the Uzbeks, see Burnes Trarcls. -1838.] 
Thе Eimauks and Hazaurehs have been stated to inhabit the Paropamisan mountains between Caubul and Heraut, having the Uzbelss on their north, and the Dooraunees and Ghiljies on their south. Their countries have been stated to be rugged and mountainous. Both united extend more than three hundred miles in length, and about two hundred miles in breadth.

One is surprised to find within the limits of Afghaunistaun, and in that very part of it which is said to be the original seat of the Afghauns, a people differing entirely from that nation in appearance, language, and manners. The wonder seems at first removed, when we find that they bear a resemblance to their Toorkee neighbours, but points of difference occur even there, which leave us in more perplexity than before. The people themselves afford us no aid in removing this obscurity, for they have no account of their own origin; nor does their language, which is a dialect of Persian, afford any clue by which we might discover the race from which they are sprung. Their features, however, refer them at once to the Tartar stock, and a tradition declares them to be the offspring of the Moguls. They are, indeed, frequent- 
ly called by the name of Moguls to this day, and they are often confounded with the Moguls and Chigatyes, who still reside in the neighbourhood of Heraut. They themselves acknowledge their affinity to those tribes, as well as to the Calmuks now settled in Caubul, and they intermarry with both of those nations. They do not, howêver, understand the language of the Moguls of Heraut.

Aboolfuzl alleges that they are the remains of the army of the Mogul prince Manku Khaun, the grandson of Chingheez; and Bauber testifies that many of the Hazaurehs, spoke the language of the Moguls up to his time; but he occasions some fresh difficulties by speaking of the Toorkomaun Hazaurehs, and by always coupling the Togderrees with the Hazaurehs in the hills, while he asserts the Toorks and Eimauks to have been inhabitants of the plains. * There seems no reason to doubt that the Eimaulss and Hazaurehs are the same people, though separated since their conversion to Mahommedanism by the different sects they have adopted; the Eimauks being rigid Soonees, and the Hazaurehs violent Sheeahs. They are indeed often confounded, notwithstanding this marked distinction, nor will the confusion appear at all unnatural, if it be remembered that they resemble each other in their Tartar features and habits, and in the

* I find it difficult to account for the number of Toorkee words which are met with in the language of those tribes. Why, if they be Moguls, should they have spoken Toorkee; and why, if 'Toorkee was their language, should they have lost it, residing as they do on the borclers of Toorkistaun? Why should they have adopted the Persian tongue, while tlic bulk of their northern neighbours speak Toorkee, and of those on the sunth Pushtoo? 
despotic character of their governments, the points in which they form the strongest contrast to the Afghauns. They differ, however, from each other in so many points, that it will be expedient to treat them separately, and I shall begin with the Eimauls who inhabit the western half of the mountains.

The country of the Eimauks is reckoned less mountainous than that of the Hazaurehs, but even in it the hills present a steep and lofty face towards $\mathrm{He}-$ raut: the roads wind through valleys and over high ridges, and some of the forts are so inaccessible that all visitors are obliged to be drawn up with ropes by the garrison. Still the valleys are cultivated, and produce wheat, barley, and millet; and almonds, pomegranates, and barberries are found wild. The north-west of the country, which is inhabited by the Jumsheedees, is more level and fertile, the hills are sloping and well wooded, the valleys rich and watered by the river Margus or Moorghaub. The south of the Tymunee lands also contains wide and grassy valleys. The whole of the mountains are full of springs.

The Zoorees possess Subzaur or Isfezaur, an extensive plain among mountains covered with pines, situated to the east of the road from Furra to Heraut, and in some measure detached from the other Eimauks.

The word Eimank, though I do not know that it is used in Toorkistaun, is the common term among all Tartars of the north and east for a division or a tribe.* 'The nation which I am now describing, is

* I learn from my friend Sir John Malcolm, that there was a large tribe called Eimauks in Syria, a colony from which established 
correctly called the Chahaur Oeemauk, or four tribes, and was in reality formed into so many divisions, although they have now branched out into a greater number.

The original four Eimauks are the Teimunees, Hazaurehs, * Teimoories, and Zoorees.

The first of these Eimaulks includes two other divisions, the Kipchauks and the Durzyes; and the second includes the Jumsheedees and Feerooz-coohes. The Keryes, who live about Toorbutee Hyderee, south of Meshhed, are also said to be Fimauks, but I fancy incorrectly.

Some of these subordinate divisions are now as numerous as the Eimauks from which they sprung; and all, like the original Eimauks, have separate lands and independent chiefs.

The chiefs inhabit strong castles, sometimes containing spacious palaces, where they maintain little courts of their own, and are attended by splendid retinues. They levy taxes on their tribes, and keep troops in their own pay, and mounted on their own horses. The administration of justice, with the power of life and death, and all the rights of an absolute monarch, are in their hands. They carry on their government in the King's name, but they are never controlled in their management of their own tribes.

The Eimauks live almost entirely in camps, which

itself in Lauristaun, and produced the dynasty of Ataubeks, so celebrated in Persian history.

* These are not to be confounded with the Hazaurehs above-mentioned, who will be herenfter described. 
they call Oard or Orde.* Each of these is governed by a Cudkhooda, who acts under the orders of the Khaun.

Their tents are almost universally of the kind called Khirgah, which is used by the Tartars; but the Teimoorees, one of the Eirnauks, prefer the black tent of the Afghanns. All the Eimaulss keep many sheep, and they rear a small, but active and hardy breed of horses, of which many are exported to foreign countries. The few villages in their country are inhabited by Taujiks.

I have heard that the appearance of the Eimaulss often approaches to that of the Persians, though always distinguished by the peculiar features of the Tartar race. Their head-dress is oftener a cap of black lamb-skin than a turban.

Their food is the same with that of the Afghauns, except that they eat horse-flesh, and that the whole of them make their bread of the flour of an oily sort of nut called Khunjick, mixed with that of wheat.

In all respects not mentioned, they resemble the Afghauns in their manners : but the despotic government makes them in general more quiet and orderly. In their wars, where they are released from this restraint, they show a degree of ferocity never heard of among the Afghauns. I have authentic accounts of their throwing their prisoners from precipices and shooting them to death with arrows ; $\uparrow$ and on an

* This is derived from the Turkish word Oordoo, a camp or army, from which we have formed horde.

+ This greatly resembles the Mogul treatment of prisoner's under their conquerors. 
occasion at which a Zooree with whom I have conversed assisted, they actually drank the warm blood of their victims, and rubbed it over their faces and beards.

The Eimauks have always been dependent on $\mathrm{He}-$ raut, though they were immediately under the subordinate government of Seeahbund.

The greater part of them are still in obedience to the prince at Heraut, to whom they furnish troops when required, and at whose court they either attend in person or keep a near relation.

Two Eimauks, the Teimooree and Hazaureh, however, are now subject to Persia. This was owing to their position, which is west of Heraut, and within the limits overrun by the Persians. Their lands are excluded from the Paropamisan mountains, and consist of sandy tracts interspersed with barren hills. The Teimoorees under Killich Khaun have long possessed their present country. The Hazaurehs, on the contrary, were only lately moved to their present seats by Shauh Mahmood on account of a quarrel between them and the Teimunees. The family of Mahommed Khaun, their chief, held the title of Beglerbegee, from the Kings of Caubul, and he retains it under the Persians. The tribe differs from the other Eimauks in having decidedly the features, dress, and manners of the Uzbeks. They are proud of this resemblance, and their chief carefully keeps up a connection with the court of Bolshaura.

I have mentioned that this Eimauk is not to be confounded with the Hazaurehs who inhabit the eastern part of the Paropamisan mountains; but, although they are now separated, the Eimauks and 
Hazaurehs are certainly of one descent, and probably the latter derive their name from the same source with this tribe.*

The best accounts I possess of the numbers of the Eimauks, excluding those last mentioned, lead me to guess them at four hundred or four hundred and fifty thousand souls. It is needless to say that those accounts are neither full nor exact.

The country of the Hazaurehs is still more rugged than that of the Eimauks. The sterility of the soil and the severity of the climate are equally unfavourable to husbandry; what little grain can be sown in the narrow valleys, and reaped before the conclusion of the short summer, contributes to the support of the slender population; but the flesh of sheep, oxen, and horses, with cheese and other productions of their flocks, are more important articles of their food.

The Hazaurehs live in thatched houses, half sunk in the slopes of the hills. The Plate ( $\mathrm{N}^{0}$ XII. $\dagger$ ) shows the dress of the men, which is distinguished by the rolls of cloth which they twist round their legs like the Uzbeks. The women wear long frocks of woollen stuff, and boots of soft deer-skin, which reach to their knees. Their cap sits close to their head, and a slip of cloth hangs down from it behind as far as their middle. Both men and women have strong Tartar features, but are stouter and plumper than their

* The Tartar army used to be divided into a certain number of Hazaurehs or regiments; and it is possible that some of those bodies, originally left to occupy part of a conquered country, may have given rise to the nation of the Hazaurehs.

+ It is a good likeness of Kereem, a Hazaureh once in my service, but his face was more cheerful and good-lumoured. 
neighbours. The women are often handsome, and, what is surprising in a tribe so nearly savage, they have an ascendancy unexampled in the neighbouring countries. The wife manages the house, takes care of the property, does her share of the honours, and is very much consulted in all her husband's measures. Women are never beaten, and they have no concealment. It is universally agreed that they are by no means remarkable for chastity, but I have heard different accounts of their libertinism. In the northeast, which is the most civilized part of the country, the women would prostitute themselves for money, while their husbands were out of the way; but the men, though not jealous, would probably put a detected adultress to death. In other parts of the country, there prevails a custom called Kooroo Bistamn, by which the husband lends his wife to the embraces of his guests.* At all times, if a husband of that part of the country finds a pair of slippers at his wife's door, he immediately withdraws. Both sexes spend a great deal of their time in sitting in the house round a stove. They are all great singers and players on the guitar, and many of them are poets. Lover's and their mistresses sing verses to each other of their own composing, and men often sit for hours railing at each other in extemporaneous satire.

Their amusements out of cloors are hunting, shooting deer, and racing. They clear a spot of ground for the last-mentioned amusement, and ride bare-

* This is Mogul: one of the laws of the Yasa forbids adultery. The inlrabitants of Caiader applied for and received an exemption on account of their old usage of lending their wives to their guests.

VOL. II. 
backed : the stake is often a great many sheep, oxen, or suits of clothes. They also shoot at marks for similar wagers. They are all good archers and good shots: every man has a matchlock. Their other arms are a Persian sword, a long narrow dagger in a wooden sheath, and sometimes a spear.

The Hazaurehs are very passionate, and exceedingly fickle and capricious. After conciliating one for an hour, a single word may make him fly out and break with you. Setting aside their hot temper's, they are a good people, merry, conversable, goodnatured, and hospitable. Many stories are told of their extreme simplicity. It is enough to mention that they believe the King of Caubul to be as high as the tower of a castle: still, as they are Asiatics, they are not exempt from habits of falsehood. Their irritable disposition involves them in constant broils among themselves.*

The Hazaurehs generally live in villages of from twenty to two hundred houses, though some live in Tartar tents like the Eimauks. Each village is defended by a bigh tower, capable of containing ten or twelve men, and full of loop-holes. $\dagger$

There is a kettle-drum in each, and in time of peace, a single man remains in the tower, to sound an alarm if necessary. I have heard a gathering of the

* The Afghauns tell many stories of the power of fascination posscssed by some of the Hazaurehs, who can eat out the liver of any person on whom thcy fix their eyes. This fable is very common in India and Persia, and is attributed to various tribes. The details of the operation are given with great solemnity in the Ayenee Acberee.

+ This building is cnlled Ottopore, or Ortopore, which I helieve is borrowed from the Turkish. 
Hazaurehs described: one of these drums was beat, and the sound was taken up, and repeated from hill to hill. The Hazaurehs armed in haste, and rushed out, till at last a force of two or three thousand men was assembled at the point of attack.

Each village has a chief called the Hokee, and one or two elders, called by the Toorkish word Auksukaul, (which, like Speen Zheereh in Pushtoo, and Reesh Suffeed in Persia, means literally white beard), but all entirely dependent on the Sooltaun.

The Hazaurehs are divided into tribes, of which the Deh Zengee, Deh Koondee, Jaughooree, and Polaudeh, are among the most considerable, and each has its own Sooltaun, whose power is absolute in his tribe. He administers justice, imposes fines, imprisons, and even puts to death. Some of these Sooltauns have good castles, fine clothes, and servants adorned with gold and silver. They have constant disputes among themselves, so that there is scarcely a Hazaureh tribe which is not at war with its neighbours. They have also foreign wars; and sometimes two or three Sooltauns unite to rebel against the King; but they have never any solid or useful confederacy. I have been told by a man who had been employed to collect the revenue under Zeinaul Khaun, that he had sometimes been called into an assembly of six or seven of these chiefs, who would inform him that they were determined not to pay the tribute, and that he might go about his business. In the same night, one chief would come and declare that he had no share in this contumacy; next morning, one or two more would come, and the whole confederacy would dissolve. When it once came to blows, they would 
often hold well together ; but they were always quelled in the end. This Zeinaul Khaun was a Mogul of the neighbourhood of Heraut, who was made governor of Baumeeaun in Shauh Zemaun's reign, and who dragged up a gun into the strongest parts of the mountains, and reduced the Hazaurehs to a degree of order and obedience never equalled.

In general, the Hazaurehs were divided between the government of Ghorant and Baumeeaun, and at present they are scarcely under any goverument at all. They have wars with the Eimaulss, and also with Killich Ali Khaun, the great Uzbek chief in Bulkh, who has reduced many of the nearest Hazaurehs uncler his authority.

The Hazaurehs are all enthusiastic followers of Ali ; they hold the Afghauns, Eimauks, and Uzbeks in detestation for following the opposite sect, and they insult, if they do not persecute, every Soonnee who enter's their country. They even distrust such of their own countrymen as have been much among: the Afghauns, suspecting them of having been corrupted.*

When this is considered, it is not surprising that there should be no Taujiks settled among the Hazaurehs, and that they should have little trade or intercourse with the rest of mankind. The little trade they have is carried on by barter: sugar and salt are the foreign commodities in most request.

The above account of the Hazaurehs is not without

* Keerem, who is represented in Plate XII. actually was converted, and on his return to the Hazaureh country, he was treated with the utmost contempt; bis own relations called him "a hog," and never addressed him but with " Suggau!" O dog! 
exceptions. Some of them have democratic governments like the Afghauns, particularly the large tribe of Guvvee, which is settled towards Hindoo Coosh, and which, perhaps, differs from the rest in some other particulars. The plains about Mookkoor, Karrabaugh, \&c. to the west of Ghuznee, are inhabited by Hazaurehs, who in their situation, and in every thing but their features, exactly resemble Taujiks.

There are many Hazaurehs in Caubul ; five hundred are in the King's guard, the rest gain their bread by their labour; many of them are nuleteers.

It is difficult to guess the number of the Hazaurehs: their country is considerably more extensive than that of the Eimauks, but it is less productive, and worse peopled; so that I should not suppose they amounted to more than from three hundred to three hundred and fifty thousand souls.

I must not quit the Hazaurehs without noticing the celebrated idols of Baumeeaun, which stand within tlieir country.

I have only lieard two idols described, though it is sometimes said there are more : of these one represents a man, and one a woman. The former is twenty yards high, the latter twelve or fourteen. The man has a turban on his head, and is said to have one hand held up to his mouth, and the other across his breast. The surrounding hills are full of caves, but I have heard of no figures or inscriptions which they contain.

The learned in Indian antiquities are of opinion that these idols are connected with the worship of Boodh, and their situation strongly reminds one of the colossal statues at the entrance of the great tem- 
ple, supposed to belong to the religion of Boodh, in the midst of the city of caves, which is to be seen at Canara in Salsette; but my information on such subjects does not qualify me to form any opinion regarding them.*

[* It is hardly necessary to refer to the description and engraving in Burnes's travels.-1838.] 


\section{CHAPTER III.}

\section{HERAUT.}

Heraut is included within the Dooraunee limits, and ought to have been described with the lands of that tribe ; but as it was always a distinct government, and is now almost an independent state, it seemed more suitable to treat of it separately.

Heraut, formerly called Heri, is one of the most ancient and most renowned of all the cities of the East. It gave its name to an extensive province at the time of the expedition of Alexander, and it was for a long time the capital of the empire, which was transmitted by Tamerlane to his sons. From the house of Timour it passed to the Suffavees (or Sofis) of Persia, from whom it was taken by the Dooraunees in 1715. It was retalien by Naudir Shauh in 1731, and it fell into the hands of Almed Sliauh in 1749, since which time it has been held by the Dooraunees.

The descriptions I have already given of Afghaun cities, leave me little to say of Heraut, which perhaps surpasses them all in magnificence. I must, however, notice the great mosque, a lofty and sprcious building, surmounted by domes and minarets, and ornamented with the shining painted tile which is so much used in all Persian buildings.*

[* It is said to have been built by Sultann Gheians Oodeen of Ghore in the 12th century.-1838.] 
The city is surrounded by a broad ditch, filled with water from springs. It has a high rampart of unburnt brick, the lower part of which is strengthened by the earth of the ditch heaped up against it. On the northern side is the citadel, built on a mound which overlooks the town. It has a rampart of burnt brick, and a wet ditch. Herant covers a great space, and contains about 100,000 inhabitants.* Two-thirds of that number consist of Herautees, or ancient inhabitants of the place, who are all Sheeahs: a tenth of the whole population may be Dooraunees, and the rest all Moguls and Eimauks, with the same mixture of strangers that is found in all the Afghaun cities. The city stands in a fertile plain, which is watered by a river crowded with villages, and covered with fields of corn. This rich landscape receives additional beauty and variety from the mosques, tombs, and other edifices, intermixed with numerous trees and gardens with which it is embellished and from the lofty mountains by which it is surrounded.

The inhabitants of the country round Heraut are, for the most part, Taujiks, and bear the character already attributed to that respectable race. They are all Soonnees. Among the rest of the inhabitants are to be found Afghauns, Eimauks, and Beloches; and many Moguls and Chaghatyes still dwell in the neighbourhood of a city which was so long the seat of their national greatness.

* In the account which I wrote of this city in 1810, I had greatly underrated the number of inhabitants, and have taken the present statement from Captain Christic, whose observations tended to confirm the rest of my account. [At present, the number of inhabitunts does not exceed 45,000. Conolly's Truvels, vol. ii. page 2.-1838.] 
The revenue of Heraut is reckoned at $1,000,000$ rupees, of which more than half is allotted to the payment of troops, or granted to various persons. * The remainder is paid into the local trensury; but the amount never sufficed for the expenses of the province, and a fixed sum used to be remitted from Caubul till the reign of Shauh Zemaun. One great expense was the maintenance of the provincial army. The Gholaums, or troops in constant pay, at one time amounted to eight thousand men; and the coutingents of the Eimauks and some of the Dooraunees completed the force. Almost the whole of Khorassaun was at one time included in this province.

A govermment of such importance was naturally considered as a suitable employment for one of the King's sons. It was held by Timour Shauh in his father's lifetime. It was at a later period conferred on Shauh Mahmood, and is now in the hands of the brother of that monarch, Prince Feerooz Oodeen, who has the usual title of Haujee, from his having made a pilgrimage to Mecen. He loolds a court of his own, composed, in general, of the younger brothers of the Dooraunee and Cuzilbaush nobles of the court of Caubul. His officers of state and all his establishments are on the model of the King's; and as some of the Dooraunee lords, and most of the Eimauk chiefs, reside at Heraut, he is enabled to maintain considerable splendour.

He has the reputation of a mild and respectable, though a timid prince; but it appears from Captain

* [Mr. Conolly estimates the sum now paid in money at 21,4292 . ; but this is only for the city and its vicinity. The general land revemue is paid in grain.-1838.] 
Christie's accounts, which are later and probably more correct than mine, that he has lost much of his popularity by giving himself up to the councils of a Persian minister.*

The Prince at Heraut always exercised an au-. thority almost uncontrolled by the King, and the civil wars in the kingdom have been favourable to the independence of Prince Feerooz. He endeavours to keep as much as possible out of the sphere of these troubles, and I believe he acknowledges the sovereignty of either of the competitors when his power seems well established, but his close connection with Mahmood, who is his full brother, inclines him to that party; and this, together with his fear of Futteh Khoun, has led him more than once to send a force under his son to co-operate with that party.

The siege of Heraut by the Persians is detailed in the history. Feerooz at that time engaged to pay a contribution of 50,000 rupees $(6000 l$.) He may perhaps have promised to renew this payment annually; and I have heard that a sum of money has since been extorted from him by the fear of an approaching army; but the tribute which the Persians represent him to pay seems to be one of the fictions with which that people are so fond of indulging. their national vanity.

* Captain Christie states that this preference of a Persian, or, as he calls him, a Mogul, has occasioned great jeaiousy among the Afghauns; but that the Prince finds the former more adapted to his purposes of extortion than the Afghauns, "who, being accustomed to the free and independent tenure of the land, are not so likely to assist in a system of plunder, for which the Moguls are proverbial." 


\title{
CHAPTER IV.
}

\author{
SEESTAUN.
}

There is no country to which an admirer of Persian poetry and romance will turn with more interest than to Seestaun, and there is none where his expectations will meet with so melancholy a disappointment. Nor is this to be attributed to the exaggeration of the poets, for the numerous ruins which it still contains, testify Seestaun to have been a fertile country, full of cities, which in extent and magnificence are scarcely surpassed by any in Asia: nor are the causes of its decline less apparent than the proofs of its former prosperity.

Except on the north, where it joins the soutlwestern border of the Dooraunee country, the province is surrounded by wide and dismal desarts, whence every wind brings clouds of a light shifting sand, which destroys the fertility of the fields, and gradually overwhelms the villages.* The only parts which still retain their fertility are those on the banks of the Helmund and Furra Rood, and of the lake which is formed by those rivers. This celebrated lake is termed by our geographers the Sea of Durra, or Zereng. In Persian books it is said sometimes,

* The native village of Moollah Jaffer, whom I have so often mentioned, has been deserted since he left Seestaun from this cause. 
to be called the Sea of Loukh, and by the people of the country the Sea of Zoor, or of Khaujeh. In truth, I suspect it has no name at all in the neighbourhood, but is merely called the Lake, or the Sea. I have heard various accounts of its extent: the best make it at least one hundred and fifty miles round, though they differ about its shape. The water, though not salt, is brackish and hardly drinkable. In the centre stands a single hill, which is called the Cohee Zoor, or hill of strength, and sometimes the fort of Roostum : tradition indeed declares it. to have been a fort in ancient times; and as it is steep and lofty, and surrounded by water of great depth, it is still a place of refuge for some of the inhabitants of the opposite shores. The edges of the lake, for a consiclerable breadth, are choked with long rushes and reeds, the shores also are overgrown with the same sort of vegetation; and being liable to inundation, are full of miry places and pools of standing water. These marshes and thickets are frequented by herds of oxen, which are fed by a description of men distinct from the other inhabitants of Seestaun: they are said to be tall and stout, but black and ugly, with long faces and large black eyes: they go almost naked, and live in hovels of reeds. Besides their occupation of herdsmen they fish and fowl on rafts among the rushes of the lake.

The country immediately beyond these woods of reeds produces grass, and grain, and tamarisks, as does the narrow valley through which the Helmund flows, and probably the banks of the Furra Rood. The rest of the country is almost a desart: like all desarts, it yields forage for camels, and here and 
there it affords a well for the wandering Beloches who talie care of those animals.

The original inhabitants of Seestaun are Taujiks, but they have now received some additions fiom other countries. There are said to be two consider. able tribes, called Shehrukee and Surbundee, which have emigrated from Persian Irauk to Seestaun, and in mucl later times a tribe of Beloches has fixed its residence in the east of the country. The Taujilis and the two first-mentioned tribes exactly resemble the Persians, and have little remarkable in their character. The Beloches are now commanded by an enterprising chief, named Khann Jehaun Khaun, who is the terror of caravans, and of all the neighbouring countries. They formerly lived in tents, and subsisted by pasturage and pillage; but they have now applied themselves with industry and success to husbandry, and have adopted the dress and manners of the people of Seestaun.

The nominal chief of all Seestaun is Mullik Behraum Kyaunee, who is descended (or reputed to be descended) from the ancient house of $\mathrm{Ky}$, which reigned long over Persia, produced Cyrus and other great monarchs, and terminated in the death of $\mathrm{Da}$ rius, and the subversion of his empire by the Greeks. Mullik Behraum is very sensible of the glory of so illustrious a descent; he still assumes the title of King, and maintains, on a small scale, the state and forms of royalty; but his authority is only recognized in a small part of Seestaun, and his whole force is under a thousand men. His capital is called Jellallabad.

It now contains a few thousand inhabitants; but the 
ruins which surround it, for a vast extent, bear witness to its former grandeur.

The family have had a short gleam of prosperity at no very remote period. The head of it, Mullik Mahmood, rose into great notice in the beginning of Naudir Shauh's career, and acquired possession of the greater part, if not the whole, of Khorassaun. $\mathrm{He}$ was at last defeated and put to death by Naudir Shauh, who reduced the whole of Seestaun, and who appears to have transferred the government to a brother or a cousin of Mahmood. Solimaun, who was chief in the time of Ahmed Shauh, submitted to the Dooraunees, and gave his daughter to their King. The Kyaunees have since paid a light tribute, and furnished a contingent to the King of Caubul, but it has. sometimes been necessary to enforce the performance of these acts of submission. There was a body of Seestaunees at Peshawer in 1809, cornmanded by Mullik Mahmood, a grandson of the famous prince whose name he bore.

I have not heard what relation Mullits Behraum bears to the present government, except that Prince Caumraun is married to his daughter. The Persians, as usual, pretend that he is. subject to their King. I cannot hazard a conjecture on the population of Seestaun. 


\section{CHAPTER V.}

\section{BELOCHISTAUN AND LOWRR SIND.}

Belochistaun* is bounded on the north by Afghaunistaun and Seestaun, and on the south by the Indian Ocean; it has Upper and Lower Sind on the east, and Persia on the west. It is six hundred miles long, and three hundred and fifty broad. The largest division of it is that which belongs to the Khaun of Kelaut, and comprehends the greater part of Sees. taun, and the whole table-land of Kelaut. The first of these tracts is low and hot; the soil is good, but, from the want of water, the greater part is a

* The close connection between Belochistaun and Caubul appenrs to require a more extended account of the former country, but I trust the geograplyy of that part of Asia is already in better hands. Lieutenant Pottinger and Lieutenant Christie were despatched in 1809, by Sir John Malcolm, to explore the Beloche country and the enst of Persia, tracts at that time wholly unknown to Europeans. They performed this enterprising and important journey with complete success, and joined Sir Joln Mrlcolm at Maraughn, almost on the borders of the Ottoman empire. The hardships, fatigues, and adventures of such an undertaking, may well be imagined, Lieutenant Christie has since fallen, gallantly heading the Persians under his command, in a battle witl the Russians; but I hope the particulars of the interesting journey which he and his associate performed with so much perseverance and courage, will, ere long; be laid beforc the public, by the survivor. 
naked and uncultivated plain. Round Gundawa, Dauder, and other towns, however, is well watered and cultivated, and yields the productions of India. It is mostly inhabited by Juts. The talle-land, on the contrary, is high, cold, rugged, and barren. It affords only the coarser produce of Afghaunistaun.

The people are Brahooee Beloches, mixed with Taujiks, there called Dehwaurs. The former people are like a ruder sort of Afghauns, barbarous and uncivilized, but hospitable, hardy, laborious, and lonest. They are divided into Khails lilie the Afghauns, but the general government has swallowed up the internal institutions of those societies.

All the hilly parts of Belochistaun beloug to the Brahooes; the plains are inhabited by another lace called Rind, of which numbers reside in Secstiun. These two races, though comprehended under the common name of Beloche, are entirely distinct in most respects. Their languages differ entirely from each other, and from all the neighbouring tongues. Neither seems to be connected with the Arabs, as lats been supposed. The last chief, Nusseer Khaun, had subjected all Belochistaun; but the reigning prince, Mahmood Khaun's possessions, are reduced by rebellions to the districts above mentioned, and some trifling ones on the desart at the western foot of the table-land. His revenue is only 300,000 rupees $(30,000 l$.$) , but he maintains ten thousand troops,$ and might, in case of necessity, call out twenty thousand on foot, on horseback, or on dromedaries. $\mathrm{He}$ acknowledges the King of Caubul's sovereignty, pays a quit rent for his dominions, and furnishes eight thousand troops to the royal army, on express 
condition that they are not to be employed in civil wars.

Shawl, with Hurren and Daujil (two districts near Dera Ghauzee Khaun), were granted by Ahmed Shauh to Nasseer Khaun, in reward of his services, and on condition of his permanently supplying one thousand foot to serve in Cashmeer.

I shall say but little of Sind. I made few inquiries respecting that province while in the Caubul dominions, because there was a British mission at its capital; and I have since found that an account will probably be laid before the public by a gentleman* who has had better opportunities of knowing it than I possess.

I have here given the name of Sind, in compliance with former usage, to the tract which I have elsewhere distinguished by the term of Lower Sind. It is bounded on the north by Shekarpoor and Bahawulpoor ; on the east, by the Indian desart; on the west, by the mountains and hills of Belochistann; on the south-east by Cutch, and on the south by the sea. The grand feature of the comntry is the Indus, which divides it into two parts, of which that on the east of the river appears to be the largest.

The resemblance of this country to Egypt, has often been observed. One description might indeed serve for both. A smooth and fertile plain is bounded on one side by mountains, and on the other by a desart. It is divided by a large river which forms a Delta as it approaches the sea, and annually inundates

* Lieutenant Pottinger, to whom I am indebted for some particulars respecting Sind. Some others I owe to a manuscript by Lieu. tenant Maxwell of the Bombay Marine, who accompanied the missious to Siud. 
and enriches the country near its banks. The climate of both is hot and dry, and rain is of rare occurrence in either country.

Even the political circumstances of Sind and Egypt have at present an accidental resemblance: in both a submissive people are tyrannised over by a barbarous tribe, who, in both instances, yield a reluctant submission to a distant monarch.

Egypt, however, divides the sea which washes the richest kingdoms of the East from that which is bordered by the active and wealthy ports of Europe: its own produce is also an object of demand in the latter country; and hence, in spite of all the vices of its government, it still presents populous towns, numerous canals, and plentiful harvests. Sind, which (besides the obvious inferiority of its communications) is placed in the midst of countries destitute of the industry of Europe, and differing little from each other in their produce and wants, is deprived of all the stimulus which commerce can bestow. Hence the rich lands on the river are allowed to waste their fertility in the production of weeds and bushes, while those inland are neglected, and left to their original sterility. The evils of this neglect of agriculture are heightened by the barbarous luxury of the chiefs, who appropriate vast tracts of the land best fitted for tillage to maintain those wild beasts and birds which afford them the pleasures of the chase. Yet there ale some parts of Sind to which these observations do not apply; some places in the neighbourhood of the river, or its branches, are cultivated, and the soil there displays its natural fecundity in bringing forth most of the productions of India ; and the whole dis- 
trict of Chandookee, enclosed between the Indus and a remarkable branch of it, is highly cultivated, and eminently productive. This branch of the Indus runs out to the west, and, after spreading over a wide tract, which at different seasons is either a marsh or a lake, it again joins the main stream seventy miles below the place of its separation.

Sind is a bare country; the few trees it produces are of the kinds common in India. It has no remarkable animals, but the number of camels which are fed in it is worthy of remark. 'They are used to draw water, to turn mills, \&c., but the goods of Sind are much transported by water carriage, nor is that mucl employed, for a few flat-bottomed boats are sufficient for the commerce of this impoverished country.

The capital of Sind is Hyderabad, a large fortified town, situated on a rocky hill. I should conjecture it to contain about eighty thousand inhabitants.

Tatta, the ancient Pattala, which was once a flourishing commercial town, is now greatly declined, but still contains about fifteen thousand inhabitants.

Much of the population of these towns is Hindoo; but the bulk of that of the country, is composed of Mahommedans.*

At the time when Sind fell under the Afghaun dominion, it was governed by a prince of the tribe of Calhora, which I believe belongs to the south of Persia. Abdoolnubbee, the last prince of this race,

* [Sir A. Burnes states the population of Hyderabad to be twenty thousand souls, and that of Tatta fifteen thousand. The whole population of the country, he estimates at a million. - 1838.] 
disgusted all his subjects by his tyranny and bad goverument, and embroiled himself particularly with the Talpoorees, a tribe which formed the principal part of the military population of his country. The chiefs of that tribe at length entered on a conspiracy to depose him; but their practices became known to $\mathrm{Ab}$ doolnubbee, who put them all to death. This act of violence, accompanied, it is said, with treachery, produced an open revolt, and encled in the expulsion of Abdoolnubbee from Sind.

Timour Shauh, after some unavailing attempts to restore him, conferred on him the government of Leia as an indemnity for Sind, and formally invested the chief of the Talpoorees with the government of that province. Abdoolnubbee repaid the Shaul's bounty by rebelling in his new province, was defeated by the royal troops, and ended his days in poverty at Dera Haujie Khaun in Upper Sind. The Talpoorees have remained in possession of Sind ever since his expulsion.

At the time of the last mission to Sind, the government was in the hands of three brothers, who had divided the country into three unequal shares, but who lived in the same house, and transacted all affairs in concert. Meer Gholaum Ali, the eldest of these, in whose hands the chief direction of the state had been placed, has since died, but a new settlement has been effected without any tumult or bloodshed. A small portion of the province still remains in the hands of Meer Tarra, a connection or dependent of the house of Calhora.*

* [It appears from Sir A. Burnes, that these three chiefs are all dead, and the clemise of the last led to a civil war. The three, how- 
The three chiefs of the Talpoorees are called the Meers, or Ameers (commanders), of Sind. They rule in the name of the King of Caubul, and are appointed to their government by his letters patent ; but as they are Sheeahs, and as they owe their government more to their own force than to their prince's favour, they are heartily disaffected to the Dooraunee state. They ought to pay a revenue of 1,500,000 rupees annually to the royal trensury, but since the troubles in the kingdom of Caubul they have generally withheld it, unless when in immediate fear of the royal armies. Shanh Shujah was only able to obtain eight lacs for the revenue of the year before I was at Peshawer; the rest he allowed to be deducted on pretence of bad seasons. Even this sum was not paid till the King reached the frontiers of Sind; but his army, including the Beloches under Mahmood Khaun, did not on that occasion exceed eight thousand men. I imagine that they are more submissive to Shauh Mahmood.

The dress of Sind is a long cotton gown, and a quilted cap of brown cotton clotll, shaped like the crown of a hat, but narrower; they also wear trowsers and a loongee.

The people are generally of the middle size, thin, though not weak, and blacker than most of the people of India. There is little to praise in their character, which is debased and degraded by the oppres-

ever, only held a portion of Sind, yielding a revenue of fifteen lacs of rupees: there were two chiefs nearly independent of them, of whom one had ten lacs of rupees revenue, and the other five. This would make the whole revenue of Sind only thirty lacs of rupees $(300,000 l)-1838$. 
sion of their government. The only thing that struck me in the Sindees with whom $I$ have conversed, is their deficiency of intelligence. Those who know them well, however, add, that they have all the vices of an enslaved people.

The chiefs appear to be barbarians of the rudest stamp, without any of the barbarous virtues. 


\section{CHAPTER VI.}

UPPER SIND, MOULTAON, LEIA, ETC.

Shimarpoor is bounded by the Indus and the Beloche country on the east and west ; on the north it has the Mozaurees, and Sind, on the south. The province is fertile towards the Indus, but dry and barren at a distance from that river. The town is of considerable size; it is surrounded by a mud wall, but has no ditch. The inhabitants are almost all Hindoos. They are called Shikarpoorees, and speak a particular dialect of Hindostaunee, called by their name. There are many wealtby bankers in the town, and a considerable trade is kept up with the Rajpoot country, Sind, Candahar, and Peshawer. Shikarpooree bankers are to be found in every part of the Dooraunee dominions, and in all the towns of Toorkistaun. There are very few Afghauns (not above two hundred) settled in the town of Shikarpoor. The inhabitants of the country are Jauts, Beloches, and a few Sindees.

The revenue paid to the King is three lacs of rupees. The Haukim keeps up very few troops.

The remarkable fort of Bukkur, situated on an island in the Indus, belongs to this province, but has a separate governor.

The Mozaurees who live to the north of Shikar- 
poor, are a tribe of Beloches, I believe of the Rind division. They inhabit a woody and ill-cultivated country. They live almost in a state of anarchy, and have made themselves notorious for their robberies on the highway, for their piracies on the Indus, and for their predatory incursions into the country of their neighbours.

Dera Ghauzee Khaun lies between the Indus and Belochistaun, to the north of the Mozaurees. It was conquered by Ahmed Shauh. The country, I imagine, resembles the adjoining tract of Muclselwaud already described, but is much better cultivated.

The revenue is less than five lacs of rupees. The province is in complete subjection to the King. The town is nearly as large as Moultaun, but much of it is in ruins. The country suffers much from the frequent change of the governors.

The province of Dera Ismael Khaun is composed of the tract called Muckelwaud. The country and its produce have already been described: its revenues, \&c., will be mentioned under Leia, to which it is at present annexed.

I have mentioned in another place that the northwestern corner of the Indian desart is cut off by the streams of the Punjaub; and that the tract thus formed is fertile within reach of the inundation of the rivers, while the rest is sandy and waste. This explains the character of the provinces of Babawulpoor, Moultaun, and Leia, which are situated on the east of the Indus, and to the south of the Salt range.

The territory of Bahawulpoor extends two hundred and eighty miles from north-east to south-west, 
and a hundred and twenty miles from north-west to south..east, at the broadest points. It includes, for a certain distance, both banks of the Indus, of the Hydaspes, and of the Acesines. The banks of the rivers are every where rich. To the west of the Acesines, the country at a distance from them is poor, but to the east it is absolutely desart. The principal towns are Bahawulpoor, Ahmedpoor, Jullallpoor, Seetpoor, and Ooch. The strongest place is Derawul, a fort that owes its strength to the desart with which it is surrounded. It was the ordinary residence of Bahawul Khaun.

The inhabitants of Bahawulpoor are Jauts, Beloches, and Hindoos. This is the population of the neighbouring provinces also, but Hindoos are most numerous in Bahawulpoor.

Bahawul Khaun was rather a tributary prince than a governor on the part of the King. His ancestors gained their possessions as early as Naudir Shauh's time: Bahawul Khaun himself succeeded when an infant, and had ruled for upwards of forty years. His family, which is called Dawood-pooter, was from Shilarpoor, and was originally in a low station, but now claims descent from Abbass, the uncle of Mahommed. During the life of Bahawul Khaun, the government was mild and well-ordered; and, though he was said to have collected a considerable treasure, his impositions on the people were moderate.

His whole revenue was $1,500,000$ rupees : his army exceeded ten thousand men, including five battalions of match-lock men, who wore a regular dress. He had a foundry for cannon, as had the chiefs of Moultaun and Leia; but Bahawul Khaun's guns were on 
good carriages, while all the others in the kingdom of Caubul are exceedingly ill mounted. He only paid 150,000 rupees annually to the King. Bahawul Khaun has been dead three years, and his son and successor is far from being his equal in prudence and good management. $\mathrm{He}$ is exposed to great uneasiness and danger from the increasing power of his neighbours the Siks.*

The greatest length of the province of Multaun is a hundred and ten miles, and the greatest breadth seventy. The country near the river is rich, but the rest is poor and thinly inhabited : the whole has suffered much from the incursions of the Silks, and many ruined villages are every where to be seen.

The revenue collected is 550,000 rupees, of which 250,000 go to the King.

The force, when I was there, was about two thousand men, and about twenty guns; but ten or twelve thousand militia could be called out on emergency. Nothing could be worse than the government; all sorts of direct exactions were aggravated by monopolies, rapacious and ungovernable troops, and every other kind of abuse.

This province has undergone many changes, which do not seem yet to be at an end. It was taken from the Great Mogul by the Persians, and fell to Ahmed Shauh on the death of Naudir. It was for a short time in the hands of the Marattas immediately before the battle of Pauniput, and was recovered on that victory. The Siks had it for two years at a later period; they have since made several attacks on it,

[* The son of Bahawul Khaun retains his principality, which has been guaranteed to him by the British Government.-1838. I 
and at present are only induced to spare it by the submissions of the Haukim, and by pecuniary payments on his part.

Leia and Dera Ismael Khaun are both under Mahommed Khaun Suddozye.

Leia formerly belonged to the Beloches. I do not know when it was conquered by the Dooraunees.

The banks of the Indus are rich, but the land at a distance from that river is a sandy desart.

Leia is the capital town; but the residence of the Nabob is at Bukhur, a small but flourishing town, near the Indus; or at Maunkaira, a strong fort in the most desart part of the province.

Both provinces only yield five hundred thousand rupees, of which three hundred thousand go to the King. Mahommed Khaun has two battalions of matchlock-men, five thousand good horse, thirty guns, and two howitzers. He is on friendly terms with the Siks, probably because his country towards the frontier is particularly uninviting.

Dauira Deen Punnah is a little district enclosed within the lands of Leia. It yields a revenue of a hundred and fifty thousand rupees, and is granted rent-free to a Dooraunee lord.

Leia is bounded on the north by the salt range, beyond which is a rugged and mountainous country inhabited by small and fierce tribes, of whom the most conspicuous are the Kautirs, an Indian tribe independent both of the King and the Siks.

To the north of those mountains are the fertile plains of Chuch and Hazaureh, inhabited by Indians converted to the Mahommedan religion, and called Goojers. Among them are many turbulent Afghauns 
of various tribes, and these last are the master's of the country.

To the north of these plains is Drumtour (the country of the Jadoons), already described as belonging to a branch of Eusofzyes."

North of it is Turnaul, a poody and mountainous country, which joins on the north to Pukhlee, a country of the same lrind, but much more extensive, inhabited by Swautees, and under a separate governor appointed by the King.

All these countries stretch along the Indus; but our progress to the north is now stopped by snowy mountains.

To the east of Pukhlee are the countries of the Bumbas and Cukkas. The former is under two or three chief's called Rajas, the principal of whom resides at Mozufferabad: both tribes are Mahommedaus. Their countries are composed of vast mountains, difficult passes, and thick forests. They are of importance to the Dooraunees, as forming their only communication with Cashmeer. 


\section{CHAPTER VII.}

\section{CASHMEER.}

The valley of Cashmeer is surrounded by lofty mountains, which divide it from Little Tibet on the north, from Ladauk on the east, from the Punjaub on the south, and from Pukhlee on the west. A branch of the Speen (white) Caufirs approaches Cashmeer on the north-west. There are but seven passes into the province: four are from the south, one from the west, and the remaining two from the north. That of Bember is the best ; but that of Mozufferabad or Baramoolla, lying towards Afghaunistaun, is now most used. I shall not attempt to describe this celebrated valley after Bernier and Foster: the account of the latter in particular, cannot be surpassed.

The Cashmerians are a distinct nation of the Hindoo stock, and differ in language and manners from all their neighbours. The men are remarkably stout, active, and industrious. They are excessively addicted to pleasure, and are notorious all over the East for falsehood and cunning. By far the greater part of the population are Mussulmauns. Aboolfuzl enumerates a succession of upwards of a hundred and fifty Hindoo Kings, who reigned over Cashmeer before the year 742 of the Hejra, when they were supplanted by a Mahommedan dynasty. This last, after 
reigning near three hundred years, was subdued by Hoomauyoon, the son of Bauber. Cashmeer remained in the hands of the Moguls till the time of Ahmed Shauh, when it was taken by the Dooraunees, who have since possessed it.

The Cashmerians seem to have been rebellious when their country was first occupied by the Dooraunees, but they are now completely subdued by the strong measures of the government. No Cashmerians, except soldiers in the service of the state, are allowed to wear arms within the city. The same restriction is not imposed in the country, but the power of the native chiefs is annihilated, and a strong force of Afghauns and Kuzzilbaushes is kept up within the valley, which is sufficient to check any disposition to revolt.

The governor is invested with all the powers of a King, and the administration is very tyrannical. From the small number of passes, the government is enabled to prevent any persons entering or quitting Cashmeer without its permission. Its numerous spies pervade all ranks of society, and the inhabitants are harassed by every kind of oppression: this misgovernment increases the depravity of their character, but their natural gaiety prevents it destroying their happiness.

The city of Cashmeer is the largest in the Dooraunee dominions. It contains from a hundred and fifty to two hundred thousand inhabitants.

The gross revenue of the province is said to be $4,626,300$ rupees, which is nearly equal to $500,000 l$.

The sum due to the King depends on the contract entered into by the governor. When at the highest, 
it was 2,200,000 rupees, from which a deduction of 700,000 was allowed for the pay of troops, so that $1,500,000$ was the whole which reached the royal treasury. Upwards of six lacs are assigned in Teools to the neighbouring Rajas, to Afghaun chiefs, and to Moollahs, Dervises, and Hindoo Fakers. The rest is charged to the real or alleged expenses of collection, and to the pay of civil and military establishments.

The governor has constantly at his disposal a force of five thousand four hundred horse, and three thousand two hundred foot.

The Afghauns, who serve in Cashmeer, seem entirely to alter their character, and to become insolent and luxurious. Most of them are pleased with their situation, but still their fondness for their own country prevents the western Afghauns from remaining long in Cashmeer.

The remote position of Cashmeer, and the absolute authority enjoyed by the governors, often induces them to rebel; but notwithstanding the strength of the country, they are always easily subdued. The Cashmerians are of no account as soldiers, and the Afghauns and Kuzzilbaushes are enervated by the life they lead, and probably little disposed to act with vigour against the King; while the royal army is composed of poor adventurous soldiers, who look forward with avidity to the plenty and the pleasures of Cashmeer, and who know the sufferings they must undergo in case of a retreat.

The repulse of Shauh Shujah's troops has been mentioned in another place. Cashmeer has since been reduced by the Vizeer Futteh Khaun, who impru- 
dently and unnecessarily called in the assistance of the Siks in that enterprize. The present governor is a brother of Futteh Khaun.

The most remarkable production of Cashmeer is its shawls, which supply the whole world, and which are said to be manufactured at sixteen thousand looms, each of which gives employment to three men, ${ }^{*}$

* The following is an extract from the report drawn up by Mr. Strachey, who made many inquiries on tlis subject, and who had some shawl stuffs made under Jis own inspection, of wool procured at Umritsir. The manufacturers were pioneers belonging to the embassy, and they worked in a common tont ; yet they appeared to find no difficulty in their employment. "A shop may be occupied with one shawl, provicled it be a remarliably fine one, above a year, while other shops make six or eiglit in the couree of that period. Of the best and most worked kinds, not so much as a quarter of an inch is completed in one day by three people, which is the usual number employed at most of the shops. Shawls containing much work are made in separate pieces at different shops, and it may be observed that it very rarely liappens that the pieces, when completed, correspond in size.

"The shops consist of a frame-work, at which the persons employed sit on a bench: their number is from two to four. On plain shawls two people alone are employed, and a long, narrow, but heavy shuttle is used; those of which the pattern is variegated are worked with wooden needles, there being a separate needle for the thrend of each colour ; for the latter no shuttle is required. The operation of their manufacture is of cisurse slow, proportionate to the quantity of work which their patterns may require.

" The Oostaud, or head worliman, superintends while his journeymen are employed near him immediately under lis directions. If they have any new pattern in hand, or one with which they are not familiar, he describes to them the figures, colours, and threads which they are to use, while he keeps before him the pattern on which they happen to be employed, drawn upon paper.

"During the operation of nuling, the rough side of the shinwl is 
The mountains round Cashmeer are in many places inhabited by tribes who are in a sort of dependence on the Dooraunees. Their chiefs have Teeools within the valley, which have probably been given to ensure

uppermost on the frame, notwithstanding which, the Oostaud never mistalkes the regularity of the most figured patterns.

"The wages of the Oostaud (the employer furnishing materials) are from six to eight pice per day; of the common workmen, from one to four pice (a pice in Cashmeer may be about three lialfpence).

"A merchant, entering largely into the shaw trade, frequently engages a number of shops, which he collects in a spot under his eye; or he supplies the head workmen with thread which has been previously spun by women and afterwards coloured, and they carry on the manufacture at their own houses, having previously received instructions from the merchant respecting the quality of the goods he may require, their colours, patterns, \&c.

"After the goods are completed, the mercliant carries them to the custom-office, where each shawl is stamped, and he pays a certain duty, the amount of which is settled according to the quality and value of the piece. The officer of the government generally fixes the value beyond what the goods are really worth. The duty is at the rate of one-fifth the price.

"Most shawls are exported unwashed, and fresh from the loom. In India, there is no market for unwashed shawls, and at Umritsir they are better washed and packed than in Cashmeer. Of those sent to the westward, many are worn unwashed.

"The wool of which the shawls are made is imported from Tibet and Tartaly, in which countries alone the goat which produces it is said to thrive. That which is brought from Roclauk is reckoned the best. Its price in Cashmeer is from ten to twenty rupees for a turruk (which is supposed to be about twelve pounds): the whitest sort is the dearest.

"It would perhaps be difficult to determine with accuracy the quantity of shawls manufactured annually; supposing, however, that five of all kinds are on an average made at each shop or loom in the course of a ycar, the number would be eighty thousand, which is pror bably not far from the truth."

VOL. 11 . 
their obedience: they furnish some troops to the Haukim, and pay him revenue when he is strong enough to levy it. Their dependence is, however, very slight.

The following are the only chiefs of this description of whom I have any account:-

On the north is a chief, whom the people of Cashmeer call the Raja of Little Tibet (Khoord Tibet), or of Tibet i Zerdauloo and Dauro. He has probably only a part of Little Tibet. Azaud Khaun sent an expedition into that country, but I do not know whether he first reduced it.

I have not leard of any inhabitants in the high mountains between Cashmeer and Ladauk.

The southern mountains contain many principalities, of which the chief seem to be Kishtawaur, Chundunee or Chinaunee, Jummoo, Khussiaul, and Dung Akhoroor, Rajour, and Proanch. The chiefs of these states retain the old Findoo title of Raja, though they and their subjects are mostly Mahommedans. Their countries are thinly peopled, as might be expected from their nature; but for a mountainous tract they are not ill inhabited. The people resemble the Cashmerians in their language and manners, but have a great mixture of those of the countries to the south. 


\section{BOOK V.}

IHE ROYAL GOVERNMENT OF CAUBUL.

\section{CHAPTER I.}

OF THE KING.

IN most Asiatic governments there are no limits to the power of the crown but those of the endurance of the people; and the King's will is never opposed unless by a general insurrection. Among the Afghauns, however, the power of the Dooraunee aristocracy and the organization of the other tribes afford permanent means for the control of the royal authority, and for the peaceable maintenance of the privileges of the nation. But as they have no statute law (except that of Mahommed), and no public records of the proceedings of their government, it is impossible that any regular constitution should have grown up among them. There are, however, some established customs and opinions respecting their government which I shall proceed to state.

The crown is hereditary in that branch of the house of Suddozye which is descended from Ahmed Shauh. There does not, however, appear to be any rule fixed for its descending to the eldest son. When a King dies it has been usual for the great Dooraunee 
Sirdars present at the court to meet and consider which of his sons is to succeed. They are determined by the will of the father, and by the age and cliaracter of each of the princes; and their voice secures the possession of the capital, and gives a great advantage to the prince in whose favour it declares; but the practice of conferring the different great governments on the King's sons generally leads to a contest, which is decicled by the wealth, abilities, and popularity of the rivals.

The whole of the royal family, except those whom the King particularly favours, are imprisoned in the upper citadel of Caubul, where they are well treated, but closely confined. Those who remain at large are appointed to the government of provinces or the command of armies, where the ostensible authority of a Suddozye is required to secure the obedience of the great, and to sanction capital punishments; they are, however, in general, entirely under the control of a deputy of the King's appointing.

'The King's title is Shauhee Doorree Doorraun, but it is only used in treaties and other public instruments. In general, he is merely styled Shauh or Padshaul (the King), and the common people often call him by his name, Mahmood, or Shujah, without any addition at all. The court is called the Derree Kauneh, which, like Durbar in India, and Aulee Kaupee (Sublime Porte) in Turkey, signifies the gate, a form of oriental adulation which implies that a sub. ject ought to intrude no further into the palace, even in his thoughts.

The King has the exclusive privilege of coining, and his name is put on all the money in the empire. 
It is well known what consequence the Asiatics attach to this right, and that they regard the possession of it as the chief test of sovereignty. A similar test is the privilege enjoyed by the King of being prayed for in the Khootbeh (part of the Mahommedan religious service).

He has the right of war and peace, and can make treaties of his own authority. Notwithstanding the example of Shawl,* it seems to be understood that he cannot cede any part of the territory occupied by Afghaun tribes.

All appointments are in his gift, but in many cases his choice is confined to particular families; of this description are the chiefships of tribes. Some offices of the state, and many even of the King's houseliold, are also hereditary.

He has the entire control of the revenue, both in. collection and expenditure. He cannot, however, increase the settlement of the land revenue, fixed by Ahmed Shauh, which is very light. The only means he possesses of increasing his resources, derived from the Afghauns, are fines, compositions for military service, and, in some cases, arbitrary valuations of the produce, on which the revenue is assessed.

These expedients are not very productive, and the use of them, in cases where the government could easily enforce a new assessment, seems a clear acknowledgment that the prerogative is limited in this respect.

The King cannot resume the grants of his predecessors. In civil wars, the grants of one pretender are resumed by the other, on the ground of their not

* Part of the country of the Caukers, which was granted by Ah. med Shauh to the prince of Belochistaun. 
being the acts of a lawful monarch ; but even this is not often done.

The customs have never been altered. I do not know whether the King has the right to increase them; he certainly has the power, as his doing so would not immediately affect any body of men strong enough to question his orders.

The King has the control of military levies, and the command of the army.

A part of the administration of justice has been shown to be left to the internal government of the tribes; the other branches belong to the sovereign, who appoints all Cauzees, and confirms their sentences in places where they have criminal jurisdiction. In cases where the crime is against the state, the King is the sole judge. His power, however, does not, even in this case, extend to the life of a Suddozye (the King's tribe). Timour Shauh put the grand vizeer to death, and the measure was never blamed; Shauh Mahmood's execution of Meer Allum Khaun (the head of the Noorzyes), was condemned for its injustice, not for its illegality : but the execution of Wuffadar Khaun Suddozye and his brothers, by the same prince, is still universally reprobated, as contrary to the fundamental laws of the state.

The King has the direction of religious affairs, but the national religion being firmly established, he has little room for interference. The rights which the Afghaun nation possess over the conquered provinces and other dependencies of the state, are entirely vested in the crown.

Besides the direct powers thus possessed by the King, it is obvious lie must derive much influence from the exercise of them. 
In the policy of the Court of Caubul towards its own subjects, the most striking object is the close connection of the King with the Dooraunees, and rivalry between him and the aristocracy of that tribe. It is the King's policy to keep the Dooraunees in subjection to himself, while he exalts them over the other Afghauns.

For this purpose, he protects the Taujilss, and all others whose power he can use to depress the nobles, without endangering the ascendancy of his tribe. His policy towards the Dooraunee lords, the 'Taujiks, and the Afghaun tribes respectively, resembles that of a King of Scotland towards the barons, the burgesses, and the clans of the Highlands.

The King's object with the Afghaun tribes is, to get men from the western, and money from the eastern; with the provinces also, the practice of the government has been to exact little from those in the west, and use them for defence alone; but to avail itself of the resources of the eastern provinces, and of the means they afforded for further extension of territory.

In like manner in foreign policy the Afghauns have shown no desire for western conquest. Their views towards Persia and Toorkistaun, were confined to the defence of Khorassaun and Bulkh. It was, indeed, a death-bed injunction of Ahmed Shauh to his sons not to attack the Uzbeks, whom he called a hive without honey.

Another wise precept is attributed to him, which was to forbear attacking the Siks till their zeal had subsided, and their manners softened. In fact, the Siks have become attached to agriculture, and have 
entirely lost their aptitude for the protracted and desultory warfare which enabled them to withstand the power of Ahmed Shauh.

The Afghaun government has always shown a good deal of moderation towards its own subjects, its dependent states, and even its enemies. It is mild in punishments, and its lenity is more conspicuous, from a comparison with the severity of the Persians. It is not uncommon for a great rebellion to terminate without a single execution; and when there are punishments for rebellions, they always fall on the chiefs alone. The Persian practice of blinding or maiming the common people is unknown. During the time the embassy was at Peshawer, there was but one execution; it was that of a Sheeah Dervise, who was tried on the accusation of the Moollahs, and found guilty of blasphemy.

The Afghaun government, however, like most others in the East, is disgraced by the perfidious means sometimes resorted to by its ministers to seize offenders, and by the use of torture. A temptation to the former practice may be found in the ease with which a criminal can elude the pursuit of government in a country so full of fastnesses, and where it is a point of honour to assist a fugitive. The use of torture was learned from the Persians: it has long existed, but it is only under Mahmood that it is commonly practised. It is chiefly made use of to extort money, and, consequently, falls oftenest on the rich and great.

The government endeavours to maintain quiet and prosperity among all the Afghaun tribes; but, aware of their having interests distinct from its own, it does 
not watch over their welfare with that solicitude which one would expect from a King towards his own nation. The provinces are generally governed with tolerable mildness and equity, in some cases from the weakness, and in others from the wisdom of the government. The eastern provinces suffer most from the rapacity of the government and its agents; seldom from jealousy or wanton insolence. Cashmeer alone suffers every sort of tyranny.

The Afghaun government has little information about neighbouring states. 'Though its attention was long directed to India, and though its merchants frequently visit that country, the greatest ignorance of its state still subsists. The ministers know that the Mogul empire has declined; but have a very imperfect knowledge of the numerous states that have been erected on its ruins. They are rather better acquainted with Persia and Tartary, but even there they trust to the reports of merchants and travellers. They have no news-writers (as in India.) Embassies are rare, and never permanent.

Twelve years of civil war have, in a great degree, altered the government even from what is described above. The King is now more than ever dependent on the Dooraunee lords, and is in consequence deprived of all choice in the appointment of his ministers, and nearly of all control over them in the exercise of their powers.

The armies of the state being engaged in wars among themselves, many of the tribes and provinces have become rebellious or refractory, and many of the sources of revenue are therefore cut off. Of what could still be realized, great part has been 
given in Teeools to the principal nobility; what remains is almost entirely consumed by the embezzlements of governors and ministers, which the King can no longer correct, lest his strictness should deprive him of his adherents.

As the King cannot compel the tribes to send the contingents of men which they are bound to furnish, his army is composed of soldiers who come for pay, or from attachment to their leaders. The failure of the revenue naturally diminishes this species of army; and the troops who do serve are more at the disposal of their commanders than at the King's.

As these resources, such as they are, are often divided between two competitor's, it is easy to conceive low the power and influence of the crown must lave sunk. 


\section{CHAPTER II.}

ADMINISTRATION OF THE GOVERNMENT.

THE general administration of the government is conducted by the King, with the assistance of the Vizeer Auzim (Grand Vizeer).

This officer has the entire direction of the revenue, and the management of the political affairs of the government at home and abroad. He has also the control of all the other departments.

The vizeer ought to be appointed from the clan of Baumizye, and from the family of Shauh Wullee Khaun; but this rule was departed from by Shauh Zemaun, who made a Suddozye* vizeer; and by Mahmood, who has bestowed that office on Futtel Khaun Baurikzye.

* The following remark of Sir John Malcolm on this subject, is illustrative of the Afghaun notion of giovernment.

"The appointment of Rehmut Ullah Kuaun, commonly called Wuffadar Khaun, was spoken of with great disapprobation when I was in Persia in 1800 . It was considered as a departure from all usage; and the grouncls of objections were, "that though it was proper the King should be a Suddozye, and have his person held sacred, from belonging to that venerated tribe, his vizeer ought not to be of the same tribe, as if he also was safe from attack, no one would be responsible for the acts of cruelty and oppression that might be committed :' others deemed the King impolitic in appointing a Suddozye to be his vizeer, as such an officer might aspire to the crown, on the ground of being one of that tribe." 
These innovations give great disgust, and used generally to be avoided, by allowing the office to remain in the hands of the leereditary claimants, but transferring the greater part of the powers to some officer more in the King's confidence; an expedient which occasions much confusion, and renders it almost impossible to know exactly the duty or powers of any officer of government.

Next to the vizeer in the general administration, the principal ministers are the Moonshee Baushee (or chief secretary), who manages all the King's correspondence; and the Hircarrah Baushee, who is at the head of the intelligence department, and who has the command of all the Chuppers and Cossids (mounted and foot messengers). Under this head may also be considered the Nusuirchee Baushee, whose duty it is to superintend ail punishments, and who is besides a kind of earl marischal, and the Zubt Begee, who seizes on all property ordered to be confiscated or sequestrated.

The heads of the revenue and judicial departments, and the chiefs of the army; are among the greatest officers of state; but their functions will be more conveniently mentioned when the branches of the administration with which they are connected, are explained.

The officers of the court and household are very numerous. Their establishment is formed exactly on the model of Naudir Shauh's. Each of the branches belonging to it is distinguished by a particular dress. The appearance of the court is very regular and decorous, and riust have been magni- 
ficent before the civil wars, and the plunder of the furniture and decorations of the palaces.

The principal heads of these departments are the following: the Meer-Akhor, or master of the horse, whose employment is hereditary in the head family of the Ishakzyes.

The office of Ishikaghaussee Baushee is a considerable one, hereditary in a great family of Populzyes. The meaning of the word in Turkish is doorkeeper, but the duty is that of master of ceremonies.

The station of Arzbegee is hereditary in the family of Akram Khaun. The duty is to repeat in an audible voice to the King any thing that is said by his subjects who are admitted to his presence. It is intended to correct the mistakes which people unaccustomed to the court might make in the language of ceremony, and also to avoid the inconveniences arising from the great distance at which strangers are kept from the person of the King. The office is important, as the King often desires the Arzbegee to inquire into representations made through him, and is guided in the decision by his report.

The Jaurchee Baushee and Jaurchees are criers attached to the Arzbegee.

The Chaous Baushee presents persons admitted to pay their respects to the King, dismisses the court, and communicates the King's orders on such occasions, according to set forms in the Toorkee language.

There are many other officers who are at the head of establishments maintained for purposes of state, but none of any weight in the court. 
The offices of Surdookdar Baushee (keeper of the wardrobe, or keeper of the jewels), of Hukeem Baushee (chief physician), and the heads of different departments of the household (as the hunting and hawking establishments, the kitchen, the camel and mule establishments, \&c.), do not merit much notice, though some of them are filled by people of consequence.

The Peeshkhedmuts deserve, however, to be mentioned; for though they are menial servants about the King's person, they are often men of rank, and frequently of great influence with their master.

The Eunuchs have also a good deal of weight, from their being admitted to the King's presence at all times, and being allowed to be present at the most secret deliberations.

The expenses of the household are defrayed by particular funds allotted for that purpose, and managed by a particular establishment, of which the King's private treasurer and the Mooshrif or auditor of accounts are the heads. 


\section{CHAPTER III.}

OF THE DIVISION OF THE IRINGDOM INTO PROVINCES.

Tне whole kingdom is divided into twenty-seven provinces or districts, exclusive of Belochistaun, the chief of which country is, except in name, rather a party in an unequal alliance than a subject.

The eighteen most important are each governed by a Haukim, who collects the revenue and commands the militia ; and a Sirdar, who commands the regular troops, and whose duty it is to preserve the public tranquillity, and to enforce the autlority of the Haukim and Cauzy; when the Haukim is a Dooraunee, he usually holds the office of Sirdar also.

The administration of civil justice is conducted by the Cauzy.

Under the Haukim and Sirdar, the revenue and police are administered by the heads of tribes; and under them, by the heads of the subdivisions of their tribes.

The importance of the heads of tribes is greater or less in proportion to the degree of subjection in which the country is held: where the tribes are powerful, every thing is done through the heads; where they are weak, as at Peshawer, the Haukim and Sirdar send their orders direct to the heads of subdivisions; and in Cashmeer, among the Taujiks, and in the provinces on the Indus, where there are 
many Hindukees, the Haulkims or Sirclars send theip officers to individuals, or employ the heads of villages as their instruments.

The eighteen provinces where Haukims reside, are Heraut, Furrah, Candahar, Ghuznee, Caubul, Baumeeaun, and Ghorebund, Jellallabad, Lughmaun, Peshawer, Dera Ismael Khaun, Dera Ghauzi Khaun, Shikarpoor, Sewee, Sind, Cashmeer, Chuch Hazaureh, Leia, and Moultaun.

In all these places the Haukins are removable at pleasure, except when they contract for the revenue, in which case they ought to be left till the end of the year.

They are still removed in all but Sind (where the King always selected the Haukim from a particular family, and where, since 1790, he has lost all internal control); Moultaun and Leia (where the King bas not been able to remove the governor since Shaul Mahmood's accession); and Heraut, which has been kept by Prince Ferooz since Mahmood's expulsion.

The other nine divisions are generally composed of countries belonging to Afghaun tribes. There is a Dooraunee governor appointed to each, who is called Sirdar. He never resides in his government; but, once a year, goes himself or sends a deputy, with or without a force (according to the necessity of using intimidation), to collect the revenue. At other times the regulation of the country is left to the heads of tribes, subject to some control in extraordinary cases from the Sirdar. The Sirdar, in most cases, recommends the member of the head family whom he thinks fittest for the chiefship of each tribe under him. There are Cauzees appointed by the 
King in these divisions; but their authority, if supported at all, is enforced by the head of the tribe.

The governments of this last description are the following: the Ghiljies, which includes the Afghaun parts of Lughmaun and Jellallabad; the Saufees and Tagou; Bungushaut, including the Jaujees and Torees; Damaun, including the Murwuts, \&c. up to Bunnoo and Dour; Kuddel Chwhaunsoor and Kishkee Gundoomee, on the borders of Seestaun : Ghoraut (the Hazaurehs); Seeahbund (the Eimauks); Izfezar, or Subzewar, near Furrah; Anaurderreh and Pooshtee Col.

The Sirdars are removable at pleasure, but it seems usual to keep their offices in particular families.

These divisions, as including more unsettled parts of the country, have fallen off from the royal authority, in a greater proportion than those under the Haukims. 
The whole revenue of the Caubul government, in settled times. may be reckoned at something near three crores* of rupees; but of this upwards of a crore is remitted to different half-subdued princes, who are content to hold their revenue as a grant of the King's, but who would never have consented to give it up to him. This description of revenue cannot be considered among the King of Caubul's resources.

The real revenue falls a good deal within two crores.

Of this a great part (about half) is assigned in Teeool (Jageer), most of it was granted on condition of military service, and the benefit which the King: derives from it, will appear in the account of his army ; the rest is allotted to maintain the Moollahs or religious officers, or given in charity to dervises and Syuds.

The remaining sum was received by the King till the breaking out of the present troubles. By the best accounts, it amounted to upwards of nine millions of rupees.

The principal source of the King's income is the * A crore of rupees is about a million of pounds sterling. 
land revenue, which is assessed on the produce according to fixed proportions, which vary with the nature of the land, and are different in different provinces. Some of the Afghaun tribes, and of the remoter provinces, are not subject to this mode of assessment, but pay a fixed sum annually. The other sources of the revenue are the town duties and customs, the produce of the royal demesne, the produce of fines and forfeitures, the profits of the mint, and perhaps some other trifling receipts.

The provisions supplied to the King's household and part of his army by the people through whose country he passes, even when they are not subject to the payment of revenue, must also be reckoned among the resources of the state.

Besides the above, another less fixed branch of revenue is created by accepting of the commutations in money for the troops which ought to be furnished by particular districts and tribes. Fines were at all times levied from Haukims on their appointment to profitable districts, and in these unsettled times an unavowed profit is derived from the sale of offices.

The land revenue is collected by the head man of each village, and paid in some cases through the head of his tribe, and in others directly to the Haukim or his agents. The Haukim generally farms the revenue of his province from government, and lets out that of the districts under him. Once a year he gives in his accounts, which pass through several officers before they receive the King's approbation. The expenses of management, the assignments that have been given on the province, the price of articles 
commissioned by the King, and similar charges, are struck off, and the balance is either sent to the treasury, or more frequently orders, equal to its amount, are given to the troops, and others who have claims on government.

Both in the course of the collections and of the payments, when they are made in this last manner, great peculation is practised by the Haukim.

The smaller provinces, under military Sirdars, are not farmed.

The King's principal expenses are the payment of the army, the household, the court establishment, and the clergy.

The expenses of the army are small in comparison to its strength, from the number of Tecools appropriated to maintain it.

The expenses of the household are, in some measure, lightened by the payments in grain, sheep, and cattle appropriated to that branch.

The pay of the great civil officers is small. They are in a great measure maintained by bribes and perquisites, which, although they have the most pernicious effect on the resources of the state, do not diminish the revenue actually brought to account.

The Moollahs are paid by Teeools, or receive orders on Haukims or money from the treasury : the expense is said to be considerable.

The whole expense of the King of Caubul, exclusive of that defrayed by Teeools, \&c., was not much above half a crore of rupees in quiet years; and what remained of the revenue used to be kept as a fund for extraordinary expenses.

The treasures of the crown have long since been 
dissipated, and the only wealth the King possesses consists in a very valuable collection of jewels, which, although greatly diminished since Timour Shauh's reign, has in some measure been preserved by the difficulty of finding purchasers, to whom parts of it might have been transferred during the distresses of the government. 


\section{CHAPTER V.}

JUSTICE AND POLICE OF THE KINGDOM.

Justrce is administered in cities by the Cauzy, the Mooftees, the Ameeni Mehkemeh, and the Darogha of the Adawlut.

In civil suits the Cauzy receives complaints, and sends a summons by an officer of his own to the defendant. The cause is tried according to the rules and forms prescribed by the Shirra, or Mahommedan law, modified by certain acknowledged parts of the Pooshtoonwullee, or customary law. In doubtful cases the Mooftees give their law opinion, supported by quotations from books of authority.

The Cauzy's orders are never disobeyed, it being reckoned impious to refuse to conform to the Shirra. If lie should be resisted, it is the duty of the Sircar to enforce his decree.

The Ameeni Mehkeneh receives charge of deposits.

The Darogha i Adawlut is supervisor over the whole, and his duty is to see that all proceedings are conformable to law.

In criminal complaints the rules are nearly the same, but the practice is different. Criminals are generally first brought to the Sirdar, and the Cauzy's sentence in all important cases is executed by him : 
JUSTICE AND POLICE OF THE KINGDOM. 263

this gives the Sirdar a degree of power which is particularly felt when he disagrees with the Cauzy.

Where the King happens to reside criminal complaints are made to him. In trifling matters he refers them to the Cauzy, or desires the Arzbegee (the officer through whom representations are made to him) to settle them: serious complaints are always referred to the Cauzy, and the King orders the sentence to be executed, after a formal protestation that the guilt of it, if unjust, is. on the head of the judge.

There are Cauzees in all considerable towns in the Caubul dominions, and they have deputies over the whole country, except that of the three or four tribes who are reckoned to be in open rebellion.

The Cauzees nowhere interpose unless an application is made to them: this happens more rarely in the more remote parts of the country, where they are chiefly appealed to in civil cases. When a crime is not acknowledged by the accused, it is always referred to the Cauzy, but acknowledged crimes are most frequently decided on by Jirgas, in the manner already described.

The usefulness of the Cauzees' courts is in a great measure destroyed by the corruption which prevails in them; and in towns and their neighbourhood, justice is further impeded by the power and influence of the great.

The Cauzees are appointed by the King, at the recommendation of the Imaun of the household.

A few only have salaries from the treasury. There is, however, in some places, if not in all, a small tax imposed on every family in the district, which 
264 JUSTICE AND FOLICE OF THE IRINGDOM.

goes entirely to the Cauzy. They have also fees on marriages, on affixing their seals to deeds, and perhaps on the causes they decide.

The Mooftees have a fee on every opinion they give, but this cannot by itself be enough to maintain them.

The police of towns is managed under the Sirdar by the Meershub, the Molitesib, and the Darogha of the Bazars.

The Meershub answers to the Cutwal in India. He has watchmen under him, called Kishikchees, who are posted on different guards in the town. In Peshawer, and probably in other towns, there are many other watchmen, paid by the people of the ward which they guard. The Meershub goes the rounds at night, and takes up thieves, disturbers of the peace, and offenders against morals. Both the Meershubs and the Mohtesibs are odious and discreditable offices, and they are probably the source of much oppression. In Peshawer, at least, the Meershub paid an annual sum for his office, and extorted fees from gaminghouses, wine-shops, persons whom he took up on suspicion, and from the few houses of ill-fame that are tolerated there.

The Mohtesib inflicts the punishments prescribed by the Mussulmaun law on persons who drink wine, or are guilty of similar irregularities : in Peshawer he does the duty of the Darogha of the Bazars. There are Mohtesibs who go circuits twice or thrice a year in the country, and inspect the conduct of the inhabitants. 'The Mohtesibs in towns have pay, and are entitled to a small tax on shops. Those in the 
JUSTLCE AND POLICE OF THE KINGDOM. 265

country levy their annual fees when on the circuits. The Molitesib is always a Moollah.

The Darogha of the Bazars fixes prices, and superintends weights and measures : under him there is a head of each trade, called Cudkhoodah, or Reeshsufeed, who is also employed in levying the taxes.

In the King's palaces and in camps, there is a Cauzy Asker, or Judge of the army, and Mobtesib of the army, who do the same duties as those in towns.

In the country, the people to whom the land belongs are answerable for the police. In cases of robbery and theft, if the chief of the village, or of the division of a tribe, in whose lands the crime was committed, fail to produce the thief, he pays the value of the property stolen, and levies it on the people under him.

In dangerous roads that are much frequented, there are parties stationed to protect travellers; these are provided by the Khaun of the tribe in whose lands the road lies, but are paid by the King.

The police is, after all, very bad. In many parts of the kingdom travellers enjoy security by engaging an escort of the tribe, or by paying customs to its chief; but the King can do little to protect them, except by sending troops to ravage the land of notoriously predatory tribes, and to bring in the chiefs. The police does not interfere in murders for retaliation, except in towns and their vicinity. 


\section{CHAPTER VI.}

THE MILITARY ESTABLISHMENT.

The established army consists of Dooraunees, Gholaumi Shauhs, and Karra Nokur ; there is also a sort of militia called Eeljauree, which is called out on extraordinary occasions; and volunteers are entertained in actual war under the denomination of Dawatullub.

The Dooraunee clans are obliged to furnish nearly twelve thousand men, as the condition on which they hold their Teeools, or rent-free lands, granted them by Ahmed Shauh and Naudir. In addition to those, they receive three months' pay in the year, when on actual service. This is a sum equal to $10 l$. which, with their lands, is reckoned to make their whole pay equal to $40 l$. per annum.

'They are called out by the King's order, issued to the chief of each clan, and by him notified to the Khauns under him. They assemble the men due by their several subdivisions, and bring them to the place appointed for the rendezvous of the army, where they are mustered and registered before the King.

The men of each clan form a separate corps, called Dusteh, subdivided and commanded according to descent, as in the civil arrangement of the clan. The greater part of the Dooraunees only attend the King during military operations. In wars carried on near 
the Dooraunee country, the King could raise as many Dooraunees as he could pay.

The establishment of the Gholaum Khauneh, or corps of Gholaumi Shauhs, is upwards of thirteen thousand men.

It was first formed by Ahmed Shauh, of the different foreigners whom he found established in the Dooraunee country, and of the troops of Naudir's army and other Persians who attached themselves to the Dooraunee government.

He afterwards recruited them from the Taujiks of Caubul and the districts round it. An arrangement has since been made with the chiefs round Caubul and Peshawer, for supplying men from their tribes for this corps, and receiving payment by assignments of land.

The Kuzzilbaushes, who form about a third of the Gholaum Khauneh, are the best part of the whole. Though they have been so long settled in Caubul, and have engaged in trades, they still retain their original character of military adventurers ; being good troops on service, but more thoughtless and debauched than even their countrymen in Persia.

They are more faithful than the Afghauns in civil wars, knowing that they may at some time be in the power of any prince they offend; and that one party will be less exasperated by their fidelity to its adversaries, than the other would be at their perfidy in deserting it.

The Gholaums suffer more hardship than any troops in the army. They enlist for perpetual service, and they have no means of obtaining redress of grievances, or even of securing their regular payment. 
If he could pay them regularly, the King could probably raise double the number from the Taujiks round Caubul.

The Gholaums are divided into Dustehs, commanded by officers named Kooler Aghaussees. These officers are commonly dependents of the King's, and frequently Peshkhedmuts (personal attendants) and Eunuchs.

The number of Dustehs is generally from eight to ten : their strength is various.

The permanent troops, besides the Gholaums, are the Shaheenchees, men mounted on camels which carry large swivels. They are reckoned at seven or eight hundred.

The King of Caubul is said to have many guns, but Shauh Shujah -had only five when he took the field at Peshawer in 1809 . They were much worse in all respects than any $I$ have ever seen among the native armies of India.

The King has a guard of a few hundred Hindostaunee Sepoys, which mounts at the gate of the Haram. They are dressed in imitation of our Sepoys, but seem to have no discipline.

The irregular infantry, who garrison forts, are paid from the revenue of the province they are situated in. There were only one hundred and fifty at most in the fort of Attock.

The troops kept up by governors of provinces have been mentioned (where it could be ascertained) in the account of the provinces. They can seldom be employed, except in wars carried on in the province of its neighbourhood.

- The Karra Nokur are furnished in time of war 
by the owners of land, at a rate fixed in former times. The expense of this service was provided for by a remission of revenue at the first settlement. The numbers vary; the courtiers pretend that a man is due for each plough, and the tribes near Caubul perhaps furnish the number due on that principle : the more powerful or more remote tribes supply a much smaller proportion, and some none at all. The Taujiks furnish a greater proportion than the Afghauns. On the whole, the number furnished is less than that either of the Dooraunees or Gholaums.

They are formed into Dustehs, and commanded by Dooraunee Sirdars, probably by those who have the government of their tribes. Each division has, besides, a subordinate chief of its own tribe. When they are ordered out, the Mulliks call upon the owners of land to furnish their proportion, and they have their choice to serve or pay for a substitute. The sum to be paid for a substitute depends on the expected duration of the service, and generally is from five to seven tomauns (from $10 l$. to $14 l$.) ; from this the head of the village entertains a horseman, generally at three tomauns; and there is no difficulty in procuring a person to serve from among the poorer people in the village or its neighbourhood.

The Dooraunee chief often takes the money instead of insisting on receiving the horseman, and by this means the real strength of the Karra Nokur is generally under what it is rated at.

Besides this, the King not unusually receives payment in money, instead of the number of Karra Nokur required from a particular tribe or district.

The men who go on service are obliged to remain 
with the army till they are regularly clismissed, without any allowance from the King, or any further advance from the head of their village. Each division is, however, obliged to give an allowance of grain to the families of the horsemen furnished by it. Since the decline of the monarchy, the King may have been obliged, by the want of power, to compel the Karra Nokur to serve, to make them some allowance while on service; but that is no part of the constitution of this body of men.

Except a corps not exceeding two thousand, which is due from the Cohistaun of Caubul, the Karra Nokur are all horse.

The Eeljauree are a militia raised on extraordinary occasions. It seems to be understood that the number to be furnished, ought to be equal to a tenth of the population, but that number probably never has been raised; and, on the other hand, it is admitted that the King may call out a still greater proportion, if he thinks it necessary. The persons who serve in the Eeljauree, are of the poorest classes. They receive a sum calculated to support them during the time for which their services are likely to be required; it seldom exceeds five rupees. This money is paid by the head of each village, and the expense is defrayed by a tax on all the inhabitants of the village, (including Humsauyehs, or tradesmen,) who do not possess land, Moollahs, and other persons exempt from other taxes. I have heard that the owners of land who pay revenue, are not obliged to contribute to the Eeljauree; and, as the Karra Nolkur are raised entirely at the expense of this description of men, the fact of their exemption seems very probable. 
From the smallness of their pay, it is found difficult to get volunteers for this service, and compulsion is almost always resorted to. For this reason, it is only among the tribes about great towns, or on the roads made use of by armies, that the Eeljauree can be raised. As in most cases they cannot be kept long together, or carried to any distance from their own neighbourhood, the King makes little use of this force. The Haukims of provinces frequently assemble the Eeljauree, which, indeed, is in general the only description of troops they have to depend on. The Eeljauree of Peshawer has, however, been several times called out by the King, particularly on all expeditions against Cashmeer. That of Caubul has also been called out on military service.

The numbers of the Eeljauree of these two provinces seem to be nearly equal, and have been of different amount from four to six thousand each, according to the state of circumstances. They seem liable to be employed on public works, as well as on military service ; those of Caubul, for instance, were once assembled by Timour Shauh to clear a canal near the city.

The Eeljauree are almost all infantry. They receive no pay whatever from the King, unless they should be kept above three months in the field.

Dawatullub are only raised for particular expeditions. They receive five tomauns (10l.) when they enlist, which is sufficient pay for one campaign, and they run the chance of the army's remaining longer in the field, in the hope of providing for themselves by plunder. This description of troops are always most numerous in expeditions to India. On such 
occasions people even go without pay, in hopes of plunder.

In foreign invasions, use might be made of the general rising of the people, called in the Afghaun country Ooloossee. This sort of army has been described in speaking of the tribes. Only those of the tribes nearest the scene of action could be expected to rise; they would be under no regulation on the King's part, and no good could be expected, in regular actions, from so ungovernable a multitude; but if properly applied, this kind of force would not be without its advantages. Important risings have often taken place for public objects, not immediately connected with the tribes which rose. Thus, in the Sheeall and Soonnee fray in Caubul, all the neighbouring tribes, especially the Cohistaunees, came to the aid of their religion.

Oooloosee troops get no pay.

The chief officers of the army are called Sirdars. They have always been few. In Shauh Shujah's time there were only three. This permanent military rank must be distinguished from the office of Sirdar in each province.

There is sometimes an officer called Sirdaree Sirdaraun, who takes rank of all the Sirdars, and commands every army where he is present. Shaub Mahmood has conferred this office on Futteh Khaun.

The Shaheenchee Baushee, or commander of the camel artillery, is a considerable officer, He must be a Baurikzye.

Almost the whole of the regular troops are cavalry. The horses belong to the men. Except about five hundred Peshlkhedmuts (personal servants of the 
King's), there is not one man mounted on a horse belonging to government. The chiefs have each some Peshlkhedmuts, mounted on horses belonging to them, and equipped at their expense. These are the best mounted and armed of the whole army. They are generally Kuzzilbaushes.

The horses are mostly from Uzbek Tartary, and the Toorlzomaun country along the Oxus. They are generally small, hardy, and active, well used to the mountainous country in which they are employed, and capable of making very long marches.

The arms of the Dooraunees are a Persian sword and a matchlock; a few of the best men have spears, which they put in the rest when they charge, not having the skilful use of this weapon, which is common in India. A few among them have fire-locks. The chiefs have generally pistols, as have a few of the common men. Shields were formerly in use among them, but are now discontinued.**

* 'The following description of their troops is by Lientenant Macartney, who was himself a cavalry offecr. He is spealking of the Populzyes.

"Their arms and dress are the same as the other Dooraunees, swords, daggers, battle-axes, short matchlocks, and some with locks (firelocks) not longer thari a carabine, but with a larger bore, and some of them have bayonets to fix on them. They also carry long horse pistols, but few of them carry spears. They generally cn'ry their arms under their chogha, or great cloak. Their dress is a pyrahun, or long shirt, over it a kuba, generally made of silk or chintz, with a kummer bund of shawl or loongee, and over all is a chogha, or great cloak, which hangs loose over their shoulders and reaches nearly to the ankle. Their head-dress is generally a shawl or loongee put on in the form of a turban over a cap. They wear boots of the Hussar form, made of deer-skin. They are generally cavah'y, and are mounted on small horses, seldom exceeding fourteen or fourteen

VOS. II. 


\section{The Dooraunees never serve as infantry.}

The Gholaums are armed much in the same way, but have more firelocks and spears.

The Ghiljies use the same arms as the Dooraunees, with the addition of a small shield.

The eastern Afghauns wear Hindostaunee swords, shields, leather cuirasses, matchlocks, and often spears: the use of the last-mentioned weapon is, however, declining.

Each horseman carries provisions, consisting of bread and croot (a sort of hard cheese), and a large leathern bottle of water.

hands and an inch high, but remarkalsly hardy and active, and perform some wonderful long marches; but as they are in the habit of turnirg: their horses loose into the cultivation wherever they go, they lave not much trouble after reaching their ground. They use snaffie bridles. Their saddles are of wood, very light, and the seat is covered with velvet, stuffed with cotton. They have a lhogeer (a sort of pad) made generally of nummud (felt) under the saddle; some of the chiefs have very expensive ones. They appear far superior to the horsemen of Hindoostaun, but have not so good management of their horses, and miglit not be equal to them single-handed; but they must charge with much greater velocity, their horses not being cluecked by martingales or bits, and consequently they would have the advantage in a body. They appear to understand charging in line, and go with grent speed. I never saw them charge in double hine, but the troops which met the embassy as an escort, marched in divisions, and kept their regular wheeling distance. I did not see them wheel into line, but they increased and diminished their front, and also formed line to the front, and kept their files close and regular; but there is no discipline kept up anong them. This party of course were picked mon and horses, and must have received particular instructions to march in regular order with the embassy, but in general they appear just as irregular as the armies of Hincloostaun. They are small men, but stont and active. I lave seen them go at speed over rugged rocky mountains, where if the horse happened to make a false step they would probably be dashed to pieces." 
The infantry have generally a sword, a shield, and a matchlock with a rest. Those of the Cohistan of Caubul, who are reckoned the best they have, carry a firelock, a pistol, and a short dagger, but no sword: the Ghiljies near Caubul, the Khyberees, and some other tribes, use a sort of knife about three feet long, instead of a sword.

On a march, the men of each party generally keep together, but on the whole they move with very little order, though there are many officers whose duty it is to enforce regularity. They have few camp followers compared to an Indian army, and what they have are mostly mounted. The custom of carrying about women and children on service is not practised among them. They have light tents and little baggage, carried on horses, mules, and camels. A smali bazar accompanies the army.

The government appears rarely to take any trouble about providing grain, or making preparations of any sort for their armies; and as the habits of the soldier's adapt themselves to this system, they have less difficulty about supplies than more regular troups.

The usual marches for armies are from twelve to sixteen miles.

The government sometimes gives grain to the troops, and on very particular occasions it sometimes distributes money to purchase provision. In their eastern possessions, the inhabitants of which have something of the submissive character of the Indians, the Afghaun troops seize on grain, forage, firewood, and every thing - else they want, without paying for any thing; and since the confusion in the government these irregularities have seldom or never been 
punished; but in the whole of the country west of the Khyber pass, they are obliged to pay for every article they require.

When their army is in an enemy's country, they send light detachments to make incursions (which they call by the Turkish name Chepawul or Chepow) either against particular places which they endeavour to surprise, or to plunder the open country.

They are long detained by sieges, at which, as might be supposed, they are very unskilful, and which are prolonged by the nature of their armies and the badness of their artillery. When they come to a general engagement, their plan is to make a furious charge, sword in hand, on the success of which depends the fate of the battle. The Persians appear always to oppose the fire of infantry to this charge, and frequently with success : this was the case in all Naudir's battles, and in the recent one at Heraut.

The conduct of the Dooraunees in their civil wars, gives a very mean idea of their military character. Their armies are very small, seldom exceeding ten thousand men on a side, and these are generally illpaid and disobedient. The victory is decided by some chief's going over to the enemy; on which the greater part of the army either follows his example or takes to flight. Even when the battle is decided by the sword, there is little bloodshed, and that is chiefly among the great Khauns, who are interested in the result, the common soldiers showing much indifference to the issue. 


\section{CHAPTER VII.}

THE RELIGIOUS ESTABLISHMENT.

The following are the appointments held by Moollahs, besides the law officers mentioned in the section on Justice and Police.

The Moollah Baushee, who selects the Moollahs proper to be summoned to the Mujlisse Ulima, and is the channel of communication between the Moollahs and the King.

The King's Imaum or Peeshnumauz, who reads prayers to the King.

The Imaum Paurikaub, who attends the King on journeys or other occasions, when his ordinary Imaum may be absent.

The above belong to the royal household. The following compose the establishment of the great towns.

The Shekhool Islam: copies of all patents for stipends and pensions in money to Moollahs are deposited with him, he receives the amount ordered in each from the Haukim, and pays it to the Moollahs to whom it is due.

The Sudder of the city. He keeps a register of all church lands, whether granted by the King or left by private persons, and assigns them according to their original destination under the King's direction.

The Imaum of the King's mosque reads prayers 
there on Fridays, and on the two great festivals called the Eeds.

The second Imaum of the King's mosque reads the Mussulmaun service on every day but those above mentioned.

The Moollahi Khuteeb : his office is to read prayers at the Eedgah without the city on the Eeds.

The Mooderris, or professor of the King's mosque, a Moollah selected for his learning to instruct students at the royal mosque.

There was till lately a great office of Meer Waez, or head preacher; but it bas been discontinued since the rebellion of the last incumbent, the famous Syud Ahmed Meer Waez.

Besides the above are the Imaums of the mosques in towns and in the country.

The Imaums of towns have fees on marriages, burials, and some other ceremonies, and are maintained by them and the gifts of their congregation.

In the country the Imaums have grants of land from the head man of the tribe, or from the tribe itself, and also receive a tax on the principle of tithes, but by no means amounting to a tithe of the produce on which it is levied: all the other Moollahs, who were first inentioned, have salaries from the King, and some have fees besides.

Many Moollahs who do not hold offices have pensions from the King, or lands assigned them by the crown, or by the charity of individuals. Lands are also left to mosques, and are managed by the Imaums belonging to them.

Students at the King's mosque have a daily allowance from his Majesty. 


\section{A P PENDIX.}

\section{APPENDIX A.}

HISTORY OF THE KINGDOM OF CAUBUL FROM THE FOUNDATION OF THE DOORAUNEE MONARCHY.

LITTLE is known of the early history of the Dooraunees. By the best accounts* I can obtain, they appear to have been entirely independent till the beginning of the seventeenth century, when, being hard pressed by the Uzbeks, they agreed to pay tribute to Persia, as the price of protection. They perhaps remained on this footing till 1708 , when the Ghiljies, who had been sulject to Persia, rose against the Georgian Prince Bagrathion, who was governor of Canclahar on the part of the last of the Sophies. At that time the Dooraunees seem mostly to have been settled in the mountains near Ileraut, under the name of Abdaullees, and to have been already long engnged in hostilities with the Ghiljies.

In the year 1716 the Abdaullees, under Abdoollah Khaun Suddozye, invaded the Persian territory, defeated the governor of Heraut in the field, and took that city and many places in its neighbourhood. They were afterwards defeated in a battle with Mahmood Ghiljie; but as that prince soon after conquered Persia, and as his dynasty was occupied during the short period of its dominion in settling its conquests, and in wars with the Grand Signior, the Abdaullees remained for a long time unmolested. Not long after their

* Those of [Aanway, who, from the excellence of his history of the Afgham conquests, is entitled to attention when speaking of the more obscurc period which preceded those events. 
defeat, Abdoollalı was deposed, and perhaps puisoned, by Zemaun Khann, (the son of Dowlut Khaum, and father of Ahmed Slaum,) who took the lead among the Abdaullees, defeated a Persian army of doulble his number, and successfully resisted all attempts of that nation on Heraut. So rapid incled was the increase of the power of the Aldaullecs, that in the year 1722 they were able to besiege Meshhed, nearly in the north-western extremity of Khorassaun.

A series of revolutions afterwards took place, during which the Abclaullees, whose government was at all times democratic, were left for some time entirely without a leader, their affairs being mannged most probably by a Jirga, or council of lieads of families. At last, in 1728, tley were for the first time attacked by Naudir Shaul, and, after a short campaign of various success, were reduced to sulmit to the conqueror.

They rebelled again under Zoolfikaur Khann, (the son of Zemaun Khaun, and elder brother of Ahmed, who had alternately been in exile, and at the head of the Abdaullees during the troubles aloove mentioned. They invaded the Persian territory, and defeated Ibrahim (Naudir Shauh's brother) in a pitched battle. They were besieging Meshhed when Naudir moved against them in person, and drove them back into their own territory. He opened the siege of Heraut in the beginning of 1731, and took it after a most obstinate and active resistance of ten months, in wlich the Abdaullees received some assistance from the Ghiljies. He banished the leading Suddozyes to Moultaun, and compelled a large force of Abdaullees to join his army.

The city of Heraut never rebelled again, but the Abdaullees in the country kept up the war for some time longer, in conjunction with the Ghiljies and Eimauks.

In the course of the next six years Naudir reduced the Ghiljies and took Candahar. Zoolfikaur Khaun and his brother Ahmed Shaul were prisoners in that city. They were released by Naudir, and sent into Mazenderaun in command of a force of their own tribe. The Abdaullees having in the mean time distinguished themselves in lis service (particu- 
larly against the Porte), he rewarded them with the lands they now hold in Teeool, removing them from the west of Heraut to their present territory. He appens from this time to have shown great attachment to the Afghauns. To this partiality, among other causes, is attributed his murder by the Persians in June 1747. On the day which succeeded that event, a battle took place between the Afghauns and Uzbeks under A hmed Shauh on one side and the Persians on the other. It is uncertain who began the attack, nor does the event appear to have decided any thing.*

After this affair Ahmed Shauh fought his way through the greater part of Khorassaun, and passing the fortified places without attacking them, repaired to Candahar, where he arrived with a force not exceeding two or three thousand horse.

He there found that a treasure coming from India for Naudir bad just been seized by the Dooramees, and he immediately claimed it for himself: some of the chiefs at first hesitated to give it up to him, though his authority as head of the Suddozyes was now backed by military force. He put some of the most obstinate to death, and met with no further opposition in his tribe.

In October 1747 he was crowned at Candahar: Dooraunee, Kuzijlbaush, Beloche, and Hazaureh chiefs are mentioned as assisting at the coronation. Ahmed Shaul was then very young: a contemporary historian makes him only twentythree years of age.

He spent the winter in Candahar, settling the country he had already acquired, and arranging his army for future expeditions. In framing his government he appear's to have had the model of that of Persia before his eyes. The forms of his court, the great officers of state, the arrangement of the army, and the pretensions of the crown, were exactly the same as those of Naudir Shauh; but the difference in the situations of the two monarchs was apparent in the manner

* As far as this I have generally followed Sir Willium Jones's turslition of the Nuulir Naumel. 
in which Ahmed Shauh was obliged to modify Naudir's plan, both in the administration of his internal government and in the order of his measures for advancing his power at home and abroad.

The Persians had long been accustomed to entire submission to a despotic government, and had always been attached to their sovereigns. The dynasty which had long ruled them was overtulned by the Afghauns, and in the beginning of Naudir's career Persia was groaning under a foreign yoke: Naudir took on himself the character of the deliverer of his country and the restorer of its native Kings: he connected himself by marriage with the royal family; and when he had sufficiently secured the affections of the army and the respect of the people, lie confined the lawful King, and transferred his authority to himself.

Succeding to an established monarchy, he met with no serious opposition in Persia, and was enabled from the moment of his accession to emplay the whole force of the kingdom in foreign conquests.

Ahmed Shauh, on the contrary, had to found a monarchy over a warlike and independent people, by no means attached to that form of government; those most accustomed to be governed by a King had only felt his power in the means which were used to compel them to pay tribute to a foreign state, and had ever regarded him as a powerful enemy rather than a magistrate by whom they were protected, and to whom they owed loyalty and attachment. They had never been united under a native King, and, from the love of equality so conspicuous in their character, they were likely to view the exaltation of one of their own nation with even nore jealousy than the tyranny of a foreign master.

This difference of the situation in which Ahmed Shauh was placed from that of Naudir made a corresponding variation in his policy. His first object was to secure the affections of his own tribe, on whom he depended for permanent support, as well as for immediate assistance. For this purpose he confirmed the Dooraunees in the possession of thair lands, requiring no sacrifice from them but the attendance 
of their contingent of troops as fixed by Naudir. He distributed all the great offices of his new state among the leading Dooraunees, and established those offices in particular families in the same manner in which he fixed the crown on his own; he left the hereditary chiefs in possession of their privileges, and seldom interfered in the internal government of their clans, except in such a degree as was necessary to keep up his army and to preserve the general tranquillity, which he always effectunily maintained. $\mathrm{He}$ took pains to improve the advantage he derived from the respect of the Donraunees for the Suddozyes: although he probably regarded many of that family with jealousy, as his rivals in the attachment of his tribe, he always maintained their privileges, and enforced the exercise of the respect which was due to them. Stories are told of his severely punishing injuries to Suddozyes, even when offered in supporting his own cause.

With the other tribes, except the Ghiljies, his plan was to. endeavour to form a spirit of attachment to their native King, which he might hope to accomplish by delivering them from foreign dominion, and by a moderate and gradual introcluction of his own power.

His moderation towards the Afghauns may, however, have been caused in part by other motives, as he either felt, or pretended to feel, a strong attachment to his nation, and often gave as his reason for not attacking refractory tribes, that he was unwilling to bring any calamity tupon his countrymen.

For the consolidation of his power at home he relied, in a great measure, on the effects of his foreign wars. If these were successful, his victories would raise his reputation, and his conquests would supply him with the means of maintaining an army, and of attaching the Afghaun chiefs by favours and rewards : the hopes of plunder would induce many tribes to join him, whom he could not ensily have compelled to submit: by carrying the great men with his army he would be able to prevent their increasing, or even preserving their influence in their tribes; and the habits of military obedi- 
ence would prepare them for a cheerful submission to his government at home: the troops also, having the King continually before their eyes, and witnessing the submission of their hereditary chiefs, would learn to regard him as the head of the nation ; and he might hope, as the event proved, that his popular manners, and the courage, activity, vigilance, and other military virtues which he possessed, would impress all ranks with respect, and strongly attach his soldiers to his person.

The state of the Afghaun nation and of the surrounding kingdoms, was favourable to the execution of this plan, as promising security to his own dominions, however ill organised, and offering every chance of success in his attacks on his neighbours.

The Dooraunees had acquired experience and discipline by their long and active warfare with the Persians, and afterwards by the employment of a large body of them under Naudir; and the preference shown them by that great commander, had raised their spirit and confidence; so that they, with reason, consiclered themselves as the best troops in Asia. Their enemies, the Ghiljies, on the other hand, had been broken and dispirited by a long course of defeat and disaster. The remaining Afghauns had learned, by the events of the period which had just closed, to despise the Indians, and to hate the Persians; and were therefore more likely, than at any former period, to favour the establishment of a King of their own nation.

The state of foreign powers was equally favourable. The weakness of the Indian and Uzbek empires had been exposed and increased by their contests with Naudir. The Beloches had also suffered from Naudir, and probably retained a sufficient dread of the Persians to be well disposed to submit to a moderate subjection to their old allies, the Afghauns, rather than expose themselves to the severe government and rigid exactions of their other neighbours. Nusseer Khaun (the brother of Mohubbet the Beloche chief) had been a hostage with Naudir, and appenrs to have fallen into the lancls of Almed Shauh. The Eimaulss and Hazaurehs had 
never been formidable, and their vicinity to the capital and to the country of the Dooraunees, prevented all apprehension of their endeavouring to assert their indejendence.

The fate of Persia was as yet unsettled, but the clissensions which had broken out in Naudir's family, promised to disqualify that empire from molesting its neighbours; and subsequent experience slowed, that the chiefs of western Khorassaun took no great concern in the success of the Persians, but were ready to submit to the power which was most able to distress or to protect them, and which was likely to use its ascendancy with the greatest moderation.

Such was the state of affairs when Ahmed began his conquests. He marched from Candahar in the spring of 1748 , with twelve thousand men, composed of Dooraunees, Beloches, and others. He soon reduced the Gliljies, and appointed Dooraunee governors over them, on the footing on which they now stand. The governor whom Naudir had left in Ghuznee, fled on Ahmed's approach; but Nausser Khaun, who was governor of Caubul and Peshawer, declared for the Great Mogul. He was, however, driven out of Caubul after a feeble resistance, and was already pressed by the Afghaun tribes of Peshawer, when Ahmed's advanced guards arrived, and forced him to cross the Indus.

Ahmed, with undiminished celerity, swam the Indus, and expelled him from Attock and Chuch; after which he proceeded with an army, increased by the Afghauns of Peshawer, to the invasion of Hindoostaun. The governor of Lahore, aware of his intention, called for succours from Dehli ; but Ahmed gave no time for preparation. He advanced rapidly through the Punjaub, defeated the Indian troops in sight of Lahore, and entering that city in triumph, prepared to advance upon Dehli. In the mean time Mahommed Shauh, the Emperor of Hindoostaun, had sent off a powerful army, under his son and his vizeer, Cummeroodeen Khaun, to oppose the invaders. This army advanced to the Sutledge, and took post in such a manner as to cover the usual fords. Ahmed, informed of their position, sucldenly advanced, crossed the Sutledge at a point higher up 
the river, and leaving the Indians in his rear, hastened to Sirhind (where they had deposited their baggage and stores), and captured it before the eneiny could nove to its assistance.

The prince and vizeer of Hindoostaun immediately marched to Sirhind, to attack Ahmed Shauh; but losing courage as they approached, they gave up their resolution, and took post in the neighbourhood of that city. Ahmed Shauh attacked them; and in the course of a cannonade which lasted several days, the vizeer was killed, and the actual command of the army devolved on his son, Meer Munnoo, who conducted himself with so much skill, that the Dooraunees were obliged in their turn to stand on the defensive, and finally to retreat with precipitation during the night.

Soon after this, when the Indian army had set off on its return to Dehli, Mohammed Shauh died, and his son, who had commanded at Sirhind, succeeded him : Sufdur Jung was made vizeer, and Meer Munnoo left in the government of the Punjaub, while the new King continued his march to his capital.

As soon as this intelligence reached Ahmed Shath, he countermanded the retreat of his army, and marched with his usual expedition against Lahore. Meer Munnoo, finding himself opposed to the Dooraunee army, without the prospect of immediate assistance from Dehli, and being, perhaps, disgusted with the preference shown by his new sovereign to Sufdur Jung, submitted to Almed, and consented to hold the government of the Punjaub in his name, and to pay lim the regular tribute of that province.

The affairs of the Punjaul being thus satisfactorily arranged, Ahmerl marched back to Candahar. On his way he settled the governments of Dera Ghauzee Khaun, Dera Ismael Khaun, Shikarpoor, and Moultaun. It was probabiy at this time also, that the southern. Afghaun tribes acknowledged Ahmed for King. The winter of this busy year must have nearly expired before Ahmed reached Candahar.

In the spring of 1749, Ahmed Shauh assembled an nruy 
of twenty-five thousand men from the western part of his dominions. He first marched against Heraut, which surrendered within a fortnight after it was attacked. He then advanced towards Meshhed, reducing all the places on his route.

Shauh Rokh Mirza, the son of Nandir Shauh, was then in possession of Meshhed. He came out to meet Ahmed Shauh, who received him with respect, and left him in possession of his city and territory.

From Meshled he marched against Neeshapoor, and de-. tached Shauh Pusund Khaun Ishaukzye against Muzeenaun and Subzwaur. Ne:shapoor held out olsstinately, and while Ahmed was besieging it, he received intelligence of the failure of his attack on Muzeenaun, and of the defeat of his detachment. Being now apprehensive of an attack from without, he resolved to make a desperate attempt on Neeshapoor. He accordingly directed it to be assaulted by escalade, and was beat off with great loss. Before he had recovered this disaster, a strong force assembled by somc other Khauns of Khorassaun came to the relief of Neeshapoor, and, while he was engaged with them, a vigorous sally was made from the place. The result was very unfavournble to him, and he was compelled to retreat immediately to Meshhed, from whence he retired to H eraut.

In the spring of 1750, Ahmed again marched agaiust Neeshapoor, which he now succeeded in taking. It was probably on this occasion that he reduced the most remote of those parts of Khorassaun that were permanently attached to his dominions.

The Dooraunee empire, I believe, never extended much beyond Neeshapoor on the west. Almed returned from this expeclition to Heraut.

In the course of the winter, or early in the next year, 1751, Alhmed Shauh, was recalled to Meshhed by a rebellion of Meer Allum. Khaun, Chief of Kauin, who had seized on the treasure at Meshbed, and blinded and dethroned Shauh Rokh Meerza. Ahmed Shauh restored Shaul Rokh, and soon after took Kauin, and put Meer Allum to deatli. At this 
time he also made an attempt on $\Lambda$ sterabad, which was repelled by the Kudjirs.

In the summer of 1752, Ahmed Shauh marched into the Punjaub, and reduced Meer Munnoo, who had revolted in his absence. During the same campaign, he conquered Cashmeer, and obtained by negotiation a cession of the country, as far east as Sirhind, from the Great Mogul.

After this, Ahmed returned to Candahar, and ajpears to liave spent the four next years in tranquillity: his nephew Lokmaun Khaun, however, rebelled; and the Ghiljies attempted an insurrection during that period, but both were easily quelled.

He probably employed this interval of leisure in settling Afghaunistaun, and the countries in its immediate neighbourhood.

In 1756, Meer Munnoo, the governor of the Punjaub, died. His death was followed by intrigues and rebellions, and the whole province fell into extreme confusion. This state of things induced the court of Delli to send a large force under the Vizeer Ghauzoodeen into the Punjaub, for the purpose of annexing it to the Mogul dominions. The vizeer succeeded without difficulty, and gave the government to Adeena Beg, who had been deputy to Shauh Nuwauz Khaun, and afterwards to Meer Munnoo, and who was distinguished for his activity and spirit of intrigue. This clone, tlie vizeer returned to Dehli.

Ahmed Shauh, on hearing of this aggression, left Candahar, crossed the Indus, drove Adeena out of the Punjaul, and marched straight to Dehli. The tyranny of the vizeer, and the reluctance with which the Emperor submitted to his control, had thrown that capital into great confusion; and after a faint effort to oppose Ahmed in the field, the Emperor submitterl, and the Afghauns entered Dehli, which suffered sererely from the rapacity of the conqueror and the licence of his troops. After remaining for some time at Delli, Ahmed Shauh sent Sirdar Jehan Khaun against the Jauts. The Sirdar took Bullumgur, and then, advancing by a rapid march on Muttrn, surprised the place during a 
Hindoo festival. A promiscuous slaughter took place on the army's entering the town, and many of the Hindons were afterwards seized and carried into slavery. Sirdar Jehan Khaun then advanced against Agra, and was repulsed by the Jauts. The Dooraunees had now passed the whole of the summer in India, and as they were becoming extremely sickly, Ahmed found it necessary to retire to his own dominions. During his stry at Delhi, he and his son Timour Shauh married princesses of the royal family of India. Large portions were given with these ladies, and the Emperor of India was compelled to bestow the Punjaub and Sind on 'Timour Shauh.

Before Ahmed Shauh left Delhi he gave the office of vizeer of India to a brother of Meer Munnoo, and that of generalin-chief to Nujeeb Khaun, the Afghaun chief of Seharunpoor, who had recommended himself to Ahmed by joining him near the Sutledge on his advance against Delhi.

He left Timour Shauh to command the provinces on the east of the Indus, under the guidance of Sirdar Jehan Khaun. Their force consisted of a few Dooraunees and Persian guards, with a body of troops raised in the country. The King wintered at Candahar, and was soon after engaged in settling disturbances which broke out in Persia and Toorkistaun, but of which I can gather no particulars.

He had scarcely left India when Ghauzoodeen Khaun, who had fled to Furruckabad, then in possession of the Mahrattas, returned with an army of that nation to Dehli, and laid siege to the city. After some defence, Nujeeb Khaun. evacuated the place and Jetired to Seharunpoor. Nearly at the same time very serious disturbances commenced in the Punjaub. They were excited by Adeena Beg, who had fled on the Shauh's approach, and who had afterwards instigated the Silss to rebel, and defeated a division of the royal troops at Jalinder. He had also invited the Mahratta army, which had expelled Nujeeb Khaun from Dehli, to assist in recovering the Punjaub; and a force of that nation now advanced to Sirhind, commanded by Ragoba, the father of the present Paishwa. . 
On this, Timour Shaull and Sirdar Jehan Khaun, who were already pressed by the Siks, and distrustful of their Hindostaunee troops, retired to Eminabad. Lahore, which they evacuated, was taken by the Siks.

The Mahrattas soon took Sirhind; and as they continued their march towards the west, Sirdar Jelian Khaun took the resolution of saving the prince and his remaining troops by retiring across the Indus. He effected his retreat in the night unknown to his Hindostaunee troops, and with such precipitation that his own family fell into the hands of the enemy, by whom they were soon after released. The Mahrattas being now unopposed, pushed their conquests heyond the Hydaspes, and sent a detachment which took possession of Moultaun.

Timour Shauh's flight took place in the middle of 1758 , and Ahmed Shauh was preparing to march to India, when he was detained by the rebellion of Nusseer Khaun, chief of the Beloches.

The history of Belochistaun is remarkably obscure before this period, but it appears that Mohubbut Khaun, whom Naudir had fixed in the government,* had died, and was succeeded by his second brother, Haujee Khaun. That chief appears to have disgusted his subjects by his tyranny, and offended Ahmed Shauh by taking part in Lokmaun Khaun's rebellion. It is certain that he was deposed and imprisoned by means of Ahmed Shauh, and that Nusseer Khaun, his brother, succeeded him in the government. It is not known what induced Nusseer Khaun to throw off his dependence on the Dooraunee government; but he declared himself independent in the year 1758 .

The Vizeer Shauh Wullee Khaun was first sent against him, and was defeated at a place in the neighbourhood of Shawl. Ahmed then marched in person to Belochistaun, where he probably arrived in autumn or in the end of summer. He engaged and defeated Nusseer Khaun, and obliged him to withdraw within the walls of Kelaut, to which Ahmed

* See Jones, Histoire de Nadir Chah. Liyre iv. chnp. 6. 
laid siege. It is said that the Dooraunee chiefs were by no means disposed to accomplish the entire subjection of the Beloche prince (in whose country they were always secure of a retreat when exposed to the anger of their own King), and that the vizeer, in particular, maintained a correspondence with Nusseer, and encouraged him to hold out by representing the disposition of the Dooraunee lords, and pointing out the embarrassment which the King would suffer from the advanced season. The siege of Kelaut lasted forty days, during which time the Dooraunee cavalry suffered severely from the scarcity of forage.

The bad aspect of the King's affairs in India added to his own impatience for a speedy conclusion of the war; and Nusseer having made an overture for peace, a negotiation was commenced, and an agreement concluded, which is still the basis of the connection between the King and the Beloches.

When the news of Timour Shauh's retreat had reached the King, he had sent a small army under Nooroodeen Khaun Baumizye across the Indus. By this time Adeena Beg was dead, and the whole of the Punjaub to the east of the $\mathrm{Hy}$ daspes was under the control of the Mahrattas. The Siks, however, who had long been a sect of military fanatics, were beginning to aspire to the possession of territory, and the successors of Adeena Beg kept up some consequence by their nominal connection with the government of Delli, though the Great Mogul had no real authority in the Punjaub. Nooroodeen advanced with ease to the Hydaspes, the tract between that river and the Inclus being at that time held by the Kauters, Guckurs, Jouds, and other original tribes of the country who had embraced the Mahommedan religion, and who were inclined to the Dooraunees; nor did he meet with much opposition on his march to the Acesines, as the main body of the Mahrattas was now withdrawn to Dehli, but he did not judge it prudent to advance farther till the King should arrive.

Ahmed Shauh's arrival was from various canses delayed till the winter of 1759 , when he crossed the Indus and ad- 
vanced to the Acesines by the road of Jummoo. From that river he continued his march through the north of the Punjaub, the Mahrattas retiring as he advanced : he crossed the Jumna, near Seharumpoor, and was joined at that city by Nujeeb Khaun and the Rohilla chiefs.

The Malıratta army, under Datta Patail and Junkojee Sindia, was at that time in his neighbourhood; but it retreated as he advanced, and continual skirmishes took place between the parties till the Mahrattas reached the neighbourhood of Dehli : they then crossed the Jumna, and advanced to Baudlee near Dehli, so as to cover that city.

A severe action took place at Baudlee, in which the Malrattas were totally defeated, and Dattajee killed : a detachment was afterwards sent against Mulhar Row Holkar, who was advancing to support the Mahratta interest in that quarter; and Mullar Row's army was surprised and totally defented. Ahmed Shauh next took Dehli, and forced Ghauzoodeen Khaun, who had lately murdered the Emperor of India, Allumjeer II., to fly to the Jaut country, where Mulhar Row and the remains of the Mahratta arnry had taken refuge. Ahmed Shauh afterwards pursued the conquest of the Dooab, and marched as far as Anoopshehr, where he cantoned for the monsoon, and was joined by the Nawaub Shujah Oodouli, Vizeer of Hindoostaun.

In the course of this season the Mahrattas* exerted themselves to repair their losses, and a powerful army of their nation arrived from the Deccan, commanded by Wisswass Row, the heir apparent of the empire, and Seddaslseo Row, whom the disastrous issue of this campaign has made so famous in India under the name of the Blow. They besieged Dehli; which was surrendered after a spirited defence by a small party of Dooraunees.

* The transactions of the period and the details of the battle of Panniput are given with grent spirit and appearance of accuracy by a conternporary historian, whose narrative anpears in English in the third volume of the Asintic Researches. To that account I beg lenve to refer my renders; but some pussages in it present so lively a picture of the principal actors in these scenes, that $I$ cannot refrain from quoting them in this place. 
The Shauh was at this time cut off by the Jumna from assisting his troops on the right bank of that river. The same cause prevented his relieving Coonjpoora, sixty miles north of Delli, which was taken almost in sight of the Dooraunee army, now advanced to the river; but this misfortune exasperated the Shauh so much that he resolved immediately to cross the river at all hazards, and bring the enemy to action. His passage was effected with some loss; and the Mahrattas, discouraged by the alacrity with which the King sought a battle, retired to Panniput, where they soon after entrenched themselves. With this position, and their vast train of artillery, they were secure from any attack; but the distresses of an army, consisting chiefly of horse, cooped up in an entrenched camp, may be easily concejved, and they were augmented by the activity of the Dooraunees, who were unrenitting in their exertions to cut off all supplies fiom the enemy's cainp. The Mahrattas, however, remained in this state for' three or four months, during which time many partial actions took place, and some indirect overtures of peace were made by them through Shoojalioodowla.

The Dooraunee army also suffered from the want of supplies; but the patience, vigilance and activity of Ahmed Shauh, enabled him to surmount most of the difficulties that he met with; and the confidence which the troops reposed in him, and the temper and moderation with which he treated his Indian allies, prevented any discontent or disaffection in his camp; while the sufferings of the Mahrattas were borne with impatience, as they were universally imputed to the errors of their commander.**

* "From the day of their arriral in their present camp, Ahened Shauh Dooraunee caused a small jed tent to be pitched for him a coss (ubut a wile and a half) in front of his canp, and he came to it every morning before sun-rise; at which time, after performing his morning praycr, he mounted his horse and visited every past of the army, accompanied by lis son 'Tinour Shanh, and forty or fifty horsemen. He nlso reconnoitred the cainp of the enemy, and, in a word, saw every thing with his own eges, riding usually forty or fifty coss every day. After noon he returned to the sinall tent, und sometimes dined there, sometimes at his own tents $i \mathrm{~s}$ the lines; and this was his daily pructice. 
At last a large convoy, which was coming from the south of the Dooab to the Mahrattas, under an escort of ten thousand horse, commanded by Govind Purıdit, was surprised and dispersed between Dehli and Meerut by Attaikhaun Populzye; and another party, which was escorting treasure from Dehli, having fallen into the hands of the Dooraunees, the Mahrattas would no longer submit to a protraction of the war, which was indeed now become impossible.*

They accordingly marched out of their camp to attack the Dooraunees, on the 7th of January 1761. The Dooraunees got under arms, and the battle began a little before day. $†$ The details of this action need not be enlarged on here. The

"At night there was a body of five thousand horse advanced as ner" us conveniently might be towards the enemy's camp, where they remained alt night under arms; oulicr bodies went the rounds of the whole encampment; and Ahmed Shauh used to say to the Hindostannec chiefs, 'Do yon sleep; I will take care that no harm befalls you;' and to say the trulh, his orders were obeyed like destiny, no man during to hesitate or delny one moment in executing them.

"Every day the troops and cannon on bath sides were drawn out, and a distant cannonade, with many skirmishes of horse, took place: towards the evening both parties drew off to their camps. This continued for near three months : during this time there were thee very severe though partinl setions. And thus every day were the two minies employed from morning till nine or ten at night, till at length the Hindostaunee chiefs were out of all patience, and entreated the Shaul to put an end to their fatigues by coming nt once to a decisire action; but his constant answer was, "This is n matter of war with which you are not acquainted. In other affairs do as you please, but leave this to me. Military operations must not be precipitated; you shnl see how I will manage this affair, antl at a proper opportunity will bring it to a successful conclusion."

- "In this last extremity, the Bhor wrote me a short note with his own hand, which he sent by one of his most confdential servants. The words of the note were these :-

" The cup is now full to the brim, and cannot lold another drop. If any thing can be done, do it, or else answer me plainly at once: hereafter there will be no time for writing or speaking." "

+ "The Navab's hurcarrahs brought word, that the Mahrattas vere coning out of their lines, the artillery in front, and the troops following close behind.

"Immediately on hearing this his Excellency went to 1 he Shaul's tent, and desired the eunuclis to awake his Majesty that moinent, as lie had some urgent business with him. 
King's centre composed of the Rolillas, the Dooraunee Dusteh of Populzye, and a division of half the King's guards, was thrown into confusion by the fire of the enemy's guns, charged by their horse, and almost entirely driven off the field, notwithstanding the exertions of the vizeer, who quitted his horse, and declared his resolution to die at his post.**

The reserve was then brought up by the King in person, and the Malirattas repulsed in their turn; at the same time they were taken in flank by the left wing of the Doornunees, and the consequence was their entire defeat and rout. The general, the heir apparent of the Mahratta empire, and almost the whole of the army, perished in the fight or the pursuit. $\dagger$

"The Shauh came out directly, and inquired what news: the Navab roplied that there was no time for explanation, but desired his Majesty to mount his horse, and order the army to get under arms. The Shauh necordingly mounted one of his horses, which were always rendy saddled at the tent door, and, in the dress he then had on, rode half a coss in front of his camp, ordering the troops under arms as be went along.

"He inquired of the Naval from whom be had bis intelligence; and, he mentioning my name, the Shaulı inmedintely despatched one on a post camel to bring me. After I lind made my obeisance, he asked me the particulars of the news. I l'eplied, that the Mahrattas had quitted their lines, and would attack his army as soon as it should be light. Just at this time some Dooraunee horsemen passed by, with their horses loaded with plunder, which they saicl they had taken in the Mahratta camp; and added, thut the Muhrattns wele running away. The Shaul looked at me, and usked we what I said to that? I replied, that a very short time would prove the truth or fulsehood of my leport. While I was speaking, the Malnrattas, having advanced about a coss and a half from their lines, and got their cannon drawn up in a line, all at once gave a general discharge of them.

"Upon hearing this, the Shauh, who was sitting upon his loorse, smoking a Persian culleaun, gave it to his servant, and with great calmuess said to the Navab, " Your servant's news is very true, I see.' He immediately sent for the grand vizeer and Sliauli Pussund Khaun, \&c."

- "The Navab Shoojahoodowlah, whose division was next, could nut see what was going on, on account of the dust, but finding the sound of men and loorses in that quarter suddenly diminish, he sent me to pxamine into the cause. I found the grand viseer in un agony of rage and despair, repronching his men for quitting lim. 'Our country is firr off, my friends,' said he, "whitleer do you fly?" "

+ It is not easy to determine accurately the force of each purty on this 
This battle was fatal to the Malıratta power; they immediately abandoned their designs on the north of Hindoostaun, and many years elapsed before they resumed their enterprize, under a new leader* and with a new system of war.

After the victory of Panniput, the whole of Hindoostaun appeared to be at Ahmed Shauh's mercy. He, however, adhered to the plan he had originally professed, and contented himself with the portion that had formerly been ceded to him, together with the pleasure of bestowing the rest of the country on such of its native chiefs as had assisted him; and this done, he returned in the spring of 1761. to Caubul. $†$

The wisdom of his forbearance was afterwards very apparent; for, far from being able to maintain so remote a dominion, it was with difficulty that he could retain his own province of the Punjaub, where the Silks now became very powerful. The success of this people compelled him to return to India in the beginning of 1762 , when he completely expelled the Silss from the plain country; but in 1763 he was obliged to return to Candahar, and in the course of a few years the country was in greater confusion than ever.

The circumstances of the King's return to Candahar in 1763 are worthy of notice. $\mathrm{He}$ was at Sirhind when the news of an insurrection at Candahar reached him; and, the rivers of the Punjaub being already swollen, he resolved, notwithstanding that it was now the height of summer, to march by the route of the left bank of the Sutledge and the desart to Moultnum, and from thence to Ghuznee. His

occasion. I conjectare Aimed Shauh's force to hive amounted to forty thousand of his own subjects, thirty thonsand Rohilla troops, and ten thousand belonging to the Indian cliefs; he had also seven hundred camel swivels, and a few guns. The Malurattes are generally said to have liad three lumdred thousand men; the only creditable account of their force $I$ have seen, is that in the Asiatic Researches, which makes their cavalry seventy thonsand, and their infantry fifteen thousand. They had not less thisn two hundred guns.

* Mahajee Sindia, whose troops were diseiplined in the European manner.

+ About this time Ahmed Shauh sent an embassy to China, and the envoy on his return wrote an account of his einbassy. I conld not procure a copy of this curious work. 
army, composed of Afghauns, Uzbeks, Beloches, and other natives of cold climates, suffered great hardships during the first part of this march; and he lost an incredible number of men from heat before he arrived at Moultaun; nor were his sufferings then at an end, for the winter had set in when he reached the mountains of Afghaunistaun, and many of his troops perislied from the cold and snow. The rebellion was easily subdued, as was another raised by Dervish Ali, a chief of the Eimauks in the neighbourhood of Heraut; but Ahmed Shauh's health now began to clecline, and a sensible dimirution of his activity is observable from this time forward. His complaint was a cancer in his face; it seems to have first afflicted him severely in 1764, and it continued to do so till his death, which it occasioned. He was, however, compelled to exert himself, in the course of a few years, by the increased power of the Silks, who seem to have become masters of all the open country as far west as the Hydaspes. Almed went in person against them in 1767 , and drove them again into the mountains; but this expedition, the last he made in India, was attended by no permanent benefit: as soon as the Shauh had quitted the country, the Siks appeared in greater force than ever, and before the end of the next year (1768), they crossed the Hydaspes, and took the famous fortress of Rotass from the Dooraunees. The Shauh was about to exert himself to wipe off this disgrace, when his attention was called to a rebellion in Khorassaun, occasioned by Naussir Oollah Meerza, the son of Shauh Rokh Shauh.

The Afghauns state, that all the chiefs in Persia, except Kereem Khaun Zend, were engaged in this war, and their combined force gave battle to Ahmed Shauh's army, under the command of his sor Prince Timour, in the neighbourhood of Meshed. The battle was well contested, and its issue was more than doubtful, when it was restored by the valour of Nusseer Khaun, the chief of the Beloches, and ended in a complete victory : the Persian army took refuge with Shauh Rookh Shauh, who favoured their escape, and admitted them into Meshhed. It is reckoned impious to fire on that sacred city, which contains the tomb of the Imaum Rezza; and 
Ahmed Shauh was, therefore, obliged to employ a blockade to reduce it, which succeeded after several months. Shauh Rokh Shauh gave his daughter to Timour Shauh, and agreed to furnish a contingent of troops to serve with Ahmed Shauh.

During the siege of Meshhed, a detachiment was sent to take Tubluus, which held out against the Dooraunees. It was defended by Ali Murdaun Khaun, an Arab chief of the Zengooee tribe. Tle detachment was under Sirdar Jehan Khaun, and was in part composed of Beloches under Nusseer Khaun. It was completely successful; Ali Murdaum was killed, and Tubbus taken.

After this expedition Ahmed Shauh returned to Candahar, where his healtl continued to decline, and prevented his engaging in any foreign expedition. In the spring of 1773 , he left Candahar for the hills of Toba in the Atchikzye country, where the summer is cooler than at Candahar. Here his malady increased, and in the beginning of June $177^{5}$, he died at Murgha, in the fiftieth year of his age.

The character of Ahmed Shauh appears to have been admirably suited to the situation in which he was placed. His enterprise and decision enabled him to profit by the confusion that followed the death of Naudir, and the prudence and moderation which he acquired from his dealings with his own nation, were no less necessary to govern a warlike and independent people, than the bold and commanding turn of his natural genius.

His military courage and activity are spoken of with admiration, both by his own subjects; and the nations with whom he was engaged either in wars or alliances. He seems to have been naturally disposed to mildness and clemency; and though it is impossible to acquire sovereign power, and perhaps in Asia, to maintain it without crimes, yet the memory of no Eastern prince is stained with fewer acts of cruelty and injustice.

In his personal character he seems to have been cheerful, affable, and good-natured. He maintained considerable dignity on state occasions; but at other times his manners were 
plain and familiar; and with the Dooraunees he kept up the same equal and popular demeanour which was usual with their Khauns before they assumed the title of King. $\mathrm{He}$ treated Moollahs and holy men with great respect, both from policy and inclination. He was himself a divine and an author, and was always ambitious of the character of a saint.

His policy towards the different parts of his dominions was, to rely principally on conciliation with the Afghauns and Beloches; with this differenee between the nations, that he applied himself to the whole people in the first case, and only to the chief in the other. His possessions in Toorkistaun he kept under by force; but left the Tartar chiefs of the country unremoved, and used them with moderation. T'he Indian provinces were kept by force alone; and in Khorassaun he trusted to the attachment of some chiefs, took hostages from others, and was ready to carry his arms against any who disturbed his plans.

It has before been observed that Ahmed did wisely in choosing to lay the foundations of a great empire, rather than to complete a small one. The countries under his dominion extended, at his death, from the west of Khorassaun to Sirhind, and from the Oxus to the sea; all of which were secured to him by treaties, or by actual possession : ancl had his plans been pursued, there is no doubt that a government sufficiently strong to have secured its own stability, would soon and easily have been introduced through the whole of this great empire.

The character of Ahmed's successor was, unluckily, very different from his, and it was in a great measure owing to the system of policy introduced by Timour, that the power of the Dooraunees first became stationary, and has since declined.

Timour Shauh was born at Meshhed in the month of December 1746. He was educated at his father's court, and accompanied him on many of his expeditions.

His situation did not lead him to adopt the character and manners of his countrymen, and he seems never even to have been perfectly familiar with their language. While he 
was yet a youth, he was stationed in the Punjaub, and afterwards was appointed governor of Heraut, where the bulk of the inhabitants are Persians.

He was at Heraut when Ahmed Shauh's illness became serious, and he set off for the hills of Toba to see his father before he died, and probably to watch over his own interests when that event should take place. Before he reached Candahar he received positive orders from the Shauh to return to his government, which he was obliged reluctantly to obey. These orders had been obtained by the vizeer Shauh Wullee Khaun, who had before this entered into a conspiracy, with Sirdar Jehan Khaun and some other Dooraunee chiefs, to set aside Timour, and secure the crown on Alymed's decease to Prince Solimaun, who was married to the vizeer's daughter, On Ahmed Shaull's death, the Dooraunee chiefs lield a council at Candahar, to fix on his successor; the vizeer recommended Solimaun, but another party, headed by Abdoollah Khaun Populzye (who held the great office of Dewaun Begee), declared for Timour. After long debates, the council broke up without having come to any resolution; and the vizeer, of his own authority, placed Solimaun on the throne. Abdoollah and his partizans withdrew, and raised their clans. to support Timour's claim.

When this news reached Ilimour, he marched for Candahar with the force of his government, and such of the Dooruunees and Eimauks as had adopted his cause. The vizeer' also endeavoured to collect his army, but his attempt was unsuccessful, and he found he had no resource but in submission; he accordingly repaired to the camp of Timour, but he was not allowed to see the prince, and was immediately tried and condemned to death on a charge of murder, brought forward to remove from the government the odium of his execution.

Timour Shauh, having now obtained undisturbed possession of his father's kingdom, gave way to his natural indolence. His whole policy was directed to secure his tranquillity: he never appears to have thought of aggrandizing himself, and all the operations in which he was afterwards 
engaged, were intended merely for the defence of his clominions. As he knew that a strong party had been formed against him among the Dooraunees, and that the execution of the vizeer had exasperated that tribe, he seems ever after to have regarded them with great distrust. He first showed this in removing the seat of government from Candahar, in the midst of the Dooraunee country, to Caubul, which is inhabited by Taujiks, the most quiet and submissive of all the subjects of the Afghaun monarchy. His choice of ministers showed the same disposition. His chief counsellors, during his whole reign, were Cauzy Fyzoollah, a Moollah of the obscure clan of Dowlut Shahee, and Lootf Ali Khann, a native of $\mathbf{J}$ aum, in Western Khorassaun. In general he left the great dignities of the state in the Dooraunee families on whom Ahmed Sliauh had conferred them, but by instituting new offices, and altering the duties of the old ones, he threw all the government into the hands of his own dependents.

The governments of the provinces, that were not left to their native chiefs, were bestowed on men of little weight or influence; by which Timour hoped to secure himself from rebellions, and obtained for the present prompt obedience to his orders, and complete control over the revenue.

His finances were well regulated, and he observed a strict economy; by which means he rendered himself independent of military expeditions for the ordinary expenses of his government, and was able to lay up a treasure against any unexpected emergency.

He retained the Doornunee chiefs about his court; but as he had no troops of their tribe at the capital, they were entirely in his power, and had no means of disturbing his government.

The only troops whom he kept at all times embodied, were his own guards, the Gholami Shauhs, which were strong enough to keep the country in order, and being mostly Persians and Taujiks, were unconnected with the Afghaun chiefs or people, and entirely devoted to the King. These troops were well paid, received much countenance from the King, 
and were invested with some privileges of a nature which tended to separate them from the rest of the people.

This policy succeeded moderately well in maintaining internal tranquillity: the provinces immediately under the King remained quiet, and though there were some conspiracies during this reign, and two rebellions of pretenders to the throne, they were either discovered by the King's vigilance, or defeated by his full treasury and his well appointed guards; but the remote provinces gradually withdrew themselves from the control of the court; the government lost its reputation and influence abroad; and the states which had been obliged to preserve their own territories by submission to Abmed Shauh, now began to meditate schemes for aggrandizing themselves at the expense of the Dooraunees.

The decay was not severely felt in Timour Shauh's time: but its commencement was even then observable, and it has advanced by rapid strides under the reigns of his successors.

The first remarkable event of Timour's reign was the rebellion of his relation Abdoolkhaulik Khaun, which proba. bly happened in 1774-5. Abdoollshaulik succeeded in assembling a force of Dooraunees and Ghiljies superior in numbers to those the King had embodied; the latter, however, were disciplined troops under experienced leaders, and would probably have been victorious even if a determined resistance had been offered; but two chiefs, who were supposed to have raised their clans for Abdoolkhaulik, carried them straight to the King, and an unexpected turn of this kind is generally decisive in a Dooramee civil war. Abdoolkhaulik was defeated, taken and blinded, and the tranquillity of the Dooraunee country was soon restored. From this, till $178 \mathrm{1}$, though there were insurrections of various extent and consequence in Bulkh, Khorassaun, Seestaun, and Cashmeer, yet there is but one which requires particular notice.

It took place in the year 1779 , and was undertaken by the Sahebzadeh of Chumlcunee, a dervise of great sanctity, for the purpose of murdering Timour Shauh, and placing his brother Prince Secunder on the throne. The instrument he 
employed was Feizoollah Khaun, a chief of the Khulleels, who entered on this conspiracy as the means of revenging his private wrongs.

This man obtained the King's permission to levy troops for an attack on the Punjaub, and soon assembled a considerable number of Afghauns, chiefly of the Khyber tribes. When his plot was ripe for execution, he marched his troops to the citadel of Peshawer, on pretence of showing them to the King; when he reached the citaclel, he put the guards at the gates to death, and rushed with all his troops into the place. Timour Shauh had only time to retire to the upper story of one of the buildings of the palace, from whence he made his situation known to his guards. The Gholami Shauhs, and the few Dooraunees who were there, immediately assembled, and made a terrible slaughter among Feizoollah's men. Feizoollah and his son were taken prisoners and put to death, after having endured the torture without discovering their accomplices. Strong suspicions afterwards fell on the Sahebzadeh, and the King was so far convinced of his guilt as to order him to be seized; but the whole of the Afghaun chiefs at court interposing in his favour, no further inquiry was made.

1t is not the least remarkable circumstance in this singular attempt, that very few of Feizoollah's troops were acquainted with his design against the King, and that, on discovering his intention after they had reached Balla Hissaur, many of them refused to stand by him. Among these was a nephew of his own, whom he cut down at the gate for refusing to enter the palace. No distinction was made between the innocent and the guilty in the slaughter which followed.

In 1781, Timour Shauh went in person to recover Moultaun, which had been betrayed by the governor into the hands of the Siks. He sent a light force in advance against a Sik army near Moultaun, which moved on by very rapid marches, surprised the Siks, and totally defeated them. The city was taken after a siege of a few days, and the garrison was ordered to be escorted to their own country; but from 
want of discipline in the army, they were afterwards attncked and pillaged, and some of them murdered.

About this time broke out the rebellion of the Talpoorees, which ended in the expulsion of the governor of Sind. In the course of the next year the King sent a force under Muddad Khaun to reduce the insurgents, which soon overran the whole province. The Talpoorees retired to their original desart, and the other inhaljitants appear to have fled to the hills and jungles to avoid the Dooraunee army. Muddad Khaun laid waste the country with fire and sword; and so severe were his ravages, that a dreadful famine followed his campaign; and the province of Sind is said not yet to have recoverel from what it suffered on that occasion. At last, Muddad Khaun returned to Candahar, leaving the deposed governor in undisturbed possession of the province; but this quiet was of short duration : the Talpoorees returned as soon as Muddad Khaun had retired, again expelled the governor, and recovered the whole of Sind.

Timour Shauh allowed a consiclerable time to pass before he made any further attempt to reduce Sind, and it was probably as late as 1786 that he sent another army into that country, commanded by Ahmed Khaun Noorzye. This army was inferior to the first in force, and was eviclently unskilfully commanded. The Talpoorees did not now fly from Sind, but collected troops and moved against Ahmed Khaun, who suffered himself to be led into an amlunscade, was defeated with great loss, and compelled to retreat to Shikarpoor. The Sindees who had before sent a valeel to Timour: Shauh, now redoubled their efforts for an accommodation. Their vakeel appeased the King by the most humble professions, secured the ministers by great bribes, and at last, on the Talpoorees agreeing to pay the former revenue to the King, a rukkum was issued appointing the principal of then, Meer Futteh Ali, to the government.

The reduction of Azaud Khaun's rebellion in Cashmeer: took place during the interval between the expeditions to Sind and that against Bahawul Khaun, in the beginning of 1788, but notling of general importance to the kingdom 
occurred till the summer of that year, when a war broke out with the Uzbel Tartars. Shauh Moraud Bey, King of Bokhaura, had long been encronching on the Dooraunee dominions, and during the King's expedition to Bahawulpoor he carried his aggressions so far as to oblige Timour Shauh to take decisive mersures for the defence of his northern provinces. A letter which Timour Shauh wrote to Shauh Moraud on this occasion, is in many people's hands at Caubul. It contains a clistinct statement of the grounds of the war, and gives a clear view of Shaul Moraud's policy at that time. It states "that Ahmed Shauh had always been' on friendly terms with the State of Boklnaura: that Timour had maintained the same relations: that Shauls Morand had for sorne time been encroaching on the Dooraunee empire, and had always averted a war by speedy explanations and humble professions; taking care, however, always to sccure the point he had in view : that he had at last seizerl Mour** (or Merve), and driven away the Sheealı inhabitants, and had given as a reason his wish to convert them to the true Mahommedan faith: it urges that no state can have a light to interfere with the subjects of another on account of their religion; and then points out the inconsistency of Shauh Moraud's zeal on this occasion, with his detaining Timour Shauh by his encroachments from clearing Indin of Hindoos, Jews, Christians, and other unbelievers; and with his wars against the people of Shehr Subz and Klojend and the Toorkomauns, who were undonbted Soonnees." Timour Shaub says, "these nations have appealed to him, and he has been determined by Shauh Moraud's conduct towards himself, to take up their quarrel: he then announces his intention of moving inmediately to Toorkistaun, and requires Shauh Moraud to come to him in person to settle theiv differences."

In the spring of 1789 , Timour Shauh marched from Caubul with an army which his subjects reckon at a hundred thousand men. He went by short marches, to allow

* Cu?led Mour by the Uzbelis, and Merve by the Persians.

VOL. II. 
time for overtures from Shauh Moraud; and he was delayed for a short time by a march towards Coondooz, after which he advanced to Aukcheh, the nearest town of the territory seized by the Uzbelss. On this, Shauh Moraud crossed the Oxus at Killif, with troops drawn from all parts of his tominions and their dependencies. He sent on his brother, Omar Kooslibegee, to Aulcheh with a light force, while sllaverclee 'Tauz, of Koorghan Tippeh, cut off the pro. visions and foragers of the Dooraunee army. Some partial and indecisive actions took place at Aukcheh, and Sliauh Moraud hand met with no serious check, when he perceived that it was for his interest to make peace; he accordingly opened a negotiation, which he condneted with the skill ind atliress for which he was celebrated, and with complete surcess.

Ile was aware that Timour Shauh entered upon the war with reluctance, and would be happy to withdraw from the fititrue and clanger of an Uzbek campaign, if he could do so without losing his reputation. He therefore gave him the credit of a victory: and sent the principal Moollahs and religious men of Boklaura to him to conjure him, by the Koraun, and lheir common frith, to spare the blood of the Mussulmauns by yiclding to lis supplications for peace. l'ate was accordingly made, and Sluauh Moraud's son was sent to 'Tinour's camp, where he was honourably received, and immediately disnissed. Through the whole transaction, Shauh Moraud showel the utmost respect and submission to Timour Shauh; but he retained all his conquests at the peace; while the other failed in every object of his expedition, except that of securing his remaining dominions.

The winter was so far advanced before Timour marched on his return, that lie was forced to leave his artillery in Bulkh, and many of his troops perished from the cold and snow in crossing the Indian Caucnsus.

Arsilla Khaun, clief of the Upper Momunds, who had more than once distinguished himself in Timour Shauh's foreign expeditions, had rebelled during the war in Toor- 
kistaun, and had infested the roads between Peshawer and tlic capital. *

He afterwards gave himself up to the prince who commanded at Peshawer; and Timour, without regarding his voluntary surrender, or the prince's solicitation for his pardon, ordered him to be delivered to some of his tribe with whom he had a deadly feud, and by them he was immediately put to death. This circumstance is regarded by the Afghauns as a great stain on Timour's memory.

In the spring of 1793 , Timour Shauh was taken ill on a journey from Peshawer, and died at Caubul on the 20th of May 1793.

At the time of 'l'imour Shauh's death, $\uparrow$ nothing was settled respecting the succession to the throne. He had himself named no heir. The eldest and the most conspicuous of the princes was absent. Hoomayoon was governor of Canclahar, and Mahmood held the same office at Heraut. Prince Abbass was governor of Peshawer, but had joined his father on hearing of his illness. The other princes were all at Caubul, except Ferooz the full brother of Mahmood, who was with that prince at Heraut.

Timour Shauh was no sooner dead than an intrigue was

* Arsilla Khuun was at one time compelled to disperse his followers, and to take refuge in the country of the Otmaun Khail; and the following circumstance of his reception by that tribe is highly characteristic of Afghun manners.

When Arsilia Khaun approached the first village of the Otmaun Khail, the heads of the village, alarmed at the prospect of drawing the King's displeasure on themselves, went out to meet the fugitive, and told him that their granting him the rigbts of hospitality would involve them in a contest with the King, to which they were perfectly unequll, and that they had therefore resolved to refuse him admittance into their village. Arsilla Khrun endeavoured to excite their compassion, and while they were engaged in conversation with him, he sent a part of his baggage into the villige by a circuitous route; when the chiefs found that Arsilla's people had entered their villige, they inmediately acknowledged that he was now under their protection, received him hospitably, and summoned their tribe to defend him.

t The facts contained in the following puges are entirely drawn from: Mi. Alexander's history. 
set on foot to secure the crowu to Shauli Zemaun. It was carried on by 'Timour Shauh's favourite queen, who prevailed on Sirafrauz Khaun, the head of the Baurikzyes, to join in her scheme, and by his means secured the interest of most of the Dooraunee Khauns.

The princes of the royal family made an attempt to raise Abbass to the throne, but, though they behaved with much spirit, they showed little skill: their persons were secured by a stratagem: the gates of the Balla Hissa, or citadel of Caubul, were seized by Zemaun's partisans: and that prince was declared King in a hasty meeting of the Dooraunee chiefs. He was immediately proclaimed, a largess was issued to the guards, the princes were sent into confinement in the upper fort of Caubul, and from that moment Shauh Zemaun entered quietly on the administration of the government.

Means were taken for assembling an army to establish the authority of the new King, and to subdue the rebellions that might be expected from his brothers.

His greatest apprehension was from. Hoomayoon, who was certainly entitled to the throne if primogeniture gave a claim, and who commanded at Candahar, in the heart of the Dooraunee country. He was, however, unpopular; he was deserted by some of his adherents, was defeated by a small force commanded by Prince Shujall (since King), and was compelled to take refuge in Belochistaun. Shauh Zemaun took possession of Candahar, and soon after received the submissions of Prince Mahmood, (who, as I have mentioned, was governor of Heraut,) and then set off for Caubul.

As soon as Shauh Zemaun had secured himself from his competitors for the throne, he appears to have determined on an invasion of India; a measure to which he was stimulated by Meerza Ashun Bukht, a prince of the royal family of Dehli, who had fled to Caubul in Timour's reign, as well as by ambassadors who arrived about this time from Tippoo Sooltaun, and who made great pecuniary offers to the King, on condition that he should attack the British. 
In the month of December 1793, Shauh Zemaun marched to Peshawer, with the intention of immediately invading Indin; but this resolution was soon clropt, from the Shauh's conviction that his own dominions were not sufficiently settled, to admit of his embarking in foreign expeditions. Great confusion had indeed arisen in the remote provinces immediately on the death of Timour, when the suspension of the powers of government, and the prospect of a disputed succession, encouraged foreign enemies, and induced ambitious subjects to attempt their own aggrandizement.

The most serious danger, that which threatened him on the side of Toorkistaum, had, however, passed over by this time. Shauh Moraud, who had been checked in his plans of conquest to the south of the Oxus by the exertions of Timour Shauh, invaded Bulkh immediately on that monarch's death. Mahommed Khaun Seeah Munsoor, the King of Caubul's governor, an officer of great activity and courage, was drawn into an ambuscade with the greater part of his force, amounting to four thousand men, and was taken prisoner in the defeat which ensued. Shauh Moraud, expecting to profit by the consternation of the remaining troops, immediately advanced against the capital of the province; but the garrison showed a spirit which could scarce have been expected in such circumstances : the principal Dooraunee chiefs took the management of affairs on the capture of their governor, and prepared for a vigorous defence. The extensive and ruinous cicy of Bulkh was abandoned; but the fort held out for three or four months, notwithstanding the utmost exertions of the enemy. Among other attempts to reduce the place, Shauh Moraud made use of the savage expedient of producing the governor uncler the walls, and offering to the garrison the alternative of procuring his liberty by an immediate capitulation, or of seeing him put to death, if they refused to surrender. The garrison adhering to their resoIution to defend the place, Shauh Moraud's threat was barbarously executed before their eyes. At last Shauh Zemetun arrived at Caubul, after his success in Khorassaun, and Shauh Moraud, who expected that he would immediately 
march to the relief of Bulkh, sent ambassadors, offering to give up his claims on that province, on condition of Shauh Zemaun's observing the treaty formerly conclurled with Timour Shauh. Shauh Zemaun, who was at that time intent on the invasion of India, readily consented; and peace was concluded about the time of the King's arrival at Peshawer.

The remaining months of 1793 , and part of 1794, were occupied in reducing Cashmeer, which had rebelled on Timour's deatl, and in settling the southern provinces, whither the King went in person: on that occasion he compelled the Ameers of Sind to pay two million four hundred thousand rupees on account of the tribute due from them, after which lie ruturned to Caubul.

He did not long remain at the capital, for Mahmood, who had only submitted from necessity, had now again rebelled, and the King soon after moved out against him at the head of fiftcen thousand men. The princes met at the Helnund, and a well-contested action took place, in which Shauh Zemaun, after nurrowly escaping a defeat, obtained a compiete victory. Almost all the chiefs of the Eimauks, and many Dooraunees of rank, fell into his hands. These were all pardoned and released: Mahmood fled from the field of battle, and reached Heraut in safety.

The King, after sending a force to take possession of Furrah, returned to Candahar, from whence he proceeded to Peshawer, and again began to collect an army for his favourite project of invading India.

Before he left Candahar, he had despatched Sheer Mahommed Khaun (son of the Vizeer Shauh Wullee) to settle the government of Belochistaun. Nusseer Khaun died in the spring of this year, 1794, and was succeeded by his son Meer Mahmood: his claim to the government was contested by Behraum Khaun, a nephew of Nusseer's, who had defeated Mahmood, and made himself master of a large portion of Belochistaun. Sheer Mahommed's mission was attencled with success : he defeated Behraum, put all his strong places into the hands of Mahnood, and left the Beloche govern- 
ment to all appearance restored; but that government had received a shock which it has never since recovered. The tribes in the south-west of Belochistaun had been but lately conquered by Nusseer, and were never perfectly subdued. They seized the occasion offered by these distractions to throw off their allegiance: and Mahmood, whose spirit and capacity are very inferior to his father's, has never been able to recover much more than a nominal sovereignty over them. Meanwlile Shauh Zemaun's designs against India were again frustrated by fresh disturbances excited by his brother Hoomauyoon. This prince had been confined by Nusseer Khaun, but had effected his escape, and after a series of aclventures, had succeeded in collecting an irregular army. Fortune, however, enabled him to gain an unexpected victory, the result of which was the capture of Candahar ; but Shauh Zemaun soon returning to the west, Hoomauyoon's troops cleserted him, and it was not without difficulty that he escaped to the hills.

Shaul Zemaun then returning to Peshawer, Hoomauyoon again appeared at the head of a force, but he was defented by the King's lieutenants, and after a long flight he was seized at Leia, on the east of the Indus, was blincled, and passed the rest of his life in confinement.

Thus far Shauh Zemaun's government had proceeded with reasonable conduct, and with great success. His claim to the throne was now undisputed, and his authority established over all the country left by Timour Shauh. The King himself was active and enterprizing, and his capacity seemed sufficient, with the support of those qualities, to have remedied the mistakes of his father's administration, and restored the Dooraunee affairs to the train in which they were left by Ahmed Shauh.

Notwithstanding some defects in his character, and some erroneous maxims in his policy, Shauh Zemaun would probably have fulfilled these expectations, if he had resolved to govern for himself; but by committing the whole of his powers and cluties to an unworthy favourite, he involved himself in a system of measures which was 
ruinous to his own fortumes and to the prosperity of his nation.

The first object of his attention ought to have been to secure the support of his own tribe, on which so much depended in the original plan of the monarchy; had he succeeded in this particular, the internal quiet of his country would have been at once secured. In his foreign policy, his first object ought to have been to defend Khorassaun. The power of Persia was now consolidated in the hands of an active prince, who had already turned his attention to the conquest of that province, and some exertion on the part of Shauh Zemaun was obviously required to check his progress; such a course was indeed necessary to the success even of his eastern expeditions. India was as much altered as Persia since the time of Ahmed Shauh, and nothing was to be gained there but by long and uninterrupted operations. There were no longer treasures at Dehli to reward a march to that city; and the more desirable object of reducing the Punjaub, was not to be accomplished by a hasty incursion. The plan opposed by the Sils to Ahmed Shauh, which was to evacuate their country on his approach, and return when his army was withdrawn, could only be baffled by keeping a force in the country sufficient to retain possession: and that measure could only be accomplished when the western frontier was secure.

The plan actually adopted by Shauh Zemaun was almost the reverse of that which has been sketched. He widened the breach between the Dooraunees and the court: he made no serious effort to save Khorassaun: and his ill-directed and ill-timed attempts at Indian conquest, teuded only to frustrate that fnvourite object of his ambition.

The source of all his errors was his choice of Wuffadar Khaun for the office of vizeer, and the implicit confidence which he reposed in that minister. Wuffaclar was a Suddozye who had gradualiy gained the King's confidence by his supple and insinuating manners, and had used his ascendancy to overturn the power of Sirafrauz Khaun, and all the great officers of the army and state : he seems to have 
perfectly understood the disposition of his inaster, who, though prond and imperious, was easily led by flatterers, and who, with all his fondness for activity and enterprize, had not patience or application sufficient for manaing the cletails of business. He was ambitious and haughty to those who might claim equality with him, and jealous of any who could attempt to rival him in power or favour; but his arrogance and confidence in council were equalled by his timidity when exposed to personal dangrer, a circumstance which added contempt to the dislike with which he was otherwise regarded. His elevation and his subsequent conduct disgusted the Dooraunees ; and, sensible of the ill will they bore him, he used every art to infuse jealousy and dissension between that tribe and the King. His avarice was not less hurtful to the state than his ambition : the governments of provinces and other offices were openly sold for his profit; and the decline of the revenue, which was the consequence of his embezzlements and those of his creatures, was severely felt under a prince whose operations were so expensive as Shauh Zemaun's, and who had no share of the order and econony which distinguished his predecessor.

The rest of Shauh Zemaun's reign was spent in attempts to invade India, from which he was always rccalled by the pressure of dangers which he had left unprovided for in the west. Had he been allowed to have pursued his plan without interruption, its original defects would have boen only the more conspicuous : he might have taken Dehli from the Mahrattas, but the plunder would not have paid the expenses of his advance; and if the invitation of the Rolillas, and the temptation of seizing the wealth of the vizeer, liad led him on towards Lucknow, he would lave been opposed by the army then formed for that purpose under Sir James Craig: there can be little doubt, from the Dooraunee mode of war, that he would have engaged it, and still less that the result would have put an end to his projects in India.

Shauh Zemaun's first invasion of the Punjauls was commenced at the close of the year 1795 . He crossed the Indus 


\section{KHORASSAUN INVADED BY THE PERSIANG.}

by a bridge of boats at Atcock, and advanced three marches to Hussun Abdaul, from which place he detached a large force under Ahmed Khaun Shauheenchee Baushee, to take possession of Rotass. This detachment succeeded in its object, and was joined by many Guckers, Juts, and other Mussulmauns of the Punjaub: while the Silss fled in dismay to the mountains or beyond the Hyphasis.

Their alarm was, however, soon dissipated ; for the King had only been a week at Hussun Abdaul, when he received intelligence of the invasion of the west of Khorassaun by Agha Mahommed Khaun Kujjur, King of Persia : this attack determined him immediately to return to the defence of his dominions; and with such precipitation was his resolution executed, that he made but two marches from Hussun Abdaul to Peshawer, ${ }^{*}$ where he arrived on the 3rd of $\mathrm{J}_{\mathrm{a}}$ nuary 1796.

'The Persian invasion had been designed for the capture of Meshlsed, where great discontent prevailed against the family of Naudir Shauh. Naudir Meerza, the efficient ruler of the place pursued a plan which had succeeded on a forner occasion, and fled to Caubul as the Persians approached: lis father, Shauh Rokh, was cletained by his age and infirmitics, and threw himself on the mercy of the conqueror; but his submission dirl not soften Agha Mohammed, whose disposition, naturally barbarous and unrelenting, was exasperated by the injuries which himself and family had suffered from Naudir Shauh. Shauh Rokh was seized on entering the Persian camp, torture was applied to malse him give up his treasures, and after enduring all the torments which the cruelty and avarice of his persecutor could suggest, the old and blind grandson of Naudir Shauh was murdered in the Persian camp. Agha Mahommed then entered Meshlherl, clestroyed the tomb of Naudir Shauh, dug up that conqueror's bones, and sent them to Tehraun. It is remarkable that Naudir's family should be massacred and his grave dishonoured by Persians, after lsaving been so long protected by the nation from whose yolse he had delivered his country.

* Upwards of seventy-seven miles. 
As Meshhed had long been clependent on Caubul, this attack gave great cause both of indignation and alarm to Shauh Zemaun, and at first he seems to have been influenced by those feelings : he returned to Caubul prepared for war, and proposed to the Uzbeks to enter into a league against the Persians; but his ardour soon cooled, and an embassy from Agha Mahommed, together with the retreat of that monarch, succeeded in making him give up all fear for his remaining territories, and drop all thoughts of revenging the indignity he had suffered. Shauh Zemaun's infatuation for Indian expeditions seconded the views of the Persians on this occasion; and no sooner had Aglia Mahommed withdrawn than he set out for Peshawer, and prepared to return to the Punjaub. He assembled a force of thirty thousand men, of whom one half was Dooraunees; and in the end of November he began his march for India, and advanced unopposed to Lalıore, which he entered on the 3rd of January 1797.

Shauh Zemaun's general plan for reducing the country was founded on the practice of Ahmed Shauh. He sent frequent Chepawuls (light parties moving by rapid marches) to attack the Siks in their retreats, to drive away their cattle, and seize or destroy their grain: he reduced such forts as were within his reach, and at the same time lie gave great encouragement to any Sik chiefs who would submit to him. His plan was in some measure obstructed by the persuasions of his bigoted Moollahs, by the rapacity of the vizeer, and by the licence of the soldiery; but in spite of those unfavourable circumstances, he made some progress in inducing. the Siks to join him, and several of their chiefs attended his court at Lahore.

The advance of the Dooraunee army, and the occupation of Lahore, did not fail in creating a strong sensation throughout India. The wealnness of the Mahrattas, the whole of whose forces were drawn to the southward by their own dissensions; the feebleness of the government of the Nabob Vizeer, and the disposition of the greater part of his subjects to insurrection and revolt, together with the anxiety of all the Mahommedans for the prevalence of their religion, and for the 
restoration of the house of Timour, had prepared that country for a scene of disorder and anarchy which would cloubtless have opened as soon as the Shauh had advanced to Dehli. This state of affairs was early perceived by the powers whose safety was tlireatened. The Mahrattas indeed were struck with dismay, and made little preparation to defend themselves, except by soliciting the assistance of their neighbours; but the British government adopted more vigorous measures, and sent a powerful army to Anoopsheher to defend the frontier of its ally the Nabob Vizeer.

Nor were the partizans of Shauh Zemaun more inactive; intrigues were set on foot in many parts of Hindoostaun for the purpose of co-operating with that prince's invasion: the Rohillas had begun to assemble in arms, and every Mussulmaun, even in the remotest regions of the Deccan, waited in anxious expectation for the advance of the champion of Islaum. These hopes and these apprehensions were dispelled for the time by the failure of Shauh Zemaun's expedition; but the impression of his actuance was permanent. Some years elapsed before the Mahrattas were relieved from their expectation of the appearance of another Ahmed Shauh : and the principal object of the British mission to Persia in 1799 was to secure a three years' suspension of the threatened attack of Shauh Zemaun.

Shand Zemaun's retreat in 1797 was occasioned by intelligence which reached him of a rebellion in his own dominions. Prince Mahmood, though still allowed to retain his government of Heraut, had shown an inclination to rebel before the King set out for India, and during his absence he had assembled an army of twenty thonsand men, mostly Persians of Khorassaun, with which he would probably have attaclied Candahar, had he not been prevented by the King's speedy return.

Shauh Zemaun marched against him from Candahar on the 8th of September 1797, and although his own injudicious arrangements had nearly exposed him to defeat, yet the effects of his imprudcnce were counteracted by the trenchery of Mahmood's adherents; Killich Khaun Teimoree seized 
the citadel of Heraut in his name, and was joined by the Dooraunee governor of the city: the army followed the example of disaffection, and Mahmond, reduced to despair, fled to Toorshish with his son Caumraun.

Shaul Zemaun immediately entered Heraut : two of Mahmood's advisers were executed for this rebellion, but no other measures of severity were adopted. These arrangements occupied Shauh Zemaun for some time, but as soon as he had a moment's leisure he turned his attention to the Punjaub, where his cause had met with some reverses while he was engaged in the west. As soon as he had quitted the country, the Siks returned from their hiding-places, and began to retaliate on the Mussulmauns the oppression which those of their own religion had suffered from the Dooraunees. They had even cut off a party of five thousand eastern Afghauns which had advanced to the Hydaspes under a chief of the King's; and the whole of the Punjaul was as far as ever from being conquered, when the King set out on his third expedition. He set off from Peshawer on the 25th of October, 1798, and advanced without molestation to Lahore. He persevered in his plan for conciliating the Silks, and by all accounts no outrage of any sort was offered to the inhabitants of the Punjaub during this campaign. Many Silk chiefs and all the Mussulmaun Zemeendars attended the court, and before the King withdrew all the chiefs had done homage in person, or through their agents; and among the former was Runjeet Sing, now King of the Siks.

About the end of 1798 the Shauh received news of an invasion of Khorassaun by Futteh Ali Shauh, King of Persia, and set out on his return to Peshawer, which he reached on the 30th of January, 1799. His guns were lost in the Hydaspes, on his return, by a sudden rising of the river; but they were afterwards dug out and restored by Runjeet Sing and Saheb Sing.

After a short stay at Peshawer, Zemaun repaired to Heraut, where he resolved to stay the rest of the year; and he now appears at last to have seriously turned his attention to the defence of his western dominions. This disposition 
may have been produced by the presence of his lyrother Mahmood in the Persian army, and the fear of his receiving such support from the Persinns as should enable him to retake Heraut, or at least to secure for himself some other part of the Dooraunee dominions in Persian Kloorassaun. $\mathrm{He}$ had not, however, been long at Heraut, when he received accounts of the retreat of Futtel Ali Shaul, who had failed in all his attempts in Khorassaun; and soon after Shauh Zemaun withdrew to Candahar, where he remained during the winter of 1799 .

Not long after Zemaun had arrived at Candahar, an unsuccessful attempt was made on Heraut by Shaul Mahmood.

The flight of that prince to Toorshish, on the taking of Heraut (in 1797 ), has already been mentioned; he soon after repaired to the Persian court, where he was kindly received.

In the spring of the next year (1798), he left the court and retired, first to Cashaun, and then to lspahan. He remained there till the spring of 1799, when he accompanied the King of Persia on the expedition into Khorassaun, which I have just mentioned. He remained in Khorassaun after the King of Persia had retired, and endeavoured to stir up some of the chiefs of that country to assist him in the attack on Heraut. After failing in Toorshish and Tubbus, he succeeded in procuring the support of Mehr Ali Khaun, the ruler of Kauin and Berjend, and he now advanced against Herant with ten thousand men belonging to that chief. $\mathrm{He}$ must have marched from Berjend within a month or two after Shauh Zemaun left Heraut.

At Izfezaur he was encountered by a force sent by Prince Kysej from Heraut, which he defeated. He then advanced and invested Heraut : his operations were at first successful, but Wuffadar having managed by an artful expedient to render Mahmood suspicious of a design on the part of Mehr Ali to betray him, that timid prince suddenly quitted his camp in the night, and Mehr Ali was obliged to retreat with precipitation to his own territory, which he reached after encountering great difficulties in the desart tract between $\mathrm{He}$ raut and Berjend. 
Mahmood in the mean time continued his flight into Tartary, and at last reached the court of Bokhaura. He there met with a friendly and honourable reception, and had remained for some time at one of the King's palaces, when an agent arrived from Shauh Zemaun to remonstrate with Shauh Moraud for granting him an asylum, and to request that the King of Bokhaura would deliver him up to his own sovereign, against whom he had rebelled. The agent is said to have been authorized to promise a large pecuniary gratification to the King of Bolhoura on Mahmood's being delivered up. It is not quite certain how these applications were received : there can be little doubt that Shauh Moraud replied to Zemaun's demand by very flattering professions. It is commonly believed that he was about to deliver up Mallmood, when that prince declared his intention of making a pilgrimage to Mecea, and by thus introducing religion into the question of his liberation, interested the Ulima in his favour, and by their influence obtained leave to depart; but a more probable account is, that Shauh Moraud, equally unwilling to offend Shauh Zemaun by harbouring his rival, and to sacrifice his own reputation by betraying a guest, gave Mahmood notice of the machinations that were carrying on against him, and prevailed on lim to remove all difficulty by quitting his dominions. On leaving Bokhaura, Shauh Mahmood fled to Khoarizm (or Oorgunge), where he was well received by the King. From Oorgunge he again returned to Persia.

During the time of Mabmood's wanderings, an event took place at Candahar which had a material effect on his future fortunes. Six of the principal Dooraunee and Kuzzilbaush lords, disgusted with the power and insolence of Wuffadar Khaun, had conspired to assassinate that minister, to depose Zemaun, and place his brother Shujah on the throne. The conspirators met often, and notwithstanding the precautions they observed, had at last excited Waffadar's suspicions, who had surrounded them with spies without being able to penetrate their design, when the whole plot was unexpectedly revealed by Meerza Shereef Khaun, the deputy of the Moonshee 
Baushee, to whom the secret had been disclosed by one of the conspirators.

The principal conspirators were Sirafiauz Khaun, head of the Baurukzyes, Mahommed Azeem Khrun, head of the Alleklozyes, and Ameer Arslaun Khaun, head of the powerful Persian tribe of Jewaunsheer.

Mahommed Azeem, the most dangerous of the number, was first seized. An officer was then sent to apprehend Sirafrauz Kliaun. On his arrival at the house of that nobleman he was received by his son Futteh Khaun (the same who has since made so great a figure in the Dooraunee transactions). Without showing any suspicion of his intentions, Futteh Khaun apologized to the officer for his father's absence, and offered to go and call him: he then repaired to Sirafrauz, told him that a guard was come to seize hins, and with the same decision and the same inclifference to the means which lave since characterized him, proposed to assassinate the officer, seize the guards, and fly from Candahar. Sirafrauz rejected these violent counscls, and attended the officer to the King. Ameer Arslaun was at court when the order for seizing him was issued, and the other conspirators were apprehended at their own houses.

Next morning they were summoned before the King, and all beheaded. A short time after this execution the Ameenool Moolk, and Hookoomut Khaun Allekkozye were also put to death ; and the King's and his minister's fears from this conspiracy were entirely removed. But the indignation excited by these sanguinary measures had, in reality, increased their danger, and it is from this time that the spirit of rebellion which occusioned the downfall of Shauh Zemaun took its rise.

In the spring of 1800 Futteh Ali Shauh a second time invaded Khorassaun. He was accompanied by Mahmood, whom he promised to place on the throne of Caubul. Shauh Zemaun marched to Heraut as soon as he heard of the advance of the King of Persia: he remained there during the summer, and early in autumn he set off, and proceeded with the greatest possible expedition to Caubul. He sent his 
army by the usual route, and went himself, with two or three thousand choice troops, through the Eimauk country, and the almost inaccessible mountains of the Hazaurehs. He made prodigious marches, and, as the road he chose was quite direct, he reached the capital in less than a fortnight. Futteh Ali Shauh retired from Subzwaur at the same time that Shauh Zemaun left Heraut.

Shauh Mahmood, who was left in Khorassaun, retired to Tubbus in despair of assistance from the Persians, and extremely disgusted with the conduct of their court. He was still attended by Akram Khaun Alizye, and two or three other Dooraunee ehiefs who had shared in all his fortunes; his prospeets never wore a worse aspect than at this time: when the arrival of Futteh Khaun Baurikzye gave a new direction to his councils, and engaged him in an enterprize which ultimately led him to the tlirone. Futteh Khaun had fled to his eastle of Girishk on the death of his father, but had been compelled to quit it from his apprehension of the King's power. He was animated with the spirit of revenge and hatred to Shauh Zemaun and his minister; and his observation of the state of men's minds in the Dooraunee country was sufficient to determine a man of his sanguine eliaracter to malke a bold attempt to overthrow the government. His advice to Mahmood was to rely no longer on foreign aid, but to advance on Candahar, and trust to the Dooraunees for supporting his cause. The project must have been received with ardour by the Dooraunees, always disposed to bold enterprizes, and impatient of exile more than of all other calamities.

Shauh Mahmood left Tubbus with no more than fifty horsemen, crossed the desart into Seestaun, and advanced to Jellallabad, the capital of that province. He was received with open arms by Behraum Khaun, the chief of Seestaun, who gave his daughter to Prince Caumraun, equipped Mahmood's friends, already worn out with their long march in the desart, and proposed to assist that prince with the force of his province. His offer was rejected in pursuance of Futteh vOL. II. 
Khaun's plan, and Mahmood entered the Dooraunee country with the remains of his exhausted party.

His adviser had not misjudged the disposition of his countrymen: the Dooraunees flocked to Mahmood, and on his advance to Candahar he assembled so great a force as to be able to face the Meer Akhor,* who had been left in command of the province. That officer encamped under the place till he was so much distressed by the partial but frequent attacks of the enemy, that he was obliged to retire within the walls.

The place was then invested by Mahmood, whose army continued to increase till the forty-second day of the siege, when Futteh Khaun contrived to get himself introduced, almost alone; into the town, and immediately threw himself on the lionour of Abdoollah, a powerful chief of the garrison. The force of this method of solicitation is explained in another place; it had complete effect in this instance; Abdoollah declared for Mahmood, the Meer Alkhor was compelled to fly, and Candahar opened its gates to the rebels.

While these things were passing, and even after accounts. of their commencement had reached him, Shauh Zemaun was assiduously employed in preparations for another invasion of Hindoostaun. It was not till he heard of the fall of Candahar, by which time he had arrived at Peshawer, that he was roused from this infatuation. He then gave up his plans on India, and returned to Caubul.

He did not, however, leave Peshawer without cummitting some fatal acts of imprudence.

Abdoollah Khaun Allekkozye, the governor of Cashmeer, had come to court, and was seized and tortured; on which his brother, Sydaul Khaun, who was at Candahar, went over to Mahmood with his whole clan (the Alleklkozyes). Zemaun next detached an army of fifteen thousand men against Cashmeer under Moollah Ahmed and Meer Vise Noorzye. This force, which might have been so well employed in quelling Mahmood's rebellion, was dispersed before it reached Cashmeer by the imprudence of its commander Moollah Ahmed.

* Master of the Horse. 
Shauh Zemaun left a considerable force at Peshawer under his brother Shujah Ool Moolk, and seems to have had no sense of the general disaffection, but to have reckoned on defeating Mahmood without any great exertion. When he reached Caubul the true state of affairs broke in on his mind, and his security was succeeded by the utmost disquiet and alarm. Aware of the disaffection of the Dooraunee chiefs, he scarcely thought himself safe among them; his guards were doubled, and their customary appenrance at the court was changed into constant duty over the palace. The King's distrust of his own tribe was farther marked by his anxious endeavours to gain the Ghiljies; and these precautions, while they gave confidence to the disaffected, disgusted many who were neutral or well disposed. The terrors of the rizeer were still more conspicuous; and, from his known timidity, it is probable the panic had seized him before it infected the King. He was more difficult of access than ever, his manner was become suspicious and distracted, and his resolutions were hasty and wavering. The distrust which the court showed of its own fortune: soon spread to the people, and, in a superstitious nation, omens were not wanting to confirm their expectation of some great reverse.

After some vain negatiations, the King marched against the rebels with thirty thousand men: he sent on two parties in front of his army, of which the most advanced was under Almed Khaun Noorzye, and the King soon after fell into the rear, and ever after remained a march or two behind the array; a plan probably suggested by the fears of the minister, which added to the alarm of the troops.

Alhmed Khaun had many insults and injuries to revenge on the vizeer, and so little was he trusted, that shortly before he got this important command, he was thought to have been marked aut for execution by the minister; yet in this extremity Wuffadar Khaun seized on the hope, that by conferring honours and flattering appointments on Ahmed Khaun, he could bring him over to his interests. He was accordingly entrusted with the command of the vanguard, 
the conduct of which former experience had shown generally to decide the fidelity or desertion of the army.

Ahmed Khaun was, however, undetermined what line of conduct to pursue when he left the main body; at least Futteh Khaun thought he was so; and the steps he took to secure his co-operation, though perfectly consistent with the headlong violence of Futteh Khaun's character, would be incredible, if imputed to any other person. He seized Abdoollah Khaun, the brother of Ahmed Khaun Noorzye, and threw him into close confinement, threatening to put him to instant death if his brother did not come over. Abdoollah had joined Mahmood in an important crisis, and his fidelity was never doubted; but Futteh Khaun knew Alımed's attachment to his brother, and was very careless about the justice of his measures if they answered the end in view.

If Ahmed Khaun really wavered, this threat determined him; for when he met Mahmood's advance at Sirreeasp, he joined it with the whole body under his command.

The nain body, commanded by Prince Naussir, was at Aubitauzee, not far from Sirreeasp, when news was received that the advanced guards were near each other, and soon after that they had engaged; on which the army halted and entrenched. The fact of Almmed's desertion was soon after known, but produced no great sensation in the army. Its effect was different in the King's own little camp, where every decision was influenced by Wuffadar: all was given up for lost, and the King fled with precipitation towards Caubul. It was probably the knowledge of this desertion which first altered the conduct of the troops under Prince Naussir: they soon became so mutinous that the Prince was obliged to quit the army and fly towards Caubul; on which the army fell into entire disorder, and probably broke up.

A party of two thousand men, under Futteh Khaun, was immediately sent by Mahmood to Caubul, and he soon after marched himself in the same direction.

In the mean time Shauh Zemaun pursued his flight with the utmost precipitation till he reached the Shainwaree country, worn out with hunger and fatigue. The vizeer now 
proposed that the King should stop and refresh at the castle of Moollah Aushik, a dependent of his : the Meer Akhor remonstrated against the delay, but finding his arguments over-ruled he quitted the party, and after many adventures arrived safe at Peshawer. The King, attended by the vizeer and his two brothers, the Khaunee Moollah, the Shautir Baushee, and a favourite Peshkedmut, entered Moollah Aushilk's castle. The Moollah received them hospitably, but at the same time took measures to prevent their escape, and sent off a messenger to Mahmood, who was now at Caubul, to announce their seizure.

In the meantime Zemaun discovered that he was under restraint, and tried all means to persuade Moollah Aushik to refrain from an action so full of disgrace, as betraying a guest who was at once his King and his benefactor: these arguments failing, he had recourse to force, which also proved ineffectual. He then gave himself up to his fate, and bore his subsequent calamities with patience and firmness.*

Assud Khaun, a brother of Futteh Khaun's, was instantly dispatched to secure Zemaun; and soon after an officer was sent with a surgeon to put out his eyes. The messengers met Zemaun on his way to Caubul, and performed their orders by piercing his eyes with a lancet. He was then carried to Caubul, and confined in the Balla Hissaur.

He remained in confinement all Malımood's reign, but was released on Shujah's accession; he has since lived in comparative ease and comfort. Wuffader and his brothers were executed soon after their seizure.

Mahmood's accession was at first joyfully welcomed by all ranks of men. Wuffadar had disgusted the great by his systematic depression of their order, as well as the poor by his exactions; and the nation fondly hoped that by a change of government they might recover, if not the glorious and prosperous career of Ahmed the tranquillity which they had enjoyed under his son. But the character of Slauh Mah-

- During his confinement he secreted the Coheenoor, one of the most valuable diamonds in the world, with some other jewels, in the wall of his apartment, where they were afterwards found on Shujah's accession. 
mood was calculated to disappoint all their expectations : unprincipled, indolent, and timid, he shared as little in the cares of government as in the toils and dangers of war; and while his own ease and safety were secure, he was indifferent to the conduct of his ministers, and to the welfare of his people.

The government of the state was left entirely to Akram Khaun Alizye and Futteh Khaun Baurikzye. The first of these chieftains had all the characteristics of a Dooraunee nobleman. He was proud, high-spirited, and obstinate; frugal, but not sordid in expense, steady in his attachment to his party, and strict in conforming to the notions of honour which prevail among his countrymen. Futteh Khaun has since become one of the most prominent characters in the Dooraunee history, and now holds the office of vizeer, and enjoys the supreme power under the name of his reluctant sovereign. Excepting the short and turbulent period of Mahmood's success, the early part of his life was spent in intrigues and adventures, sometimes supporting a rebel force by plunder, and sometimes living in jealous and precarious friendship with the King. His character is such as such circumstances might be expected to form. As his misfortunes never reduced him to dependence, his spirit remains unbroken, and his activity undiminished. He is acknowledged on all hands to be a man of talents and courage, and by his own adherents he is greatly beloved. He attaches his followers by the most profuse liberality, and the utmost laxity of discipline. As he is unrestrained by principle, and accustomed to sudden reverses, he employs the opportunities that fortune throws in his way, without discretion or moderation, to enrich his adherents, and gratify their passions and his own. Though excessively addicted to wine, he never remits his vigilance over the interests of his party ; or, if he does, lis neglect is compensated by the promptitude of his resolutions, and his vigour and decision in executing them. In his person he is said to be tall and very handsome, though rather tlin : his manners are gentle and modest, and form 
a strong contrast to his conduct, which is equally exempt from the influence of shame, fear, and compassion.

There were many other chiefs at the court of Mahmood who enjoyed a less share of power derived from their birth or talents; or more frequently from favour and froth their tried attachment to the ruling party. In the licence of this reign, each of these was able to indulge his rapncity and satiate his private enmities without any restraint, except such as was imposed by the passions of his rivals. The utmost licentiousness prevailed among the soldiery, on whom the court relied; and, from the constant disturbances which lasted till Mahmood's deposition, his reign more resembled the temporary success of a military adventurer than the establishment of a regular government.

Mahmood's government was now fully established in the capital, but the provinces were as yet by no means under his authority.

Heraut had been given up to his brother Ferooz, who acknowledged Mahmood for King, but governed Heraut exactly as if he had been independent.

The north-eastern tribes still held out for Zemaun: The other provinces probably waited the final settlement of the dispute for the crown, without declaring for either party.

The principal opponent to Mahmood who now remained was Prince Shujah Ool Moolk, the full brother of Shauh Zemaun. This prince, then about twenty years of age, had beet left at Peshawer with a small party of guards. Shauh Zemaun's family, and almost all the jewels and other property of the crown, had been cominitted to his charge. After the first panic that followed his brother's defent, he took the resolution to proclaim himself $\mathbf{K i n g}$; and prepare for a regular contest with the usurper. He accordingly distributed large sums among the tribes round Peshawer, and soon saw the greater part of the Berdooraunees flock to his standard.

A considerable alarm appears to have prevailed at Maldmood's court in consequence of this step: his cause land 
already become unpopular from the general relaxation of all government, which left the bulk of the inhabitants of the country at the mercy of the courtiers and the soldiery; and a plot in favour of Shujah was discovered to have been entered on by Mookhtaur Oodowlah. That nobleman was, however, arrested, and the plot came to nothing.

On the 10th of September ${ }_{y}$ 1801, Sliujah Ool Moolk marched from Peshawer to attack Caubul. Abont half-way between those cities he found Mahmood's force, consisting of three thousand men, drawn up at Eshpaun, in a narrow plain surrounded with hills, and having the brook of Soorkhrood in their front. Shujah had at this time at least ten thousand men; but they were Berdooraunees, and though accustomed to the battles of their clans, they were strangers to discipline and to regular war. Shujah's arms were, however, victorious in the beginning of the battle; but his Berdooraunee troops, eager to profit by the confusion, quitted their line as soon as they thought the victory decided, and began to plunder the royal treasures, which Shujal had impruclently brought into the field. Futteh Khaun seized this opportunity, and charging at the head of his Baurikzyes, completed the confusion in Shujah's army. The battle was now decided, and Shujah escaped with some difficulty to the Khyber hills, where he remained till a fresh opportunity offered of asserting his claim to the throne.

The destruction of Shujah's army was far from restoring the quiet of the kingdom, for an insurrection now broke out which threatened to be fatal, not only to Mahmood's power, but to the existence of the Dooraunee government. The Ghiljies had remained in perfect tranquillity since the reign of Ahmed Shauh, and were now to appearance entirely reconciled to the Dooraunees : the descendants of their kings had been treated with kindness, and Abdooreheem, the representative of their royal family, enjoyed a pension from Shauh Zemaun, in addition to his paternal estates. The rest of the Ghiljies might still experience some injustice in common with the other tribes, but nothing done by the Dooraunees showed any remains of particular enmity to them. 
The ancient rivalry of the tribes was, however, still remembered by the Ghiljies, and the weakness of the Dooraunee government gave them a good opportunity of recovering their independence.

The rebellion was first planned at Caubul, where many of the Ghiljie chiefs happened to be. They offered the crown to Abdooreheem; who, though he had lately been injured by the government, was alarmed at the danger of an insurrection, and accepted their proposal with great reluctance. The chiefs then set off to prepare their tribes, and afterwards held other meetings, at which they settled the plan of their operations.

A force was appointed to check the Dooraunees of Candahar, and the rest of the troops were destined against Caubul. This last division moved first towards Ghuznee: they took several small places in their way, and defeated the governor of Ghuznee in the field; but the town held out, and the Ghiljies, after destroying the fields and orchards in the neighbourhood, advanced through Shilgur and Zoormul into Logur: many Ghiljies joined them on their march.

The Dooraunee government was so little on its guard against these preparations, that it was not till the advance of the Ghiljies to Ghuznce that the King received any information of their intention to rebel. It is impossible to describe the consternation which this unexpected event created at Caubul. The government was new, and the greater part of the kingdom unsettled: the few troops the King had were cletached to Peshawer, and none remained about his person but some Gholami Shauhs, and the retainers of the Dooraunee Khauns who were at court. The deficiency in numbers was, in some measure, compensated by the alacrity and unanimity, which the common danger produced; the Khauns, their relations, and even their menial servants, armed and offered to serve without pay. Such as could not procure arms, were equipped from the King's armoury; and a body was thus formed, amounting to three or four thousand men.

Mookhtar Oodowlah was released from confinement on this occasion, and the chief direction of the King's troops was 
intrusted to him. They set out from Caubul on the 12th of November, and took the way to Ghuznee, but soon learned that the rebels had passed that city, and were advancing through Logur upon Caubul. Or this the King's troops altered their course, and on their arrival at Sejawund they met the Ghiljie army. This body was at least twenty thousand strong, but was composed almost entirely of infantry, all illarmed, and some with no weapon but a club. It was under little control, and entirely devoid of every thing like order. The Dooraunees drew up in line in three divisions, with their camel swivels in front, and halted in this form to receive the Ghiljies, who rushed on in a confused mass, regardless of the fire that was lept up on them. When they had passed the camel-guus, they made a furious charge on the Dooraunee line: the division that was opposed to their column gave way, and the victory seemed to be decided in favour of the Ghiljies, till the unbroken part of the Dooraumees wheeling in on the flanks of the enemy, checked their progress, and forced them to attend to their own safety. The Ghiljies, though broken by this attack, were not dispersed, but retreated in a body to Killaee Zirreen, a fort of their own in the hills, about six miles from the field of battle. The Dooraunees followed them for part of the way, but not being able to make any impression on them, they gave up the pursuit.

The Ghiljies received reinforcements in the night; and early next morning they quitted Killaee Zirreen, and marched in the direction of Caubul, leaving the Dooraunees at some distance on their left. They reached Killaee Shauhee, within a few miles of Caubul, in the course of the evening, while the Dooraunees, having no intelligence, remained halted the whole of that day. Next morning they learned the movements of the Ghiljies, and marched in great haste and alarm to Killaee Ameen Ool Moolk, between the enemy's army and the city.

The Ghiljies, who had hitherto behaved with some regularity, now broke out into rapine and violence : they plundered the villages in their neighbourhood during the night, 
in contempt of Abdooreheem's endeavours to restrain them; and in the morning they marched out to attack the Dooraunees, without orders, and apparently without concert. They were entirely defeated with great slaughter; three thousand men are said to have been killed in the battle and pursuit, and the rest dispersed to their own districts. The Dooraunees then returned to Caubul, where they erected a pyramid of the heads of the enemy that had fallen in the battle.

The setting in of the winter prevented any farther hostilities at that time; but, early in the spring of 1802 , the Ghiljies rose as suddenly as before, and with more arrangernent: almost the whole of the Ghiljie clans were now engaged. Their force is said to have amounted to fifty thousand men.

It was determined that a body under Abdooreheem should attack Caubul from the south, and an equal body, under Futteh Khaun Babukurzye, from the east; while a force of ten thousand Ghiljies should keep the Dooraunees employed within their own boundaries. To each of these divisions a Dooraunee army was opposed, and three actions took place, all of which terminated in the entire success of the Dooraunees.

It is universally said (ancl the existence of the report, whether accurate or not, sliows the state of the country at the time,) that these three battles, the defeat of the Khyberees under Shauh Shujah, and a victory over the Uzbeks in Bulkh, took place on the same day in March, 1802.

After this struggle, part of the King's force was detached to ravage the Ghiljie country, and in the course of its operations it defeated a body of ten thousand Ghiljies at Moollah Shaudee, which was the last stand made by that tribe.

The severities of the government ceased with the campaign; and after tranquillity was restored, the Ghiljies experienced exactly the same treatment as before their rebellion.

It has already been mentioned that Prince Shujah sustained a defeat on the same day with the three great Ghiljie battles, that prince had advanced against Peshawer at the head of twelve thousand Khyberees, and was opposed by the 
regular troops of the city: a battle took place, in which the Khyberees were defeated with great slaughter; and the battle happening in summer, vast numbers perished from heat and thirst before they regained their mountains. Shujah, with difficulty, escaped to his former retreat.

The quiet of the kingdom was now entirely restored, but the government was left in a state of deplorable weakness: few of the provinces had been reduced; the Khaun of the Beloches, and many of the Afghaun tribes, refused to acknowledge so unsettled a government; and, as the treasury was empty, the King was destitute of the means of making a vigorous effort to restore the authority of the crown.

The Persians had profited by the distracted state of the monarchy, and had, in one campaign, almost completed the conquest of Persian Khorassaun. The last place they toak was Meshled, in which city Naudir Meerza, and thirty-eight other persons of Naudir Shauh's family, were taken prisoners, and carried to Teleraun, where they were all put to death, except one infant.

A son of Futteh Ali Shauln's was stationed at Meshed, as governor of Persian Khorassaun; and the conquest of that country by the Persians may be dated from this period, though Toorshish was not reduced till 1820, and Kelaut Naudiree, I believe, still holds out. Meshhed was taken in the summer of 1802 .

At the close of the Ghiljie war, and after the defeat of Sujah Ool Moalk, the court found itself freed from all immediate danger, and at leisure to take measures for reducing the rebellious provinces; but, as might be expected in such a government, the return of safety from without was accompanied by dissensions among the chiefs of the ruling party, and particularly between the two great leaders, Akram Khaun Alizye and Futteh Kliaun. The latter was, however, at length dispatched with a force to settle the south-east of the kingdom. He first proceeded to Peshawer, where he extorted money from the town, and received fifty thousand rupees from the chief of Cashmeer: he then marched to the 
south through Cohaut, Bunnoo, and Damaun, levying the revenue as be passed: lie spent a long time in endeavouring to reduce the Vizeerees, and after plundering their lands, he marched, settling the country as he passed, to Candahar, where he arrived in the summer of 1803.

Several important events had taken place in that quarter during his absence.

Shujah Ool Moolk had remained at Chora in the Afreedee country from the time of his defeat till Futteh Khaun's arrival at Peshawer. His former adherents still remained with him, and still treated him as King; but he seems himself to have given up all thoughts of any further struggle, and to have spent almost the whole of his time in reading and conversing with his military adherents, and some learned men, who had accompanied him in his retreat. The arrival of Futteh Khaun with such a force in Peshawer, rendered his residence at Chora unsafe, and he was compelled to retire further south, and take refuge among the mountains of the Caukers, where he continued to wander about, subsisting himself and his followers on the money which he occasionally obtained by the sale of his jewels, and by the casual hospitality of the people whose country he entered. $\mathrm{He}$ was in this condition in the depth of the winter of 1802, near the town of Shawl, or Quetta, in Belochistaun. He sent Meer Abool Hussun Khaun, and the Zubtbegee, into Shawl, to endeavour to sell some jewels; but in such a place no purchaser could well be expected: on their return they met the prince who, in his anxiety, had left his starving adherents; and rode out to meet them, and learn their success. He was in despair when he found they had failed, and immediately assembled his principal adherents, to consult on the course to be pursued. In this extremity, the Zubtbegee mentioned that a large caravan had that day entered Shawl, and, notwithstanding the prince's reluctance, it was soon resolved to plunder it. The prince's troops accordingly surrounded the town, and the merchants finding their retreat cut off, gave up their property, and received notes 
in the prince's name, promising to pay the value at a future time.*

This caravan was worth more than three lacs of rupees, and not only relieved the prince's present wants, but enabled him to assemble his troops for an attack on Candahar, in which he was to be assisted by Muddud Khaun, son of the former chief of that name. The attempt, however, failed for want of concert ; and Shujah was compelled to retire into the hills, where his army soon after dispersed.

In the mean time Mahmood's government was hastening to decay. The King's weakness and indolence had drawn universal contempt on his administration; his orders were disobeyed with impunity, and his officers scarcely possessed sufficient weight to maintain ardinary tranquillity in the capital.

The Gholami Shauhs (the King's Kuzzilbaush guards), who joined the violence of their military habits to the natural licentiousness of their nation, were guilty of the greatest excesses, and raised the utmost indignation among the inhabitants of Caubul, who were not more irritated by their rapacity and oppression, than disgusted with their contempt. for decency and sobriety, and their open profession of the Sheeah religion, which their prejudices led them to laok on with peculiar aversion.

These disorders were aggravated, and the discontents they occasioned were rendered formidable by the absence of Futteh Khaun, and the death of Akram Khaun, which deprived the King of his boldest and most powerful ministers.

Frequent complaints were made of the conduct of the Gholaums, but were disregarded by Mahmood, whose natural indolence was strengthened by his fondness for the manners which disgusted his subjects, and by the fear of offending those troops which he considered as the best support of his power. His partiality increased the discontents of his populace, and there were not wanting men of higher rank, who were disposed to foment their disaffection, and to profit by its effects. The: most prominent of these, at first, were

* He paid many of them niter his accession. 
Ahmed Khaun Noorzye, and Nawaub Khaun the lame, two noblemen of Ahmed Shauh's court, who affected the virtues and prejudices of the Dooraunees of former times; but the real mover of all the tumults which now ensued was Mookhtaur Oodowlah, a man well calculated to take the le adon such an occasion.

Under the mask of moderation, and even contempt for worldly honours, he concealed the highest ambition. He had long borne with impatience his exclusion from the office of vizeer, which he considered as his birth-right; and the government, aware of his high pretensions, were induced to withhold the honours and confidence which he had merited by his own great services. His qualities were such as were sure to gain popularity among his countrymen. His bravery was distinguished, and he possessed all the military accomplishments of his nation. He was entirely indifferent about money, except as an instrument of his ambition: he had the utmost contempt for pomp ; he even affected the dress and manners of a dervise, and this simplicity in a man of his known rank and reputation as a soldier and a statesman, seems to have greatly endeared him to the people. Even when he was vizeer, the meanest person had access to him, either in his house or when he went out, as he often did, unattended, and sometimes on foot. He scarcely ever refused a favour, and if he could not tire out his suitors by his patience and composure, his only resource was in promises, of which he made more than he ever cared to perform. He had great good nature and moderation towards his enemies, whom he not only forgave for past offences, but allowed to molest him with impunity when he had them in his power. These qualities captivated the generality of men, who did not sQ easily perceive his ambition, his want of principle, his fondness for intrigue, and his turn for art and dissimulation. He was singularly qualified for conducting an insurrection in which religion could be brought to share: he bad been obliged to fly to Belochistaun on the death of his father (the Vizeer Shauh Wullee Khaun), and had employed his banishment in study, so that he was now reckoned one of the most 
eminent Moollahs in the Afghaun dominions. He was more careless in the forms of devotion than Dooraunees generally are, but he had always affected, and probably felt, great zeal for the Soonnee religion. He was assiduous in paying court to men of learning and sanctity; and Syud Alımed, cominonly called the Meer Waez, who was eminent in both those characters, was his most confidential friend.

This man possessed great natural talents, and by frequent pilgrimages to Mecca, and by the purity, and even austerity of his life, had gained the highest reputation and influence in Caubul. His authority was strengthened by the freedom with which he preached against the vices of the court, the general corruption of manners, and the encouragement which was openly given to Sheealıs, agninst whom, in consistency with the prejudices of the people, he declaimed as blasphemers and infidels. The Meer Waez had already made himself conspicuous by a formal complaint to the King against the excesses of his guards, and may be considered as the avowed head of the mal-contents during the early stages of the insurrection.

The discontents of the people had risen to a great height, when an incident occurred which gave them an incitement and a pretence for open tumult. This was the execution of a young man of Caubul, for the murder of a Kuzzilbaush with whom he had quarrelled: the populace affected to cousider bis condemnation as dictated by Malumood's partiality to the Sheealss, and were marching to inter him with the honours of a maltyr, when the procession was fired on by a party of Kuzzilbaushes, and they were obliged to retire with the corpse to the house of the Meer Waez. This fresh outrage, raised the indignation of the populace to the highest pitch, and taking advantage of the absence of the Gholaums, who were in attendance on the King, they attacked the quarters of one of their divisions, which, after a short resistance, they forced and plundered.

The battle was renewed with grent fury on the next day; .numbers of the people of the country round Caubul, flocked in to assist the Soonnees; and many of the musketeers of the 
Cohistaun were led by a saint of their country to the aid of the same cause. Mookhtaur Oodowlah ancl other Dooraunee lords were now seen openly exciting the populace to fight for their religion, while the Meer Waez promised the joys of paradise to those who should fall, and sprinkled the leaders of the attack with the waters of the holy fountain of Zemzem,* which he had himself brought from Mecca. Both parties were, however, exhausted by the length of an unusually hot summer's day, and towards evening, an apparent reconciliation was brought about by the submission of the Persians. This tumult took place on the 4th and 5th of June. Botll parties were now desirous of a temporary suspension of operations : the King wished to wait for Futteh Khaun, who was on his march with an army from Candahar; and Mookhtaur Oodowlah for prince Sluujah, whom he had invited to set up for King. Mahmood's fears, however, precipitated affairs before he was prepared for the crisis; he thought his only safety lay in seizing Mookhtaur; and that nobleman, being apprized of his design, fled from Caubul on the 8th of July, after instructing the Meer Waez to renew the tumults in the city. This was done, and the rage of the populace was dexterously turned from the Sheeahs to the King, who patronized them. So effectual were these measures, that when Mookhtaur returned with Shujah Ool Moolk, on the 12th of July, he found Mahmood besieged in the Balla Hissaur, which was closely invested by the populace. Neither he nor the prince, however, entered Caubul ; both encamped without the town, and busied themselves in collecting troops to oppose Futteh Khaun, who now drew near with an army of eight or ten thousand men. An action took place soon after; Futteh Khaun was at first successful; he routed the part of the enemy which was immediately opposed to him, and was advancing to the city, when the desertion of a great lord to Shujah, threw the whole into confusion: his own party then fell off by degrees, till he found himself almost alone, and was obliged to provide for his safety by a precipitate flight.

* See Sule's Korran, Niebuhr's Arahii, \&c.

VOL. II. 
Next morning, Shauh Shujal entered Caubul in triumpl. Mookhtaur Oodowlah walked on foot by the side of his horse, and many other Dooraunee Ameers followed in his train. To keep up the impression of the triumph of the true faith, the heralds who preceded the King were ordered to announce his approach by the watchword of the Soonnee sect* instead of the Toorkee form, which is required by the practice of the court.

The gates of the Balla Hissaur were thrown open on the King's approach; and Mahmood, deserted by all his adherents, suffered himself to be quietly conducted to the upper. fort, where the princes of the blood are confined. His eyes were spared, but Slujah ins unfortunately load sufficient reason to regret this clemeney, of which he probably afforded the first eximple in his country.

I'his revolution, though it at the time improved the state of affairs, was not calculated to restore the power of the crown, or the importance of the state. The new King, though his good qualities were amply sufficient to maintain the dignity of an established monarch, was deficient in the genius and encrgy which were requisite to restore a government so far sumk into anarchy and clecay.

From what has been said of Mahmood's reign, it may be imagined that the great men were become powerful and unruly, that the army was impatient of discipline, that the government had, in a great measure, lost the attachment of its suljects, and that botli the remote provinces and the neighbouring powers had changed the awe with which they were used to view the Dooraumees for a feeling of indifference bordering on contempt. Some circumstances in Shauh Shujah's situation added to his embarrassments, and prevented the government recovering its vigour. The King had been for two years a fugitive in his own dominions, cluring which time he had made severnl attempts to expel his rival. He had consequently incurrel great obligations to the Dooraunees and other chiefs. These were rendered of the more import-

\footnotetext{
- Dumi char yaur, ("the life of the four friencls,") an allusion to the first
} four Caliphs, three of whom ure considered as usurpers by the Slreenhs. 
ance by his own disposition, which was susceptible of gratitude and permanent attachment. His recall by Mookhtaur Oodowlah and his party brought a fresh set of claimants on him, whose services he could not deny, and whose power he was obliged to respect. The consequencc was, that all the honours and appointments in the gift of the crown were insufficient to reward the King's adherents, and he was obliged to give away a large portion of bis permanent revenue in grants to such as remained unprovided for: thus, almost the whole revenue of Peshawer was settled on the Khyberees as the reward of their attachment, and much of the royal dues were alienated in otler places, in favour of Dooraunee chiefs. What remained of the revenue passed through the hands of the vizeer, who, as soon as his interests were separated from those of the King, applied a large po:tion of the public money to his own use.

Had the King given his confidence entirely to the vizeer, many of the inconveniences which were afterwards felt might have been avoided. It would have been the interest of that minister to raise the King's power; and lis success in the beginning of Shujah's reign, showed that he had the talents and influence requisite for such an undertaking. 'This plan, however, was not tried. The King was not disposed to resign his own power into the hands of his minister; and his old adherents, who were anxious to succeed to their share of power, early inspired him with jealousy of the vizeer, and induced him to adopt a system of counteraction to his measures; the want of harmony between the King and his minister prevented any vigorous exertion against their common enemy, and obliged each to lavish the resources of the state in securing partizans to himself.

In consequence of this weakness of the government, every nobleman who was discontented with the court had it in his power to raise a rebeilion, and to shelter himself, if he failed, either in the midst of his own tribe, or in some part of the country not easily within reach of the King. Nor was it difficult for him to procure a pardon, if he wished to be reconciled to the Court; for the state of the King's affairis 
rendered it more necessary for the support of his authority to conciliate friends than to punish enemies. This certainty of impunity gave a peculiar character to the rebellions of this reign, which were raised on the most trifling grounds, and conducted with the utmost levity. The slightest provocation from the court druve a nobleman into rebellion; the slightest offence from one of the rebels sent him back to the court, or led him to set up a new party; and the whole had more the appearance of a game anong children than of a civil war.

The jealousies between the King and the vizeer did not, however, show themselves till some time after Shujah's accession, and the beginning of his reign was quiet and prosperous.

The irst step he took was to release his brother Shauh Zemaun; and suon after Moollah Ashik, who had betrayed Zemaum, was apprehended, and suffered the punishment of his perfidy and ingratitude. This was the only execution that followed the change of government. All the other measures of Mookhtaur Oodowlah's internal administration were calculated to conciliate, and to efface the memory of the civil dissensions which had so long prevailed. At the same time he applied himself with great vigour and success to reduce the rebelious provinces, and to bring the empire into its ancient state.

The tirst expedition was sent to Candahar, which was still lield by Prince Caumraun and Futtel Khaun. The place was taken without difficulty, and what was of greater importance, Futteh Khaun was soon after persuaded to make his submissions to the new King. An opportunity was now offered of securing the attachment of this powerful and active chief: but it was allowed to escape, and hence arose the misfortunes which disturbed the rest of Shauh Shujah's reign, and which drove him at length from his throne. Futtel Khaun's demands from the court were moderate, and did not extend beyond the offices held by his father; but these were withheld, owing either to the imprudence of the King, or the jealousy of the vizeer; and Futteh Khaun, after a short residence at the court, quitted it in disgust, and retired to his castle at Girishk. 
The effects of his disaffection were early and severely felt; for in January, 1804, when the King had assembled an army of thirty thousand men at Peshawer, and was on the point of completing the settlement of his dominions, by intimidating the chiefs of Cashmeer and Sind, he rcceived intelligence of a rebellion at Candahar, which obliged him immediately to relinquish his design. The rise and progress of this transaction will serve to illustrate what has been said of the levity and inconsistency which distinguish the late Afghaun civil wars. The government of Candahar had been given to Prince Kyser (a son of Shauh Zemaun's), under the guidance of Ahmed Khaun Noorzye, whose desertion of Shauh Zemaun had been effaced by his zeal for the Soonnee religion. Futteh Khaun found means to persuade the young prince to imprison Ahmed Khaun, and endeavour to make himself King. Ahmed Khaun was accordingly seized, but, though he was treated with many insults and severities, and had been chained with the chains of an elephant, in derision of his gigantic stature, yet, as soon as the prince and Futteh Khatun were prepared to move out against Caubul, they released him, and entrusted him with the defence of the city.

The consequences night have beell expected; Alımed Khaun's son went over to Shujah, and occasioned the defeat of Kyser, while he himself, indifferent who was King, if he could be but revenged on Kyser, gave up Candahar to Cauıraun, whom he invited from Furrah to occupy it. After the defeat of Kyser's army, the King was about to enter once more on the settlement of his eastern clominions, when he learned that Kyser and Futteh Khaun had recovered Candahar, and were again assembling troops. He then returned towards Candahar, which was evacuated on his approach; and Kyser soon after threw himself on the King's mercy, was affectionately received, and was reinstated in his government. Futteh Khaun, finding his schenes at Candahar defeated, repaired to Heraut, and insinuating himself into the confidence of Prince Teerooz, persuaded him to assert his claim to the throne of Caubul. Feerooz appearing in arms, Shujah sent Kyser at the head of an army to oppose him, and at the 
same time offered terms, which Feerooz, who was naturaily cautious, thought proper to accept, while Futtel quitted him in indigrıation, and again retired to Girishk.

The whole of the west being now settled, the King and the vizeer set out from Candahar in the end of September, and marching first to Sind, they compelled the chiefs of that country to acknowledge the new government, and to pay scventeen lacs of rupees; after which the King moved up his eastern frontier, and settled all the provinces in his route. He renched Peshawer in April 1805, and soon after received an ambassador from the King of Bokhaura, who came to propose a renewal of the alliance concluded by Zemaun, and to negotiate the double marriage of Shujah to the daughter of the King of Boklaura, and of that King to a princess of Caubul. The ambassador was favourably received; but as it is contrary to the Dooraunee custom to give their daughters in marriage to foreigners, the part of the proposal respecting the King of Bolihaura's marriage was civilly declined : that of Shujah was nevertheless ayreed to.

During all this time Kyser continued to serve the King witl zeal and fidelity in the government of Candahar; he had even contrived to seize Futteh Khaun, and had nearly been persunded to gratify the revenge of his father, Shauh Zemaun, by putting him to death; but Futteh Khaun, laving prevailed on the prince to visit him privately in prison, so far won on him by his insinuating manners, his allusions to former services, and his promises of future attachment, that Kyser not only set him free, but resumed his old connection with him, and began once more to aspire to the throne. Futteh Khaun, on his release, repaired to Girishk, where he began preparations for the intended enterprize ; but, on his return to Candahar, he found Kyser under the influence of Khojeh Mabommed Khaun, another great nobleman, who had dissuaded him from his design of rebelling. On this, Futteh Kuaun, equally incensed at the derangement of his plans, and at the preference of another's advice to his, openly renounced all connection with Kyser, and engaged to deliver up Candahar to Caumraun, whom he 
invited to occupy it. Caumraun, who was at this time at Furrah, immediately assembled a body of troops, and advanced to Eeclgauh, a few miles from Candahar, and Kyser was about to quit the city, when a scene ensued, which is scarcely credible even to persons acquainted with the eccentricity of Futteh Khaun's character, and the sudden changes of affairs so common among Dooraunees. On the night before Kyser's flight, he desired to have a parting interview with Futteh Khaun; and this meeting took place by torch light on an open terrace in the market-place, which, with the surrounding streets, was filled with horsemen ready for a march. The conference began with mutual reproaches; but the prince, gradually softening his tone, reminded Futteh Khaun of his having saved his life, and besought him not to repay his benefits by driving him into exile. Futteh Khaun then recapitulated his designs in favour of Kyser, aud complained of the neglect with which his advice was treated: on this Kyser assured lim that he was ready for ever after to follow his counsels implicitly, and strengthened his assertions by such solernn oaths, that Futteh Khaun was shaken, and at last dismissed his resentment, and swore to support the prince in all extremities. Next morning the prince and Futteh moved out together to oppose Caumraun. Futteh $\mathrm{K}$ haun advanced with his own division, and calling out to Caumraun, acquainted him with the change in his sentiments, and endeavoured to persuade him to retire. Caumraun was at first astonished at this revolution, but he resumed his courage, and answered in terms of defiance ; on which Futteh Khaun, without waiting for the other troops, charged the prince sword in hand; and such was the effect of this unexpected attack, that Caumraun's troops broke, and he himself with difficulty effected his escape to Furrah.

Futteh Khaun's plan of placing Kyser on the throne was now resumed, apparently with that prince's full concurrence; but its execution was artfully delayed by Khojeh Mahommed, who left no means of operating on the passions, the prudence, and even on the superstition of the conspirators, unpractised to defeat the scheme. 
Meanwhile the King had prepared an expedition at Peshawer for the purpose of reducing Cashmeer, the only province that remained in rebellion. Abdoollah Khaun, the governor, had fomented the troubles at Candahar with the view of cliverting the attack on himself; and though that diversion was now at an end, Abdoollah was saved for the present by the dissensions which prevailed among Shujah's own courtiers. The insinuations of Akram Khaun indnced the King to refuse the command of the army to the vizeer, and even to talk of assuming it himself. On this the vizeer discouraged the expedition altogether, and found means to put off the march of the troops till a subsequent period, when the King's views were more accommodated to his own. This opportunity offered at Caubul, and the vizeer was about to commence his march when Akram Khaun prevailed on the King to call on him to pay a sum of money as the condition on which he should have the command. The King accordingly required three lacs of rupees; but about this time the vizeer lost his favourite daughter, and was so much affected, that he declared he was resolved never to quit her grave, or to take any further concern in worldly affairs. 'The King was now reduced to solicit him to resume his office, and carry on the war against Cashmeer. He consented with real or assumed reluctance, and the claim for money was no longer mentioned.

At length he set out on his march with an army of ten thousand men. The first opposition lie encountered was at Mozufferabad, where he found the high and rocky bank of a rapid branch of the Hydaspes occupied by the Cashmerian army : he nevertheless effected a passage in four divisions, and drove the enemy from their ground. One of his own sons was wounded in this engagement. The rest of the road to Cashmeer was through steep and barren mountains, and often along the face of precipices. The vizeer's advance was consequently slow, and his provisions began to fail him long before he reached the valley. The vizeer, however, encouraged his men by sharing their sufferings; he gave up his own store to the soldiers, and is said to have suffered the 
extremities of hunger before he was able to procure relief for his army. So great was the distress of his troops, that when he came to a defile beyond which the enemy's army was encamped, he was not able to hold out till he tried the chance of a battle, which might bave removed all his embarrassments. He therefore began to treat with Abdoollah Khaun : he told him his difficulties without reserve : and Abdoollah, unwilling to drive him to desperation, listened to the terms which were offered, and agreed to supply him with provisions. Mookhtaur prolonged a delusive negotiation till he had secured some further advantages which he had in view; he then threw off the mask, and hostilities were immediately renewed.

The armies, however, were still separated by the Hydaspes. At last Abdoollah threw a bridge over the river in the night, and crossing it witlout delay, appeared on the vizeer's rear when he was entirely unprepared to oppose him; the greater part of his troops were out foraging, and he could not collect above a hundred horse when he first moved out against the enemy. By degrees, however, the whole army was assembled, and was advancing with the vizeer at its hend, when a party which he had sent in front fell back on them in the greatest confusion. They had been routed in consequence of the cowardice of the vizeer's son Atta Mahommed, who fled without striking a blow, and was followed by his disheartened troops. This example lad nearly ruined the army, but its courage was restored by the firmness of the vizeer, who received the broken troops with great serenity. attributed his son's flight to a concerted feint, and advanced with increased rapidity, as if to take advantage of the success of his stratagem. This onset had a very different issue from the former; for, after an obstinate conflict, in which the vizeer's courage was conspicuous, the Cashmeer army was routed and driven back on the river. The bridge was choked by the crowds of fugitives: great part of the army, among which was Abdoollah Khaun, were forced to swim, and many were cut to pieces by the victors or drowned in the river. 
Abdoollah Khatan now took refuge in lis fort, where he had made every preparation for a long siege; and the King's troops were prevented by the season and by the fatigues which they had suffered from attempting any operation during the rest of the winter.

Early in the spring the fort was attacked, and had held out for two months, when Abdoollah Khaun died. He was a man of good talents and great courage. $\mathrm{He}$ is still spoken of with affection by the Cashmerians, and by the Dooraunees who have served under him. He is commended for his love of justice and his skill in administering it; for his liberality, his affable manners, and his princely mngnificence. He was also a great encourager of learning and poetry. Perhaps no Dooraunee has left a character so generally admired.

The fort was defended for two months after his death, when it surrendered on condition that Abdoollab Khaun's family and the chiefs in the fort should be allowed to reside unmolested either at Caubul or Peshawer. These terms were strictly observed, and Cashmeer was now completely reduced under the King's authority.

The vizeer remained in Cashmeer for some montls after the reduction of the province; but it is now necessary to turn to the events which took place in the west cluring the period of this long campaign.

The reconciliation between Futteh Khaun and Kyser was of no long duration: Khojeh Mahommed retained his ascendancy : and Futteh Khaun retired to Girishk, and once more renewed his intrigues with Caumraun.

It might have been expected that this prince would have been slow to embark in any enterprize with a person who had so lately deceived him; but Caumraun, brought up amidst revolutions, and accustomed to put every thing to hazard, had no hesitation in entering on the project held out to him. He joined Futteh Khaun, and, as they advanced towards Candahar, they were met by part of the garrison, while Kyser fled into the country of the Beloches, where he waited for reinforcements from the King.

'The King was at Peshawer when the news of this mis- 
fortune reached him. He sent without delay to recall the vizeer from Caslumeer ; but that minister was unable or unwilling to join him, and he was obliged to command in person against the rebels.

Before he reached Candahar, his troops had been again defeated by Caumraun, who was reinforced by a body of six thousand men from Heraut, uncler the command of Mullik Caussim, the son of Prince Feerooz.

That force was, however, soon recalled to Heraut by an attack of the Persians; Caumraun Hed, the King entered Canclahar unopposed, and Futteh Khaun was soon after prevailed on to join him.

The attack of the Persians which recalled Mullik Caussim, had been brought on by an offensive operation of Feerooz Oodeen, and had been for some time threatened; yet so secure was Feerooz, that he sent his best troops to the assistance of Caumraun, and made no preparations for his own defence till the Persians were assernbled in grent force within a short distance of his city. He then found his force confined to seven liundred Dooraunees and two thousand Persian guards; but he was soon joined by five or six thousand Fimauks, who were raised to great enthusiasm against the Persians and Sheeahs by the exhortations of Soofee Islaum, and Uzbel Moollah, who had long resided at Heraut, where lie enjoyed great wealth and honour.

With this army Feerooz marched out to engage the Persians, who were superior in numbers as well as in the character of their troops; instead of defending the passage of the Pooleemaulaun (Ochus), he injudiciously left that river in his rear ; and no sooner had his army crossed, than the Persians sent a body of excellent infantry to occupy the only bridge. Nevertheless the seven hundred Dooramees charged the enemy with the utmost impetuosity: they broke through the first line of the Persians, which was composed of infantry, and threw the centre of the cavalry, who formed the second line, into great confusion; but being greatly outnumbered, thcy were soon surrounded and cut off almost to a man. The Eimauks broke as soon as the Dooraunees were sur- 
rounded, and Feerooz fled without making any exertion. The slaughter was great: Soofee Islaum fell fighting gallantly at the head of a band composed of his own retainers, and of religious enthusiasts who accompanied him as volunteers. His body fell into the hands of the Persians, who burned it with every circumstance of indignity. The fugitives fared little better: many were drowned in the Ochus, and Feerooz himself escaped with great difficulty, after losing his horse.

The Persians immediately prepared to lay siege to Heraut; but Mullik Caussim was now on his return; the Eimauks and Dooraunees had time to assemble; and the Persians proposed terms to Feerooz, which that cautious prince accepted. They were, that he should pay 50,000 rupees, and give his son as a hostage for the discharge of the sum, and that he should give his daughter in marriage to the Persian prince at Meshed : the first two articles were fulfilled, but the third was disregarded.

This success of the Persians at first excited a strong sensation among the Dooraunees, and the King at one time intended to have moved to Heraut in person to vindicate the honour of the Afghaun name; but the internal state of the kingdom at this time was by no means such as to allow of for eign enterprizes.

The chief obstacle arose from the increased disunion between the King and the vizeer, which was now rapidly tending to an open rupture. Whatever jealousy the King might have entertained of the vizeer's power, he had hitherto been led to respect him by a sense of clependence on his influence and abilities; but he liad now been left to quell a serious rebellion without the advice or assistance of his minister: the success he had met with encouraged him to place greater reliance on his own resources, and at last to oppose the vizeer's wishes, and to treat his advice with contempt.

The vizeer's disaffection augmented in proportion as his influence declined, and it has been suspected that lie was the author of an attempt which took place at this time to raise Alsbass, one of the confined princes, to the throne. The plan 
failed, but was not without serious consequences, as Mahmood effected his escape during the confusion which it occasioned.

Not long after the vizeer arrived from Cashmeer: he learned that the King resolved to proceed from Candahar to Sind, a step from which he used all his influence to dissuade him; and having now ascertained that his power over his master was gone, he resolved to lose no time in placing a more compliant prince upon the throne. He accordingly halted at Caubul, and entered into a strict connection with Prince Kyser, whom he persuaded to enter into his design.

In the mean time the King proceeded to Sind, and entered into an arrangement with the governors, which gave so much offence to their determined enemy, Futteh Khaun, that he took the earliest opportunity of quitting the army with the three thousand troops under his command.

During these transactions, and probably before Futtel Khaun's flight, the King received intelligence that the vizeer - had proclained Prince Kyser King at Caubul; and not long after he learned that the city of Peshawer had fallen into the hands of the rebels. He resolved to direct his first operations against that city, and he succeeded in recovering it by the end of February.

About the same time the vizeer and Kyser arrived in the neighbourhood with a force amounting to twelve thousand men, and after a fruitless negotiation the parties engaged on the $3 \mathrm{~d}$ of March 1808.

The royal troops were broken at the first onset, and the King himself was about to quit the field, when the vizeer, carried on by his natural courage, and by the near prospect of success, imprudently charged him at the head of a handful of men. The Khauns about the King made a desperate resistance, and the vizeer was shot in the struggle. The King's troops rallied on this event, and the fate of the battle was soon turned in their favour.

The King entered Peshawer in triumph; the vizeer's head was borne behind him on a spear.

This victory entirely restored the King's affairs in Pesha- 
wer, but Cashmeer still held out for the vizeer's party, under his son, Atta Mahommed Khaun; and the King was prevented undertaking any thing in that province by the more urgent difficulties which subsisted in Cauljul and Candahar.

The Meer Waez, who had remained at Caubul while the vizeer marched for Peshawer, no sooner heard of the defeat and death of his friend, than he set all the imprisoned princes at liberty, and prepared for a vigorous defence of the capital. He was obliged to desert the city on the King's approach ; but he retired with Kyser into the strong country of the Cohistaun, where he continued for some time to resist the troops which were sent against him. At lengtl Kyser was persuaded to come in, and was freely pardoned, and the King marched against Mahmood, who had been joined by Futtel Khaun, and had taken Candahar. The rivals met on the east of that city, Mahmood was defeated, and Candahar fell into the hands of the victor.

The King was now about to move towards Sind, but being anticipated by a payment from that province he set out for . Peshawer, which place he reached on the 10th of January, 1809.

The Caubul mission arrived at Peshawer soon after this, and the succeeding events are related in the narrative of its proceedings.

[After the flight of Shujah, Futteh Khaun ruled according to his own pleasure under the authority of Mahmood. He recovered Cashmeer by the aid of Runjeet Sing, and afterwards quarrelled with that chief, and was defeated by him near the Indus. He took Heraut by treachery from Haji Feerooz, and repulsed an attack made on that city by the Persians; but in 1818, after an administration of eight years, he fell a victim to the jealousy of Caumraun, the envy of the other nobles, and the ingratitude of Mahmood. His death was the signal of the breaking up of the monarchy. His brothers revolted at the head of their tribe and partisans, and Mahmood's authority was at once confined to Herauti and its dependencies. 
[Caubul, Candahar, and Peshawer, with the districts round those cities, were held by different brothers, who soon fell out among themselves. The Dooraunees paid a partial obedience to the rulers of Candahar or Heraut, according to the situation of their lands. The other tribes remained independent.

[During the lecay of the Dooraunee monarchy Runjeet Sing was perfecting the discipline of his army by means of European officers. This circumstance, which would have made him formidable to the Indian possessions of the Afghauns, even if that nation had been united, rendered him irresistible to their distracted government and denuded frontier. He took Cashmeer, Moultaun, Leia, Upper Sind, and the nearest part of Damaun; reduced the tribes soutl of Cashmeer into dependence; and he subsequently took advantage of a quarrel between the chief of Caubul and his brother at Peshawer, accompanied by a successful expedition of Shauh Shujalı against Candahar, to make a conquest of Peshawer itself, and all the plain country to the Indus.

[The Ameers of Sind also scized on Slikarpoor; Bullih threw off its nominal dependence; and the Prince of Belochistaun retained his in name only.

[Dost Mahommed, the Sirdar of Caubul, has the repulation of a just and enlightened ruler. Both lie and lis laalfbrother at Candahar are inimical to Caumraun, who has succeeded, by his father's death, to the possession of Ileraut and the claims of the house of Suddozye.

[The city of Peshawer has suffered greatly during these wars and revolutions, but there does not appear to be any decline in the rest of the country.

[Besides the expeclition in which lie gained temporary possession of Candahar, Shauh Shujalı has been engaged in other enterprizes in different parts of his clominions, but is now again an exile at the British station of Lodceana. In the interval he has gone through many romantic adventures, of which he has written a narrative. He was at one time perfidiously seized and barbarously treated by Runjeet Sing, whose object was to extort from him the farnous diamond called the Cohi Noor. These events, and his deliverance by 
the spirit and talents of his Queen, form an interesting portion of the summary of recent events in Afghaunistaun by Sir A. Burnes, from which, and the fuller narrative of $\mathrm{Mr}$. Conolly, the substance of this note has been extracted.

[The most natural consequence of all these misfortunes would have been the subjugation of the Afghaun part of Khorassaun by Persia, but although repeated attempts have been made to take Heraut, and though the King of Persia has a regular army disciplined by European officers, no impression has yet been made in that quarter. Caumraun himself seems to rival his father in feebleness and debauchery, but his power is upheld by the vigour and courage of Yaur Mahommed Khaun, his vizeer. It has never yet been exposed to so great a hazard as at this moment. * * * * *

$$
\text { * * * * * * * * * * * * * * }
$$

It is now a year since Heraut has been besieged by the King of Persia, and although by the last accounts he had just failed, with heavy loss, $\dagger$ in an attempt to storm; yet if the chiefs of Candahar and Caubul should be induced to join the common enemy, it is possible that his perseverance may still be rewarded by the conquest of the bulwark of the Dooraunee country. Such an event would produce a serions change in the prospects of our Indian empire, and might possibly not be without influence on the politics of Europe. -October, 1838.]

[† The loss is strted to be 11 colonels, 45 officers, and 3750 disciplined soldiers.] 


\title{
APPENDIX B.
}

\author{
MR. DURIE'S NARRATIVE.
}

"In the evening arrived at the stone Mehmaun seroy," which has a good deal of Persian verses inscribed all about it;-proceeded thence to Attuck, situated a little way off from it on the top of pretty high mountains, below which the river flows down with great rapidity and noise. Not being permitted to get in by the gate, I went to the village on the lefthand side, where upwards of twenty Pytans were seated on cots (couches) in the chokee (guard-room), having a flag fixed: they had two or three culleeauns, and were smoking tobacco and talking. Having sullamed, I went and sat, and smoked also. They inquiring whence I came, I told them from Bengal, and was going on a pilgrimage to Bagdad Shurreef and Mecca Mobaruck. On being told that $I$ had been in the English service, one of them, well dressed with a gown and a good reddish-coloured turban, talked curiously about the battle of Rampore; saying, the English not having fired, they were cut off to a great amount; but when only a few remained, they began to fire; upon which the Rohillas were driven back, killed, and their countries entirely taken.

* I have before inentioned (vol.i. p.269,) that Mr. Durie wrote a narrative of his journey, and that $I$ also asked him questions and took notes of lis replies. The following is his rarrative, and the purt within inverted commas is in his own langunge, except that I have rltered the grummar, and sometimes the words, where the sense was obscured by the mistakes whicl $\mathrm{Mr}$. Durie nade in consequence of the hurry with which this was composed. I have not, however, altered much in this way, and the part between commas may be reckoned entirely Mr. Durie's own. Tae parts where Mr. Durie is mentioned in the third person nre eitles abstracted from his uarrative, or taken from my notes above alluded to ; even there $M_{r}$. Durie's language is generally preserved.

VOL. II. 
About candlelight almost all of them got out with their cots upon the open plain; about eight, one of them observing I was hungry, got me some bread, asking why I had not. mentioned it in time, and he would have got me some stuff with my bread. In the morning crossed the river, having much trouble to cross, owing to the great rapidity of the river."

Mr. Durie then proceeded in four days' journey to Peshawer, picking up occasional companions on the road, stopping to smoke in the villages he passed through, and getting food, sometimes from the villagers, and sometimes from other travellers. At Peshawer the people complained of the depredations of the Dooraunees and of the King's followers. Mr. Durie had hitherto travelled without any money, but at $\mathrm{Pe}$ shawer a barber and some others collected some copper money for him, and be set off with a caravan for Caubul. "The next day got some of my money taken slyly from me by some boys, who came about me clapping me on the shoulder while I was smoking." "On the same day a boy belonging to some Dooraunee was robbed by the villagers, and the Dooraunees contented themselves with causing restitution to be made. He proceeded through the Khyber valley, the caravan being often stopped and harassed for fees by the Khyberees. "One evening the caravan was stopped by an old Afghaun with a small stick in his hand; being vexed, I went up to him, and exerted myself to take his stick; he pelted me hard with stones, and upwards of thirty came out from the surrounding mountains. I got off, however; they let us proceed after some disputation. The route went all the way to Lallpora, on the river up and down. Had much conversation with several of the caravan concerning Europeans and the embassy; they praising them very much, and holding them to be in every respect very wise, intelligent, and equitable.". He was now turned out of the caravan for not being able to pay his fees, but he joined some pilgrims, who treated him kindly, and gave him bread and fruit. They also picked up a Persian fellow-traveller, "who was very entertaining in his discourse and in chaunting of odes." In this way he went on to 
Caubul, which he reached in fourteen days from Peshawer; most of his fellow-travellers took him for a person of Uzbek descent. They once found out he was not circumcised, and one of the pilgrims offered to perform that ceremony for him if he chose. Mr. Durie declined, and said he would get it clone at Caubul. "There is no fear for a Christian in the towns, nor when you are on the road after you get to a Khyle, but while you are travelling, some ignorant people might treat you ill."

On entering Caubul he went to a place belonging to some Fakeers, and helped one of them to draw water till the others told him to stop, as he was tired. "The head Fakeer called in the evening, and the young man called Aushuk Shauh, carried me to a person who gave me a loaf. Fronting the Takeea* stands the King's palace, with three minarets with gilt tops, and a pretty spacious hall with several columns. These are in the Ballasur, which is situated on hilly ground, and has a wall communicating from this side to the other, whicl leads across to the shore bazar of the town, where bakers, coolss, soup-sellers, fruit, green, or $\uparrow$ falonda sellers, Hindoo shopkeepers, and fine shoe and boot sellers reside. 'Toward the west from these bazars are passages leading to very high Hindoo houses, having much wood work, and to other square places, having joined apartments two stories high for merchants to resort to. From the Lahoree gate, one road leads to these shore bazars (the shops having artificers of different denominations, much the same as at Peshour,) to Bala choak, where the greater Hindoo and Malommedan cloth merchants dwell in joined shops on both sides, with a covered roof : having gone through these we get to a square, where there are many two-story high buildings; in the lower rooms of them, be artificers and sellers of different kinds. This square leads by two or three passages to other bazars and shops. Going to the bazars, passengers and others, observing me to be a traveller, gave me pice (copper money), or bread, so that I got enough of bread, soup, fire, fruit, and falooda, which last consists of cream, syrup, and snow, of most cool and pleasant

* This name is given to the residence of Fakeers. t Sec Note; vol. i. page 336. 
taste. One day I went up to the top of an enormous high mountain to an entertainment given and exhibited by Fakeers; great numbers of the people went. The roads leacling to these mountains were very excellent, having here and there very fine places to sit; consequently people sat here and there discoursing and viewing the town below, having a very great number of fine gardens, the houses being neatly and cleanly plastered with mud, two or three stories high; but the Hindoo houses are much more high, and greatly consisting of woodwork. Around, within the innumerable mountains in the pleasant vales, are Killas of moderate size, inluabited by the Afghauns. In the town the inhabitants are of different kinds; the proper inhabitant is white enough, the clime being extremely cold; the $\Lambda$ fghauns below Caubul are black, swarthy, yellow, or whitish ; but beyond, proceeding towards Candahar, they are all fairer, but by no means white : from Caubul towarls Bullil, white; and from Candahar towards Heraut, white; and towards Shecarpore, Deyra, \&c. swarthy. 'They are all Mahommedans, but the stuff and grain shops, also the greatest part of the cloth shops, are held by Hindoos. On the south and west sicle of the town is a river, not deep, in which direction a very narrow river rushes along, near Caubul, between vast mountains, the passage between on both sides most magnificently adorned with large and small fruit trees of all sorts, and fields of green. At distances are situated very good sets of Killahs. Passed the time, twenty days, very agreeally at the Fakeer's place, where people of different denominations constantly attended, smoking churse or tobacco, conformably to their respective desires, and discoursed agreeably on various subjects; often concerning the Europeans, whom they reckon as very intelligent, and very admirable and good in their manners, though in many respects as misled. A baker came from India, who had been in the English employ, but, as he said, having once been berten, he had left, and was going to Bagdad : he asserted there before the company, which was pretty numerous, that he had heard many Dooraunees and other Moguls declare that the Europeans were as good Mussulmauns as themselves, but he reckoned them, and he would have all others to reckon them, as inficlels. 
Many persons used to come and smoke at the Takeea, and Mr. Durie used to sit and talk with them: some discovered that he was not a Mussulnaun, but did not molest him on that account. In towns they often suspected him of being a spy, and some respectable people told him not to give information about their place when he went back to his own country.

"The head Fakeer requested of me to tarry at his place throughout the cold, and he would get me a poosteen aud other clothes; however, I left the place without giving previous notice, and arriving at the gate which led to Candahar, got some tobacco, and going out, saw some tents of some respectable travellers who were proceeding on a pilgrimage. As they were to tarry a few days I went off; an Afghaun accompanied me to Killa. Cazee, requesting I would pray for him on my arrival at Bagdad. On reaching Killa Cazee he sent me some bread, and I went in the clark to a mosque; a Moollah who was there gave me some bread and butter-milk.

"The next day in the evening arrived at Moydan, went up to a Killa; ; or a raised ground; saw several Afghauns seated, called for a culleeaun; they produced it. One of them being sick, requested I would prescribe something for him: I told him I could not, as I was ignorant of the names of medicines in the country. When candle-light took place, went to a mosque, where they were engaged in prayer. Having done, there was rice and buttermilk in wooden bowls, and wooden spoons, brought; they gave some to me, also to some other travellers who had arrived there. The next day before twelve arrived at a place where I saw two or three Dooraunees with their horses. They gave me to smoke, and dissuaded me from going alone, saying, the Afghauns were very wicked, and t would cut my head off, or carry me to slavery, even for nothing. A Fakeer, going on crutches, happened to come there with intention of going to Bagdad and Mecca with two lads. I told them I was, going also; they were glad, and desired me to follow them; there was another sick man with them going to a village not far off.

* A fort or castle.

+ 'These are the predatory Ghijfies mentioned in prge 128, vol. ii. 
We proceeded together to a set of Killas, arrived when it became dark, and with some difficulty obtained bread and rice. The next day a man came up to us, and compelled the youngest of the two lads (by whose sister he had been sent) to return to town along with him. Proceeding about evening, the sick man left us; arrived at a set of Killas belonging to Vurduck Afghauns. Alighted under a shade of newly planted trees. The lame Fakeer, accompanied by the young man, went into three or four Killas, and with very sonorous calls demanded bread, which he plentifully obtained. He wanted tobacco, and several of them saying they had none, he spoke roughly enough to them. The next day tarried there under. the shade of the trees. At twelve in the evening the lame Fakeer visited the Killas with sonorous calls, and got plenty. 'The next day in our way, the culleeaun we lad, happened to be broke; through good luck, it was the lame Fakeer's fault: on arrival at another set of Killas he loudly asked for a culleeaun, which they could not give, and he spoke roughly to them, and was getting ready to leave them, when some civilly desired hin to wait a little, and he should hove ment and bread. In the evening a large bowl of very good soup, with two pieces of bread and two pieces of meat for each of us, was produced. The next day arrived at another set of Killas; the Fakecr forced them with his noise to give him a culleeaun, tobacco, and bread. The next day, at some Killas, some Moollalıs came up to us and talked on various religious subjects, and through much request obtained of the young man a small Persian book on prayer, giving some copper money and some flour for it. At night, sleeping in a mosque, some armed men coming, their noise macle us get up, and we slyly left it, and went away to another mosque.

"The next day, being sickly and my feet sore, I was not able to keep up with the other two with the culleeaun in my hand. The lame Fakeer got vexed, and taking the culleeaun from my hands, they went off quickly; 1 went on a little, and beholding a small round room, I went in and lay dow'n, being affected with an attack of the fever; about dark, a Dooraunee on horseback, with a footman, came up, and 
seeing me, made inquiries, and wished to carry me on his horse, if I could not walk. I told them I was not able to go any how; they told me there was a fountain on the top of the mountain there, and gave me half a piece of very thick bread, which I could not then eat. In the morning I went up to the fountain, and eat and drank: another Afghaun coming, I gave him part of the bread, and went to the Rouza; thence to Gluuznee to the Fakeer's. Takeea, which was without the wall, and below, and had a pretty wide stream flowing across. I went into the town to the bazar, the roads being quite narrow and close; got some money, bought bread and soup and tobacco, and returned to the Takeea. The lame Falkeer and the young man thought proper to return, and I got acquainted with a Hindoostaunee Fakeer going on a pilgrimage, who said he was robbed of some money and a blanket: he behaved very kindly to me, and two days after he left the town, and went off with a caravan; but I could not, my feet being quite cut and bruised. The Fakeer of the Takeea was a tall old man of Hindoostaun, who had visited many parts of Tartary or Turkistaun, and had been near China, and had lived very long at Ghuznee; he was a kind and civil man; many came to his Takeea to smoke churse or tobacco. The Hindoos have very high houses of wood-work, several of them were kind to me, giving me three or four pice each ; one of them, a pair of shoes and a jacket of coloured cotton. It is a small walled town, about the midst of which is a covered bazar. I staid upwards of seven days, and proceeding, went to Nanee in the evening. They talked of a feast, and I went to it at dark. It was given in the open air : there were upwards of thirty people: the master sent round when dinner was ready, and all assembled: they had a large fre where they warmed themselves, and danced the attun: afterwards they sat down to dinner. When I came, they said a few worcls, and spoke jovially to me to sit down and eat; a man went round first with a bason and ewer to wash their hands; they then said bismillah and began.

"The dinner began with soup in wooden bowls; they broke their bread into it, and when it was soaked, eat it with 
their hands. There were also wooden spoons, but not one to each man. The soup was very good; there were spices in it. There was a bowl for every two or three : meat was given out into the hands of the guests, who put it on their bread. They eat heartily; every man had as much as he could eat. After eating, they all blessed the master, and wished him success. I did the same. This was all the dinner: after dinner they smoked: after this, some went away, and some stayed. I went away: the party began at nine at night, and broke up about eleven: the light was given by the fire. The women dined in the tents." Mr. Durie was at other feasts, which were much the same, except that in some places they had wooden platters for their meat; some went away, and others sat late talking; some sung.

"The next clay (says Mr. Durie) I went: to Carrabaug, thence to Oba; but arriving at night, the Killas I got to were broken and fallen down. I suffered much, owing to the sharp cold winds, throughout the night. In the morning went on, and arrived at a Killa which was inlabited, and got brearl and smoke. Proceeding towards Mooklor, a big strong young man attacked me with a thick club, and inquired and searched me, not forgetting to see closely my shoes: not finding ought, he on his knees begged pardon with folded hands. I muttered a blessing, went to Mookhor, and beheld a caravan of camels, \&c.; alighted, smoked, and went to the Killas, which, not being well inlabited, I did not get enough of bread: lowever, returning to the caravan, one of the women observing, gave me plenty. The next afternoon they set out; I followed: not being able to lieep up, went up to a set of Killas upwards of a mile distant from the road : arrived at dark, saw some of them seated by a stream, and told them I was not able, through sickness and fatigue, to go to the Killas : one of them pointed out the mosque, telling me he would fetch me bread. I went to it. At past eleven, a sick man came to pray : observing me, he went and brought me some bread. At past twelve, the first man recollected, and brought me half a piece of very thick bread, begging many pardons, and requesting I should pray that his faith might 
not fail again. The next day staged there, and was invited to a feast of meat, soup, and bread. The next day proceeded: not finding any Killas, was at a loss; saw a man going, asked, and he said he was going to a camp; he went off quick; I went the same track, and arrived there in the dark, and obtained bread, smoke, and nummud (felt) to sleep in. The woman who gave me the nummud, observing my feet sore, gave me some ghee (clarified butter) to anoint them, and advised me to wait. I did. A quarrel happened : one of the Afghauns, a young man, drew his sword; but he was checked, and the quarrel soon ended. A dance took place, the Afghauns in a circle holding each other, singing loudly, and huzzaing, bending their bodies, and clapping their hands. A great fire was made up; I was of course called jovially. Meat, bread, and soup, were served in bowls. The next morning proceeded, lodging in camps, and two days after met with an old Belooch Fakeer: we went to a camp, where they, having searched us, made us sing, and gave us bread and butter-milk."

Once some Afghauns enticed the Beloche and Mr. Durie out of their road, on pretence of showing them"a village: when they got them behind the hills, they searched them carefully, and did not let them go till they found they had nothing of value. The Beloche had some papers, which they returned. "Another time," says Mr. Durie, "having breakfasted at a khail, we happened to be benighted, and lay down not far from a camp : being wearied and dark, we could not go to it. Some of the $\Lambda$ fghauns hearing our voices, came to us, two of them supporting me there, and gave us fire, bread, and quilts to sleep on. The Fakeer wanting milk, they milked a goat and gave him. The next day, arriving at a water-mill, we got some flour, and went and were closely searched by some: I happened to fall back, owing to the soreness of my feet, and got to another watermill, where I stayed the night. The next day crossed the river, went to another mill, where an Afghaun, who had been at Lahore and Dillie, and talked a little Hindoostaunee, behaved kindly to me, carried me to his klkil, and got 
my flour baked, and gave me a pair of trowsers. The next morning set out; two or three days after, lodging at khails, arrived at Kelaut, on the top of a high mountain, but ruined and depopulated. As I had several pieces of my old trowsers packed up round my waist, I was often searched: lodging at the khails, arrived at Shalıur Suffa, which was destroyed and depopulated. A day or two after, happened to be benighted, walked all night, owing to the sharp cold winds, not being able to sleep : arrived at Gomana, a ruined town, in the morning; thence got to a stream and lay down; seeing an Afghaun, went along with him to a set of Killas, met with good treatment there, and got water-melons and khatucks; thence to Candahar in the dusk of the evening; went to the Chaur'soo (or narliet-place), and afterwards seeing Afzul Mahommed, a baker, an Akhoond Zada, and two or three Fakeers, sitting near a shop on the road over a fire and smoking, I sullamed : they asked who I was, I said I was from Hindoostaun, proceeding on pilgrimage: the Alkhoond Zada desired me to sit, giving me a culleeaun, saying Fakeers of Hindoostaun are generally respectable. They pointed out a small broken mosque to me; and $I$, after having sat by the fire and smoked, went there and slept with two or three Fakeers. The next morning called on them; they had their fire in the hall, which had a room on the side. Islam Khaun and another Khaun, with some others, were present; we smoked. I went to the Chaursoo and got some bread. 'Thence I went to a Falseer's Takeea, where I saw many Dooraunees, and other Moguls and Afghauns, sitting here and there in the spacious garden, talking and smoking. I smoked, got some copper money, eat some soup and bread at the Chaursoo, and returned to the baker's with tobacco. Sat by the fire with the rest, smoked, talked, and went to rest in the broken mosque. Some days after, the nephew of the baker, a lad, by the baker's desire, lent me an ink-stand and writing things, with which I went to an Alshoond, who had his little school in the Shecarpooree street, and was a man of Belochistaun. He beliaved kindly to me, and let me sit in his place and write odes, \&c.: happening to lay down one 
day on a raised spot, the ink-stand was stolen, for which I had to pay the lad eighteen pice (about nine pence). I suffered near two montls in the cold; however, owing to my passing a great part of the night by the fire at the baker's, I got on cumfortably: happening one day to go to a saddler, and talking of my journey, he afterwards spoke to a respectable Khaun who was humane; he gave me a poosteen, under which I slept and kept myself warm. One night, coming home too late, some Hindoo dogs fell on me, and tore it into several pieces; it cost me several pice to get it mended. I passed the time among many of the people here and there, they often making me sing English, with which they seemed well pleased.

"The shops of the different Hindoos, Mahommedan merchants, artificers, \&c. are always attended by Afghauns, Dooraunees, or Moguls, frequent and full. I happened one night to be at a Hindoo's shop when it began to snow. The Hindoos told me to stay, and brought me fire and bread in the night. For three nights snow fell heavily. Three or four days after, the weather began clearing up, and the sun to shine. I then found myself much better. When the sun was clouded and sharp cold winds blowing, I found myself unwell and uneasy, unless cheered and warmed by a fire. As soon as the sun began to shine, the people, Hindoos and Mahommedans, every Friday went out to pleasant places of devotion and entertainment; also on other days to excellent gardens, cooks, bakers, pasters, (qu. pastry cooks i) fruit and sweet-meat sellers, musicians, \&c. \&c. attending, more or less, according to circumstances. I went several times to Kliaujeh Khezur, Abasabad, and Baba Wullee, all these being very delightful places and prospects, with trees, waters, hills, and mountains. I seldom went about in the houses; but six or seven times I saw some of the apartments of some of them, which were curiously and commodiously made. The people passed their time happily and cheerfully, seldom saw them quarrel with any degree of animosity, though they are quarrelsome enough; several times saw Hindoos and Mussulmauns quarrel, also Mussulmauns with Mussulmauns; those happened 
to be only with words, some blows or wrestling, and terminated without bloodshed, or loss of any member. 'Three or four times Afghaun robbers had their bellies ripped open, and were carried about the streets, hung on the necks of camels, and a man with a drum telling the cause of their punishment: they were afterwards hung for one day in the Chaursoo.

"One night, long before the snow had fallen, observing the houses and shops were somewhat illuminated, I inquired of the cause, and was told Mahmood Shah hacl taken Peshour, and Shujaool Mulk fled. On the day of the Ead, after the Ramzaun, Camran Shahzaada, who generally sequestered limself in his walled Killa, went through the gate to the right of that called Cabulee, to a spacious plain, hard by the mountains, with a retinue of horsemen, who tralloped about firing their muskets, great numbers of men and veiled women having gone to view the show; and at a place not far from his Killa, he ordered two or three feasts of pillaw to be given to the people, to which $I$ went, but seeing several beaten, went off. Another day saw his sawaree (procession); he was at the head of them, and appeared to be a man of good size and make. They had long ensigns and long spears, and passed throngh the Chaursoo, having come from an airing and visit to some places sacred or recreating. I three or four times beheld a marriage procession of men, boys, women, and girls, on hor'ses and camels, passing about the streets; the horsemen accompanying, galloped about, backwards and forwards, firing their guns. While I passed the night at the baker's, or the broken house, I heard now and then one of the two Khauns, who daily and nightly came, play on the Rubaub melodiously, and in company with the baker, sing with great glee; also some Fakeers and others came and sang or chanted day or night, but not always. I also heard Hindoo men or women who lived thereabouts very frequently sing, with a variety of music at nights, and now and then Mahommedan women or men who resided hard by. When the Hincloos went to places of entertainment, they sang with music, or had enough of both, 
with dancing. They have several Dlarum Seroys in the towns, to which they often resorted for purposes of acloration, business, or entertainment.

"When the weather became warm, told Teerut Doss, and the other Hindoos, of my intention of returning. They wanted me to stay, alleging they would contribute their assistance to enable ne to do something for myself, but as I was determined to get away, they gave me some pice, also some Mahommedans upwards of a rupee, and I bought some pepper, brown sugar, and dried fruit, and set out from the Caubulee gate; I saw the baker sitting as I passed, and he desired me to stop, and not go away, lest I sliould get killed or hurt. He had been for some time out of employ, but had something in store, and had some relations also doing business. He was a clever man and of a good disposition, but seldom performed his Namauz; the Akhoond Zadah and the other Fakeers never did; and during the fast of the Ramznun, in their closets they smoked."

After Mr. Durie left Candahar he went on for six marches, sometimes searched and sometimes feasted, generally by the common people, but sometimes by the sons and laclies of Khauns. He says but little of the country; except generally, that both in going and returning he kept off the main road for the sake of camps, which were pitched nbout the skirts of the northern hills, where there was, he says, "a charming road, and a glorious country." One day he came to a mill, and was advised to go on a little way to a place where there were some petty Khauns. "They pointed out to a place where were trees, streanss, and melon-beds, and I there found two young Khauns, tall, stout, and well made men, and two Moollahs (one of them an old man with a long white beard), with servants and horses. They talked civilly, and gave me tobacco to smoke. Soup being ready, the old Moollah gave me some meat and soup, the Khaun a large piece of meat, and a few minutes after, a large clean loaf baked on purpose. They themselves eat no bread with their soup and meat. Having eat, drank, and smoked, they sullamed, and went off. I also, proceeding in the dark, arrived 
at a water-mill; the owner shut the door and refused me entrance, desiring me to go to another place not far off; but I would not mind, speaking politely and persuasively, and saying I must have a lodging; at last I offered a leather bag I had, which he took and suffered me to tarry, but gave me plenty of fire. The next morning he pointed out to a Khail ; I went about three coss within the hills, a lad carried me to a large one, where $I$ tarried the next day, also very good treatment of bread and butter-milk, and tobacco: several saying they would entertain me some days, but the times were hard. Thence in the dusk arrived at another Khail, a good way off. Met with good treatment. A few days after, from Khail to Khail, arrived in the evening at Nanee." From this Mr. Durie went on to Ghuznee; on his road he. met lis old fellow traveller, the lame Fakeer, who told him he had been near Bagdad, and had returned.

At Ghuznee Mr. Durie remained eight days at a Fakeer's Takeea, where he met "a Tartar Fakeer, who said he had travelled to many places of Persia, Syria, Constantinople, Arabia, and Malta, of which, by his conversation, he gave many proofs. He secmed to be a very good, civil man." While at Ghuznee lie saw an Afghaun, who had robbed some travellers of a mule, brought in by some Dooraunees, with his hands tied behind him. "I went one evening," says Mr. Durie, "to the governor, who resided in the citadel; when he came out on horseback, with some horse and foot attending; I asked him for some assistance. He asked from whence I had come; I said from India: then says he, joking, you ought to give me something; however, he desired me to wait, and when he returned, an attendant on horseback gave me some copper money. I went to visit the tomb of Sooltaun Mahmood, which is a dome-like edifice, with a large door; the grave of white marble, with Arabic inscriptions. Some Korauns are lodged upon it, and many continually come to worship. There are many fine apartments, well and curiously fashioned, connected with the court-yard of it, where there are several stone images of tigers, \&c."

Leaving Gluznee, he at last reached Killai Shaboodeen, 
" where were very fine castles, fine streams of water, and excellent fields of green in the vales beneath the mountains. Met with a Khaun having a musket in his hand; he spoke civilly with me to go to Caubul through Tymoor and Lelunder; went to Tymoor in the evening; met with good treatment; proceeded along the narrow river, flowing with rapidity between the closing mountaius on both sides; below abundance of fruit trees and fields of green; in the dark arrived to a Killa belonging to an Akhoond (teacher or Moollah), who was kind."

The following adventure liappened on his way to Caubul: "One evening arrived at a khail, or camp, observed some praying at a place surrounded with stones (which they in the khails hold as a mosque); I went up and began as they. They took mucl notice, and when done, they laughed, as I performed it incorrectly. I macle excuses to the Moollah, who, being good-natured, behaved kind, and asked about medicines. Two or three other times I performed Namauz, and the people coming round, laughed; I told them I clid well enough, as I could."

At a place called Lullunder he was struck with the beauty and magnificence of some castles, which he never saw equalled; but he says, "They were of a singular kind, and very hard to describe, unless I could paint them. Slept at a large mosque; went to other castles, breakfasted, saw on a very high mountain a small house, which they termed Poytukt Zemaun Shauh (or the throne of Shauh Zemaun); not far from it is Sultan Bauber's small white stone mosque; (one day I went there; there having come many veiled ladies, I was not allowed entrance; one of them returning on horseback, her horse happening to run swift, she tumbled down, and others went up to her assistance). On my arrival at Caubul, a respectable man invited me, giving me bread and pillaw. I slept at a mosque in the town: in the morning went to the Takeea at the Lahora gate. They received me kindly. Stayed there upwards of twenty days, sleeping at a mosque, though the head Fakeer often desired me to rest at the Takeea; went about the bazars daily; at times saw 
several chiefs on excellent horses, having fine coloured garments and turbans, pass by, with many footmen going before. Discoursing at the Takeea or elsewhere, they frequently asked if I was a spy: one at the Takeea, a sharp cunning man, discerned that $I$ was not circumcised, but he and some others held their tongues. In discourse with some of them there, and at the mosque, concerning Ferungees (Europeans), it was remarked that many customs accorded in the Alcoran and Scriptures, but that, owing to reasonable circumstances, reasonable innovations had taken place, to which they agreed and gave consent. The head Fakeer one evening, not being in the way, I sullamed to the others, and was going off, when he happened to come and called out. I returned, and telling him I was going, he gave me his blessing. At dark arrived at, Bootkhak."

Mr. Durie went on towards Peshawer with some little caravans: once being behind the rest, he met with the following adventure: "When going alone, I met a young Afghaun having a matchlock and a large knife; asked of him how far Gundamuck was; he said one royal munzil, and went off; but he afterwards holloed after me to stand; I obeyed; he wanted me to go among the mountains, saying I was a spy, a magician, an alchymist, or a Persian. I said I was an Hindoostaunee: he struck me hard on the thigh with the back of the knife, and made many thrusts, till he drew some blood, when he begged pardon, and sheathed his linife." "Another day getting astray from the main road, I proceeded through the mountains, and became several times blocked up so, that to extricate myself, I was often obliged to climb up and get down from high rocks. Slept there in the night, about ten in the morning arrived under the shade of a mountain, where several Afghauns were. They gave me bread, water, and smoke, and pointed out Lundee Khann, situate aloft." From this he got to Peshawer, and crossed the Indus without any further adventures.

The following is one of three sheets which were written by Mr. Durie before I conversed with him. They contain 
his general opinions, which seem to me often correct, and sometimes very sagacious for a man in his sphere of life.

"The mountainous districts about Atuk, Peshour, Caubul, and Candahar, and beyond Caubul towards Bulkh, and beyond Candahar, towards Heraut, comprehend the Afghaun realm, called Khorassaun. The Afghauns being different tribes, have different denominations; and unless brought under proper subjection, by force or fortune, they are at continual variance with one another. Ahmed Shah and Timoor Shah being fortunate enough to keep up a great army, which enabled them to subjugate foreign territories, they all voluntarily submitted to them, (though these chiefs had gained power enough to humble them in no littie degree, ) as thereby they acquired advantageous employment. However, it is evident that a regular courageous army, having provisions, can make them all subnait completely. 'The Mogul Kings of 'Tamerlane's race having had them in undoubted subjection, the surrounding mountains being more favourable than deterring or inimical. The Dooraunees reside about Candahar, though there be not many of them there now ; in the present times, their Shahs not being able to make foreign conquests, the name of Dooraunee prevails not, many tribes not sending any tribute or contribution. The followers of the Shahs and Sirdars are by no means all Doornunees, though they may be so denominated; they are fond of committing depredations in their own territories, as they have not good luck enough in these limes to carry the terror of their sword to foreign domains. The dominion of Alumed Shah and Timoor Shah had been extensixe, in which they had prospered well; but they think of nought but conquering, they look not for the acquisition of riches, of which they are infinitely desirous, by the gloriously useful arts of industry, they want it by the snite of the sabre; but, however, there are allowances to be made for the sarne, they being pent up and enclosed in the midst of surrounding hills and mountains, having all around many and inveterate powerful antagonists who have often subdued them; their territory vOL. II. 
having been held as a province: they also have extended their arms to distant countries. They imagine their religion to be the best and most true, consequently they consider all others as misled or erroneous, hoping, on account of the superior truth thereof, to vanquish all in the end. Though they fight one another, being Soonnee Mahommedans, (in conformity with the Turks, and Tartars, and Arabs, holding. the Persians as misled,) they refiain from such degrees of animosity as might urge them to their own destruetion or extirpation. That they hold their religion to be the best is undoubtedly not their fault, they being strictly initiated to imagine so: however, the spirit of toleration, owing to philanthropy, does not a little nctuate them, though at first they might wish to Mahommedanize all men, for many of them are certainly free, liberal, and tolerating. The Fakeers, \&c. of Hindoostaun, who go to their countries, do not fail in their envours to make them believe false and incredible representations, and they are weals enough to give a good deal of credit to them. They hold the people of Bengal as perfect magicians, and the Europeans (whom they reckon as wise, intelligent, and equitable) as perfect chemists, well versed in the art of malking gold. As I told them often $I$ came from Bengal, they troubled and questioned me much, imagining that I must necessarily be acquainted with many such arts; however, repeating the Mahommedan creed, or culma, though my clothes were torn, and they often took me to be something of the misled, as I performed not Namauz, \&cc. yet they were satisfied with respect to my being a Mahommedan, not presuming to trouble or interrogate beyond moderation. Hindoo or Mahommedan travellers pass safely through their countries, receiving victuals from them; but they cannot pass at all with any thing valualle, as there exists no discipline or regularity of government among them. They often declared that when the Mogul government had existed there, people might have carried gold openly, without apprehension or danger, through the routes of the cities. The government now is in the Afghaunee hands, they being all Afghauns of different tribes, the Dooraunees being the 
most powerful; upon emergencies of good luck, the others willingly attend, being so denominated, for men of the different tribes attending the victorious Shahs or Sirdars, are so called, they being all Soonnee Afghauns of Khorassaun. A very great part of the people of the cities, being shopkeepers, artificers, and such like, are not Afghauns, but spring from other originals. At Peshour a vast number of Mahommedans talk a kind of Hindostaunee language, and dress, \&c. differently from the Afghauns, though they generally understand more or less of Pushtoo. The greatest part of the shops are held by Hindoos, also there are many Sheeah or Persevaun cloth merchants, \&c.; and many of them, called IKuzzilbaush, attending on the Shalls and chief Sirdars.

"These countries are held now by different Afghaun Sirdars, at variance with cach otleer, as they are not at first favoured by fortune to invade or conquer; if they were, they would voluntarily and joyfully attend on the fortunate leader: They often talk of the English conquering them, and many of them declare they will; many snying that they would rather have the Seeks or Mahrattas invade them with half a dozen lacs than the English with three or four thousand. The dominion of Khorassaun, which is inhabited by different tribes of Afghauns, more or less strong, all of them being Soonnees, talking Pushtoo, and in their various manners agreeing, has been often held by other more powerful empires as a province; but of their tribes none appear to be manifestly so powerful as independently to hold the rest in complete subjection. And when fortune favours, they unanimously; without being compulsively called forth, yield their respective assistances in co-operation with the fortunate tribe. But in these days they have not any unanimity, nor any lind of regular army, nor aught of governmental regularity, nor of national industry or exertion, so as to be accounted a respectable nation; in their own dominion, nevertheless, in their respective clans, they are very well, happy, and regular.

"They have no regular armies whatever, being all in no good order, and they are not able to make use of the gun. The routes to Caubul and Candahar being without defence, 
robberies and oppressions are committed by all sorts and ranks, though the mountains about the road may be rendered inaccessible. The black tents are set in order this way or that, but near one another, in general conformably to the ground.

"Their flour or grain, \&c. is kept in bags or packs. They have some articles and conveniences. 'They all have iron and stone plates to place their bread on for baking, and ovens also. They generally eat bread and rice with butter-milk, milk, and meat-soup at times, having many dumbas and goats. Their women cook, balke, bring water, \&c. They keep and bring their water in leathern bags. They appeared well clothed and happy. 'l'hey are hospitable to strangers. They like tobacco, but they had very little of it when I went; they only take one strong whiff each, sitting around. If the time and seasons be good, having plenty, they delight in manifesting their hospitality. There being no regularity, of course no one can pass safely with any thing valuable without being guarded. They are regular in their Namauz. In the cities one might pass along without Namauz; but in their khails, or seah khanas, or black tents or killas, one cannot abide any time without being questioned."

Of the remaining two sheets, one contains Mr. Durie's travels through the Punjaub, and the other an account of his journey to Candahar in less detail than what has been given : one or two observations from this sheet, have, however, been quoted in my text. 


\section{APPENDIX C.}

ACCOUNT OF SOME NEIGHBOURING COUNTRIES.

Thougr they are not included in the King of Caubul's dominions, I make no apology for giving an account of the Caufirs, or for stating the few facts I know about Budukhshaun and Kaushkaur, countries of which the names alone are known in Europe.

The following passage is quoted in Rennel's Memoir of a Map of Hindoostaun.

"There is a certain tribe at this day inhabiting modern Bijore (Bajour), or at least there was not long ago, who pretend to be the descendants of certain persons belonging to that conqueror's (Alexander's) army, who, they say, were left there as he passed through the country. Both Abool Fuzl and Soojun Rae report this tradition without material variation. The latter, indeed, adds that these Europeans (if we may call them so) continued to preserve that ascendancy over their neighbours which their ancestors may be supposed to have possessed when they first settled here." (Kirkpatrick's MSS. quoted in Rennell's Memoir, page 162, ed. 1794.)

It may easily be supposed that this account excited great attention during the journey of the mission to Caubul, and that we were not long at Peshawer before we began to inquire after our Macedonian neighbours. We were soon obliged to give up an opinion, derived from Abool Fuzl, that these colonists were a branch of the Eusofzyes ; but we learned that the Caufirs, a people in the mountains north of Bajour, had many points of character in common witli the Greeks. They were celebrated for their beauty and their European complexion, worshipped idols, drank wine in silver 
cups or vases, used chairs and tables, and spoke a languagc unknown to their neighbours.

It was not easy to gratify the curiosity these descriptions excited, for although I early determined to send a person to make inquiries on the spot, it seemed impossib]e to prevail on any one properly qualified to engage in a journey into the country of a people among whom there was no action so honourable as the murdur of a Mussulmaun. At length the adventure was undertaken by Moollah Nujeeb (a brother of Moollah Behramund already mentioned), a person admirably fitted for the task by his talents and curiosity. He left Peshawer in the middle of May, and penetrated into the comntry of the Caufirs by the way of Punjcora. The mission set out for India about a month afterwards, at which time no news had been received of him: as long as we continued in the Afghaun dominions, we entertained strong hopes of his return; but when the second month had elapsed, and we had half crossed the Punjaub, we began to be uneasy about him, and his brother who had accompanied me so far, returned to make inquiries concerning him, under a persuasion that he had been murdered by the Caufirs. I had no tidings of him from this time till I had been for some months at Dehli, and I had given up all hopes of ever seeing him, when he unexpectedly arrived in Camp, having undertaken this long journey from his own country rather than disappoint our expectations. He had been as far as Caumclaish, a village within three stages of Budukhshaun, had made himself master of every thing relating to the Caufrs, had completed a vocabulary of their language, and brought full answer's to a long hist of queries with which he had been furnished at his departure. The following account is chiefly $\overline{\mathrm{ab}}$ stracted from his report, which was translated by Mr. Irvine; but as $I$ had opportunities of obtaining further information during the Moollah's absence, I have made use of it to check and to illustrate his account.

I'he principal sources from which this additional information was clerived, were, a young Caufir whom I had opportunities of interrogating; a Hindoo clerk of Mr. Irvine, who 
had visited the country of the Caufirs; the Syud of Coonner's agent, who lived on their border: and an Eusofzye, who had been engaged in a military expedition into their country. The geography is taken, as usual, from Lieutenant Macartney.

The country of the Caufirs occupies a great part of the range of Hindoo Coosh, and a portion of Beloot Taugh. It is bounded on the nortli-east by Kaushkaur, on the north by Budukhshaun, and on the north-west by Koondooz in Bulkh. On the west it has Inderaub and Khost, also in Bulkh, and the Cohistaun of Caubul ; and on the east it extends for a great clistance towards the north of Cashmecr, where its boundary is not distinctly known.

The whole of this Alpine country is composed of snowy mountains, deep pine forests, and small but fertile valleys, which produce large quantities of grapes, wild and cultivated, and feed flocks of sheep and herds of cattle, while the hills are covered with goats. Grain is inferior, both in importance and abundance. The common kinds are wheat and millet. The roads are only fit for men on foot, and are often crossed by rivers and torrents, which are passed by means of wooden bridges, or of swinging bridges made on ropes of withy, or some other pliant tree. All the villages that I have heard described are built on the slopes of hills, so that the roof of one house forms the street leading to the one above it; and this is said to be the constant practice of the country. The valleys must be well peopled; that of the Caumojee tribe, at least, contained ten villages, and the chief place, Caumdaish, consisted of five hundred houses.

The people have no general name for their nation. Each tribe has its peculiar name, for they are all clivided into tribes, though not according to genealogy, but to geographical position; each valley being held by a separate tribe. The Mussulmauns confound them all under the name of Caufir or infidel, and call their country Caufiristaun. They also call one division of them Seeaposh (black vested), or Tor Caufirs (black infidels), and another Speen Caufirs (white infidels). Both epithets are taken from their dress, for the whole of the 
Caufirs are remarkable for tho fairness and beauty of their complexion, but those of the largest division wear a sort of vest of black goat-skins, while the other dresses in white cotton."*

There are several languages among the Caufirs, but they have all many words in common, and all have a near connection with the Shanscrit. They have all one peculiarity, which is, that they count by scores instead of hundreds, and that their thousand (which they call by the Persian and Pushtoo name) consists of four hundred, or twenty score. All these observations apply also to the Lughmaumee or Deggaunee language, which seems to be a Caufr dialect, and gives reason to suppose the Lugmaunees and Deggauns to be Caufirs, converted to the Mahommedan religion. I imagine the inhabitants of the Cohistaun of Caubul to have the same origin, particularly as the name of Cohistaunee is that applied to all the lately converted Caufirs.

This derivation of their language seems fatal to the descent of the Cenufirs from the Greeks, and their traditions do not furnish us with any distinct account of their origin. The most general, and the only credible story is, that they were

* The following are the uames of some of their tribes. The first set were given by the young Canfir of T'sokooee, the second got by Moollah Nujeeb at Caumdaish, and the third by Dhunput Roy at Kuttuun, and on the borders of Bajour.

1. Traiguma, Gimeer, Kuttaur, Bairagullee, Chninaish, Dimdeau, Waillee Wruce, Cuuna, Cooshteen, Dhaing, and Wauee, called Puneeta by the Mussulmauns.

2. Caumojee, Kistojee, (whose chief lown is Muncheeashee), Moondeegul, Camtoze (half of whom are torvards Budukhshaun, and half towards Lughmaun,) Puroonee, whose capital is Kishtolsee), Ternee, Poonooz, Ushliong, Umshee, Sunnoo, Koolumee Roose Turkuma (to whom belong Kataur and Guinbeer), Nisha, Clumga, Wauee, Kloollum, Deenish, Eerait, \&c. \&c.

I must observe that one of Moollah Nujeeb's list is Pusha, which is stated to live towards Caubul, and wlsich I doubt not is the origin of tile Pushawees mentioned by Bauber, and still found in the Cohistaun of Caubul.

3. Wauee Daiwuzee, Gumbeer, Kuttaur, Pundect, Khoostoze, Cnumozee Dirine, Tsokooee, Hurunseen, and Chooneea. 
expelled by the Mussulmauns from the neighbourhood of Candahar, and made several migrations from place to place, before they reached their present abode. They allege that they consisted of four tribes called Camoze, Hilar, Silar, and Camoje, of which the three former embraced the Mahommedan religion, but the fourth retained its ancient faitl, and quitted its native country.

Their religion does not resemble any other with which I am acquainted. They believe in one God, whom the Caufirs of Caumdaish call Imra, and those of Tsokooee Dagun; but they also worship numerous idols, which they say represent great men of former days, who intercede with God in favour of their worshippers,

These idols are of stone or wood, and always represent men or women, sometimes mounted, and sometimes on foot. Moollah Nujeeb had an opportunity of learning the arts which obtain an entrance to the Caufir Pantheon. In the public apartment of the village of Caumdaish was a high wooden pillow, on which sat a figure with a spear in one hand, and a staff in the other. This idol represented the father of one of the great men of the village, who had erected it himself in his life-time, having purchased the privilege by giving several feasts to the whole village; nor was this the only instance of men deified for such reasons, and worshipped as much as any other of the gods. The Caufirs appear incleed to attach the utmost importance to the virtues of liberality and hospitality. It is they which procure the easiest admission to their paradise, which they call Burry Le Boola, and the opposite vices are the most certain guides to Burry Duggur Boola, or hell.

This facility of deification must render the number of the gods very great, but many must be confined to their own tribe, since it cannot be expected that those will worship them who have never partaken of their entertainments. Accordingly, the gods of Caumdaish scen to be quite different from those of 'T'solkooe, though there is one common to both, and there may probably be more who may have been deified before the 
separation of the Caufir tribes. The chief gods, or heroes, of Caumdaish are, 1st, Bugeesh, who is god of the waters; 2nd, Maunee, who expelled Yoosh, or the evil principle, from the world; 3rd, Murrur; 4th, Urrum; 5th, Pursoo; 6th, Geesh, $7 \mathrm{th}$, Seven brothers of the name of Paradik, who had golden bodies, and were created from a golden tree; 8th, Purron, seven golden brothers of the same kind; 9th. Koomye, whom Moullah Nujeels calls the wife of Adam; 10 th, Dissaunee, wife of Geesh; 11th, Doohee; 12 th, Surijoo; and 13th, Nishtee.

Those of the Tsokooee are Maunde, perhaps Maune, before mentioned. Maraist, Murrasooree, and Inderjee, who may perhaps be the Hindoo god Inder, or Indra, with the Indian title of Jee annexed to his name. Dhunput Roy (Mr. Irvine's Hindoo) was indeed positive in stating that the Caufir idols represented the Hindoo god Seddasheo, and always bore a trident, which is the symbol of that god. He also said that they called some of their gods Shee Mahadeo, and that they used the same words as a salutation to each other; but these circumstances are inconsistent with other accounts, and as Dhunput Roy himself admitted, that the Caufirs ate beef, it seems improbable that they bear so close a resemblance to the Hindoos. All accounts also represent thern as sprinkling their idols with blood, and even witll the blood of cows, which cannot be reconciled to the Hindoo religion; and all represent fire as requisite at every religious ceremony.

Moollah Nujeeb was present on an occasion of this kind at Caumdaish; it was a sacrifice to Imra, and was celebrated at a particular place near the village where there was a stone post, which appears, by the Moollah's description, to have borne some resemblance to the Hindoo emblem of Mahadeo : a fire was lindled before it, through which flour, butter, and water were thrown on the stone; at length an animal was sacrificed, and the blood thrown through the fire on the stone; part of the flesh was burned, and part eaten by the assistants, who were numerous, and who accompanied the priest in various prayers and devout gesticulations. One of the prayers was 
for the extirpation of the Mussulmauns.* 't'he worship of idols is perfumed nearly in the same way. These are sometimes in the open air, and sometimes in houses called $\mathrm{Imr}$ Unma. 'Though fire (made of branches of a particular tree) be necessary for all religious ceremonies, yet they seem to have no particular veneration for that element, and keep up no eternal fire.

They have lereditary priests, but they have no great influence. They have also persons who can procure an inspiration of some superior being, by lodeling their heads over the smolie of a sacrifice, but these are held in no particulitr reverence. They detest fish, but hold no other animal impure, cating alike beef, mutton, bear's flesh, and any thing else they can get.

Though they have sacrifices on all days when they please,

- Some may be interested by the following tetails of the ceremony. 'Tlue wook used in the sacrifiee, whizch Moollnh Nujeeb calls Kauchur, is named Kesopoote Thoop by the Canfirs, necording to Dhunpore Roy,

"There is a stone set upright about four feet high, and in brealet about that of n stout man. This is the Inrtan, or loly stons, an! behind it to the north is a wall." This is all the temple. The stone represents God. They say, "This stands for him, but we know not his stape." To the south of the Imrtin burns a fire of Knuchur, a species of pine which is thrown on green, purposely to give a $\mathrm{grent}$ deal of sunoke. $\Lambda$ person whose proper nume is Mulcel, and his title Ota, stands before the fire, and behind him the worshippers in a row. First, water is brought him, with which he washes lias hands, and taking some in his right hand, throws it three times through the suoke or fane on the Imrtan, saying every time Spoch, that is, pure; then lie throws a handful of water on the sacrifice, usually a goat or cow, and says Sooclk. 'Then taking some water, and repenting some words (meaniug, "do you accept the sacrifice?" \&ce), he pours it into the left enr of the secrifice, which stinds on his right. (Moollah Nujeeb saw two sacritices, one to God, and one to an idol.) If the animal norr turn up its heal to hearen, it is recknned a sign of ncceptunce, and gives great satisfuction; afterwards in the right ear, and a thirl time on the forehear, and a fourth on its back. Each time Sooch is once said. Next throwing in some fuel, he takes a handful of iry wheat flour, and throws it through the fire on the stone; and this flour they reckon a part of God; and ngain he throws both hands full of Gliee ineo the fire; this also is a portion of God. They do not in either of these ceremonies sny Sooch, but now the priest says with a loud voice, He! and after him three times the worshippers and he say He Unnch! that is, accept! This they accompany each time with a geslure. They put their palns 
yet there are certain fixed festivals, which prevail among the Caumojes of Caumdaish, and which Moollah Nujeeb thinks may be general. Some of these are remarkable, but none resembles any festival that I am acquainted with, except one; at which the Caufirs throw ashes at each other, as the Hindoos do a sort of powder during the Hooly.

The festivals are often accompanied with a sacrifice, and always with a feast; at one the boys light torches of a sort of pine, and carry them before one of the idols, where they throw them down and allow them to burn. At another the women hide themselves without the village, and the men search for them; when found, the women defend themselves

expanderl on the outside of their knees, and as they raise them in an extended position, sny He Umuch! The priest now kills the gont with a knife, and receiving in both hands the blood, allows a little to drop into the fire, and throws the remuinder through the fire on the Inurtan, (or idol, in case of an idol,) and again three "He Umuch!" The head is now twisted off (to the left), and thrown into the fire, but no "Hc Utnuch!" Wine is then lrought in a bowl, and the priest dropping a little into the fire, throws the rest througl it, (the ghee too was thrown ont of a bowl, and three He Umnch! The priest now prays God, "Ward off the fever from us! increase our stores! kill the Mussulmauns! after death adınit us to Burélebóoln, or paradise!" and three He Utuuch are said. The priest now brings forward and places before himself a Pusha, or person possessed by a spirit, who, after stretching forward his hend into the smoke, and shaking it in it, turns up his eyes to henven, and prays as before; the priest and worshippers three times say loully He Uinucla! Next each man puts the tingers of each liund together to his mouth and kisses them, next to his eyes, and lastly to his head: then all retire, and sit or lie down in one place. They now put the blood of the victim, with a little water, on tlue fire, nnd after it lins simmered $n$ little, put in the flcsh, which is soon taken out half raw and eaten. Bnt if the victim be a cow, it is divided, and each man carries his own home. The priest gets a double share in both cases. During the meal they sip some wine, mixed with a denl of water, and furnished by the person whogives the rictim. The bones are now burnt. The circumstances are the same when the sacrifice is before an idol, but the only one of this sort scen by Moollal Nujeeb, was to Koomy, an idol some distance to the south of the village, on a height of difficult access; they contented themselves with throwing those things towards it. They had no Kibla, and their idols face always indifferently; but Moollah Nujeeb cannot now tell whether in all the Uurtans and Umrunias the worshippers face to the north. A cow is struck one blow with an axe on the forehead, of which it dies. 
with switches, but are finally carried off by the men. Some said that any woman who came to hand was carried off by any man, but Moollah Nujeeb, from modesty, did not question them on the subject.

Their other ceremonies are less connected with religion. At the birth of a child, it is carried with its mother to a house built for the purpose without the village; they remain there for twenty-four days, during which time the mother is reckoned impure; and there is a similar house for other women to inhahit during certain periods, when the Caufirs reckon them impure. At the expiration of the twenty-four days, both mother and child are bathed, and carried back with dancing and music to the village. When the child is to be named, it is held at its mother's breast, while the names of its ancestors are repeated to it, and they give it the name, at which it begins to suck.**

The age of marriage is from twenty to thirty for the men, and fifteen or sixteen for the women. The ceremony begins by the intended bridegroom sending some fine clothes of cotton ornamented with worsted (the manufacture of the Afghaun country), with some ornaments to the proposed bride. He also sends the materials for a feast to the girl's father and her relations; that night is spent in feasting, and on the next the lover comes for his bride, who is dressed in the finery he has given to her. The father adds a silk handkerchief and some other ornaments and articles of dress for the bride, and gives a cow, and perhaps a slave to the bridegroom. The girl is then led out with a basket on her back containing fruits and walnuts prepared with honey, and (if the family can afford it) a silver cup. In this manner she proceeds to her husband's house, the whole village attending,

* The common names at Caumdaish were Chundloo, Deemoo, Hnzami Meeruk, Bustee, and Budecl. The names of certnin men at Tsokooce werc Gurumbaus, Azainr, Doorunaus Pranchoolla, Gerneeruk, Kootoke, Oodoor, Kummur, and Zore. Those of certain women were Meeankec, Junnilee, Maulec Daileree Jeenoke, Zoree Puckloke, Malkee, and Aznuree. The names of four men at Kuttaur were 'Toti, Hoth, Gospura, and Huzaur, and of ane woman Kurmee. 
dancing and singing. Some days afterwards the father receives the price of his daughter, which is said sometimes to amount to twenty cows. The priests have no share in the ceremony. The women do all the drudgery of the family. Dhunput Roy states that they even till the land. Polygarny is allowed. There is no concealment of women. Adultery is not thought much of, though there is a punishment for it.

Besides their wives, the rich Caufirs have male and female slaves. These are all Caufirs (for they take no prisoners in their wars with Mussulmauns). Some of them are taken in battle from tribes with which they are at war, and others stolen from those with whom they are at peace, but the greater part are people of their own tribe, it being quite common for powerful men to seize on the children of weak ones, and sell them to the Mussulmauns, or keep them for their own use: a person who loses his relations is soon made a slave. The slaves who are retained in the tribe, however, are notill used, though not exactly on a footing with the free people of the family they belong to.

The funerals of the Caufirs differ much from those of other nations. When a person dies, he is chessed in his best clothes and extended on a bed, on which his arms are laid by his side. This is carried about by some of his relations, while the rest sing and dance round it, the men performing a sham-fight, but the women lamenting: from time to time the body is set down, and the women weep over it. At length it is shut up in a coffin, and deposited in the open air under the shade of trees, or in some other suitable situation. Every funeral concludes with an entertainment, and once a year a feast is given in memory of the deceased, and some food is exposed for his manes, which are invoked to come and partake. It has been mentioned that some attain to the rank of gods after their. death; there is another way of securing posthumous reputation, by the erection of a gate near the way side. It is but a simple structure, consisting of four beams and a few yards of masonry, and is of no use ; but it is called after the naine of the founder, and the enjoyment of this honour must be purchased by many feasts to the village. A strange account 
is given by Dhunput Roy of their ceremonies of condolence : a person who visits another that has lost a relation throws his cap on the ground when he cnters the house, then draws his clagger, and, seizing the hand of the afflicterl porson, makes him rise, and join him in dancing for some time about the room.

I can give but little account of the government of the Caufirs. It is uncertain whether there are any acknowledged magistrates; if there are, they have very little power, every thing being done by consultations among the rich men. They seem to practise retaliation like the Afghauns, and I know of no other administration of justice. They bave no titles of their own, but they have borrowed that of Khaun from the Afghauns for their rich mell. Their property chiefly consists in cattle and slaves : a rich man at Caumdaish had about eiglt hundred goats, near three hundred oxen, and eight families of slaves.

The whole dress of the common people among the Seeaposh Caufirs is composed of four goat-skins, two of which form a vest, and two a kind of petticoat. The skins have long hair on the outside; the upper ones do not cover the arms; the whole is fastened on with a leathern belt. They go bareheaded, unless they have killed a Mussulmaun, and shave their heads, except for a long tuft on the crown, and perhaps, two curls over the ears. They also pluck out the hair from their upper lip, cheeks, and neck, but wear beards four or five inches long.

Those in good circumstances, and those near the Afghauns, wear a shirt beneath their vest, and in summer the shirt forms the whole of their clress, as it always does with the women. The great do not wear goat-skins, but cotton cloth or black hair cloth. Some also wear the sort of white blanket, woven in the neighbouring country of Kaushkaur. The blankets are put on like Highland plaids, come down to near the knee, and are fastened with a belt; they also wear cotton trowsers, which, as well as their shirts, are worked all over with flowers in red and black worsted. The trowsers are slit at the bottom, so as to make a sort of fringe. They 
also wear worsted stockings, or perhaps worsted fillets, rolled round their legs, and the warriors wear half-boots of white goat-skin.

The dress of the women differs little from that of the men, but they have their hair plaited and fastened on the top of their head, and axer it a small cap, round which is a little turban: they have also silver ornaments and many cowry shells. The virgins wear a red fillet round their heads.

Both sexes have ear-rings, rings round the neck, and bracelets, which are sometimes of silver, but oftener of pewter or brass. They are left off during mourning; and with the men they are assumed, with much ceremony, and expensive feasting, after the age of manhood. The honorary distinctions in the dress of the men will be mentioned hereafter.

The houses of the Caufirs are often of wood, and they have generally cellars where they keep their cheeses, clnified butter, wine, and vinegar. In every house there is a wooden bench fixed to the wall with a low back to it. There are also stools, shaped like drums, but smaller in the middle than at the ends, and tables of the same sort, but larger. The Caufirs, partly from their dress, and partly from habit, cannot sit like the other Asiatics; and if forced to sit down on the ground, stretch out their legs like Europeans. They have also beds made of wood, and thongs of neat's leather: the stools are made of wicker work.

Their food is chiefly cheese, butter, and milk, with bread or a sort of suet pudding; they also ent flesh (which they. like half raw); and the fruits they have, walnuts, grapes, apples, almonds, and a sort of indifferent apricot that grows wild. They wash their hands before eating, and generally begin by some kind of grace. They all, of both sexes, drink wine to great excess ; they have three kinds, red, white, and dark-coloured, besides a sort of the consistence of a jelly, and very strong. They drink wine, both pure and diluted, out of large silver cups, which are the most precious of their possessions. They drink during their meals, and are elevated, but not made quarrelsome, by this indulgence. They are exceedingly loospitable : the people of a village come out 
to meet a stranger, take his haggage from those who are carrying it, and conduct him, with many welcomes, into their village. When there, he must visit every person of note, and at each house he is pressed to eat and drink. The Caufirs have a great deal of idle time; they hunt a little, but not so much as the Afghauns ; their favourite amusement is dancing. Their dances are generally rapid, and they use many gesticulations, raising their shoulders, shaking their heads, and flourishing their battle-axes. All sexes and ages dance. They sometimes form a circle of men and women alternately, who move round the musicians for some time with joined hands, then all spring forward and mix together in a dance.

They dance with great vehemence, and beat the ground with much force. Their only instruments are a tabor and pipe, but the dancers often accompany them with the voice. Their music is generally quick, but varied and wild.

One of their characteristic features, is their constant war with the Mussulmauns, whom they hold in detestation. 'The Mussulmauns, indeed, frequently invade their territories in small parties to carry off slaves, and once or twice have undertaken more important expeditions against them. About thirty years ago there was a general crusade (if I may be allowed the expression), against then. 'The Khaun of $\mathrm{Bu}$ dukhshaun, one at least of the princes of Kaushkaur, the Paudshah of Coonner, the Bauz of Bajour, and several Eusofzye Khauns, confederated on this occasion, and met in the heart of the Caufir country; but notwithstanding this success, they were unable to keep their ground, and were forced to evacuate the country, after suffering considerable losses. The arms of the Caufirs are a bow about four feet and a half long, with a leathern string, and light arrows of reeds with barbed heads, which they sometimes poison. They wear also a dagger of a peculiar shape on the right side, and a sharp knife on the left, with which they generally carry a flint, and some bark of a particular kind, which makes excellent tinder. They have also began to learn the use of fire. arms and swords from their Afghaun neighbours.

Vor. II. 
They sometimes go openly to attack their enemies, but their commonest mode is by surprisals and ambushes, and they expose themselves to the same misfortunes by neglecting to keep watch by night. They often undertake remote and difficult expeditions, for which they are well suited, being naturally light and active; when pursued, they unbend their bow, and using it as a leaping pole, make surprising bounds from rock to rock. Moollah Nujeeb saw the men of Caumdaish march out against another tribe. The rich wore their best clothes, and some put on black fillets ornamented with cowry shells, one for every Mussulmaun whom the wearer had killed. They sung a war-song as they marched away, in which were the words, Chera hi, Chera hi, Mallrach, and he learned that when they had succeeded in coming on an enemy unprepared, they set up a loud whistle, and sing a song, of which the chorus is Ushro oo Ushro: on such occasions they put every soul to death. But their chief glory is to slay the Mussulmauns; a young Caufir is deprived of various privileges till he has performed this exploit, and numerous distinctions are contrived to stimulate him to repeat it as often as may be in his power. In the solemn dances on the festival of Numminaut, each man wears a sort of turban, in which is stuck a long feather for every Mussulmaun he has killed: the number of bells be wears round his waist on that occasion is regulated by the same criterion, and it is not allowed to a Caufir who has not killed his man to flourish his axe above his head in the dance. Those who have slain Mussilmauns are visited and congratulated by their acquaintances, and have afterwards a right to wear a little red woollen cap (or' rather a kind of cockade) tied on the head; and those who have killed many may erect a high pole before their doors, in which are holes to receive a pin for every Mussulmaun the owner has killed, and a ring for every one he luas wounded. With such encouragement to kill them, it is not likely the Caufirs would often make Mussulmauns prisoners : such cases have happened when the Caufirs were defending their own village, and they then made a feast with great triumph, and put the unfortunate prisoner to death in much form, or perhaps sacrificed him to their idols. 
'They, however, sometimes have peace or truce with Mussulmauns. Their way of striking a league is as strange as their mode of war. They liill a goat and dress the heart, bite off half, and give the rest to the Mussulmaun; the parties then gently bite each about the region of the heart, and the treaty is concluded.

Though exasperated to such fury by the persecutions of the Mahommedans, the Caufirs are in general a harmless, affectionate, and kind-hearted people. Though passionate, they are easily appeased : they are merry, playful, fond of laughter, and altogether of a sociable and joyous disposition. Even to Mussulmauns they are kind when they admit them as guests, and though Moollah Nujeeb was once obliged to be kept by the other Caufirs out of the way of a drunken man of their nation, he was never threatened or affionted on account of his religion by any man in possession of his faculties.

Buduklishaun, though an extensive country, seems to be but one great valley running up from the province of Bulkh to Beloot Taugh between the highlands connected with the Pamere and the range of Hindoo Coosh. The nearest parts of Hindoo Coosh and Beloot Taugh are inhabited by Caufirs, whose territory consequently bounds Budukhshaun on the south and east, dividing it from the Afghauns and the Cobis of Kaushkaur; on the west are the independent Uzbeks of Koondoor, Taulikaun, and Hissaur, and on the north the Kirghizzes of Pamere and the Taujiks of Shoaghnam, Derwauz, and Wukheeha.

These countries are exceedingly mountainous, and are bounded on the north by a similar country called Kurrategeen, also inhabited by Taujiks, and extending to Kokun or Ferghauna. The King of Derwauz claims descent from Alexander the Great, and his pretensions are admitted by all his neighbours.

The Oxus rises in the north-east of Budukhshaun, flows within its northern border, and afterwards separates it from Hissaur. The interior of Budukhshaun is watered by the Koocha, which joins the Oxus. It is a considerable stream; 
over which there are several wooden bridges, as it is seldom fordable so low as Fyzabad. The part of Beloot Taugh within Budukhshaun produces iron, salt, and sulphur, as well as abundance of lapis lazuli; but the celebrated mines of rubies, which occasion Budukhshaun to be so often alluded to by the Persian poets, are situated in the lower hills near the Oxus. They are not now wrought. The plain country and valleys are fertile, though not extensive.

The inhabitants are Taujiks, and are called Budukhshees; but towards the west are many camps of wandering Uzbelss. The capital is Fyzabad, a considerable town on the Koocha. The present chief is Sultan Mahommed, who I believe is absolute. His revenue is said to be six lacs of rupees (about 60,000l.), and his force from seven to ten thousand men, mostly matchlockmen, a service in which the Budukhshees greatly excel. They are occasionally harassed by irruptions of the Uzbeks of Taulikaun, and their borders suffer from the depredations of the Caufirs; but it is long since they have been disturbed by any great war. Fyzabad was taken, and the whole country nominally subdued, by the vizeer Shauh Wullee Khaun in Ahmed Shauh's time; but he probably felt himself unable to retain possession, for he contented himself with taking some relics, and evacuated the country. Among the relics was the shirt of Mahommed, which in the neighbouring countries was thought as great a prize as the statues taken from Italy by the French were in Europe.

The country of Kaushkaur must be carefully distinguished from Cashgar, near Yarkund, in Chinese Toorkistaum. I have endeavoured to mark the difference by retaining the spelling of our maps for the first place, and giving that which is commonest in Afghaunistaun for the other ; though, in fact, I lave heard both called indiscriminately Kausbkaur, Kaushghur, and Kaushgaur. The resemblance of the names led us into great mistakes when we first arrived at Peshawer. We bought tea, which we were told was brought by caravans from Kaushliaur (Cashgar); and the first people whom we asked respecting the distance told us we might 
easily go to Kaushkaur and return within a fortnight. In time, however, we obtained more precise information. We found that the rearest Kaushkaur was an extensive, but mountainous and ill-inhabited country, lying to the west of Budukhshaun, from which it was divided by Beloot Taugh; having Little Tibet on the east, the Pamere on the north, and the ridge of Hindoo Coosh (which separates it from the Eusofzyes) on the south.

The country is high and cold. The inhabitants live chiefly in tents, though there are some towns. They belong to a nation called Cobi, of the origin of which I know nothing but what is suggested by the resemblance of their name to that of an extensive tract in Chinese Tartary. They are at present Mahommedans, and are under different petty despotisms, to the number, I understand, of four. That to the west is called Chitraul, and has been sometimes invaded from Budukhshaun, though defended by Beloot Taugh and the river of Kaushkaur. Towards the Eusofzyes is Droosh, which was taken by the Afghauns of Punjcora. Another of these principalities is Mastooch; but the whole is little known, especially towards the north and east. Mr. Macartney mentions a road from Punjcora along the borders of Kaushkaur, running up the valley of the river of that name, and practicable for camels. This diminishes the wonder of Kaussim Khaun's passage of the perpetual snow on Hindoo Coosh, which has been mentioned in the account of the Eusofzyes. 


\section{APPENDIX D.}

EXTRACT FROM LIEUTENANY MACARTNEY'S MEMOIL.

I AM well aware of my inability to perform a task of the present kind, but at the particular wish of Mr. Eiphinstone I have attempted it, though I much fear it will be found very imperfect; and from the short stay of the embassy at Peshour, and my time being chiefly employed in obtaining routes, and protracting them on the spot, the general accounts of countries are not so full as I could have wished.

\section{CONSTRUCTION OF THE MAP.}

In the construction of the map particular attention was paid to obtain the correct distance of some grand points, from which more distant ones were afterwards to be settled : this was done by various routes set off from points fixed by observation in the route of the Caubul embassy, and the space contained within these great angles has been filled up, as much as possible, by cross routes, which give the great bends of the road, and of course the position of these points, more correct than by setting off the gross distance.

The windings of the road cannot be laid down with any degree of certainty from the direction given by the natives; $I$ have, therefore, attended chiefly to cross routes forming great angles, to obtain the true bearings of the roads.

The first grand point I thought necessary to fix was Bukhur, situated on an island formed by the river Indus, in latitude $27^{\circ} 30^{\prime}$ north, and longitude $69^{\circ} 20^{\prime}$ east. The points from which I fixed the position of this were Beekaneer, Bahawulpoor, and Moultaun. This was done by taking the mean of several routes from each of these places. The distances were set off in coss, which I found to be a 
mile and a half each, by the run of the perambulator, from Beekaneer to Moultaun. The distance of Bahawulpoor from Moultaun is said to be forty coss, and the perambulator makes it sixty-one miles. I have, therefore, allowed one mile four furlongs to each coss in the routes from these places to Bukhur, and declucted one in ten for winding, agreeable to the nature of the country.

The second grand point I fixed was Caubul. I have good reasons for placing this a very little north of Peshour, first from the bearings with the theodolite from Peshour of Suffaid Coh, which is situnted three coss, or four miles and a half, south of Nimla, on the high road from Peshour to Caubul, and more than half way. It appears that this vil. lage cannot be to the north of Peshour, Suffaid Coh bearing from soutll-west $86^{\circ}$ to $88^{\circ} 30^{\prime}$. This throws Nimla about due west of Peshour; thus far, I think, there can be no doubt regarding the direction of the road, and for the remainder I have three routes from Khugulwala, two from Dera Ismaeel Khaun, two from Kohat, and many from Peshour, all of which meet at Caubul and form great angles : all these points from which routes were taken being fixed by observation, together with the bearings of Suffaid Coll, there can be no doubt but Caubul is near the truth.

I have allowed one mile six furlongs to each coss from all these places, except Peshour, where they are found to be one mile four furlongs, or King's coss ; but from Dera to Kohat I found the coss in geneial one mile six furlongs, and sometimes a little more. This last excess I have allowed for winding, and have set off the full distance of one mile and six furlongs, though the country is hilly; and notwithstanding this, it only throws Caubul four miles north of Peshour: had I deducted more for winding, it would have brought Caubul still further south. In the printed maps Caubul is put north-west of Peshour, but it is eviclent the mistake has arisen in placing Peshour above a degree too far to the southward. Its latitude is $34^{\circ} 9^{\prime} 30^{\prime \prime}$. The coss from Peshour to Caubul is one mile fonl furlongs, being King's coss. The distance from Peshour to Attock, in King's coss, 
is thirty, and by the perambulator it was forty-five miles one furlong. From this I have calculated the distance from Peshour to Caubul, and have allowed one in eight for winding, in consequence of the road being through a very hilly country all the way. These are my chief reasons for placing Caubul as I have; and supposing it to be correct, I take it as a point from which I mean to settle the position of Candahar.

The third point is Candahar. This I have fixed from the following routes: four from Bukhur, which I have fixed, and take for granted is right; two from Dera Ghazee Khaun, which I fixed by cross routes from Bahawulpoor, Moultaun, and Ooch; the distances being short and the angles great, it must be nearly right; one due west, from Dera Ismaeel Khaun by the Gholeree pass, leaving Ghiznee to the right; six from Caubul, and two from the sea from Koracheebundre via Killate Nusseer Khaun, through Belochistaun.

The distance from Caubul to Candahar is set off at a mile and a half to each coss, being the King's road, and the coss has been found a mile and a half each. The others I have calculated by the rate of marching, not lnowing the exact length of the coss in these countries; and having calculated the rate of marching through various kinds of country, I consider it a more correct mode, where the leng th of the coss is not known, than any other: I have found camels march at the following rates, two miles and a half per hour for twelve and thirteen hours : over the sandy desarts they beat the elephants: we had one hour's halt : in fifteen and sixteen miles, they march at the rate of two miles five furlongs per hour over sandy desarts; and when the road was hard and even, they have gone two miles seven furlongs, and for eight or ten miles, three miles per hour, loaded. From these observations I have calculated the march of caravans, allowiug for halts and the nature of the country. The sea-coast I have taken from a printed map, supposing it to be correct. This I conceived to be necessary in fixing some distant points, for it could not be supposed that I could lay down the windings of the coast from information. 
'The fourth grand point is Bulkh, the position of which is well calculated for fixing the following points, viz. Heraut, Bokharn, and Budukshaun. Bulkh is situated two marches from the left bank of the $\Lambda$ mmoo or Oxus, on the great road froin Peshour, Caubul, and Candahar, to Bokhara. I have a great many excellent routes to it from the above places, and the most of them agree; those which I had reason to suppose incorrect I rejected, but from having so many which agree in the places and distances, and the points forming great angles, besides numerous cross routes to correct the distance in the grent curves of the road, I feel grent confidence in plicing Bulkh as I lave.

I shall take this as a point from which I mean to settle the position of Heraut. Candalar shall be the second point. From the great distance of Heraut, and from the Huzaral country, which is generally avoided by travellers, being on the direct road from Caubul to it, the road takes a great curve, and I have founcl more difficulty in placing it than any of the points hitherto laid down. Tlie routes, however, of Zemaun Shauh and Mahmood Shaul from Heraut to Caubul, through the Huzarah country in a direct line, (the former having performed it in eleven, and the latter in thirteen days), have been of great service, witl the routes from Candahar and Bulkh, in fixing its position. Had it not been for these routes I should have placed Heraut much further west, and given a less curve to the road from Candahar. I have allowed a distance of four hundred and eighteen miles from Heraut to Caubul in a direet line, which I conceive to be a full allowance; this gives, in a direct line, thirty-eiglst miles a day, which Zemaun Shauh must have marched; and the country being excessively mountainous all the way, I cannot allow less than one in seven for winding, which gives a distance of forty-four miles he must have marched ench day; this distance for a body of horse and mules, for eleven days together, I think is fully sufficient. It appears from the routes from Candahar to Heraut that the road has a very great bend. There are three roads, one by Furrah, which is west of Candahar and south of Heraut. The 
second by Dilaram and Gurranee, which is the centre road, and has also a considerable curve. The third is called the Sirlud road, and is the most direct one, but it passes through a hilly country of the Tymunees and other Ymaks, and is seldom travelled. All the distances given in these routes make it necessary to give a great curve to the road in order that the full distance may be given, and that Heraut may be by this means brought to a reasonable distance in a direct line from Caubul, for there can be no doubt of Zemaun Shauh and Mahmood Shauh's having performed these marches, it having been heard from so many quarters, and all agreeing within a day. In the routes from Candahar to Heraut, via Furrnh, it appears that the sun rose towards the traveller's back, and set in front as far as Furrah; and from that it rose to his right, and set to his left. The same appears in the routes by Gurranee, and the distance given from Caubul and Bulk $h_{1}$ agreeing to this curve, I think Heraut is near the truth. Had I not placed Furrah at the angle, the following routes would have thrown out Mushud south-west instead of northwest of Heraut; the routes from Furrah to Ghain and Toon, from Ghain to Mushud, from Ghain to Deh Reza, from Del Reza to Jellallabad and Candahar, and from Mushud to $\mathrm{He}$ raut. The road also from the sea-const from Chooabar to Heraut passes through Furrah. There can be little doubt of Chooabar being south of Heraut, and as the road leads by Furrah, it is another proof that Furrah is nearly south of Heraut, and consequently the road has a great curve. Had I thrown Heraut further north, and given a greater curve to the road in order to bring it nearer Caubul, it would have brought it too near Bokhara and Bulkh, which are fixed from other points. I feel perfectly satisfied, from these and many other circumstances, that I have got Heraut correct. I shall now take it as a point from which I mean, to fix the position of Bolkhara, as it forms a great angle with that and Bulkh. The country, however, between Heraut and Bokhara being for the most part a desart, and seldom travelled, excepting by Cafilas, I have only two routes, which, however, agree; and from the very great angle it forms with Bulkh, I have every 
reason to suppose it correct. The routes also from Bokhara to Kokun, and round by Budukshaun, also assist in correcting its position. The routes from Bulkh are numerous, and most of them agree. From Bokhara and Bulkh I have settled the position of Samarcand. The position of Kokun I have fixed from Bokliara, Bulkh, and Budukshaun, which form great angles; and having many cross routes within these great angles, I feel great confidence in placing it as it is. Fyzabad is another grand point of great consequence in the construction of the map, and should have been mentioned before Kolsun, as it is a point from which I have fixed Kolsun. I have been enabled from the following routes to fix this point with great exactness, viz. Bulkh, Caubul, and Peshour, besides numerous cross routes to correct the windings. Fyzabad is the capital of Budukshaun. It is situated on the Kokcha river, latitude $36^{\circ} 10^{\prime}$, and longitude $69^{\circ} 16^{\prime}$, east. I must now fix the position of Cashmeer, which I have been enabled to do with the greatest correctness by the following routes, all of which agree, viz. Peshour, Fazabad, Jelum, and Rotas (of which I have the bearings), Vizeerabad, and Loodeanna, which places are fixed by observation. From this point, Fyzabad and Huzrutimam, I have placed Kashghur and Yarkund. These routes form very great angles, and I have every reason to suppose these places are placed correctly. 'This great angle has been less filled up with cross routes than any of the others hitherto mentioned; but this is accounted for by the greater part of the country being desolate. The whole of the Punjaub I conceive to be nearly as correct as if it had been surveyed, for having marched all round it, and crossed the places from so many points fixed by observations in our march, I think there can be but very little error in their positions. Keech I have fixed by routes from Candahar, Shikarpoor, or Bukhur, Jellallabad in Seestaun, and along the sea-coast from Hyderabad.

From this point and three others I have fixed the position of Khubees, viz. Deh Soollum a hundred and sixty-eight miles, from Hykul two hundred and fifty, and from Toon three liundred and fifteen ; from Keech it is ten days' journey 
for a Coffella at twelve hours a day with camels : all these roads are across the great salt desart. The distance being so great, and scarcely a place occurring on the way, I did not think it worth adding another sheet to the map for these alone. Khubees, by these, falls in latitude $30^{\circ} 40^{\prime}$, and longitude $58^{\circ} 18^{\prime}$. Kirman is three days' journey beyond it, west.

Kilati Nuseer Khaun is another point which I placed from the following routes, viz. Candahar, Bukkhur, Dera Ghazee Khaun, and Koracheebundur. I have been able to fix many nearer points from bearings of snowy mountains. These are the chief points from which the map has been formed, and all these points have undergone further corrections, when it was found, by cross routes within these angles, that the road took some great curve. All these rough copies being made on the spot, I, of course, could find out any errors by the numerous cross routes, and make the necessary corrections by obtaining further information from different people regarding the doubtful parts on the spot; and I conceive it next to an impossibility to make out a map from merely writing routes, and neglecting to protract them as they are obtained. Had I adopted this plan in order to get more extensive information, I could not have placed that dependence in its correctness which I now do; for there are but few places in the map which have not been several times erased, in consequence of some short route coming across, which, of course, corrected their position. A great advantage in this mode is, that the routes forming the greatest angles to the great ones already set off, are immediately seen, and may be particularly inquired for, which could not be done afterwards on protracting the routes, or the necessary corrections made. You can very soon discover whether a man is telling the truth or not, after having some grand points to work from, fixed by numerous routes which agree in distance and places. I have found this the only plan for getting at the truth. There are many points yet unfinished for want of cross routes, which may require further correction, and which I still hope to be able to do. 


\section{FACE OF THE COUNTRY.}

r. THE HINDOO KOOSH, OR GREAT SNOWY RIDGE.

I HAVE found greater difficulty in obtaining the proper names of great ranges of hills and rivers than any other point whatever: but as this range appears to be more commonly known to the north-west by the name of Hindoo Koosh, I shall call it so, though, in fact, it is the particular name for one snowy peak of the ridge ; but with a little explanation, they will know any part of the ridge by this name, from the north of Cashmeer to the hill itself, a distance of four hundred and forty geographical miles. This ridge has an east and west direction for this distance, and appears to wind in the latitude of $35^{\circ}$ north, winding from $34^{\circ} 30^{\prime}$ to $35^{\circ}$. The ridge appears to decrease in height to the westward of this pealk, and the snowy ridge may be said to terminate a little beyond this point, or west of it, for it appears by the routes from Candahar to Bulkh, which pass this point about fifty miles to the west, that the snowy ridge is not crossed, but hills bearing snow for four months in the year are crossed about this latitude. This is certainly a continuation of the ridge, but they appear to decrease in height as they travel west towards Heraut, and even on to Mushud, with, however, a short interruption about Heraut. They do not go to the northward, for the routes from Fyzabad by Bulkh to Heraut, must cross them if they did; and if they went to the southward, the routes from Caubul via Candahar must cross them. I, therefore, conclude the snowy ridge terminates about the above point; but an inferior ridge continues on in the same direction, and may or may not be considered the same ridge. I took the distance of some of the most remarkable penks in the ridge by cross bearings with the theodolite, and found, at the distance of one hundred miles, the apparent altitude of some was $1^{0} 30^{\prime}$, which gives a perpendicular height of 20,493 feet; but, of course, this could 
not positively be depended on for so small an angle and so great a distance. The most trifling error, which might not appear in the correction of the instrument, would here make a great difference. It was, however, so correct, that I have taken the sun's altitude, and the latitude came out within $2^{\prime}$ of the latitude taken with the sextant; and the distance may be depended on, for I had a base line measured of forty-five miles, which gave a good angle.

From Cashmeer to Hindoo Koosh, all the rivers which rise north of this ridge have a north-west course, with the exception of the Indus, or Sind, and Kammall, (these being forced to the southward by other high ridges, which run at right angles to the great one, and all the rivers which rise south of them have a southerly course. This is the strongest proof I can give of its being a very ligh rilge, and it was perfectly white in the month of June, when the thermometer was at Peshour at that time $112^{\circ}$ and $113^{\circ}$. The same thermometer was $26^{\circ} 4^{\prime}$ further south, in the months of December and January, at Mooltaun, in latitude $30^{\circ} 14^{\prime} 30^{\prime \prime}$. This great ridge from the point I commenced at north-east of Cashmeer, has a south-east course running along the heads of the rivers of the Punjaub, passing to the north of Kot Kangra, Bilaspoor, and Sreenuggur, crossing the heads of the Jumna and Granges, after which their course is southerly. This ridge is perfectly void of verdure towards their summits, but their base is well wooded; their summits appear excessively rugged, having wany high and very remarkable peaks, but unfortunately we marched from Peshour at a time when they were not visible, otherwise the exact windings of the ridge from Jellallabad to Sireenugger might lave been got by cross bearings.

\section{THE PAMER RIDGE.}

Though this ridge is inferior in height to the last, the land on which it runs appears to me much higher, for in travelling to the north from the Hindoo Koosh ridge, the ascent appears to be very considerable, and as a proof of it, all the rivers which have their source in this ridge have a 
southerly course till they meet in the high land of Hindoo Koosh, after which they run west and west-uorth-west after joining the Oxus. This river mects the high lands of Hindoo Koosh north-east of Bullih at Huzrutimaum, one degree north of the hills where the fall from them towards the north appears to terminate, and this may be considered the lowest part between the two ridges; but as the rivers which issue from the Pamer ridge have a southern course of from two to three degrees, and those from Hindoo Koosh from one degree to one and a half, and both being equally rapid, I think it is a strong proof that the land of Pamer is considerably ligher than that of Hindoo Koosh; but as the hills which run north of this high land from about west-north-west to enst-south-east (as appears by the routes which cross them at different distant points), are only one day's journey across, and the Hindoo Koosh ridge in many places two days, the latter one may be considered the greatest, though the ridgre on which they run is inferior. This ridge, like the Hindoo Koosh, has unfortunately no general name by which they can be traced and known at different distant points, but from the following routes crossing a high ridge one day's journey across, and covered with snow for the greater part of the year, and at the different points the rivers ruming north and south from them, I can have no doubt of its being one ridge from Alssoo, soutli-east of Khoojund to near Leh or Luddack, where I have lost them. The routes which cross them nearly in the same parallel of latitude, and the direction in which they are said to run, are as follows: from Durwaz, on the banks of the Oxus, to Kokun; from Peshour to Yarkund they are crossed in two routes, and from Yarkund to Cashmeer via Leh, or Luddack, they are again crossed, and form the boundary between Yarkund and little Tibet.

\section{THE BUDURSHAUN RIDGE.}

This ridge runs from north-north-east to soutli-southwest, between the Hindoo Koosh and Pamer ridges; it separates the Oxus from the Kama, or Kashgar river, and prevents the latter from joining the former, which it would 
otherwise do, and runs from the high snowy mountains called Pooshtikhur, the source of the Oxus, south-soutli-west along the right bank of the Kamma river, (forming the boundary of Budukshaun east,) through Kafiristan to the Hindoo Koosh ridge north of Jellallabad, on the road from Peshour to Caubul; and were it not from the valley between Suffaid Coh, south-west of Jellallabad, and the Hindoo Koosh ridge north, this might be considered as one ridge crossing the Hindoo Koosh ridge at right angles; but the distance across being twelve or fourteen coss, it may or may not be considered as the same ridge. I shall give it separately in the account of the Soliman ridge, which joins Suffaid Coh from the south, and the Teera hills at right angles. The Budukshaun ridge appears, from all accounts, to be a very considerable one, and covered for the greater part of the year with snow. The hill of Pooshtikhur is covered with snow all the gear through, and is said to be forty spears in depth, under which is the source of the Oxus. This ridge contains many valuable mines of silver, lapis lazuli, iron, and antimony. The ruby mines are nearer the Oxus, at some distance from the ridge. There are numerous streams issue from it, and join the Oxus and Kamma. In the routes along the left bank of the Oxus, it appears that in each day's journey from two to three streams are crossed coming from this ridge, from fifteen to thirty and forty yards broad, knee and middle deep. The whole of the country between the Hindoo Koosh and Pamer ridges appears to be groups of hills; but it is easy to trace some considerable ranges, from which inferior ones shoot out at right angles, and form these groups and narrow valleys. The hills are well wooded, and the low ones along their base are well stocked with fruit trees of various linds. The country also to the south of the Hindoo Koosh ridge is complete groups of hills for sixty or seventy miles, with valleys of from a gun-shot to two and three miles broad, rich and well cultivated, producing quantities of fruits, grapes, apricots, and pomegranates. These groups decrease in height as they go south, and at the valley. of Peshour they are very small, not above seven or eight hundred feet high. 
IV. 'THE TERRA OR KHYHER RANGE.

Turs range commences a little below the fort of Attocli from the right bank of the river Indus, on the opposite side from the fort, and runs in a westerly direction till it meets the Soliman ridge, south of Sufficic Coli, sepalrating the valleys of Kohat and Peshour, and increases in height as it approaches the Soliman ridge and Sullaid Coh. It applears to me that this ridges crosses the Soliman ridge, and continues with a more soutberly course to Ghiznce. From this ridge there are groups run north and south between it and the Hindoo Koosh ridge north, crossing the great rual (at right angles) from Peshour to Caubul, and forming the western boundary of the valley of Peshour at Jummrooul. From this point they increase in height as they go west, and four distinct ranges may be seen from I'cshour, one rising above the other. From this it would appen that the further range must be of a very considerathle leeight: incled the difference of clinate proves it; for two or three murche's from Peshour, the climate is cool and pleasant, when the heat is intoleralsle at Peshour. The Tcera and Khyler hills are covered with olive trees, but are very rugged, and but few roads through thom passible for lorsemen. 'T'o the westward they produce iron of an escellent quality. I have heard that the salt hills of Karrabagh take a curve up to near their junction with the Soliman ridge.

\section{TIIE SOLIMAN RITGE.}

Tuxs range is of very great extent, and runs nearly north and south. It may be said to begin at Suffaid Cuh, and runs south till it meets the Teera hills north of Pewar; it then runs south-south-east by Kineegoorem to 'Tukht Soliman, from which point they decrease in height consilerably, having no snow south of this point in the enil of January. The Tulsht had an altitule of $1^{\circ} 30$ from Deera Ismaeel Krhan, distant sixty miles, which gives a perpen Licular height of twelve thousand eight laundred and thirty-one feet. From this point their course is suntherly to the lititucle of VOL. II. 
Moultaun, for they were not visible to the south of west from Moultaun. It appears from the routes that they take a deep curve in from the river at this point, and at Shicarpoor are not in sight; but it appears from the routes down the Indus, through the country of the Talpoorees, that they again take a curve towards the river, and they are to the right on the road to Tatta, from twenty to thirty coss all the way; but being unable to procure routes to the southward of Shicarpoor through them in a westerly direction, it was impossible to fix them with any degree of certainty, having only the informant's estimated distance, which may be out for ten coss. These hills to the north are covered with olive trees. They are steep and rugged, and the passes through them are difficult: about Kaneegoorem they produce quantities of a most excellent kind of iron, which makes good swords.

Several inferior branches run from them east to the Indus parallel to the Teera ridge. The first one south of the Teera hills is the salt range, which crosses the Indus at Karrabagh, and runs on to Jellallapoor on the banks of the Jelum. This ridge is much inferior in height to any yet mentioned, but the roads leading through them are rugged and difficult. The whole of the country between this ridge and the Teera one, is groups of hills forming some rich and fertile valleys. They are, however, few. The general direction of the low ridges was from north-west $80^{\circ}$ to south-east $80^{\circ}$; other ridges run north and south, crossing these ridges near the Indus; they appeared equal in height to the Salt Ridge. They are formed in deep groups, steep and rugged. The salt produced in this ridge is as clear as crystal, and so hard that they malke plates of it to eat off. Quantities of it are sent to Cashmeer, and down the Indus from Karrabagh. The next range that comes from the Soliman ridge is from the north of Kaneegoorem, and runs in an east-south-east direction to Punnialla; this range is inferior to the Salt Range, and may be eight or nine hundred feet high. The roads through it are few and difficult. The part near Pumnialla is bare, and appears of a sandy substance, the southern sicle almost per- 
HILLS EXTENDING WESTWARD, ETC. 403

pendicular; and, in climbing up, large flakes came off in laying lold of the clifts ; and it is rather dangerous.

\section{GROUPS OF HILLS EXTENDING EARTWARD FROM THE SOI.IMAN RIDGE DOWN TOWARDS THE INDUS.}

There are two separate ranges of hills run parallel to the great range east of them, extending in some places to within ten and twelve coss of the right bank of the Indus. Those near the river appear to be formed of a sandy substance, the same as the Punnialla hills, perfectly bare. The valleys, however, between these ranges, are rich, and inhabited by Sheeranees, Oosturanees, and Baburs, who plunder travellers; and, in consequence, few routes have been got through them in a westerly direction.

The second low range, which is about midway between the great and small range, appeared to be well wooded, chiefly with the olive tree. These low ridges accompany the great one in all its windings. The average distance of the great one was found, by cross-bearings of different points, to be sixty miles from the banks of the Indus. The valleys, I have been informed, are of very considerable breadth, and there are several springs run from the hills used in cultivation.

\section{GROUPS OF HILLS EXIENDING WESTWARD FROM THE SOLIMAN RIDGE.}

TuE whole of the western side of this ridge from the great road, which leads from Peshour to Caubul, down to the latitude of Kilati Nuseer Khaun, is one complete group of hills, extending in most places from two and a half to three degrees of longitude. The most considerable appear to be those to the northward, extending through the country of the Vizeerees and Soliman khels to Ghiznee, and southerly to the Gholeree pass. From this they appear to decrease in lieight as they go southerly through the country of the Kakurs, though they still appear to retain a considerable height; for many very considerable kotuls (steep passes) are passed to the southward; but it is impossible to trace any regular

$2 \mathrm{D} 2$ 
range. Those which ran through the Kalkur country, extend as far as the great road leading from Kandaliar to Shicarpoor west, and beyond them is the commencement of a great desart. From Ghiznee north they stretch to near Kandahar, decreasing in height as they go westwarcl. From Shuhersuffa they take a curve to the southward, and join the Kakur hills, which you lave to the left, and on the road in some places from Kandahar to Kilati Nuseer Khaun; but near the road they are low.

I mention thesc separately, though they may be said to join the hills west of Caubul and the Huzarahs (for there is. ouly the plain of Mydan, and a narrow valley, from that to Kandahar along the King's high road by Ghiznee, that separates them); but, as the hills north and south decrease in size as they approach this road, they may be considered as separate, for in the whole of this road it does not appear that any ridge is crossed. I shall therefore go on with the $\mathrm{Hu}$ zarah hills north of this road and west of Caubul, but shall first mention more particularly the high land of Ghiznee, which appears to join the Teera hills crossing the Solimanee ones nearly at a right angle. Ghiznee is said to be colder than Caubul, though there does not appenr to be any particularly high hills round it; but it must evidently be placed on ligher land than Caubul, for it appears that a strenm runs from Ghiznee north by Logur and Mydan, and joins the Caubul and Punjsheer rivers. The Turnulk river rises westsoutli-west of Ghiznee, and has a west and south-west course. The Koorem rises east of Ghiznee, and runs east-south-east southerly to the Indus. The Gomul rises south-east of it, and runs south-east. Thus it appears that all the rivers which rise round Ghiznee run direct from it, which is a strong proof it is situated on very high land. The high land of Ghiznee appears to run by the west of Logur in a curve to the Teera hills and Suffaid Coh. It appears also, that, after passing the valley along which the great road from Caubul to Kandaliar leads to the north-ivest of Ghiznee, you agnin meet with very high land, which stretches to the northnorth-west to Kohi Baba, a remarkably high, snowy moun- 
trin west of Caubul. It appents from all accounts that the whole of the country to the right of the roal from Caubul to Heraut west, and extending to the Hindoo Koosl ridge north, a distance of three hundred and sixty miles west, and from two to three degrees north and south, is ane complete group of hills, which are in general very high, and the whole space scarcely passuble for a horseman, and in most places not at all. The hills are well wooded, and have numerous springs rumning from them. The few valleys there are appear rich, and produse quantities of fruits of all kinds.

\section{KOIISTAN, NORTH OF THE CAUBUL RIVER.}

Tac whole of this country, which extends from the Ghoor Bund along the Punjsheer river (which furnishes the greatest body of water, and is joined by the Caubul river), and along these joint streams, having the Hindoo Kooslı ridge to the northward as far as the valley of Peshour, is one complete group of hills, which increase in height as they run from the Caubul river to join the above ridge. The hilis are ligh and rugged, but appear to be well woodex, and the climate is cold. They furnish many springs and streams, which run south, and join these joint streams, afterwarts called the Kama, from a village of that name at the junction of it with the above streams. There are some narrow valleys which are inhabited by Taujiks. The few there are, are rich, and produce quantities of fruits, chiefly grapes, apricots, and pornegranates, but the country cloes not appear practicnble in general for horses.

\section{RANGES OF FILLS EABH OF TEE INDUS.}

The country from the Salt Range which crosses from Karrnbagh to Jellallapoor on the Jelum, in an easterly direction to the northward, is hilly, (particularly that part north of the great road from Attock to the town of Jelum, seven coss from Rotasgurli on the left bank of the river), extending up to Cashmeer in deep groups, and increasing in height as they go north. They are so difficult, that no traveller goes the direct road to Cashmeer, but generally takes the cir- 
cuitous route of Salih Ke Surai, where the great road from Attock to Cashmeer joins. Even this road is excessively difficult, particularly as you get near Cashmeer, having only room for one horseman, with perpendicular rocks on each side. There are several small but rugged ridges, with diffcult passes, run from them to the south-west down the Doab, some of them joining the Salt Range. We had an opportunity of seeing these ranges, and the nature of the passes through them. The first we passed after leaving Attock, near three miles and a quarter $30^{\circ}$ south-east of Kalake Surai, through which a good road has been cut by Shah Jehan, and paved with large, broad, flat stones, a great part of it in perfect order. The range is low, but steep and rocky. The range runs from at north-east $75^{\circ}$ to southeast $80^{\circ}$. This point appears about the lowest. To the east and north they increase in height, and appear steep and rugged; they join the second range of hills south of Hussinabdal, and from thence run west towards Nilab. They are covered with a low bushy jungle. I went up those to the east of the pass, and found them very rocky and difficult, and this appeared the easiest point. The whole of the country between the ranges is excessively uneven with rising ground, in many places much cut by torrent courses, and quantities of jungle, and deep ravines; in most places the soil sandy, and a quantity of loose stones over the surface. There are some rich plains, which produce grain in great abundance, but even they are much cut in many places by torrent courses from the hills.

The second range was the Neela hills, twenty-five miles north-north-west of Jellallapore Ghat, on the Jelum. The pass through this range was very difficult, and above five miles through, it winding along the bed of a nullah, or torrent course, with high perpendicular rocks in many places on each side close; a fort on the south side of the pass, built by Ootum Sing, about half way through, commands it, and duties are collected from merchants. This pass is by nature very strong, and might be easily guarded; and I am told it is a better road than the King's one, which leads direct from 
Rotasgur to Rawilpindee. Fourteen miles south-south-east of this pass, we passed the south-west point of the Tilla hills, which run to Rotasgur. The road round their point was along the bed of a torrent with high and rugged banks, and broken ground to the right, which extends to the Salt Ridge, distant six or seren miles. After passing the Tilla hills, a deep group of lower hills, equal to the Salt Ridge, commences, and extends to the banks of the Jelum, having them at the distance of one mile and a half to the left of the road. $\Lambda$ mile above Jellallapore Ghat, the Salt Ridge meets this one in a curve, and the road leads out of the valley between them down a steep and rugged bank to the Ghat, the latter part being along the bed of a torrent, which carries off the water from the valley we have just left.

All these ranges join the deep group of liills to the northeast, but none of them cross the Jelum below the town of Jelum. The deep groups do, however, cross there, and run on by Bimber, Jumboo Nurpoor, and down by the south of Bilaspoor, crossing the Jumna at Fyzabad, and the Ganges at Hurdwar. The whole course from Jelum is as near southenst as possible. They increase in height gradually to the snowy ridge north, and appear to form regular ranges running parallel to each other; but they are, in fact, deep groups, increasing in height as they run north-east.

\section{TABLE-LAND OF LITTLE TIBET AND THE HILLS EXTEND-} ING NORTH-WEST TO YARKUND,

IT appears that after five days' journey north-east of Cashmeer an evident ascent commences, which isvery great for three or four days' journey, after which it is less on to Leh. The ascent continues even on to the great ridge which separates Tibet from Yarkund, as appears by the course of the stream which comes from that point. This ridge is the one I lave before mentioned, as having been passed at several distant points, and answers to the Pamer ridge. The road from Leh leads along it for twelve days' journey on the road to Yarkund, and is crossed fifteen days' journey from Leh, at which place the above stream is left, and has probably a more distant source. 
The country to the left was also very mountainous, but perfectly desolate, and on this account but little more information has been obtained regarding the nature of it. It appears, however, from a route from Deer, passing from west to east through the southern part of this country, that the whole road was excessively mountainous, and I think there can be little doubt of the rest being of the same nature.

I shall now endeavour to give an account of the rivers; any hills which I may have omitted in this general account, will come in in the separate accounts of each country.

\section{RIVERS.}

\section{THE RIVER AMMU, OR OXUS.}

Tris river, from its source to the country of Durwaz, is better known by the name of Punj than Ammu. It has its source from the high lands of Pamer. It issues from a narrow valley two or three hundred yards broad in Wukhan, the southern boundary of Pamer. This valley is enclosed on three sides by the high, snowy mountain called Pooshtikhur, to the south, east, and west. The stream is seell coming from under the ice, which is stated to be at least forty spears in depth. The spring itself could not be seen in consequence of the great mass of ice formed over it, but there can be no doubt of the spring's being on this hill under the ice, for it does not appear that there was any open or break in any of the three sides mentioned by which it could come from a more distant point. I, therefore, conclude that this is the true head of the Oxus; at all events, the greatest body of water, though there are others which may have a more distant source. It is carried north in this narrow valley for five coss; at four coss it is twenty yards broad, and breast-deep; and on leaving the valley, after having been joined by many other springs from the same hill, it is fifty yards, and middle deep. The Shiber, or Adum Koosh, joins it five coss above Killa Shah Jehan, twenty-five coss below Pooshtikhur. This river, crossed five coss above the junction, was middle deep, 
and sixty yards broad, so that the Punj, or Ammu, was nearly equal to it at the distance of five coss from its source; and having twenty ooss further to run before its junction with the Shiber, it must have attained a very considerable size, particularly as it appears that seven or eight streams from knee to middle deep, and from ten to thirty yarcls broad, joined it in this distance from the left bank. I think there can be no doubt of its being much larger than the Shiber at their junction, and it appears well ascertained that the Ammu bears the name Punj for a considerable distance from its source. The place has been seen by two people, who gave the same accounts, and I have heard it from several who did not see it, but had heard that it rose in the valley of Wukhan, or from the high, snowy mountain of Pooshtikhur. I have routes which run east and west of this point to Yarkund in a northerly direction, and meet to the north of this point, leaving it within the angle. If this stream had a more clistant source, one of these two routes must have crossed it, which it does not appear they did.

The road to the left or west, crossed the Shiber five coss from Killa Shab Jehan, which was the only stream of any con-. sequence crossed up to the junction of the two roads. The road to the right or east passed Pooshtikhur about forty coss to the right, leaving it to the left. 'The road appears to lead along the Kashgar river, or Kamma, to this point, and nothing but rivulets were crossed up to the junction of the western road, which left Pooshtikhur to the right. It is eviclent from this that the Punj must have been crossed, had it a more distant source.

I shall here leave its souree, and follow it in a south-southwest direction for a hundred and twenty miles, where it meets a high ridge of mountains running from west-north-west to east-south-east; from this point it takes a west-nortl-west course along the north side of this ridge through the countries of Shooghgnan, Durwaz, and Kurategeen, where it finds vent through this ridge, and passes through it to the southward, following a southerly course till it meets the high land which extends from the Hindoo Koosh riclge at Huzruti- 
mam. Thus far, a distance of more than three hundred miles, it is confined between hills, and is joined by innumerable streams, from two to four of which are crossed in each day's journey along its left bank, from ten to thirty yards broad, and knee and middle deep, besides two very considerable rivers, viz. the Soorkhab or Kurategeen river, and the Kokcha or Budukhshaun river. I have unfortunately no routes from Durwaz along its right bank to Klila Shauh Jehan, and consequently have not been able to ascertain the streams which it must receive from the northward in this distance. They must be more considerable than those from the southward or the high ridge of Budukhshaun, as the high land of Pamer, which gives rise to so many great rivers running fiom west to east, is to the northward of this space. I imagine many more streams must join it, but luave been unavoidably left out for want of further information. From Huzrutimam its course is west-north-west northerly to Bokhara, a distance of two hundred and fifty miles; it appenrs to be forced off in this direction for some distance by the high land of Hindoo Koosh, which extends north of the ridge a considerable distance, and runs over a flat country, sandy and little better than a desart. I have a route from this point to Oorguni, along its banks, which gives a distance of four hundred miles, over a desart for at least three hundred miles, with only a few habitations of horse-breeders along the banks in different places. There appears to be a forest on from the left bank the greater part of the way, and travellers are obliged to carry provisions for eight or ten days at a time. At Oorgunj, my informant left the banks of the Oxus after crossing it on ice. Oorgunj is on a branch of the Oxus, situated eight coss from the main channel. From this he travelled to the north-north-west, passing the towns of Toorbut, Sugger, and Lulughan, on to the city of Kheeva, situated on the banks of a large river called the Neelum, nearly as large as the Oxus, and which joins a large lake some days' journey further on. This I take to be the lake of Aral. The Oxus, I have been informed, also empties itself into it, but of this I have obtained but little information. I have only one 
route along the Oxus, and would not venture to put it down, having no others to corroborate it, ol cross routes to correct the direction. Having traced the Oxus nine hundred and fifty miles, from its source to New Oorgunj, I shall give a sketch of the principal rivers which fall into it. First, the Shiber, or Adum Koosh. This river has not been traced, above the point where it was crossed, five coss from its junction. It was at that point sixty yards broad, middle deep, but so rapid that few men could ford it ; my informant says he crossed it on a cow, which is the common mote, and that they stand the current and keep their feet much better than a horse; he says a horse could not stand the current. The cows used for this purpose were very strong, and had long bushy tails.

Second, the Soorkhab or Kurategeen. This river rises in the Pamer ridge, and after a course of a hundred and eighty miles, empties itself into the Oxus, thirty miles above the junction of the Kokcha on its right bank. This river receives many streams in its course, besides the Suffeekun and Wukheeha rivers. It runs through the country of Kurategeen, and ten coss above its junction with the Oxus it is not fordable, being crossed on mussuks or leathern bags: at this point it is called by a different informant the Kurategeen river, but I imagine its proper name is the Soorkhab. Its course is through a very mountainous country.

\section{THE KOKCHA OR BUDUKHSHAUN RIVER.}

This river rises in the Buduklishaun ridge, south east of the capital, Fyzabacl, forty-four miles. At ten miles east of the town, it receives two streams equal to itself, and they pass close to the town in one stream. There is a bridge across the river at the town. It is very rapid and not fordable; its course is a hundred and thirty miles in a west-northwest direction, and it joins the Oxus above the village of Khajaghar with such force that its stream crosses to the opposite bank of the Oxus. It passes through a hilly country for the greater part of its course, and receives several streams from the northward. 


\section{THE AKSURRAI.}

This is formed by the Ghoree, Bungee, and Furkhar, which join five coss north-west of Koondooz; the joint streams of the Bungee and Furkhar passing to the cast of the town, and the Ghoree to the west. These rivers are formed by numerous other streams. The Ghoree rises from three different points in the Hindoo Koosh ridge, all of which join above the village of Kailgah : from their source to Koondooz is a hundred miles, where the name is lost in that of the Aksurrai. From Koondooz to the junction with the Oxus is forty miles. The whole course is northerly, and they join below Huzrutimam about eight or ten coss. The Furkhar rises in the high land south of Fyzabad, or the hills which separate Budulishaun from the Kafirs; and the Bungee, which is equal to it, rises in Durra Turring. They join ten coss below Talikan. 'Their course is equal to that of the Ghoree, which they join as before mentioned. After the junction of all these rivers, the stream must be a very considerable one: it is not fordable, but all these rivers separately are. Their course is through a mountainous country, but containing many excessively rich and fertile valleys, producing all kinds of fruit in the greatest abundance: from the accounts I have got of this part of the country, the valleys appear to be a complete garden.

\section{THE HISSAR OR KAFIRNIFAN RTVER.}

Thrs river rises in a high ridge of mountains which runs from the Paner ridge south, and separates Bolkhara from Kuretageen, east and west. Its course is south-south-west, running through the Kuretageen country and Hissar for sixty miles; it joins the Kurratale river above Regur and below Hissar Bala. The Kurratuk rises in the same hills, and has a south-east course to the junction. From this some call the joint streams the Hissar, but I think improperly, for the joint streams should retain the name of the largest river, which is the Kafir Nihan; and from a route which crosses it a little above its junction with the Oxus, it is called by this 
name. From Hisar to Trmooz, above which they join the Oxus, is seventy miles.

THE ZURRUTSHAN.

ThIs river has its source in the same mountains as the rivers last mentioned, but on the western or opposite side to them. A great branch of this river formerly ran past the town of Sheeraz, twenty-four miles north of Samarkand, but for many years the whole has run past Samarkand north of it three coss in a westerly direction, and since that time the town of Sheeraz has been desolate; this place of course cannot be mistaken for the famous Sheernz in the south of Persia. This river has a much longer course than any yet mentioned as falling into the Oxus, lut nothing like so great; a body of water, being forclable all over, excepting when the snow melts. From its long course over a sandy country, the greater part of it is soaked up before it reaches Bolhara, and at this point there is scarcely any stream at all. It falls into the Oxus two marches west of Bolkhara after a west-southwest course of two hundred and eightly miles.

THE MURGHAB RIVER.

Rises in the Huzarah hills north of the continuation of the Hindoo Koosh ridge, and south of Mymuna: it is calried west, confined between hills for seventy miles, when it passes to the north, quitting the hills and passing over a desart country for about two hundred miles, joins the Oxus three marches west of Bolhara. This, however, is only heard by my informant, and may be wrong. It appears, however, very probable, for it is crossed two marches from the left bank of the Oxus on the road from Boklara to Heraut via Mour, and it is probable that it joins the Oxus not far from this point, which is also stated to be the case by the man who gave this route.

The course of this river from its source is two hundred and screnty miles. Its breadth in the cold season is from fifty to seventy yards, and two feet and a half deep. 


\section{THE RIVER SIRR.}

I HAVE been informed that this river joins the Oxus about one hundred coss west-north-west of Bokhara; but this cannot by any means be depended on, and very little information has been obtained regarding the course of this river. Its course is to the south of west, it being crossed by the Russian caravans north-north-west of Bokhara four or five days' journey, and the distance would give it about that course. From Kokun I liave got four days' march along its left bank from Khoojund to Kokun. It is said to be larger here than the Indus, and smaller than the Oxus. A stream joins it near Kokun, which rises south in the Pamer ridge, and runs north seventy miles to its junction. At Kolcun it divides in to two branches, and passes the town east and west.

\section{THE RIVER SIND OR INDUS.}

I AM sorry to say but little information has been obtained regarding the source of this river, though some great branches have been traced for a very considerable distance, but not to their source. It appears there are two great branches join al: the town of Dras, eight days' march of a caffilla, north-northeast of Cashmeer. The left of these branches was seventy yards broad a little above the junction, and excessively rapid; a wooden bridge was thrown across it at this point; it came from the north of east, and ran off west, after being joined by the Leh or Luddakh branch: and my informant says he heard it joined the Abba Seen at Bullai. This I take to be Mullai on the Indus above Attock, of which I have had other accounts, and he also heard that it was three months' journey to the head of this branch: but this cannot be depended on; and it is the only information I have got regarding this branch, and it certainly appears to be the main one. Other accounts agree that Dras is eight days' journey for a cafflla north-north-east of Cashmeer, but they differ in some degree regarding the junction. A Cashmeerian informed me that these branches joined two marches above Dras, and that at or below Dras it divided into two branches, the lesser one run- 
ning south to Cashmeer, and the greater one he knew nothing about, but that it was called the Great Sind, and the one which joins the Bedusta at Cashmeer, the little Sind. This latter account appears to me very correct; and as a further proof, I have a route from Deer in Punjcora, north-west of Peshour, which takes a curve from east-north-east to southeast to Cashmeer, by which it appears that the Sind was crossed seven days' journey before they arrived at Cashmeer, and this point must have been north-west. This agrees with the other accounts, and would throw Kot, the point at which the Sind was crossed north-west of Cashmeer, alout one hundred miles west-south-west of Dras, which agrees with the first accounts of these joint streams running off west from Dras. In the first account it does not say that a branch breaks off from the great one, but this might be easily omitted; and it appears from other accounts that a river comes from the northward into Cashmeer, and is called the Lar by some from its passing through a district of that name in the valley of Cashmeer, but its proper name is the Little Sind, which Mr. Forster also mentions. The Luddalsh branch has been traced to a great distance to the south-east. This branch is also joined by another from the north-west, along which the road to Yarkund leads for fifteen days' journey, as has been before mentioned. These marches $I$ have reckoned at eleven and twelve miles a day, as it is through a hilly country, and the cafflla generally arrived at their ground of encampment by eleven or twelve o'clock, and marched after sun-rise; it was also stated to be seven or eight coss a day. They crossed the Pamer ridge to the right, and they left this stream, which I have heard came from a lake in Pamer, and from its direction being south-east by east, I imagine it comes from the lake of Surik Kol, as the direction of its course and accounts agree to this lake. This, however, is only a supposition of mine.

The Leh branch has been traced much further, and is larger than the north-west branch, but smaller than the Dras or left branch. It appears that fiom Leh to Rodack, a place whence wool is brought to Cashmeer for making 
shawls, the road is along this branch twenty-five days' journey for the merchants who bring the wool; but as it is brought on sheep, and as the country is hilly, I cannot allow more than ten miles each day (two hundred and fifty miles): four hundred miles to the fort of Attock, and seven hundred to the sea, total one thousand three hundred and fifty miles. The Indus is confined between high mountains to Torbela, forty miles above the fort of Attock east-nortl-enst, where it enters the valley of Chuch, spreading and forming innumerable islands to the fort of Attock, where it again enters between the hills, and is at the fort only two hundred and sixty yards broad, but deep and rapid. It rises to the top of a bastion at tive edge of the water, which appears to be thirtyfive or forty feet high, but does not spreacl above fifty yards more. It enters a plain five miles south of Attock, and is again confined between hills at Nilab, ten miles south of Attock, and continues to wind among deep groups on to Karrabagh, latitude $33^{\circ} 7^{\prime} 30^{\prime \prime}$, where it enters the rich valley of the Esa Khels in four great branches, and is not again interrupted in its course by hills. From this point to Mitten da Kot, where it is joinerl by the five rivers of the Punjaub in one stream, here called the Punjnud, its course is nearly south and from that to the sea it may be south-south-west, passing through the country of Sind. We crossed the Indus at Kaheeree Ghat, latitude $31^{\circ} 28^{\prime}$, where the breadth of the Ghat at two points was found to be one thousand and ten and nine hundred and five yards, on the 6th of January 1809. At this season it must be at the very lowest. The depth of the deep part of the channel, which was not one hundred yards, was twelve feet; an elephant ten feet and a half high had not one hundred yards to swim, but the main channel here was considerably reduced by several large brauches, which had separated from it, and run parallel to it: one from its right bank was fordable only in a few places, having boats at many of the Ghats, and its breadth was two hundred yards: we forded at a place three feet and a half deep, and fire hundred yards broad diagonally; another con- . siderable branch, fifty yards broad and three feet deep, wras 
crossed before we came to the left bank of the main channel, besides two other inferior branches. The banks of the Indus are very low, that is, the inner barnks seldom exceed six feet, and generally four and five, but in the rainy season it spreads in many places from ten to twelve coss. It appears evident that the main channel formerly ran further to the enstward by seven miles, and the Lya Nullah at present occupies its former bed; for the high banks at Mahommed Rajin, and Kuror or Laleesan, and all along the left of this Nullah at, some distance, has every appearance of it.

The flat country and islands, which are overflowed in the hot season, are excessively rich black clay, well cultivated in many places, and others are overgrown with high grass jungle. The labourers have temporary huts erected, and cultivate the land. The bed of the Indus is sand, with a small quantity of mud, and its water appear's to resemble that of the Ganges. There are many quicksands, and the islands are for the most part covered with long jhow jungle. For fifty coss above Mittendakot, where it receives the rivers of the Punjaub, it runs nearly parallel to them; and at Ooch, which is forty coss up, the distance across is not above ten miles. This space is one complete sheet of water in the months of July and August, and the villages are only temporary, with a few exceptions. The whole country to $\mathrm{Hy}$ derabad through Sind appears to be the same, but there appears to be a quantity of rich land uncultivated, and overgrown with jhow and grass jungle. It appears by the routes along its left bank to Hyderabad, that there are many considerable towns and numerous villages, and in many places canals carried to them from the river. It is rather odd that there should be scarcely any trade carried on between the northern countries and Sind. There is a little between Moultaun, Bahawulpoor, and Sind. I shall now endeavour to give an account of the rivers which fall into the Indus. The great branches to the northward of Cashmeer have been mentioned, and I shall pass on to the Abba Seen.

VOL. IT. 
THE ABBA SEEN.

There appears to be a difference of opinion regarding this name; some think the great branch which $I$ have mentioned as coming from Dras is called the Abba Seen, but $I$ have heard otherwise, and have routes from Peshour and Attock to the source of what I have heard called the Abba Seen, which may, however, be wrong; but I have no proofs to the contrary, and what information I have got I shall state. The route from Peshour to this point is along the Swad river, which had its source from the same hills. The hill from which the Abba Seen issues is called Son Chukesur, the bearing of which from Peshour was north-east $34^{\circ} 30^{\prime}$. This spring is called at the place Sire Abba Seen; the hill is one of the Hindoo Koosh snowy ridge, and its altitude was $1^{\circ} 30^{\prime}$, and by the cross routes from Peshour and Attock to it, which forms a good angle, and agrees with the bearings, it was one hundred miles distant. The route from Attock leads along the right bank of the Indus, by Mullai, to this point; it appears that the river is not fordable at Mullai, that boats or rafts are used; it is four short stages from this to the head of the Abba Seen. The first stage it is fordable, which convinces me that some considerable stream must have joined from the left bank on this march from Mullai, and I have not the least doubt of its being the Dras branch ; but my informant never travelled up the left bank, and could not say; but from the river's decreasing so much in this stage, I think the above branch must have joined the Abba Seen a little above Mullai. I have many routes taken from the same man who gave these, which I have afterwards marched, and in the accounts and distances $I$ found him perfectly correct, and I have every reason to believe that his information on this point is correct also. The Sheesha river rises on the north side of this hill, runs west, and joins the Kama. The hills and valleys about this point produce gold dust; he did not travel further north. 
THE KAMA RIVER.

I round it impossible to obtain the true name of this river, and $I$ think this cannot be its proper name, for it is merely called so from a village of that name at the point it receives or joins the joint streams ' of Punsheer, Ghorebund, and Caubul, a short way from Jellallabad, on the road from Peshour to Caubul. To the north it is called the Kashgar river, on account of its passing through that country; when it reaches the valley of Peshour, it breaks off into three great branches, which join again. Each of these branches has a separate name, and it does not retain one name for four marches together. The greatest and most distant branch rises in the high lands of Pamer, not far from Pooshtikhur, the source of the Oxus, and, after a course of three hundred and eighty miles, joins the Indus three miles above the fort of Attock.

In its course it receives several very considerable rivers, viz. the Punjsheer and Ghorebund, which join below Chareekar, north of Caubul. These joint streams receive the Caubul and Logur streams a little further down, and run parallel to the road from Caubul to Peshour, north of it. At the village of Kama these joint streams meet the above branch coming from the north. From this to the valley of Peshour, the joint streams are better known by the name of Kama than any other. On entering the valley of Peshoul at Michnee, it breaks off into three great branches, which join twelve miles farther down, at Dobundee, the most northern or left branch receiving the Swad and Punjcora in one stream two coss above Hushtnugger, five from Dobundee, and fifteen miles north-east of Peshour. I saw all these streams in one below Dobundee; they appeared about three hundred yards broad, and deep : boats at the Ghat. I went to the centre one of these branches north of Peshour. The first one was up to the saddle-skirts, four feet broad, and stony bottom, in most places very rapid; my horse could scarcely keep his feet; but this was in the beginning of May, when some of the snow water had come down. The 
second branch I attempted, but could not ford; but there are fords, and in the cold season it is fordable all over, except one place, where it is confined between hills. The Punjsheer and Ghorebund are very considerable strenms. The Ghorebund rises with the Hindoo Koosh peak north of Bameean, and the Punjsheer fifty coss east of it, from the same hills. Their course to their junction with the Kama is one hundred and eighty miles.

The Caubul stream, which is only eight or ten yards broad, rises in the snowy hill called Kohibaba west of Caubul; it joins to the Ghiznee and Logur streams east of Caubul, but the most of its water is expended in the cultivation round Caubul and Mydan.

The Swad and Punjcora rivers rise in the same ridge, and are called by the countries through which they pass. Their course is nearly equal, one coming from north-east, and the other from north-west. The name of Punjcora is lost in that of Swad at Tootkan Mutkunnee, below which they unite, and pass to the south by the west of Hushtnuggur, at the distance of two coss, and join the left branch of the Kama, as before mentioned. Their course is about ninety miles to this point.

THE GHUR SHEEN.

Trrs is a very small river, and does not deserve the name. It is two feet deep, thirty yards broad, a clear stream, with a strong bottom, and high rugged banks. It rises east northeast of Khanpoor, twenty-five miles in the hills which run up to Moozufferabad. It runs eighty miles west-south-west, and joins the Indus two coss above Nilab. It is joined near Hussin Abdal by the joint rivulets of Hussin Abdal, and Kala Pawney, and Wah.

\section{THE SWAN RIVER}

RISES in the same hills more to the eastward, but I have not heard the exact point. Its course is about one hundred and thirty miles to where it joins the Indus, eight coss below Mukkud. Its stream is small in the cold season, not more than a foot of water, but in the rainy season it is broad and 
excessively rapid. When it rises to four and four feet and a half high, it is not impossible to cross it; but it rises and falls suddenly. We crossed it where it was about three or three feet and a half deep, and then several camels were carried down. Its bed is sand, with a few stones in the stream; it has many quicksands, and its banks are steep and rugged, with many deep ravines extending in many parts in from its banks. After we had crossed it, it rose more, and was not fordable for three days. This is the case with most of the rivers in this Doab, and some $I$ have seen rise seven or eight feet in less than balf an hour, from having no water at all, merely torrent courses.

\section{- THE ROORM RIVER}

Rises twelve niles south-west of Huryoob, enst-uorth-east of Ghiznee, and, after an east-south-east course of one hundred and fifteen miles, joins the Indus three miles east-south-east of Kagul Walla. The bed of this river is broad, at the point we crossed it, three furlongs and a quarter; but the strean was small, not more than one foot water; its bed was sandy, and had some quicksands. The descent of its bed was very considerable, and when the snow melts it must be very rapid. There are several canals brought from it into the Eesalkhel valley, which has reduced its size at this point. It is joined by the Gombeela at Lukkee: from this to the sea I have not heard of any rivers joining the Indus on the right bank from the westward, nor on the left bank, with the exception of the rivers of the Punjaub, which join it at Mittanda Kote, in one stream called the Punjnud. These rivers I shall give separate accounts of, beginning from the west.

THE JELUM, BEHUT, OR VIDUSTA (HXDASPES).

Thrs is the second largest of the Punjaub rivers. We crossed it in July, but it had not attained its full height; I was told it rose seven or eight feet higher in August. It measured, from edge to edge of water, one mile, one furlong, thirty-five perches. The soundings, in crossing the deep part 
of the channel, which did not exceed two hundred or two hundred and fifty yards, were as follows, in feet, $9,10,11$, $12,13,14,14,13,12,11,10$.

The deep part was towards the left bank; its bottom, sand, with a small quantity of mud. There are many islands and sand-banlss formed in its centre, and it contains many quicksands; its left bank is particularly low, and it must, at its greatest rise, overflow four for five miles of the low country on its left bank.

It rises in the south-east corner of the valley of Cashmeer, is there called the Vidusta, and passes through two lakes east and west of the town of Cashmeer. It is joined six coss below the town by the little Sind; it is joined by many small rivulets in its course through the valley and hills, which it enters at Baramoola; and two coss bolow Moozufferabad it receives the Kishungunga from the northward. Its course, thus far, is nearly west. From this it takes a great curve to the south, and near Jelum it is little lnown; the country being so excessively mountainous, few travellers ever pass that way. The Jelum, in its course through the hills, is very rapid, and from one to two hundred yards broad. I have only one route from Jelum to Moozufferabad, along its right bank, and some of the places appear to be misplaced in the commencement, which I had an opportunity of correcting for thirty coss ; but the same being probably the case in the remaining part of the route, I have not put it down, though the distance agree. The whole road is stated to be scarcely practicable for a man on foot, being through hills all the way. The Jelum is not fordable at any season, though in many places nearly so, as men and horses cross with ease, having only fifteen or twenty yards to swim. After a course of four hundred and fifty miles it joins the Chunab at Trimmoo Ghat, ten coss below Jhung and fifty above Moultaun, in which it loses its name. These joint streams, called the Chunab or Chunha, receive the Ravee twenty-six coss lower down, near Fazilshah and Ahmedpoor, from the eastward, and pass four miles and a half north of Moultaun, retaining the name of Chunab to within four' coss of Ooch, where they 
are joined at Sheeneebukree, by the Gharra, or joint streams of the Beyah, or Beas, and Sutluj, fifty-eight coss below Moultaun, and thirty-two below Bahawulpoor. From this point to Mittenda Kot, where they fall into the Indus, fortyfour coss, these five streams in one take up the name of Punjnud. The Indus and Punjnud, run nearly parallel to each other for this distance ; the distance across from Ooch being only seven coss ten miles and a half. The whole of this space is one complete sheet of water in the rains and hot season, and appears as one river. This might possibly give rise to the mistake in the maps formerly published, in making the Gharra join the Indus, instead of the Chunab or joint streams of the Chunab, Jelum, and Ravee, for the waters of them and the Indus mect for some distance above the junction of the Gharra"with them.

The greatest breadth of the Doab, between the Jelum and Indus, appears to be at the point we crossed it, from Attock to Jellalpoor Ghat on the Jelum a hundred and fourteen miles horizontal distance, and from Moultaun at Raj Gliat to Udoo Kot (seventeen miles from the Indus) was thirty-three miles. The northern part of this Doab, from $33^{\circ} \mathrm{up}$, is hilly, and to the southward is a desart, with the exception of a few miles in from the banks of the rivers, which are overflown and rich.

\section{The ChUNAB (ACESINEB)}

Is the largest of the Punjaub rivers ; it measured at the Wuzeerabad Ghat, on the 31st of July, one mile, three furlongs, and twenty perches, from edge to edge of water, and the soundings were the same as the Jelum, fourteen feet the greatest, but the current was more rapid by a knot and a half; the Jelum is four, and Chunab five, or five and a half. In the dry season its channel does not exceed two hundred and fifty, or three hundred yards; the second channel, which was much the broadest, I am told is dry in the cold weather. There are many islands, and sand banks formed towards its centre, and the measurement was taken between two of these, as at the Jelum. The size of these rivers may be easily calculated for the cold senson, for the joint streams of the Jelum, 
Chunab, Ravee, at Raj Ghat, near Moultaun, were five hundred yards, and the greatest depth seventeen feet: but this was only for one throw, and the average may be eight, or eight feet and a half, for from this it shelved to nothing : allow two hundred and thirty yards for the Jelum, by eight feet, and two hundred and seventy for the Chunab, by eight feet; and the remaining part by five hundred for the Ravee, for I do not allow the Ravee to be more than four feet deep, and a little more than a hundred yards broad; this may be about their average size in the middle of December, the time we crossed their joint streams, agreeable to their breadth and depth in the rains. I allow by this calculation that these rivers must have risen three arid a half or four feet, leaving ten or ten feet and a half for the centre of their channels for the cold season, which I think may be pretty near the mark. I have not heard of any ford on this river below the hills; but, like the Jelum, it is easily crossed at the points where its banks are low and its bed broad, there being only a short distance to swim in the centre. I have heard of the joint streams of the Jelum, Chunab, and Ravee being forded by a camel below the junction of the Ravee; but if this be the case, it must have spread at this point considerably. The banks of the Chunab above are low, but well wooded, as is the Jelum; but the timbers are small, and the wood used in building and making boats is flonted from the hills seventy and eighty coss higher up, where it is in great abundance. The horizontal distance from Jellalpoor Ghat to Vizeerabad Ghat, across this Doab, is forty-four miles. The country excessively low, and soil rich, chiefly pasture.

The following is a list of boats and Ghats up and down the Jelum and Chunab to the right and left of the Ghats we passed. On the Jelum; Mungla four boats, Jelum twenty, Segonia ten, Russoolpoor and Dadopoor five, Jellalpoor and vicinity twenty-five, Pindi Dadun Khaun and vicinity forty, Almedabad and Bhera twenty; total, a hundred and twentyfour in the distance of seventy-five or eighty miles : on the Chunab above Vizcerabad and at it, Vizeerabad twelve, Sodra three, Deena Monja two, Maraj Kakot two, Noushara 
three, Koolowal two, Jinda Behadoorpoor five, Kholasake Chunee two, Kanne Ka Chuck four, Aknoon seven, total listance up thirty coss, forty-two boats; down from Vizeerabad, Ranua Khaun two, Sullooke two, Ramnugger twentyone, Morad four, Wannuke two, Menhdeeabad two, Bhuttee Kachuch Jellalpoor four, Khadirabad Ghat six, total eightyfour in the distance of fifty-five coss. The course of the Chunab, from the snowy mountains to which it has been traced to Mitten ka Kot, five hundred and forty miles.

\section{The RAVEe (Hydraotes)}

Is the least by far of all the Punjaub rivers; its measurement from edge to edge of water was only five hundred and thirteen yards, 12 th of August, when it should have attained its full height: its channel is very narrow. I had only two throws of the lead in passing it, twelve feet. The bottom has a good deal of mud, much more than any of the other rivers; one-fifth may be mud, the remainder sand. The deep channel could not have exceeded in breadth thirty or forty yards, the remainder was from three to five feet, and two or three throws eight or nine feet: in the cold senson it is fordable all over, not above four feet deep. There are many quicksands, and its banks are low and well wooded. There are but few boats on this river, but those there are are good, and much the same as are used on the Jumna. The Indus, Jelum, and Chunab have the same kind of boats, which cross from ten to twelve horses.

The distance from Vizeerabad Ghat to Meannee Ghat on the Ravee, fifty-five miles horizontal clistance. This Doab is rich and flat, but higher land than the last, and the soil not so very rich. The course of the Ravee is very considerable, but I am not quite certain of its having the full course I have given it to its junction with the Chunab, of four hundred and fifteen miles; it appears, however, by a route from Cashmeer, through Kishtwar, that after crossing the high ridge into Kishtwar, the road leads all the way from this point along the banks of a stream, the name of which was unfortunately not known to $\mathrm{my}$ informant, and it ap- 
pears that he had it on his right to within three marches of Noorpoor, where he crossed it and left it running off to his left: in his last march to Noorpoor from Bussaul, he crossed the Ravee, which he said was thereabout the size of the stream he left three marches back. It appears more than probable that this stream was the Ravee, but he did not know it as such at the point he left; and as he left it to his left, it must have either gone to the Beyas or Ravee, but I think the latter is almost certain, and that it has taken a curve in the hills for these two marches, and come round to the right to the point at which he crossed it, for he says it ran from his left to right, which would agree, and I have in consequence given it this curve, and made it the Ravee, or at all events its most distant branch. This route also proves to me that the Chunab does not come from the northward of the snowy ridge, because this route must have crossed it if it did; but this is supposing the only route I lave got by this road to be correct, which may not of course be the case; and without a second to corroborate this, I would not consider this as certain, though $I$ have every reason to suppose this route correct, for it agrees with others from Noorpoor downward.

THE BEYAH, OR BEYAS (HYPHASIS).

THis river measured, at Bhirowal Ghat, seven hundred and forty yards. Its right bank is very high, and its current very rapid. The day we reached it, it was at its greatest height, and so rapid that the boats could not make the left bank. Some were carried down six or seven coss in attempting it; it, however, fell the next day. It is fordable in most places in the cold season, but its bed contains many quicksands, and at this season there are many islands and sand-beds formed towards its centre. There are twenty-five boats at this Ghat and its vicinity, but they are very bad for the rainy season. They are made of flat planks, more like rafts than boats, with a plank of one foot all round, and do not draw six inches water when filled. There is but little wood along the banks of this river; what there is is small. It 
joins the Sutluj eighteen coss below Bhirowal, near the village of Hurake, not far from Feroozpoor; after their junction the joint streams are called Beas, and afterwards called Gharra, but from what point I know not. It is called the Gharra at Gordeean Ghat near Pakputtun, a hundred coss above Bahawulpoor. They join the Chunab above Ooch, as has been mentioned, thirty-two coss below Bahawulpoor, and fifty-eight from Moultaun. The Beyas and Sutluj are nearly the same size, but the Beyas is rather the largest. Their course, too, is nearly the sane from the snowy ridge, a hundred and fifty miles to their junction, and two hundred and sixty more to their junction with the Chunab or joint streams of the Jelum, Chunab, and Ravee. Wood is to be got in abundance from the hills not far distant. The Beyas Gunga and Ball Gunga form the Beyas, the former passing Kot Kangra to the southward, and the latter to the northward in a westerly direction near and joining at Hureepoor, below the fort, one march. The Ban Gunga separates into two branches near the fort, and a branch passing on each side of it, they form an island and join immediately below it.

\section{THE RIVERS OF KHORASSAN.}

THE HIRMUND OF HELBUND.

'THIS river is the greatest of the Khorassan rivers. It rises west of Caubul in the hill called Kohi Baba. Its course is south-west through the Huzarah country, and passing to the southward, it crosses the great roads from Kandahar to Heraut at Greeshl, a distance of two hundred and sixty miles. The whole distance to within two marches of this is through very high and difficult hills. From this to where it falls into the lake of Seestaun is one hundred miles, total three hundred and sixty miles. In the hot season, when the snow melts, it is a very large river, and it is a common practice with the people of Greeshk to try to shout arrows across or sling stones, but it is not to be done. In the cold weather it is nearly breast deep, equal to the Kamma river at Akora. There are 
two boats at the Greeshk Ghat, but it is fordable for the greatest part of the year; it receives considerable streams in its course. It is joined fourteen miles above Greeshk by a stream whose course is eighty miles, which rises to the south of the Huzarah country at Seahbund. It also receives the Urghundab five coss below Greeshk, and part of the Turnuk; it is also joined by the Kashrood at Kohnisheen further down.

\section{THE URGHUNDAB RIVER}

RISES in the Huzarah hills about eighty miles north-east by north of Kandahar, passes within five coss of the town to the north and west of it, and joins the Hirmund five coss below Greeshk on its left bank, after a course of one hundred and fifty miles. In the cold season this river is two and a half or three feet deep, and fifty yards broad; but in the hot weather, when the snow melts in the hills, it is not fordable for three months, being excessively rapid, and at this season above one hundred and fifty yards broad.

\section{THE INHASHROOD.}

This river rises at Sakkir about ninety miles south-east by soutl of Heraut, and after a course of one hundred and fifty miles joins the Hirmund at Konisheen on its right bank. It is larger than the Urghundab and smaller than the Hirmund; its depth in the cold season is up to a man's hip (three feet), and fifty or sixty yards broad: it is not fordable when the snow melts, is crossed on mussulss or leathern bags, and small rafts made of wood and reeds. Its breadth in the hot season is from one hundred and fifty to one hundred and seventyfive yards, and very rapid; it also crosses the great road from Kandahar to Heraut near Dilaram.

THE TURNUK.

ThIs is a small stream, rises at Mookr, and after a westsouth-west course of two hundred miles, joins the Urghundab near Doaba; in the cold season, however, its water runs 
into a long lake near Dehi Gholaman, called the Doree, which has been taken for a river. When the Turnuk rises the superfluous water runs to the Urghundab : in the cold season it is knee deep, and it seldom rises above a man's middle.

\section{THE FURRAHROOD}

Is larger than any of these rivers, excepting the Hirmund. It is in the cold season above a man's hip, and from fifty to sixty yards broad; in the hot weather it is crossed on mussuks and rafts of wood and reeds. It is at this season very rapid; it rises south of Pursee, and is joined above Furrah and below Guranee by the Jizeea Rood. It falls into the lake of Seestaun at the north-west angle, after a course of two hundred miles. It appears wonderful that this lake should receive so many rivers without any apparent vent for the water; and it is stated not to be above thirty or thirty-five coss across at the broadest part.

\section{THE POOLIMALAN OR HERAUT RIVER.}

This river rises near Oba (east of Heraut) in the Ymak country, and receives three or four streams before it reaches Heraut. It is a small river in the cold season, but rises to a considerable size when the snow melts. The greater part of its water is expended in the vicinity of Heraut on the cultivation; two or three canals are cut from it, and pass through the town. There is a bridge across it three coss south of the town. It appears, from a route from Mour to Mushhud, that a river was crossed half-way, running from left to right, called the Tejun; and the routes from Heraut to Mushhud go along its banks by the north road as far as Kafir Kila, where it is left running to the north or right. This can be no other than the one which is crossed in the other route half-way between Mour and Mushhud; but where it runs to after that I know not. I think Arrowrsmith's map has it perfectly correct. Mr. Forster's route seems to have led Rennel into an error, in making it run south into the lake of Seestaun; but this rivulet. which $\mathrm{Mr}$. Forster crossed, running south, does not appear to be the Heraut river, but a small stream which 
comes from the hills, which separate the north and south roads to Mushhud, and must be lost to the southward, for it appears by several accounts that no stream is crossed from Furrah to Ghain and Toon, or from Jellallabad to ${ }^{2} \mathrm{Nih}$, excepting the Furrahrood; but if the Heraut river ran into the lake of Seestaun, it must have been crossed in both these routes, $*$

* I omit Mr. Macartney's account of the desarts; one of them is fully described in ny nurrative, and the other in Mr. Kinnier's Geograply of Persia. The account of the desarts is followed by descriptions of the different kingdoms and provinces replesented in the map, which are seldom purely geographical, and which need not therefore be repeated. 


\section{APPENDIX E.}

PUSHTOO VOCABULARY.

The words are here spelt according to Dr. Gilchrist's method; $Q$ stand for a guttural $K$, the rest has been explained in the Preface. The first column contains Pushtoo words in the Western dialect, and the second in the Eastern.

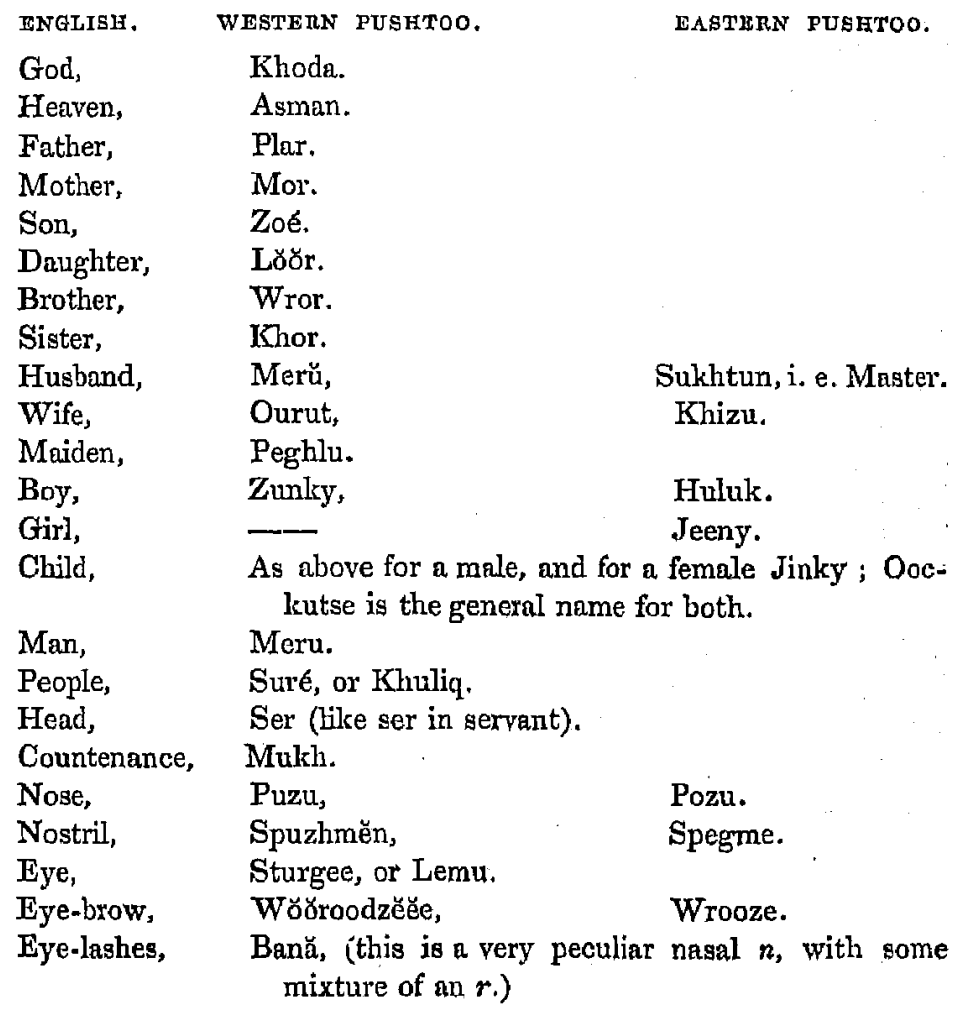
mixture of an $r$.) 


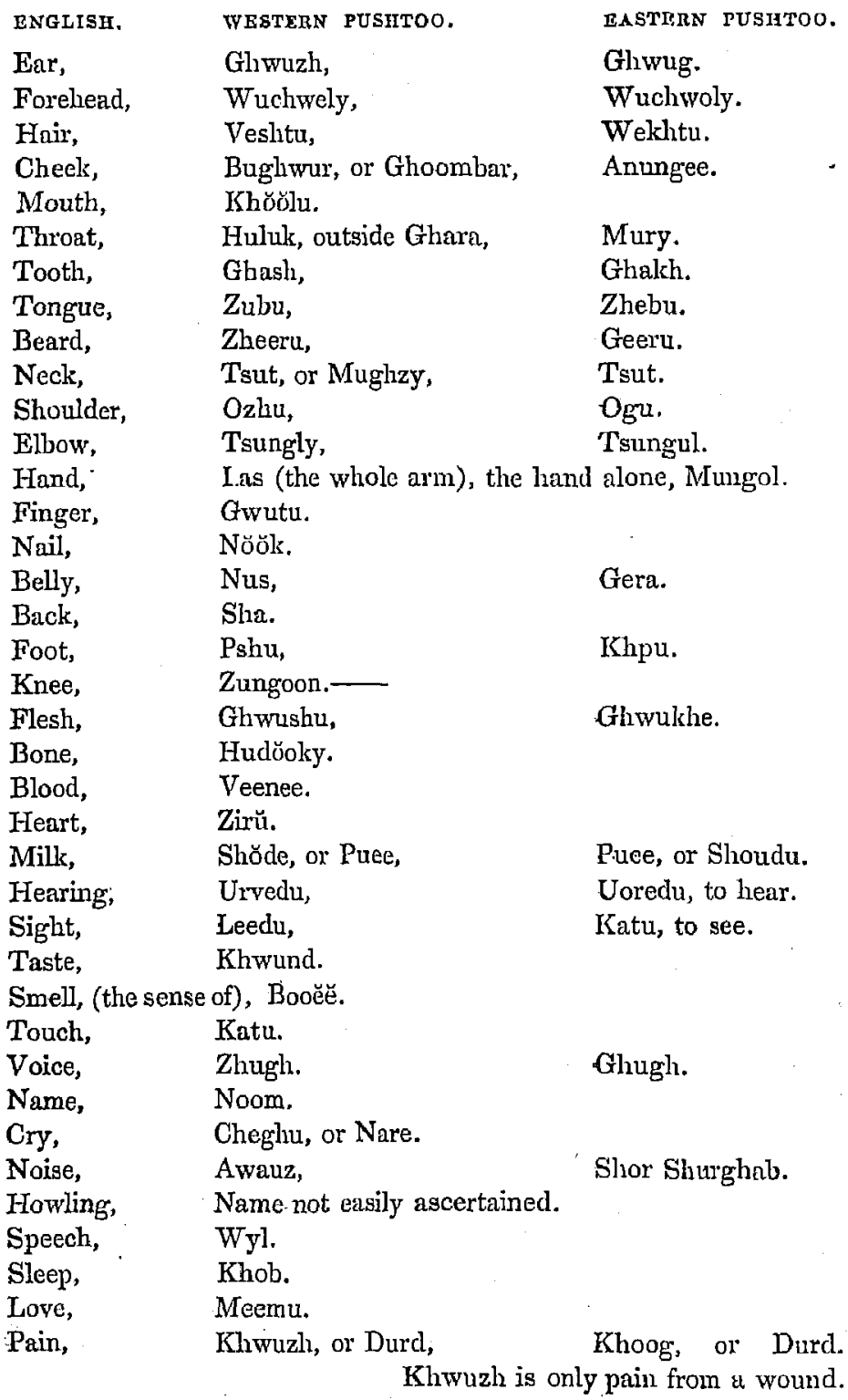


ENGL1SH.

Trouble,

Labour,

Force,

Power,

Marriage,

Wedding,

Life,

Size,

Spirit (or mind), Urwall, sa (breath).

Deatl,

Cold,

Circle,

Ball,

Sun,

Moon,

Star,

Ray,

Wind,

Whirlwind,

Tempest,

Rain,

Hail,

Lightning,

Snow,

Ice,

Day,

Night,

Morning,

Evening,

Summer,

Spring,

Autumn;

Winter,

Year,

Time,

Earth,

Water,

Sea,

River,

VOL. II.

WESTERN PUSHTOO.

Khupagee,

Khwaree.

Koowut.

Zoor.

Kaveen,

Wada; or Wra.

Zhwundoon.

Qudur.

Murg.

Saru, Yulch.

Kirshu, or Daeru,

Nmur,

Spozhmy,

Storce. Bad.

Boorbooky,

Seelý.

Baran.

Gulý.

Breshnu,

Wnora.

Yulkh.

Rwudz.

Shpu.

Suba,

Masham,

Doby,

Psurly.

Muny.

Zumy,

Kal.

Wuqt.

Mzuku,

Obu.

Derea.

Rod,
Gaty. Metal ball for a gun,

Not easily ascertained, Brekhnu, a flash; Lumbu, a flame; Pulwushu, a spark.
Zuheeregee.

Nika.

Kirkhu, or Daeru.

Golee.

Nwur.

Spogmy.
EASTERN PUSHTOO.

Brelihnu.

Boorbooruky.

Selier.

Makham.

Ory.

Zhumy.

Zmuku.

Seen. 


\begin{tabular}{|c|c|c|}
\hline & 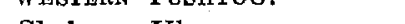 & \\
\hline Wave; & Chang & \\
\hline Sand, & Shypon. & \\
\hline Dust, & Doŏree. & \\
\hline Mud, & Khutu. & \\
\hline Mountain, & Ghur. & \\
\hline Coast, & Gharu. & \\
\hline Rising ground, & Ghoondy. & \\
\hline Valley, & Dura. & \\
\hline Vapour, & Lură. & \\
\hline Fire, & Or. & \\
\hline Heat, & Gurmee. & \\
\hline Depth. & Zhuwur. & \\
\hline Height, & Lrour, & Oochut. \\
\hline Breadth, & Plun wale, & (Plun broad). \\
\hline Length, & Oozdwale (Oozhd, long), & Oognod Walee. \\
\hline Hole, & Soory. & \\
\hline Ditch, & Khunduk. & \\
\hline Stone, & Kane. & \\
\hline Gold, & Sŏorre Zer, Red Gold. & \\
\hline Silver, & Speen Zer, White Gold (zer & as ser in servant). \\
\hline Salt, & Malgu, & \\
\hline Forest, & Zungul. & \\
\hline Herb, & Washu, & Wukhu. \\
\hline Tree, & Wunu. & \\
\hline A stake, & Muozhy, & Muogy. \\
\hline Verdure, & Sheerwalee. & \\
\hline One, & Yuo. & .. \\
\hline Two, & Dwu. & \\
\hline Three, & Dre. & \\
\hline Four, & Tsulor. & \\
\hline Five, & Pinza. & . \\
\hline Six, & Spuzh. & \\
\hline Seven, & Owu. & \\
\hline Eight, & Utu. & \\
\hline Nine, & Nuh. & \\
\hline Ten, & Lus. & . \\
\hline Eleven, & Yuolus. & \\
\hline Twenty, & Shil. & \\
\hline Thirty, & Dersh. & \\
\hline
\end{tabular}




\section{VNGLISH.} WISTERN PUSHTOO. EASTLRN PUSHTOO.

One hundred, Sel (as to sell).

One thousand, Zir.

First, Awwul.

Second, Doyum.

Third, Dreum.

Fourth, Tsulorum.

Twentietll, Shilum.

I, $\mathrm{Zu}$.

Thou, $\mathrm{Tu}$.

He, she, it, Hughu. $\mathrm{We}$, You, They, Above, Moozhu, Tase.

Moongu.

Below,

Before,

Behind, Upon,

Of, Hughudee.

Portu.

Kshutu.

Wrande,

Oorande.

Wroostu, Ooroosty.

Pur, or $\mathrm{Pu}$, with Bande, or Du Pasu affixed, Pu Lar Bande on the rood.

From,

By,

This, Du.

That,

Lu.

Du Lu (lit. of from).

Da or Dugha.

If, Hugha.

Unless,

Yet,

Still,

Ki.

Ku nu (if not).

Tirosee (used for but, bare).

'Though, Turosee.

But, Iu tsu.

Without, Wule.

And,

Be.

Since,

0 .

Since, Chu (as). (in time). See Hugha Wuqta.

Notwithstanding, Bawujoodee.

Nevertheless, Tu Hugha Pore.

Except, Be lu.

Because, Pu lugha Subub.

Therefore, Ditto, ditto.

Then, Hugha Wuqt. 
ENGLISH :

There,

In,

With,

Through,

To,

Till,

About,

Over,

Much,

Nearly,

Under,

More,

Most,

Very,

Perhaps,

Rather,

Once,

Twice,

Only,

Alone,

Yes,

No,

Who,

What,

Where,

When,

Which,

To be,

'To have,

I will,

I ought,

1 may,

$I$ can,

I wish,

To wallk,

'To run,

To ride,

To stand,

To fall,

To lie down,
WESTERN DUSHTOO.

Hugha Zae.

$\mathrm{Pu}, \mathrm{Kshe}$

Suru.

Pore.

Luru,

Tur.

Gurd-Wuxd, Chaper.

Du Pasu.

Der.

Nizde.

Lande.

Zeeat.

Zeeat, hee.

Der.

Kuvee, Sliayud.

Oorande.

Yuw zila or yuw Waree.

Dwu zila or clwa Waree.

Hoom.

Yuwaze.

Ho.

$\mathrm{Nu}$.

Tsok? relative Tse or Che.

Tse.

Chere,

Chirta.

Kula.

Koom.

Wuswa.

Lurul,

Not to be had separate (I will do, Zu Wokrumu).

Pu ma bande, Lazim de.

$\mathrm{Zu}$ Shumu.

Zu Shumu.

$\mathrm{Zu}$ Ghwarum.

'Tlu.

Zghukhtu.

Soore du.

Woodrectu.

Lwedu,

Prewabu.
BASTELN PUSHTOO.

Pu-ke.

$\mathrm{Su}$ (affixed).

Moólistu. 
ENGLIST.

To eat,

To drink,

To fight,

A horse,

A cow,

A bull,

A bufíalo,

A cock,

A hen,

A tiger,

A serpent,

A sheep,

A bird,

A fish,

A panther,

A camel,

An elephant,

A ship,

A boat,

A sail,

An oar,

A sailor,

A commander of

$$
\text { a vessel, }
$$

A soldier, An officer,

Cotton,

Silk,

Wool,

Siclnness,

Health,

A sword,

A loom,

A saw,

A shoe,

$A$ bed,

A house,

A cloor,
WESTERN PUSHTOO,

Khwaru.

Tishu,

Jungedu, Jung kuwul.

As.

Ghwa.

Gliwae.

Meshu.

Chirg.

Chirgu.

Zmurry.

Mar.

Meeozh (a Doombr), Hure

(a common sheep),

Murgha.

Mahee.

Prang.

Oosh,

Peel hutte,

Jahaz.

Bery.

Badban.

Chupa.

Mangy, Muhana.

Nakhooda.

Spahee.

Sirdar, Khan.

Kalulkee (uncleaned), Poombeh (cleaned),

Reshum,

Ghwure.

$\mathrm{Na}$ Raghgee, Na Jorteea.

Jorusht,

Tooru.

Makoo.

Urru.

Kupy.

Kut.

Khooneh, Kor.

Derwazu, War.
RASTERN PUSHTOO.

Șku.

Moozurru.

Gịde.

Oolkh.
Şehut:

Punne.
Malooch (uncleaned).

Poombeh (cleaned).

Relkhum. 
ENGLISH.

A nail,

A hammer,

A linife,

An island,

Rice,

Wheat,

Hay,

Arrack,

Opium,

Bang,

A tailor,

A weaver,

A carpenter,

A smith,

A labourer in husbandry,

A rock,

A cave,

A shadow,

Far,

Near,

Beside,

Beyond,

Town,

Field,

Root,

Bread,

Pepper,

Oil,

Eggs,

White,

Black,

Red,

Green,

Yellow,

Blue,

Brown,

Iron,

Lead,
WESTERN PUSHTOO.

Mekhtubilu,

Melkhchoo,

(Large) Charu (small) Choorby.

Juzeeru.

Shole (the plant) Ooreezliu, Ooreja (the gum).

Ghunum.

Bedu,

Shrab.

Turiak.

Bung.

Khyat.

Jolah.

Duroozgur.

Push, Ahingur.

in

Dehgan.

Loe Dubber (a large stone), Loe Ghut.

Ghar.

Sore.

Lere.

Nizde,

Nizlide.

Du Chungy. As " Du Wunne du Chungy" (beside the tree).

Pu Hugha Khwa,

Sheher,

Pore Pulu.

Kur.

Belsh,

Mury,

Mircl.

Ghoru.

Hugy.

Speen.

Tor.

Siru or Soor.

Zerghoon.

Zhir.

Sheen.

Oode.

Ospunu,

Soorp, Seeka.
EASTERN PUSHTOO.

Melkh.

Dubuly.

Puslikula. 
ENGIISH.

Tin,

Stranger,

Friend,

Enemy,

To buy,

To sell,

To boirow,

To lend,

Anger,

Pity,

Rich,

Poor,

Revenge,

Forgiveness,

Hunger,

Thirst,

A branch,

A leaf,

A flower,

Earth,

Hard,

Soft,

Quick,

Slow,

Weakness,

Strength,

To move,

To rest,

To fly,

To swim,

To sink,

To seek,

To find,

To leal,

To kill,

Wisdom,

Power,

Goodness,

Creation,

Providence,
WESTERN PUSHTOO,

easterN pughtoo.

Qulue,

Purdy, Prudy.

Yax.

Dushmun,

Peerodu, Ranewo.

Khursuwul,

Por Aklistul.

Por Wurkwwul.

Quhr, Ghosu.

Zirŭ Swy (heart-burning).

Doorujadar, Doulutmund.

Khwar, Nest-mund.

Keenu, Boghuz (the quality), Budlu (the act).

Bukhshuna, Bukhuna.

Lwuzhu,

Tundu.

Shalkh,

Paně.

Gwul.

Khwoore, Khuvoree (ground-lkhalk).

KJuk, Sukht.

Post or Pasteh.

Zir.

Wro, Krar,

Kumzoree.

Zor.

Khwuzedu.

Pate Kedu.

Aloowatu.

Lambowuluul.

Doobedu.

Katu (to look for).

Mindu.

Moondu.

Jorawul.

Ghwuzhlu.

Hoosheearee,

Hookheearee.

Qoodrut.

Kheguru.

Pydash,

'Tugdeer,
Loga.

Khakh.

Ro.
Khurtsuwul. 
ENGLISH.

Temple,

Sacrifice,

Priest,

Pilgrimage,

Government,

King,

Minister,

General,

Judge,

Law,

Right,

Justice,

Punishment,

Theft,

Murder,

Rebellion,

War,

Peace,

Honesty,

Humanity,

Charity,

Avarice,

Generosity,

Virtue,

Vice,

Understanding, Puhm, Pozhu.

Will,

Certainty,

Doubt,

Assent,

Belief,

Koorbanee.

Huj. Zeearut.

Hakimee.

Sirdar.

Qazee.

Sluura.

Hug.

Insaf.

Tazeer.

Ghulu.

Jung.

Rogha.

Deeanut.

Sureetob.

Sukhee tob.

Tumu.

Zilmee tob.

Nekee.

Budee.

Murzee.

Yekeenee.

Shuk.

Bawur.
WESTERN PUSHTOO.

Musjid, Joomaet (of idols), Boot Khaneh.

Mǒŏlla, Imam.

Shah, Badshah

Wuzeer, Saheb-kar (prime minister).

Ghwuzhlu, Qutul.

Yaghee Geeree.

Munil, Qubool Awul.

THE END. 



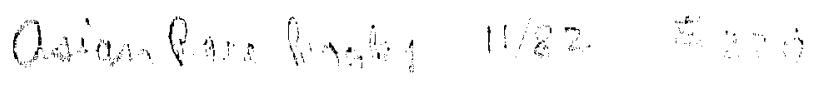


005020940 